Portland State University

PDXScholar

Summer 7-25-2013

\title{
Social-Ecological Dynamics of Coral Reef Resource Use and Management
}

Sarah J. Freed

Portland State University

Follow this and additional works at: https://pdxscholar.library.pdx.edu/open_access_etds

Part of the Natural Resources and Conservation Commons, Natural Resources Management and Policy Commons, and the Oceanography Commons

Let us know how access to this document benefits you.

\section{Recommended Citation}

Freed, Sarah J., "Social-Ecological Dynamics of Coral Reef Resource Use and Management" (2013). Dissertations and Theses. Paper 1106.

https://doi.org/10.15760/etd.1106

This Dissertation is brought to you for free and open access. It has been accepted for inclusion in Dissertations and Theses by an authorized administrator of PDXScholar. Please contact us if we can make this document more accessible: pdxscholar@pdx.edu. 
Social-Ecological Dynamics of Coral Reef Resource Use and Management

by

Sarah J. Freed

A dissertation submitted in partial fulfillment of the requirements for the degree of

\author{
Doctor of Philosophy \\ in \\ Environmental Sciences and Resources
}

Dissertation Committee:

Elise F. Granek, Chair

Darrell Brown

Veronica Dujon

Yangdong Pan

J. Alan Yeakley

Portland State University

2013 
(C) Sarah J. Freed 


\begin{abstract}
This dissertation investigates social and ecological factors that facilitate effective management of coral reefs as social-ecological systems. Meta-analytical and field-based methods were employed to examine current management challenges and identify strategies that improve management effectiveness and coral reef health. A meta-analysis was used to evaluate biological indicators of reef health in relation to the types of fishing regulations in place (no-take areas, gear restriction areas, and periodic closures) and the actor groups (community-based, co-management, state, private) involved in management efforts for coral reef fisheries throughout the world. Other than enhancement of fish biomass within no-take areas that was significantly greater than in gear restriction areas, most biological indicators benefitted similarly from management techniques of no-take areas and gear restriction areas. Community-based and co-management were the best performing management arrangements for some biological outcomes but require further case studies to verify findings. Investigation of management effects by region indicated that previously degraded reefs received fewer benefits from management implementation than did relatively healthier reefs. For field investigations, the Comoros islands in the Western Indian Ocean served as a model for tropical coral reefs with challenging socioeconomic contexts, high biodiversity, and high vulnerability to coral reef degradation. Empirical study at 21 sites was used to identify the relative effects of natural and anthropogenic threats to coral reefs of the Comoros. Most previous studies of reef health focus on primarily natural factors or a single anthropogenic threat. This study examined suites of natural factors and human activities to identify the relative
\end{abstract}


importance of each on reef health. Human activities including fishing, sand extraction, and beachfront housing and development were the best predictors of reef health status. Most notably, human population and fishing predicted fish richness, abundance, and biomass with seasonal variation in the effects, while site orientation strongly predicted benthic cover. Field studies in the Comoros were also used to investigate the roles of community and state actors in co-management and compare effectiveness of comanagement across sites with varying levels of actor participation. Effective management was found to occur with community or 'meta-community' (in this case, a Marine Protected Area in which the efforts of several communities were organized) participation in governance and support of state or external agents, while resilient management that overcame considerable challenges was found to occur only with strong community participation and leadership in governance. External agents were found to contribute to development of meta-community governance structure and initiation of community participation through education and capacity building. The findings from these studies reveal that coral reef management can be improved through context appropriate regulations that address detrimental human activities and through wide acceptance and participation in governance with cooperation among states, communities, and external agents. 
Dedicated to the memory of Choo Chee Kuang 


\section{Acknowledgments}

I gratefully acknowledge the efforts of everyone who helped me to complete this dissertation. My advisor Elise Granek and committee members Yangdong Pan, Veronica Dujon, Darrell Brown, and Alan Yeakley. Field assistants Mmadi Ahamada, Ahmed Ali, Ahmed Dhalane, David Gibbs, Zaharani Moindjie, Jaffar Mouhhidine, Kader Mouhhidine, Jane Nurse, Kristen Omori, Hamada Youssoufi, and community participants who made this research possible. Said Ahamada for his collaboration and insight in development of field research methods. My family who supported me throughout this work. National Geographic Conservation Trust, the National Science Foundation's Graduate Research Fellowship Program, and SeaWorld Busch Gardens for providing funding. 
Table of Contents

Abstract ..........

Chapter 2

Global comparison of biological outcomes across coral reef fishery management

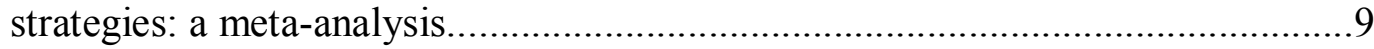

Chapter 3

Local anthropogenic impacts on the world's most vulnerable reefs: A case study of the Comoros.

\section{Chapter 4}

Effective co-management through community and meta-community roles in coral reef fishery management in the Comoros..

Chapter 5

Conclusion.

References.

Appendices
A. Meta-analysis data $\&$ forest plots. 148

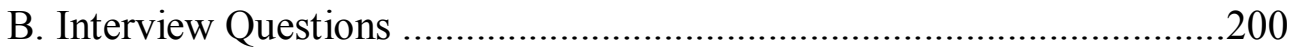
C. Human Subjects Approval ............................................................209 
List of Tables

Table 2.1. Search terms used in Web Of Knowledge..............................27

Table 2.2. Number of cases in meta-analyses of biological outcomes by management

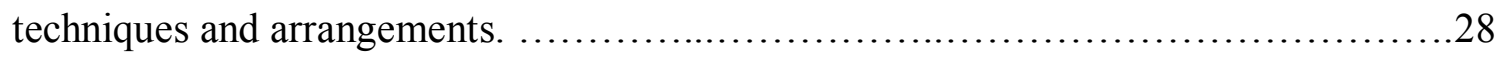

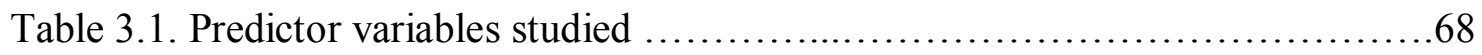

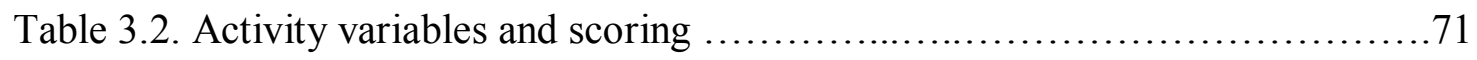

Table 4.1. Governance attributes and institutional performance by site..............115

Table 4.2. Ecological outcomes by site. ..................................116

Table 4.3. Perceptions by site. ............................................. 117 


\section{List of Figures}

Figure 1.1. Map of coral reefs classified by present integrated threats from local activities

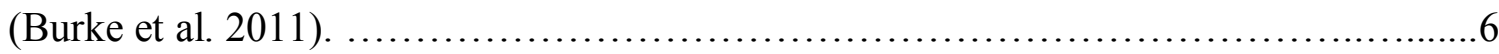

Figure 1.2. Map of countries classified by social and economic dependence on coral reefs (Burke et al. 2011).

Figure 1.3. Map of Marine Protected Areas in coral reef regions classified according to management effectiveness rating. (Burke et al. 2011). ................................

Figure 2.1 Meta-Analysis results by management technique.........................29

Figure 2.2 Mean response ratios of coral richness by management technique.............30

Figure 2.3 Mean response ratios of catch per unit effort (CPUE) by management

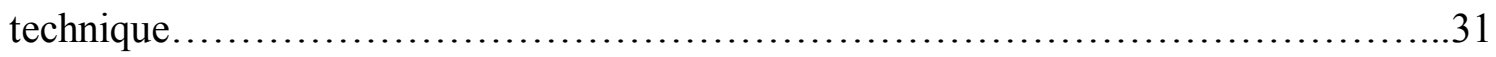

Fig. 2.4 Meta-Analysis results for management techniques by region...................32

Figure 2.5. Meta-Analysis results for management actor groups.......................33

Figure 2.6 Detection of publication bias in meta-analysis. .............................34

Figure 3.1. Seasonal changes in fish abundance, biomass, and richness...............72

Figure 3.2. RDA plot (distance triplot) of reef health variables with respect to predictor

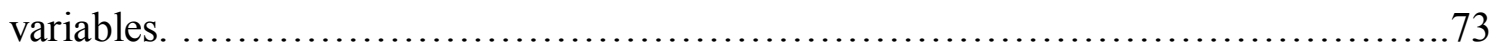

Figure 3.3. Proportion of variance explained for RDA plot..........................74

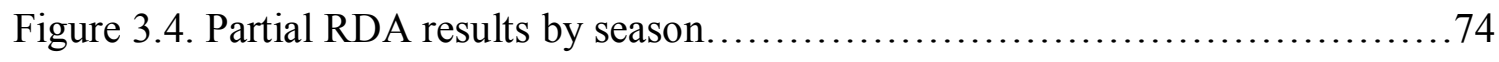

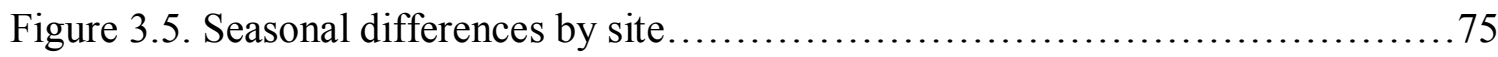

Figure 4.1. Illustration of a spectrum of co-management arrangements...............113 
Figure 4.2. The Comoros. 
Chapter 1. Introduction

'We don't seem to manage fish as much as we manage people'

(Voiland and Duttweiler 1984)

Humans both depend on the earth and have a profound impact on it, causing more change in the last 50 years than any previous comparable period (Millennium Ecosystem Assessment 2005). Some of the most notable changes to marine systems include loss of $20 \%$ of the world's coral reefs, creation of "dead zones" in coastal waters, and collapse of fisheries (Millennium Ecosystem Assessment 2005). Human impacts are well known to affect coral reefs: $60 \%$ of the world's coral reefs are directly impacted by human activity and with inclusion of rising sea temperature, $75 \%$ of reefs are affected by humans (Burke et al. 2011; Fig.1.1), and it is unlikely that any "pristine" reefs remain (Hughes et al. 2003; Pandolfi et al. 2003; Gardner et al. 2003).

Management is needed to reconcile human activities and resource use with maintenance of reef ecosystem functions and services from which around 850million people benefit (Burke et al. 2011; Fig.1.2). Management has been implemented in many forms and has produced a variety of outcomes, often ones that were unintended and undesired. The frequency of management failures and resource crises has given rise to changes in management paradigms since the 1970s (Berkes and Folke 1998). For coral reefs, effective management is known to occur in only $15 \%$ of sites with known Marine Protected Area (MPA) status, effectively protecting $6 \%$ of the world's reefs from 
overfishing (Burke et al. 2011; Fig.1.3). Much work remains to identify and implement effective and enduring management practices.

Thorough understanding of an ecosystem does not guarantee management success. The ecological features required for maintaining coral reefs are well described in studies of reef resilience. Diversity of coral colonies maintains resilience of the reef to physical disturbance (Connell et al. 1997) such as storms, erosion, sedimentation, and sea temperature change. Diversity of coral and other habitat forming organisms on reefs facilitate diversity of fish (Sale 1977; Steneck 1988) and other organisms in coral reef communities. The diversity of benthic cover, especially presence of crustose coralline algae and a low relative abundance of fleshy macroalgae, ensures that coral recruits will find places to settle on the reef (Miller and Hay 1996; Steneck 1988). Fish functional group and species diversity help maintain reef resilience. Predators control lower trophic level populations, including herbivores and bioeroders (Hughes 1994; McClanahan et al.1994). Herbivores in turn control plant growth (such as macroalgae and turf algae) on the reef to allow for coral recruitment (Mumby et al. 2007), which is essential to reef recovery from disturbance (Hughes 1994). While this detailed knowledge clearly describes what is required in a healthy reef system, it remains difficult to determine when action must be taken to conserve a reef (Bellwood et al. 2004) and what action will be most effective. Detailed knowledge of factors impacting the reef is needed to prioritize management efforts.

Coral reefs have been demonstrated to recover fairly well from natural disturbance (Connell et al. 1997) but their ability to do so is stunted by human pressures (Hughes 1994). Fishing is well studied and has been clearly documented to not only 
affect fish abundance, average size, diversity, and biomass, but also the abundance and proportion of coral and algal covers (Lester et al. 2009; Mumby and Harborne 2010). Fishing is the most widespread reef-impacting activity and is often conducted in a manner harmful to reef health, through over-fishing or use of methods that destroy reef habitat (Burke et al. 2011; Newton et al. 2007; Fox and Caldwell 2006). Fishing, however, is only one of many threats to reefs. Coastal development, pollution from terrestrial and marine sources, and damage from ships are other top threats to reefs (Wilkinson 2004; Burke et al. 2011). The small fraction of reefs studied and even smaller fraction monitored over time means that few activities affecting reefs have been studied in depth and that we know little about the impact of many activities and of the greatest threats on particular reefs (Burke et al. 2011). In addition, understanding of social context, such as dependence on reef resources for subsistence and livelihoods and alternative income sources, is needed to ensure effective management.

Management of interconnected social-ecological systems is a challenging undertaking that requires work across multiple disciplines and scales (Liu et al. 2007). It also requires a "people-oriented approach" (Berkes and Folke 1998) focusing on human activities and behavior and allowing for natural variation in ecosystems, rather than trying to "command and control" the ecosystem with often disastrous results (Holling and Meffe 1996). A variety of management strategies have been developed and implemented in coral reef systems. MPAs and marine reserves are widely promoted strategies for coral reef management and have been demonstrated to improve or at least maintain ecological status (Lester et al. 2009; Selig and Bruno 2010), but can have adverse social outcomes (Alder 1996; Christie 2004). Without social benefits and widespread approval by 
stakeholders, management is likely to be ineffective and short-lived (Alder 1996; McClanahan 1999; Mascia 2003). Such management failures are rarely documented, but are likely to occur widely and are beginning to be recognized in terrestrial protected areas throughout the world (Mascia and Pailler 2011), as well as in regions where MPAs have been implemented for coral reef protection, such as in the Indian Ocean (McClanahan 1999; McClanahan et al. 2005). Another study of the Indian Ocean region found improvements in fish biomass within managed (fishery closures) areas and lowest fish biomass in unprotected areas where there was intermediate economic development, thus emphasizing the need for an integrated approach of ecological conservation, socioeconomic development, and poverty reduction to achieve sustainable coral reef fisheries (Cinner et al. 2009). Other management strategies are also sensitive to social context. Traditional management has provided effective conservation in many locales for hundreds of years, but more recent experiences suggest that traditional management practices are less effective when faced with population growth and socio-economic changes (Cinner and Aswani 2007; Cinner et al. 2007). A study in Papua New Guinea revealed population and modernization "thresholds" beyond which customary fishing area closures were not utilized as strategies for fisheries management (Cinner et al. 2007). The question remains how management can successfully address social context as well as maintain ecological functions and services.

The following chapters address the question of how to improve management in of coral reef social-ecological systems. The findings in each chapter provide answers to a particular knowledge gap in our current understanding of coral reef management. Chapter two investigates the outcomes of management strategies for coral reef fisheries 
throughout the world, with the goal of identifying the relative effectiveness of various management approaches and the considerations that may be necessary when working in a particular context. The following chapters look at management in a field setting as a model for tropical coral reefs with challenging socioeconomic contexts, high biodiversity, and highly vulnerable coral reefs. Chapter three evaluates the threats to reefs of the Comoros and the relative importance of anthropogenic and natural factors on reef health, a novel approach to evaluating impacts on coral reefs, with the goal of identifying the most time and resource effective management targets to protect the reefs. Chapter four evaluates the roles of community and state actors in ensuring effective co-management at sites throughout the Comoros, with the goal of furthering understanding of comanagement and identifying management strategies that appropriately utilize human resources and achieve greatest effectiveness. Keeping in mind that the decisions and actions of managers and resource users are the most important ways to 'manage' a resource or ecosystem, the findings in the following chapters can be directly applied to the field setting of the Comoros and to similar coral reef systems in developing nations.

This work can inform wider tropical marine ecosystem management efforts and contribute to the body of knowledge and future directions for coral reef management study. Integration of social and ecological findings improves upon the separate treatment of social and ecological aspects currently found in the majority of coral reef management literature. Focus on management of reefs with high biodiversity and vulnerability to degradation provides insight that is greatly needed for management practices. The following chapters provide key information that will greatly advance coral reef management knowledge and practice. 


\section{REEFS AT RISK}

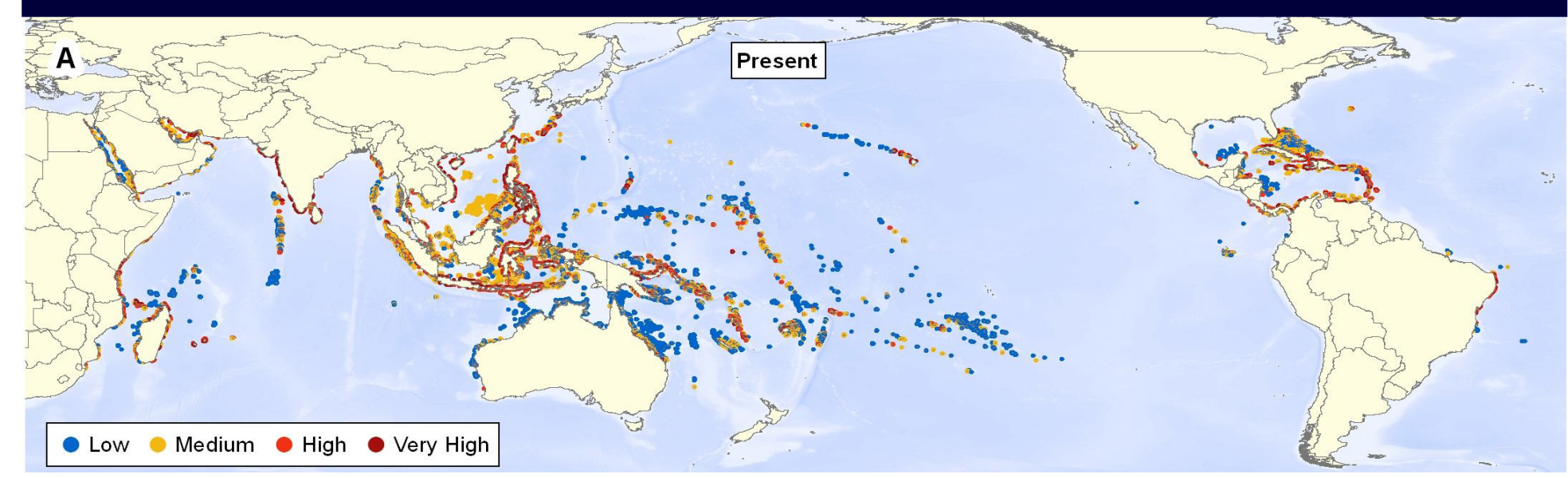

WRI Reefs at Risk

Figure 1.1. Map of coral reefs classified by level of integrated threats from local activities (Burke et al. 2011). 


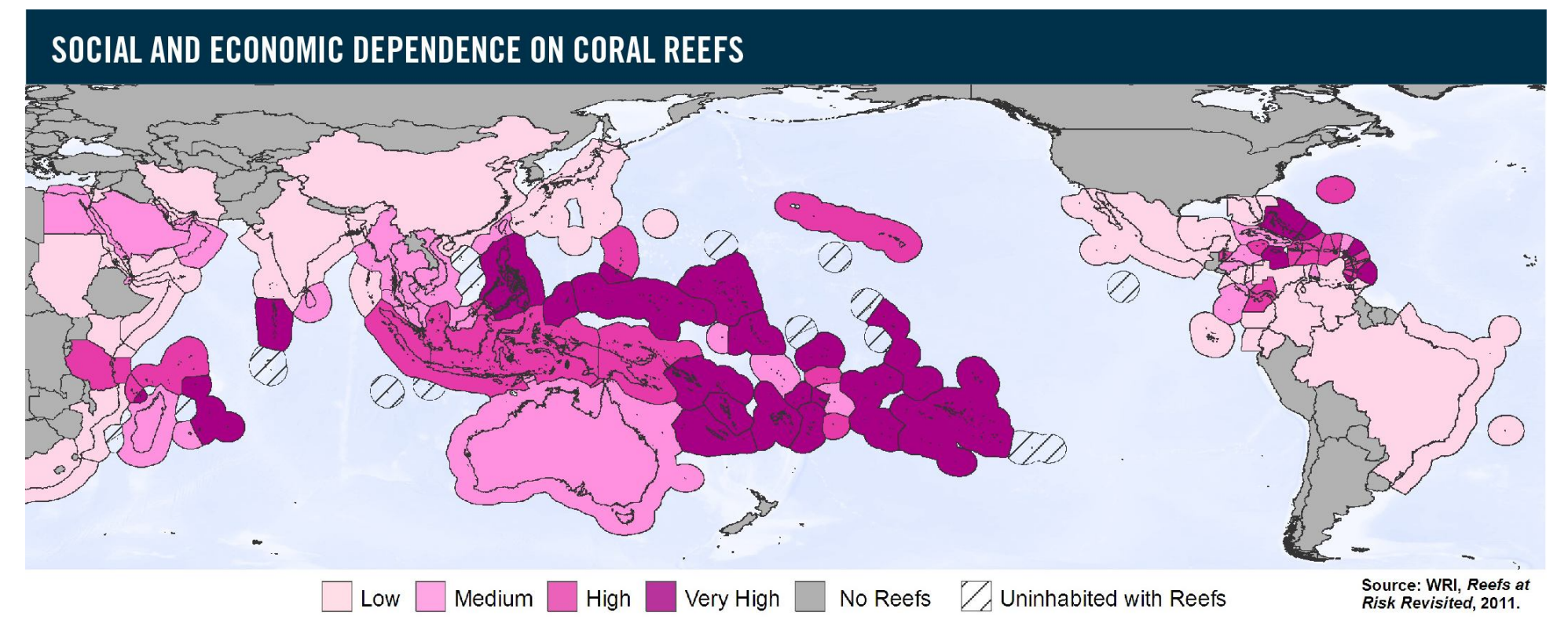

Figure 1.2. Map of countries classified by social and economic dependence on coral reefs (Burke et al. 2011). 
MARINE PROTECTED AREAS IN CORAL REEF REgIONS CLASSIFIED ACCORDING TO MANAGEMENT EFFECTIVENESS RATING

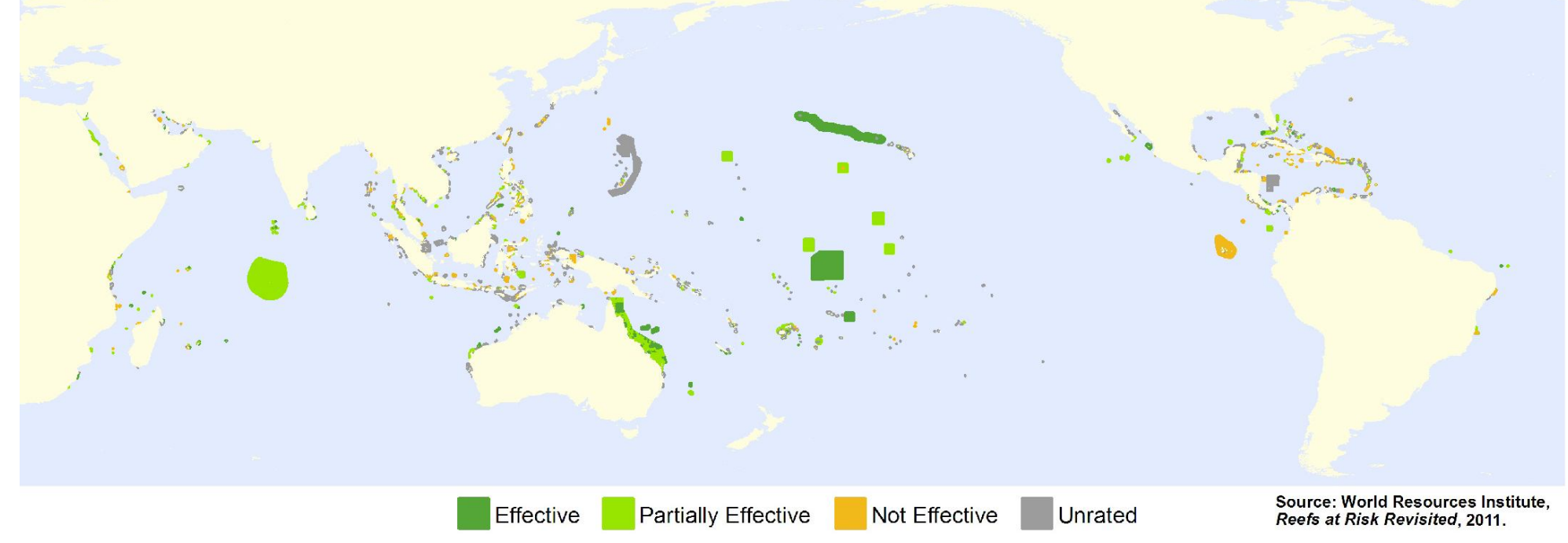

Figure 1.3. Map of Marine Protected Areas in coral reef regions classified according to management effectiveness rating. (Burke et al. 2011). 
Chapter 2. Global comparison of biological outcomes across coral reef fishery management strategies: a meta-analysis

\section{Abstract}

Social-ecological interactions occurring on coral reefs must be carefully governed to maintain reef resilience to disturbance and sustain the human-reef system. Studies have evaluated the effectiveness of some coral reef fishery management strategies, yet we still know little about the success of various strategies across the globe. I conducted a meta-analysis examining the effect of various management strategies on biological indicators of coral reef health. This is the first meta-analysis to compare the effects of management technique (no-take areas versus partial protection), and management arrangements (involving varying groups of actors) on reef health indicators. Analyses reveal that no-take and gear restriction areas are both reasonable management strategies for coral reef fisheries. These two techniques performed similarly in improving coral cover and richness and fish abundance and richness, but no-take areas outperformed gear restriction areas in enhancement of fish biomass. Among management arrangements, community-based management outperformed comanagement and state management in enhancement of fish biomass within no-take areas, yet more diversity of cases is needed to validate findings. This study corroborates previous findings that resilience is essential to maintaining reef health and provide evidence that management has limited effectiveness when reef resilience is lost. Analyses indicate that biological improvement of highly degraded coral reefs may be negligible regardless of management approach, indicating that prioritizing 
minimally degraded reefs may be necessary for effective reef management at a global scale. Further documentation of partial protection strategies and measurement of social outcomes for all types of management would facilitate identification of best management practices for global coral reef fishery management.

\section{Introduction}

Coral reef systems are dynamic and vulnerable social-ecological systems and despite the proliferation of management efforts worldwide, reefs remain vulnerable to human and natural impacts (Burke et al. 2011). A key reason for continuing vulnerability of reefs is a lack of solution-focused research: a database search with keywords "coral reef," "fishing," and "impact" returned over 15 times more studies than the same search with "solution" in the place of "impact" (McClanahan 2011). In addition, within research efforts focusing on management as solutions, no-take areas are studied far more often than any other management strategy, despite the variety of management approaches implemented throughout the world. In a search for studies of coral reef fisheries by management type, no-take area studies were returned three times more than gear restriction studies, over 16 times more than periodic closure studies, and 40 times more than size restriction studies (McClanahan 2011). Research dedicated to study of the many existing management approaches would provide great insight into the solutions that can conserve coral reefs while slso sustaining the social-ecological system.

Current research fails to represent the variety of management approaches in place for coral reefs across the globe. The frequent citation of no-take area research indicates the popularity of this management method as a solution to the decline of coral reef 
systems (McClanahan 2011). No-take areas are widely promoted as an effective means of protecting coral reefs and fish populations and are often considered superior to other methods (e.g., Russ 2002; Lester et al. 2008). While some studies have highlighted the limitations and uncertainties in no-take area performance, they are commonly assumed to be the ideal form of management. Limitations of no-take areas include: reliance upon coercive measures of enforcement and sanctions rather than compliance measures of incentives and self-monitoring; and intensification of existing inequalities in distribution of power and benefits as resource users required to abandon activities in no-take areas are often of lower socio-economic status than those who enforce the rules and those who are allowed to continue non-extractive activities (Christie 2004). Uncertainties in no-take area performance include: the size needed for a no-take area to sustain or enhance surrounding fisheries and movement of fish at all life stages across no-take area boundaries (Sale et al. 2005). Fishers are often wary of and may resist implementation of no-take areas, especially when proposed by the government or perceived as benefitting the government, the tourism industry, or other stakeholder groups unduly more than fishers (McClanahan et al. 2005; McClanahan et al. 2012). Many other management forms exist that are more acceptable to fishers and merit investigation as possible solutions to maintain coral reef systems.

Of the studies that examine management approaches to conserving coral reefs, some have examined the ability of management efforts to improve (or maintain) coral cover (Selig and Bruno 2010) and fish richness, size, density, and biomass (Halpern et al. 2003; Lester et al. 2009) through global meta-analyses, but studies rarely differentiate 
effects by management characteristics. One study that did compare biological outcomes by management type compared adjacent no-take areas and partially protected areas in 11 countries and found some differences, particularly fish density, between management types (Lester et al. 2008). Cinner et al. (2012) found differences in fish biomass between no-take areas and co-managed areas from four countries. These findings do not sufficiently represent the numerous and diverse management efforts across the globe. Here I present a larger scale study accounting for both management techniques (regulations used for management) and management arrangements (the actor groups involved in management) to provide deeper insight into the effectiveness of existing management of coral reef systems around the world.

Study of coral reef management cases from around the world also may provide insight into the resilience and recovery potential of coral reefs. Coral reef resilience can be described as a reef's ability to recover from disturbance and resist phase shifts (Nystrom et al. 2000). Long-term human disturbance has been observed to reduce resilience of coral reefs and lead to shifts from coral-dominated reefs to barren or algaldominated reefs (Hughes et al. 2000; Williams and Polunin 2001; Gardner et al. 2003). While management is often implemented with the expected outcomes of coral reef recovery, or maintenance at the very least, the capacity for management to facilitate coral reef maintenance and recovery is likely to vary throughout the world due to possible confounding factors such as non-managed disturbances, history of disturbance, differing physical conditions such as connectivity, nutrient and light availability, and temperatures. Research is increasingly addressing the role of various actor groups involved in 
management and most recently community-based and a diversity of co-management actors (see Chapter 5) have been promoted for inclusion in resource management, particularly in small-scale fisheries (Berkes et al. 2001; Gutierrez et al. 2011), yet we lack sufficient assessments to determine how community-based and co-management arrangements compare to state and private management arrangements. Research efforts have targeted coral reefs throughout the world, although not equally (Fisher et al. 2011), and regional differences in coral reef health and management have not been thoroughly assessed. This study will examine regional differences and provide prioritized regional targets for coral reef management.

This study employs a meta-analysis approach to compare the status of coral reefs under differing management techniques and arrangements. The goals of this study are to evaluate recovery of coral reef health across management schemes employing a variety of techniques and arrangements, to determine whether less-advocated approaches to management can be as effective as well-advocated approaches, to provide more insight into the management attributes that most contribute to improving (or maintaining) reef health, and to identify whether certain regions should be prioritized for global coral reef management efforts. I hypothesize that partial protection management techniques (such as gear restrictions) can result in improvement of biological indicators of reef health, and that the improvement would be similar to findings from studies of no-take areas. I also hypothesize that there is similar performance among management arrangements. This is the first study to evaluate case studies from around the world, comparing management techniques and actor groups. The findings of this study will facilitate development of a 
suite of best practices for coral reef management to maintain or improve coral reef health. Methods

Meta-analysis is a method of quantitative synthesis of research findings to test a particular hypothesis. It is a means of replication of real-world events that are often difficult to replicate within a single study. Effect sizes from studies are used to calculate an overall effect size and then tested to determine whether the overall effect size is greater than would be expected by chance (Rosenberg et al. 2000). The purpose of this meta-analysis is to compile existing data from coral reef management cases from around the world that comprise a body of evidence of reef health responses to management. Through meta-analysis, findings from cases around the world can be standardized and compared across a variety of management techniques and arrangements.

In January 2013 I conducted a systematic search of published studies and nonpeer reviewed technical reports in Web of Knowledge using the search term "coral" with several management terms (Table 2.1), returning 2043 studies (including duplicate results). I read the title and abstract of returned studies and selected 387 as initial candidate studies for meta-analysis that indicated study of management on tropical coral reefs with measurement of at least one outcome of interest (coral cover, coral richness, fish abundance, biomass, or richness, or catch per unit effort). Additional candidate studies were identified from cited literature in initial candidate studies. Of the candidate studies, 71 studies reported control and treatment data on at least one of the outcome variables of interest (coral cover and richness, fish abundance, biomass, and richness, and catch per unit effort - CPUE), reported the management technique utilized, and indicated 
management compliance. These studies were included in the meta-analysis. While social variables such as livelihood and food security were an initial target for meta-analysis, measurement or even qualitative evaluation of these variables in the searched literature was very rare and insufficient for analysis. CPUE has been used as a proxy for food security by Mascia et al. (2010) and will be discussed as such here.

For each management case, I collected information on: management type, actors involved in management, location and size of managed area, and time since implementation. Some studies reported more than one management case and some cases were reported on in more than one study, so the number of studies and number of management cases do not match (71 studies and 114 cases of management were included in the meta-analysis). Based on the management regulations and actors reported in the studies, the meta-analysis compared no-take areas, gear restrictions (including additional protection measures in some cases, such as catch limits), and periodic harvests for regulations. For actor groups, the meta-analysis compared community-based management, co-management, state management, and private management.

I recorded quantitative data for control and treatment measurements of the target outcomes along with sample size, error estimates, and p-values. I contacted authors to request outcome data that were not reported. I also checked the www.mpaglobal.org database, the official website for each managed area, and contacted authors to obtain management attributes (e.g., size, date of implementation) not reported in the study. Controls consisted of areas with unregulated fishing and could include: management area prior to (or within 1 year of) implementation; an area outside of the managed area but 
within the same country; or a previously managed area that was no longer managed. Treatments consisted of a managed area with specified regulations. For each outcome recorded I calculated a response ratio of treatment/control. The response ratio provides a measure of the difference between control vs. treatment conditions and has the benefit of standardizing the various measurement types used for an outcome into a unitless ratio (Hedges et al. 1999; Rosenberg et al. 2000). Error estimate and sample size for each treatment and control measurement were used as indicators of study quality and studies were weighted using the inverse of variance to account for variation in study quality (see formula below). I used one response ratio per management case for meta-analysis (with variance estimate) or an overall response analysis (without variance, for outcomes that did not have enough cases with reported error estimates for a meta-analysis) of each outcome.

For studies that reported multiple measurements by taxonomic level (for example, a study reporting biomass by species for several fish species), or by other factors (such as by season or depth), these measurements were pooled into overall control and treatment values to obtain an average response ratio by management case (per Halpern 2003 and Lester et al. 2009). For studies that reported measurements over multiple time periods, the time period that represented the longest duration of management was used as the treatment measurement. Response ratios from multiple studies for a single management case were averaged into a single response ratio as in Lester et al. (2009). Where target fish measurements were reported, these values were recorded to allow for a comparison of target fish outcomes with overall fish outcomes, but are not reported here due to the 
similarity of results with overall fish outcomes. Where Before-After-Control-Impact (BACI) data were provided, control and treatment measurements were recorded both before and after treatment, but only the treatment-before and treatment-after data were used in meta-analysis to allow for inclusion of accompanying variance measures. For analyses using only response ratios without variance, BACI outcomes were included using a ratio of change within the managed area controlling for temporal changes outside the managed area ([After-Inside/Before-Inside]/[After-Outside/Before-Outside]).

I used the natural $\log$ of the response ratio $(\ln R)$ for analyses as it is preferred for its statistical properties (Rosenberg et al. 2000). It was calculated from the treatment and control data using the formula:

$$
\ln \mathrm{R}=\ln \left(\overline{\mathrm{X}}^{\mathrm{T}} / \overline{\mathrm{X}}^{\mathrm{C}}\right)
$$

Where $\overline{\mathrm{X}}^{\mathrm{T}}$ is the mean for the treatment group and $\overline{\mathrm{X}}^{\mathrm{C}}$ is the mean for the control group. For the meta-analyses, variance of each response ratio was calculated as:

$$
\mathrm{v}_{\operatorname{lnR}}=\frac{\left(\mathrm{S}^{\mathrm{T}}\right)^{2}}{\mathrm{~N}^{\mathrm{T}}\left(\overline{\mathrm{X}}^{\mathrm{T}}\right)^{2}}+\frac{\left(\mathrm{S}^{\mathrm{C}}\right)^{2}}{\mathrm{~N}^{\mathrm{C}}\left(\overline{\mathrm{X}}^{\mathrm{C}}\right)^{2}}
$$

where $\mathrm{N}^{\mathrm{T}}$ and $\mathrm{N}^{\mathrm{C}}$ respectively represent treatment and control group sample sizes and $\mathrm{S}^{\mathrm{T}}$ and $\mathrm{S}^{\mathrm{C}}$ respectively represent treatment and control group standard deviations.

For the meta-analysis, I used a mixed effects model in MetaWin (version 2.1) to include random variation among studies within management techniques and arrangements and fixed differences between management techniques and arrangements (Rosenberg et al. 2000; Borenstein et al. 2009). A fixed effects model assumes that one true effect size should be shared by all studies, so that any variance in effect size across 
studies is purely due to sampling error and studies are weighted by the inverse of their variance (Rosenberg et al. 2000). A random effects model assumes that variance in effect size across studies can be due to both sampling error and true random variation, such as variation that may occur due to a variable unaccounted for in the study, and within- and between-study variance are used in weighting studies (Rosenberg et al. 2000). Cumulative effect size is calculated as:

$$
\overline{\bar{E}}=\frac{\sum_{i=1}^{n} w_{i} E_{i}}{\sum_{i=1}^{n} w_{i}}
$$

where $n$ is the number of management cases, $w_{i}$ is the weight for the $i^{\text {th }}$ case, and $E_{i}$ is the effect size for the $\mathrm{i}^{\text {th }}$ case (Rosenberg et al. 2000). The equation for cumulative effect size is applicable for both overall effect sizes and subgroup (management techniques and arrangements) effect sizes that were calculated in this study. For the overall effect, all cases are included in the calculation, and for each subgroup effect, only the respective subgroup cases are included in the calculation. In a mixed effects model, weight is calculated as:

$$
\mathrm{w}_{\mathrm{i}}=\frac{1}{\mathrm{~V}_{\mathrm{i}(\mathrm{lnR})}+\sigma^{2}}
$$

where $\mathrm{v}_{\mathrm{i}(\mathrm{lnR})}$ is variance for the $\mathrm{i}^{\text {th }}$ case from above and $\sigma^{2}$ is the between-study variance (Rosenberg et al. 2000).

Variance for the cumulative effect size in a mixed-effects model is calculated as: 


$$
s_{\frac{2}{E}}=\frac{1}{\sum_{i=1}^{n} w_{i}}
$$

with a confidence interval around the cumulative effect size calculated as:

$$
C I=\overline{\bar{E}} \pm t_{\alpha / 2[n-1]} *_{s_{\bar{E}}}
$$

with Student's $t$-distribution used to find the two-tailed critical value $t$ at the critical level $\alpha$ (Rosenberg et al. 2000). Differences between subgroup results were also tested for significance using a $\chi^{2}$ distribution (Rosenberg et al. 2000).

While some studies (e.g., Cote et al. 2001; Cote et al. 2005) used area sampled as a more "biologically meaningful" (Cote et al. 2001) weight for the response ratios rather than the variance, I adhered to more traditional meta-analysis methods that utilize variance as a weight to account for differing sampling effort among studies (Rosenberg et al. 2000; Mengersen et al. 2013).

The number of management cases for coral cover and fish abundance, biomass, and richness allowed for meta-analysis of these outcomes. Coral richness and CPUE were evaluated by comparing response ratios without variance estimates due to fewer cases reporting these outcomes. When sample size allowed, I calculated effect sizes for each management arrangement as subgroups within each management technique. I also investigated the influence of study type (spatial comparison - comparing a managed area to controls outside the managed area, or temporal comparison - comparing a managed area to controls prior to management implementation, or comparing a managed area to controls after breakdown of management in a few cases), number of species 
studied, region (Indo Pacific and Southeast Asia, Caribbean and Atlantic, or Western Indian Ocean and Middle East), size of management area $\left(\ln \left(\mathrm{m}^{2}\right)\right)$, and duration of management (years) on the biological outcomes by management technique. There is often concern in meta-analysis of publication bias, in which published studies are often only the studies with significant findings while evidence of non-significant results remains unpublished, causing a predominance of positive results (Rosenberg et al. 2000). To test for publication bias, I compared effect sizes from published and non-published cases. Results

The majority of management cases found in the literature were no-take areas $(n=82)$, followed by gear restriction areas $(n=27)$, and a few periodic harvest areas $(n=5)$. Both gear restriction areas and no-take areas were mostly managed by the state $(\mathrm{n}=18$ for gear restriction areas and $n=27$ for no-take areas), followed by community-based management ( $\mathrm{n}=6$ for gear restriction areas and $\mathrm{n}=20$ for no-take areas) and comanagement ( $\mathrm{n}=3$ for gear restriction areas and $\mathrm{n}=20$ for no-take areas). No-take areas also had four cases with private management and 11 cases for which the management actor group was not identified. A total of 63 cases reported coral cover, 24 reported coral richness, 50 reported fish abundance, 60 reported fish biomass, 51 reported fish richness, and 9 reported CPUE (see Table 2.2 for numbers of cases in meta-analyses by biological outcome, management technique, and management arrangement).

Comparing outcomes by management technique, no-take areas and gear restriction areas performed similarly in enhancement of coral cover $(\ln R=0.41$ for gear restriction areas, $\ln R=0.18$ for no-take areas, $p=0.33$, fig. $2.1 \mathrm{a})$ and richness $(\ln \mathrm{R}=0.05$ for 
gear restriction areas, $\ln R=0.08$ for no-take areas, t-test, $\mathrm{p}=0.35$, fig.2.2) as well as fish abundance $(\ln R=0.41$ for gear restriction areas, $\ln R=0.42$ for no-take areas, $p=0.7$, fig. $2.1 \mathrm{~b}$ ) and richness ( $\ln \mathrm{R}=0.18$ for gear restriction areas, $\ln \mathrm{R}=0.16$ for no-take areas, $\mathrm{p}=0.41$, fig.2.1d), while no-take areas outperformed gear restriction areas in enhancement of fish biomass $(\ln R=0.46, n=19$, for gear restriction areas; $\ln R=1.13, n=41$, for no-take areas; $\mathrm{p}=0.00013$; fig. $2.1 \mathrm{c} ; \mathrm{n}=27$ for no-take areas with Stockwell et al. 2009 cases removed, $\mathrm{p}=0.044$ for between-group differences). Periodic harvest areas tended to perform more poorly than the other management techniques but were represented by only a few cases $(\mathrm{n}<5)$ for each biological outcome (no periodic harvest cases reported CPUE). No-take areas outperformed gear restriction areas in enhancement of CPUE but these results were confounded by study type, with all no-take areas evaluated temporally and all gear restriction areas evaluated spatially $(\ln R=0.10$ for gear restriction areas, $\ln R=0.78$ for no-take areas; fig. 2.3). Some management cases reporting CPUE outcomes utilized a combination of gear restriction with an adjacent no-take area and the mean response ratio in these cases fell between the response ratios of gear restriction and notake only management areas $(\operatorname{lnR}=0.51$, fig.2.3). No-take and gear restriction area results were not influenced by number of species studied or size of managed area. Study type affected only CPUE results, as discussed above.

Region had an effect on enhancement of fish abundance in gear restriction areas, with the Indo Pacific and Southeast Asia region significantly outperforming the Caribbean and Atlantic region $(\mathrm{p}<0.0001, \mathrm{n}=3$ for Caribbean and Atlantic region, $\mathrm{n}=9$ for Indo-Pacific region; fig.2.4a). Duration of management had a significant positive trend 
$(\mathrm{p}=0.00018, \mathrm{n}=14)$ for coral cover in gear restriction areas, but was largely influenced by two sites with $>30$ years of management while all other cases had 2-20 years of management.

When comparing outcomes by management actor groups, community-based management outperformed state management in enhancement of fish biomass for no-take areas $(\mathrm{p}=0.0032, \mathrm{n}=14$ for community-based management cases, $\mathrm{n}=8$ for state management cases, fig. 2.5f), but community-based management consisted of management cases from a single study (Stockwell et al. 2009) and country (Philippines). Co-management $(\mathrm{n}=2)$ and community-based management $(\mathrm{n}=3)$ outperformed state management in enhancement of fish abundance for gear restriction areas. Where private management was studied (within no-take areas for fish richness and fish abundance), it tended to perform better than any other management actors ( $\mathrm{p}<0.0001$ for fish richness; fig $2.5 \mathrm{~h}$; but not significantly better for fish abundance), but also had a small sample size ( $\mathrm{n}=3$ for fish richness and $\mathrm{n}=2$ for fish abundance).

Unpublished case studies included technical reports $(\mathrm{n}=8$ reporting a total of 33 management cases), conference proceedings ( $\mathrm{n}=2$ reporting a total of 2 cases), and dissertations ( $\mathrm{n}=2$ reporting a total of 2 cases). Cumulative effect sizes of published and unpublished cases were not significantly different for any biological outcome ( $p>0.1$ for all outcomes; fig. 2.6).

\section{Discussion}

No-take areas outperform gear restriction areas (fig.2.1c) in enhancement of fish biomass, but the two management techniques produce similar positive outcomes in fish 
abundance, fish richness, and coral cover. Among the no-take areas, enhancement of fish biomass in community-managed areas was significantly greater than in state managed areas (fig.2.5f), but because the community-managed cases were from a single study and country, a more diverse group of cases is necessary to confirm the findings of this analysis. However, no-take area enhancement of fish biomass remained significantly greater than gear restriction areas when the Stockwell et al. (2009) cases were excluded from analysis. The greater improvement of CPUE in unmanaged areas adjacent to notake areas than within gear restriction areas (fig.2.3) was confounded by study type yet supports the findings of fish spillover from no-take areas reported in other studies (e.g., Halpern et al. 2010; Russ et al. 2011).

An important finding was the capacity for recovery of biological outcomes across cases, which can differ even across cases in which the same management technique is applied. Results indicated that the effectiveness of management in enhancing fish abundance and biomass varied by geographic region. Management areas in the Caribbean and Atlantic region greatly underperformed managed areas under the same techniques in other regions (fig2.4a-d). Caribbean coral reefs have lost $80-90 \%$ of coral cover since the 1970s and 1980s (Gardner et al. 2003) and are currently considered the most extensively degraded reefs in the world (Hughes et al. 2010). The findings of this study, that management efforts fail to improve fish abundance and biomass in the Caribbean and Atlantic region, support the reports of loss of resilience in the region (discussed in Mumby et al. 2007; Hughes et al. 2010, among others). This underscores the importance of proactive management focused on maintenance of healthy reefs where possible, rather 
than reactive management efforts attempting to restore reefs that may be too degraded to benefit from management efforts.

Our results differ from findings in the Lester et al. (2008) study comparing adjacent no-take and partially protected areas. While Lester et al. (2008) found greater benefits from no-take areas, particularly for fish density, our results show benefits of notake areas in enhancement of fish biomass, but no significant differences between no-take areas and partially protected (gear restriction) areas for other outcomes (fish abundance and richness and coral cover and richness). This is likely to be due to the more comprehensive data set utilized in this study and could also be due to a selection bias in the studies in Lester et al. (2008) for exemplary no-take areas. This study found improvement of fish biomass in co-managed areas as did the Cinner et al. (2012) study, but improvement was significant only for no-take areas and was not significantly different than the improvements of community-based management and state management in no-take areas (fig.2.5f).

While biological findings of our study are encouraging, there is a severe lack of information on social outcomes in the literature, most likely due to a lack of research on social outcomes, prohibiting analysis of these outcomes. CPUE, as a proxy for food security, was reported in nine cases and the only social outcome for which I was able to make qualitative comparisons by management technique. The small sample size not only precluded statistical analysis, but also meant that the outcome was easily confounded, highlighting the need for more samples to validate our findings. A study by Mascia et al. (2010) evaluating social outcomes across tropical and non-tropical MPAs also found 
insufficient data for statistical analysis. More studies need to consider social outcomes of livelihood, food security, resource rights and social equity, in addition to catch rates and income (Mascia et al. 2010). If study of social outcomes can provide evidence of positive effects of management similar to those found for biological outcomes, these findings could encourage stakeholders to maintain current management efforts and may inspire management efforts in unmanaged areas. There is also a need for greater study of partial protection management efforts, especially periodically harvested areas, catch limits, and other alternatives to no-take areas that are severely underrepresented in the available literature, as observed in this study and by McClanahan (2011). Additional case studies of various management techniques and arrangements will increase the ability of metaanalysis methods to further identify differences in outcomes and delve into the effects of factors such as management duration, actors involved in management, and size of managed area on management outcomes. Such analyses could identify best management practices for application in current and future management efforts.

Given the variety of socio-ecological contexts for coral reefs around the world, a suite of best management practices suited to differing socioeconomic settings are required for maintenance or enhancement of coral reef health. This study takes primary steps towards developing a suite of best management practices, with evidence that notake areas provide optimal enhancement of fish biomass and that gear restriction areas perform similarly to no-take areas in enhancement of fish abundance and richness and coral cover and richness. To further develop a suite of best management practices for coral reefs, research is need to address the following data gaps: biological outcomes of 
partial protection management techniques including periodic harvests and catch limits; additional cases reporting biological outcomes for co-management, community-based management, and private management; and missing from the literature, reporting of social outcomes across all types of management techniques and arrangements. 
Table 2.1. Search terms used in Web Of Knowledge

\begin{tabular}{|l|l|}
\hline Search & $\begin{array}{l}\text { Number } \\
\text { of } \\
\text { results }\end{array}$ \\
\hline coral AND "community based management" & 38 \\
\hline coral AND "community management" & 6 \\
\hline coral AND "community based" & 106 \\
\hline coral AND "co-management" & 32 \\
\hline coral AND "comanagement" & 31 \\
\hline coral AND "custom*” & 89 \\
\hline coral AND "tradition*” & 548 \\
\hline coral AND ("marine protected area" OR "protected area" OR MPA) & 609 \\
\hline coral AND "marine reserve" & 395 \\
\hline coral AND ("collaborat*” OR "private") & 189 \\
\hline
\end{tabular}


Table 2.2. Number of cases in meta-analyses of biological outcomes by management techniques and arrangements.

\begin{tabular}{|c|c|c|c|c|c|c|c|c|c|c|c|c|c|c|c|c|c|}
\hline & \multicolumn{8}{|l|}{ G } & \multicolumn{8}{|l|}{ NTA } & \multirow{2}{*}{$\begin{array}{l}\text { PH } \\
\text { Total }\end{array}$} \\
\hline & Total & $\mathrm{C}$ & $\mathrm{CO}$ & $\mathrm{P}$ & $\mathrm{S}$ & $\mathrm{CA}$ & IP & WIO & Total & $\mathrm{C}$ & $\mathrm{CO}$ & $\mathrm{P}$ & $\mathrm{S}$ & $\mathrm{CA}$ & IP & WIO & \\
\hline Coral cover & 14 & 5 & 3 & - & 6 & 1 & 8 & 5 & $49 *$ & 16 & 13 & - & 11 & 3 & 42 & 4 & 2 \\
\hline Fish abundance & 13 & 3 & 2 & - & 8 & 3 & 9 & 1 & $37 *$ & 5 & 14 & 2 & 15 & 7 & 28 & 2 & 3 \\
\hline Fish biomass & 19 & 6 & 3 & - & 10 & 2 & 13 & 4 & $41^{*}$ & 14 & 6 & 1 & 18 & 8 & 31 & 2 & 4 \\
\hline Fish richness & 16 & 4 & 1 & - & 11 & 2 & 11 & 3 & $35^{*}$ & 3 & 10 & 3 & 10 & 3 & 31 & 1 & 3 \\
\hline
\end{tabular}

*: totals that are greater than the sum of management arrangement categories because management arrangements were not specified for all cases. G:Gear restriction area; NTA: No-take area; PH: Periodic harvest area; C: Community-based management; CO: Co-management; P: Private management; S: State management; CA: Caribbean and Atlantic region; IP: Indo-Pacific and Southeast Asia region; WIO: Western Indian Ocean and Middle East region. 

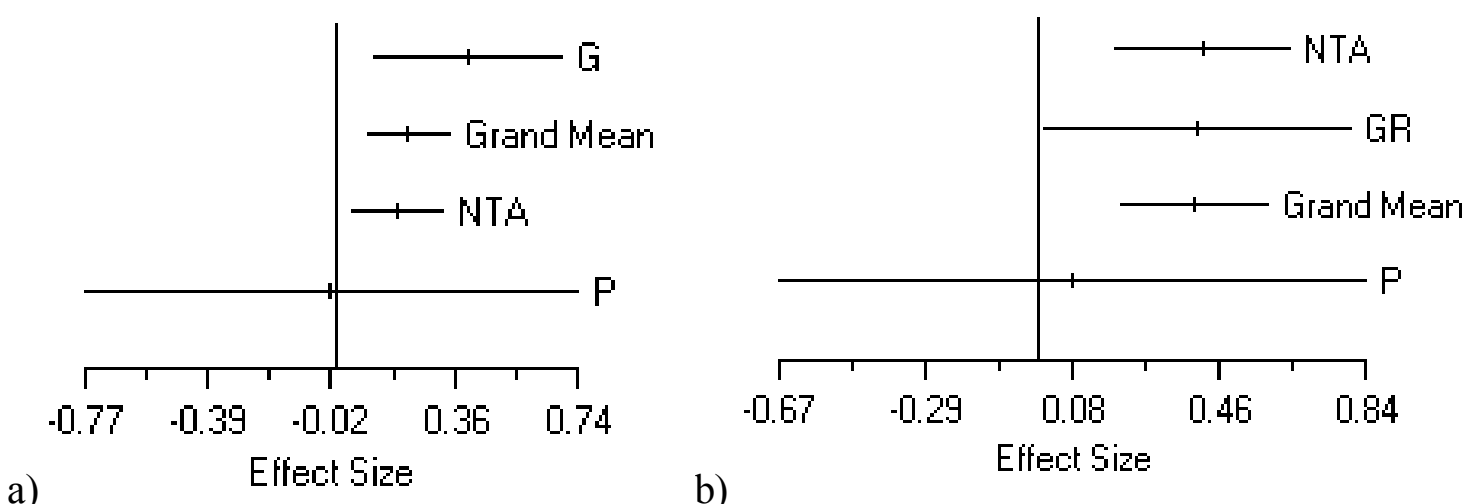

b)

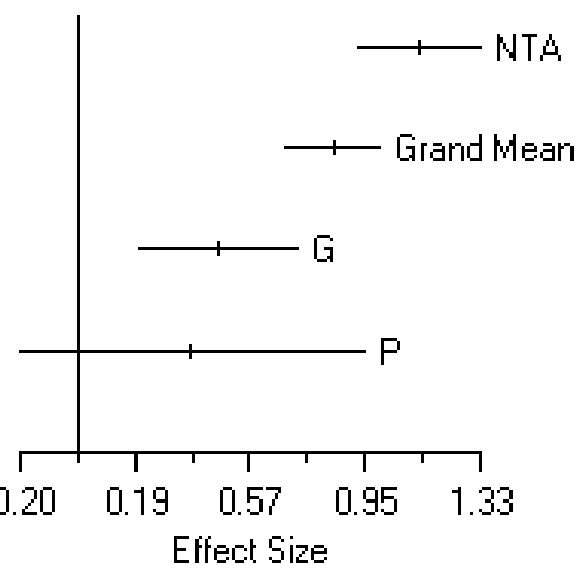

c)

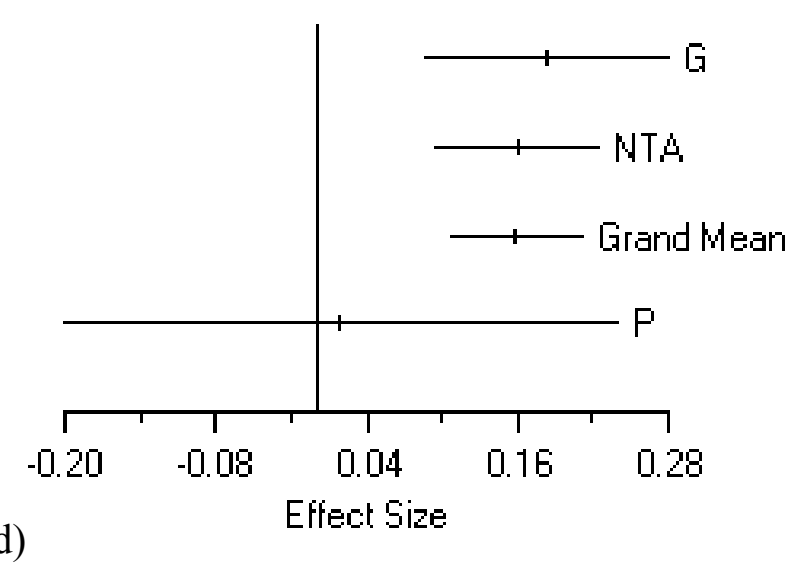

Figure 2.1 Meta-analysis results by management technique. Results for a) coral cover, b) fish abundance, c) fish biomass, d) fish richness. Cumulative effect sizes reported as the natural $\log$ response ratio $(\operatorname{lnR})$ with 95\% confidence intervals. Positive effect sizes represent improvements with management, negative effect sizes represent declines with management, and zero (signified by the vertical axis) represents no change with management. Improvements and declines were significant where confidence interval does not include zero (vertical line). G: gear restriction area; NTA: no-take area; P: periodic harvest area. 


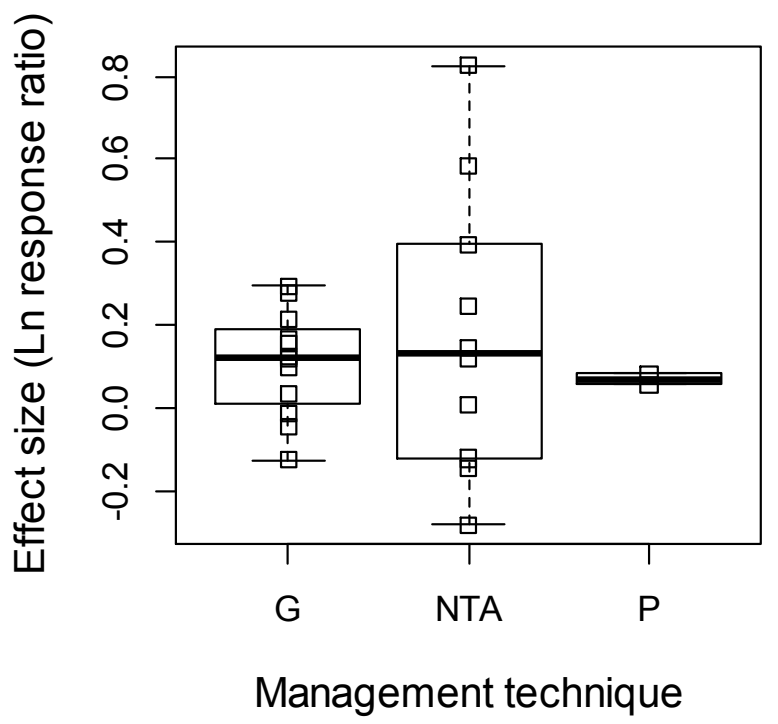

Figure 2.2. Response ratios of coral richness by management technique. Box plot of natural log response ratios for each case by management technique. Positive effect sizes represent improvements with management, negative effect sizes represent declines with management, and zero represents no change with management. G: gear restriction area $(\mathrm{n}=12)$; NTA: no-take area $(\mathrm{n}=10) ;$ P: periodic harvest area $(\mathrm{n}=2)$. 


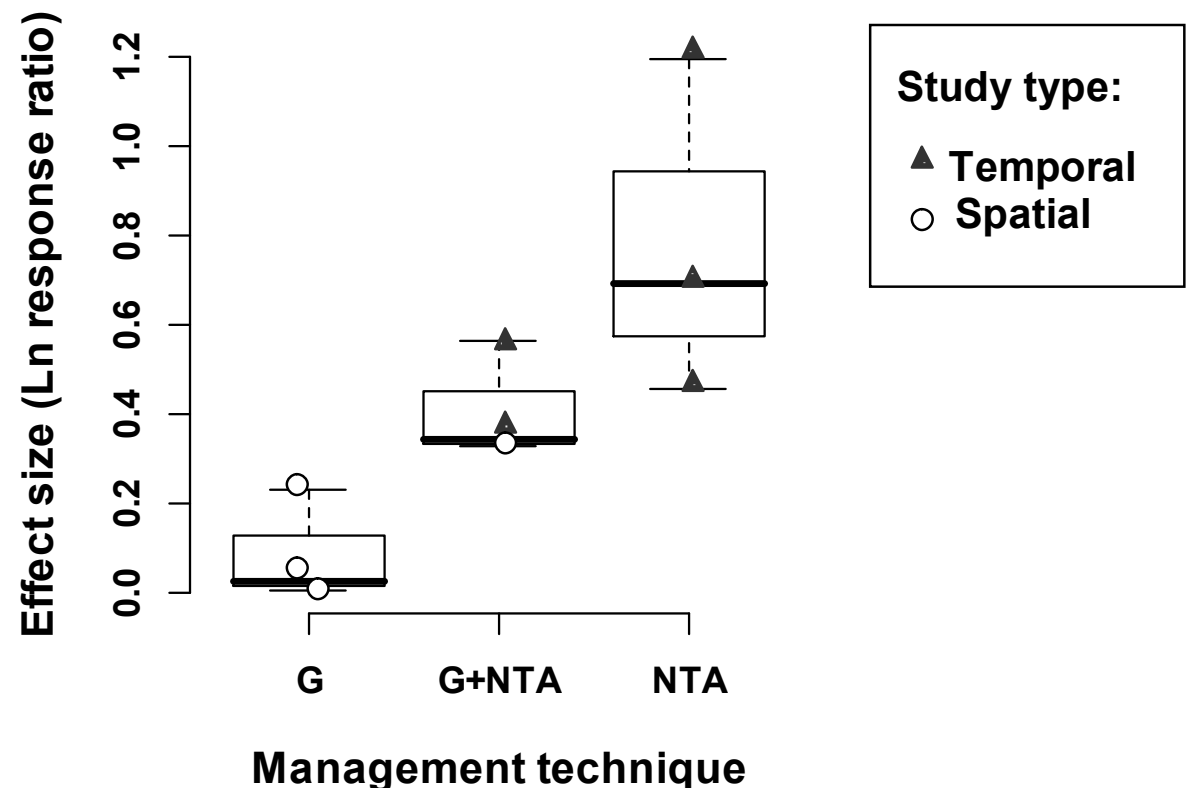

Figure 2.3 Mean response ratios of catch per unit effort (CPUE) by management technique. Box plot of natural log response ratios for each case by management technique. Positive effect sizes represent improvements with management, negative effect sizes represent declines with management, and zero represents no change with management. G: gear restriction area $(n=3)$; $\mathrm{G}+\mathrm{NTA}$ : gear restriction area $\&$ adjacent notake area $(n=3)$; NTA: no-take area $(n=3)$. Temporal represents cases with temporal comparison of control and treatment measurements. Spatial represents cases with a spatial comparison of measurements. 


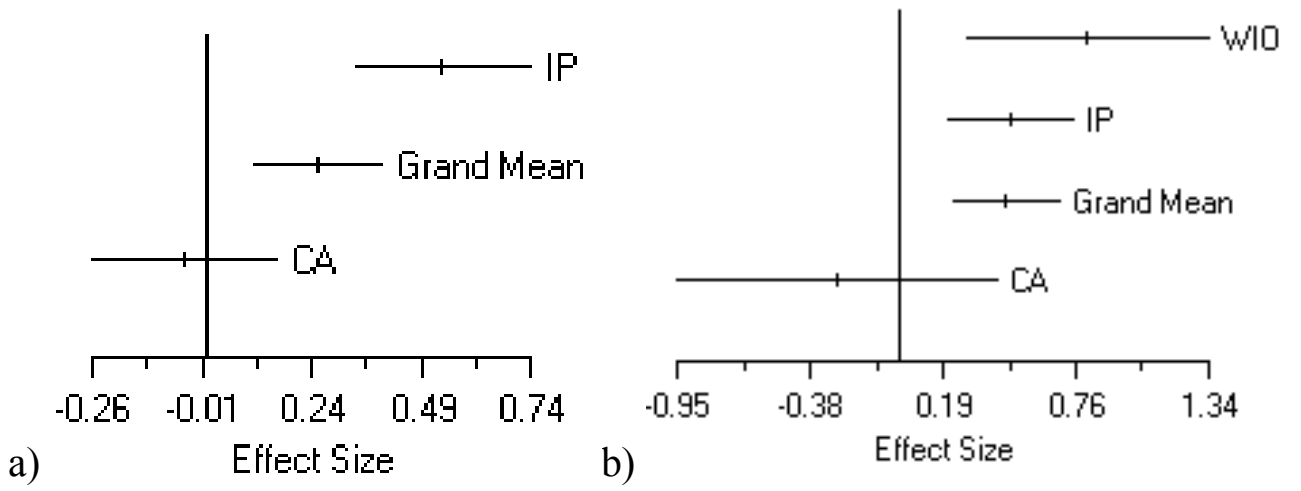

a)

Effect Size b)

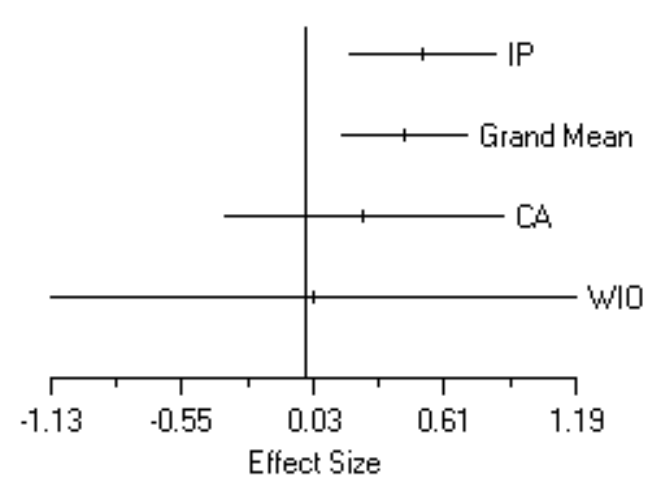

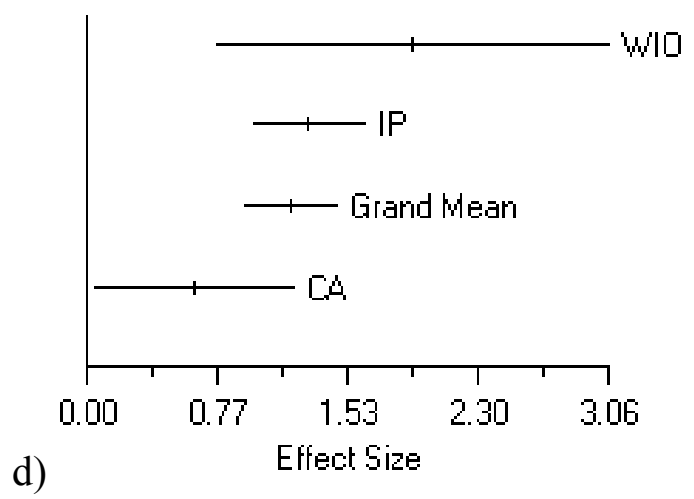

Figure 2.4. Meta-analysis results for management techniques by region. Results for a) gear restriction area fish abundance, b) gear restriction area fish biomass, c) no-take area fish abundance, d) no-take area fish biomass. Cumulative effect sizes reported as the natural $\log$ response ratio $(\operatorname{lnR})$ with $95 \%$ confidence intervals. Positive effect sizes represent improvements with management, negative effect sizes represent declines with management, and zero (signified by the vertical axis) represents no change with management. Improvements and declines were significant where confidence interval does not include zero (vertical line). CA: Caribbean and Atlantic region; IP: Indo Pacific and Southeast Asia region; WIO: Western Indian Ocean and Middle East region. 
a)
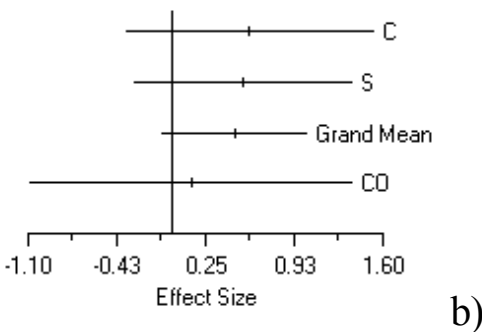

b)

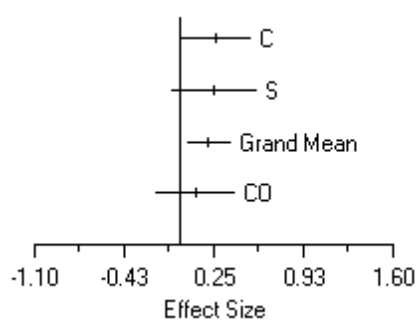

Effect Size

c)
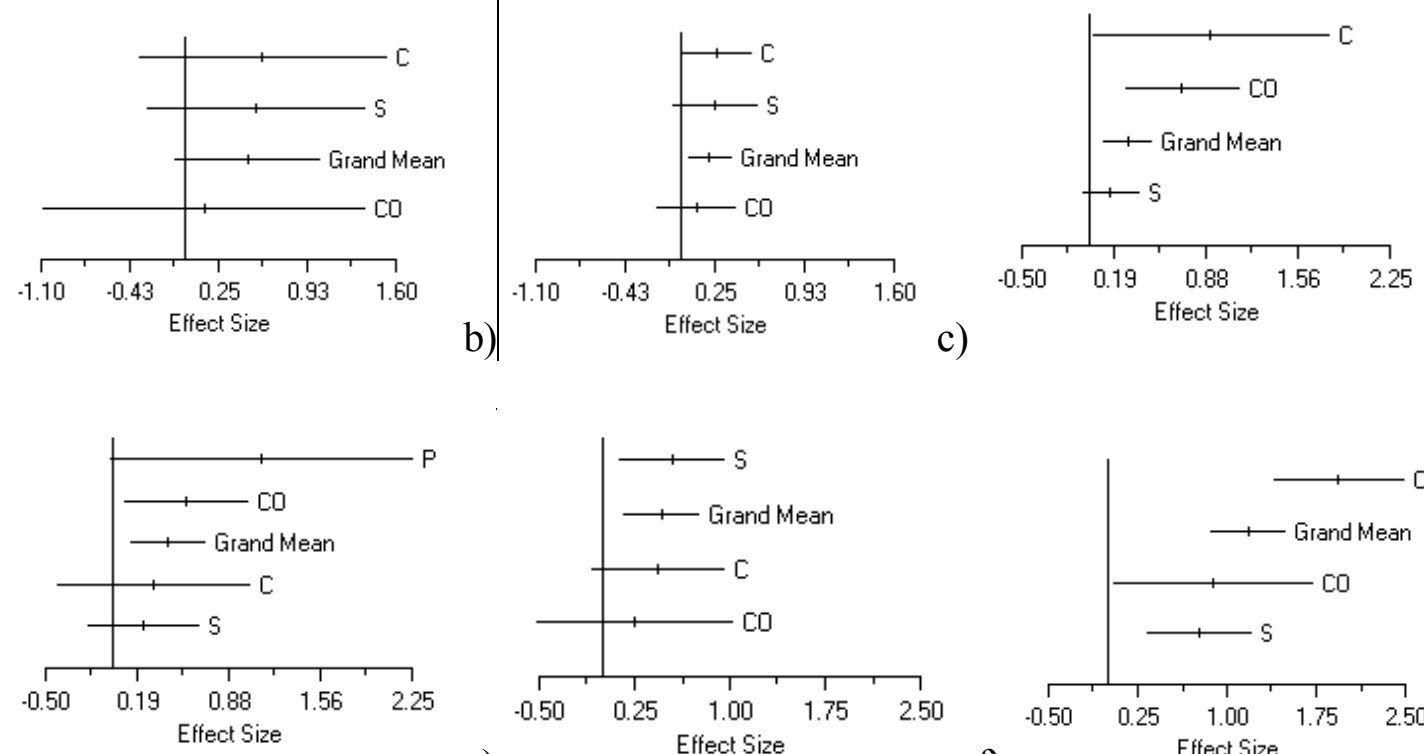

d)

e)

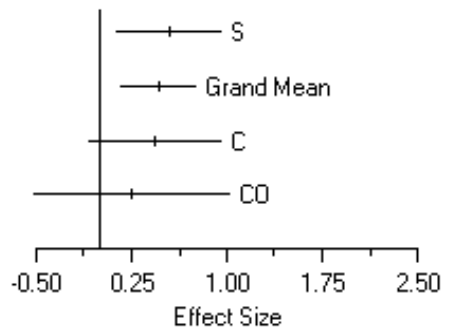

f)

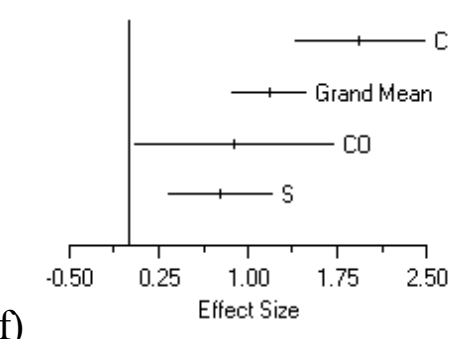

g)

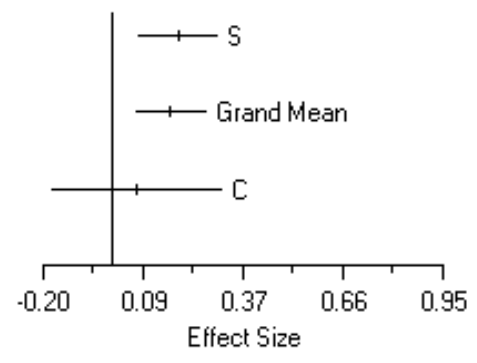

h),

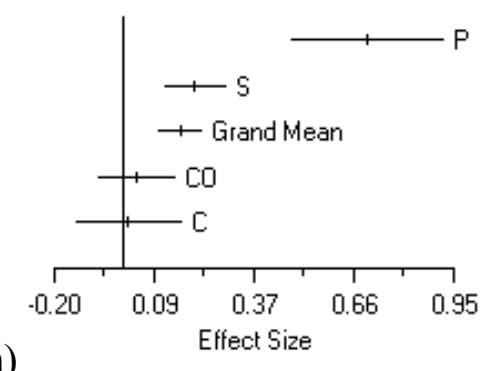

Figure 2.5. Meta-analysis results for management actor groups. Results for a) gear restriction area coral cover, b) no-take area coral cover, c) gear restriction area fish abundance, d) no-take area fish abundance, e) gear restriction area fish biomass, f) notake area fish biomass, g) gear restriction area fish richness, h) no-take area fish richness. Cumulative effect sizes reported as the natural log response ratio (lnR) with $95 \%$ confidence intervals. Positive effect sizes represent improvements with management, negative effect sizes represent declines with management, and zero (signified by the vertical axis) represents no change with management. Improvements and declines were significant where confidence interval does not include zero (vertical line). C: communitybased management; $\mathrm{CO}$ : co-management; P: private management; S: state management. 


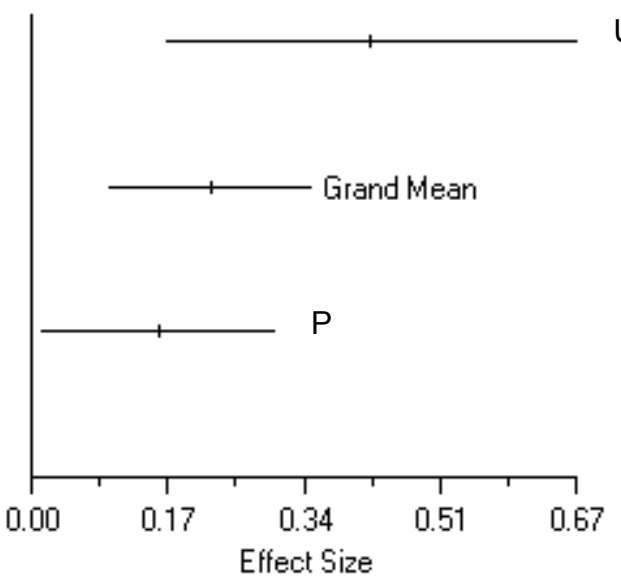

a)

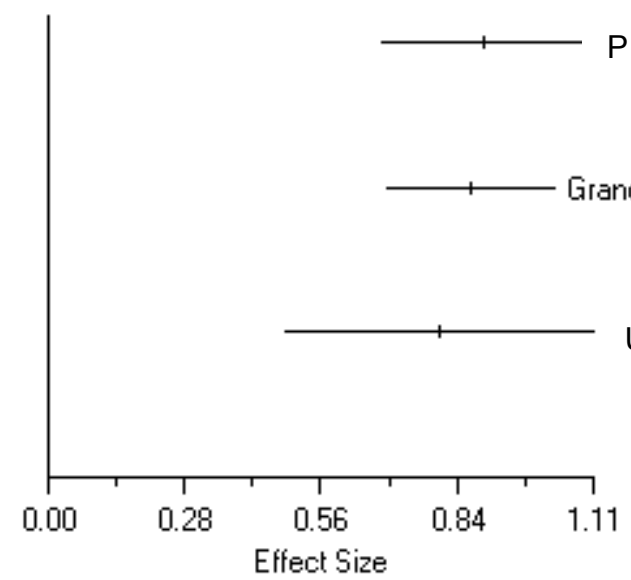

c)

Figure 2.6. Detection of publication bias in meta-analysis. Results for a) coral cover, b) fish abundance, c) fish biomass, d), fish richness. Cumulative effect sizes reported as the natural $\log$ response ratio $(\operatorname{lnR})$ with 95\% confidence intervals. Positive effect sizes represent improvements with management, negative effect sizes represent declines with management, and zero (signified by the vertical axis) represents no change with management. Improvements and declines were significant where confidence interval does not include zero (vertical line). P: published cases; U: unpublished cases. 


\section{Literature Cited}

Berkes, F., R. Mahon, P. McConney, R. Pollnac, R. Pomeroy. 2001. Managing SmallScale Fisheries Alternative Directions and Methods. Ottawa: International Development Research Centre, 309pp.

Borenstein, M., L.V. Hedges, J.P.T. Higgins, H.R. Rothstein. 2009. Introduction to MetaAnalysis. West Sussex, UK: Wiley.

Burke, L., K. Reytar, M. Spalding, and A. Perry. 2011. Reefs at Risk Revisited. World Resources Institute, Washington, DC. 111p.

Christie, P. 2004. Marine Protected Areas as biological successes and social failures in Southeast Asia. American Fisheries Society Symposium 42:155-164.

Cinner, J.E., T.R. McClanahan, M.A. MacNeil, N.A.J. Graham, T.M. Daw, A. Mukminin, D.A. Feary, A.L. Rabearisoa, A. Wamukota, N. Jiddawi, S.J. Campbell, A.H. Baird, F.A. Januchowski-Hartley, S. Hamed, R. Lahari, T. Morove, J. Kuange. 2012. Comanagement of coral reef social-ecological systems. Proceedings of the National Academy of Sciences 109:5219-5222.

Cote, I.M., I. Mosquiera, J.D. Reynolds. 2001. Effects of marine reserve characteristics on the protection of fish populations: a meta-analysis. Journal of Fish Biology 59:178-189.

Cote, I.M., J.A. Gill, T.A. Gardner, A.R. Watkinson. 2005. Measuring coral reef decline through meta-analyses. Philosophical Transactions of the Royal Society $B$ $360: 385-305$ 
Fisher, R., B.T. Radford, N. Knowlton, R.E. Brainard, F.B. Michaelis, M.J. Caley 2011. Global mismatch between research effort and conservation needs of tropical coral reefs. Conservation Letters 4:64-72.

Gardner, T.A. et al. 2003. Long-term region-wide declines in Caribbean corals. Science $301,958-960$

Gutierrez, N.L., R. Hilborn, O. Defeo. 2011. Leadership, social capital and incentives promote successful fisheries. Nature 470:386-389.

Halpern, B.S. 2003. The Impact of Marine Reserves: Do Reserves Work and Does Reserve Size Matter? Ecological Applications 13:S117-S137.

Halpern, B.S., S.E. Lester, J.B. Kellner. 2010. Spillover from marine reserves and the replenishment of fished stocks. Environmental Conservation 36: 268-276.

Hedges, L.V., J. Gurevitch, P.S. Curtis. 1999. The meta-analysis of response ratios in experimental ecology. Ecology 80:1150-1156.

Hughes, T.P. and Tanner, J.E. 2000. Recruitment failure, life histories, and long-term decline of Caribbean corals. Ecology 81: 2250-2263.

Hughes, T.P., N.A.J. Graham, J.B.C. Jackson, P.J. Mumby, R.S. Steneck. 2010. Rising to the challenge of sustaining coral reef resilience. Trends in Ecology and Evolution 25:633-642.

Lester, S.E., and B.S. Halpern. 2008. Biological responses in marine no-take reserves versus partially protected areas. Marine Ecology Progress Series 367:49-56.

Lester, S.E., B.S. Halpern, K. Grorud-Colvert, J. Lubchenco, B.I. Ruttenberg, S.D. Gaines, S.Airame, and R.R. Warner. 2009. Biological effects within no-take marine reserves: a global synthesis. Marine Ecology Progress Series 384:33-46.

Mascia, M.B., C.A. Claus, R. Naidoo. 2010. Impacts of Marine Protected Areas on fishing communities. Conservation Biology 24:1424-1429. 
McClanahan, T.R. 2011. Human and coral reef use interactions: from impacts to solutions? Journal of Experimental Marine Biology and Ecology 408:3-10.

McClanahan, T.R., J. Maina, J. Davies. 2005. Perceptions of resource users and managers towards fisheries management options in Kenyan coral reefs. Fisheries Management and Ecology 12:105-112.

McClanahan, T.R., C.A. Abunge, J.E. Cinner. 2012. Heterogeneity in fishers' and managers' preferences towards management restrictions and benefits in Kenya. Environmental Conservation 39:357-369.

Mengersen, K., C.H. Schmid, M.D. Jennions, J. Gurevitch. 2013. Statistical models and approaches to inference. In Handbook of Meta-analysis in Ecology and Evolution, J. Koricheva, J. Gurevitch, and K. Mengersen, eds. Princeton, NJ: Princeton University Press; pp 89-107.

Mumby, P.J., A. Hastings, H.J. Edwards. 2007. Thresholds and the resilience of Caribbean coral reefs. Nature 450:98-101.

Nystrom, M., C. Folke, and F. Moberg 2000. Coral reef disturbance and resilience in a human-dominated environment. Trends in Ecology \& Evolution 15:413-417.

Rosenberg, M.S., D.C. Adams, J. Gurevitch. 2000. METAWIN Version 2: Statistical Software for Meta-Analysis. Boston, MA: Sinauer Associates.

Russ, G.R. 2002. Yet another reiew of marine reserves as reef fisheries management tools. In Coral Reef Fishes Dynamics and Diversity in a Complex Ecosystem, P.F. Sale, ed. Academic Press pp. 421-443.

Russ,G.R. and A.C. Alcala. 2011. Enhanced biodiversity beyond marine reserve boundaries: The cup spillith over. Ecological Applications 21:241-250. 
Sale, P.F., R.K. Cowen, B.S. Danilowicz, G.P. Jones, J.P. Kritzer, K.C. Lindeman, S. Planes, N.V.C. Polunin, G.R. Russ, Y.J. Sadovy, R.S. Steneck. 2005. Critical science gaps impede use of no-take fishery reserves. Trends in Ecology \& Evolution 20:74-80.

Selig, E.R. and J.F. Bruno. 2010. A global analysis of the effectiveness of marine protected areas in preventing coral loss. PLoS ONE 5:e9278.

Stockwell, B., C.R.L. Jadloc, R.A. Abesamis, A.C. Alcala, G.R. Russ. 2009. Trophic and benthic responses to no-take marine reserve protection in the Philippines. Marine Ecology Progress Series 389:1-15.

Williams, I.D. and Polunin, N.V.C. 2001. Large-scale associations between macroalgal cover and grazer biomass on mid-depth reefs in the Caribbean. Coral Reefs 19: $358-366$. 


\section{Literature in Meta-Analysis}

Abesamis, R.A. and G.R. Russ. 2005. Density-dependent spillover from a marine reserve: Long-term evidence. Ecological applications 15:1798-1812.

Alcala, A.C., G.R. Russ, A.P. Maypa, H.P. Calumpong. 2005. A long-term, spatially replicated experimental test of the effect of marine reserves on local fish yields. Canadian journal of fisheries and aquatic sciences 62:98.

Alcala, A.C. and G.R. Russ. 1990. A direct test of the effects of protective management on abundance and yield of tropical marine resources. Journal du Conseil 46:4047.

Amargós, F.P. 2010. An experiment of fish spillover from a marine reserve in Cuba. Environmental biology of fishes 87:363.

Ardiwijaya, R.L., T. Kartawijaya, Y. Herdiana, F. Setiawan. 2007. Technical report - the coral reefs of northern Sumatra: an ecological survey of Weh and Aceh Islands, April 2006. Bogor, Indonesia: WCS Marine Program Indonesia 24pp.

Aswani, S., S. Albert, A. Sabetian, T. Furusawa. 2007. Customary management as precautionary and adaptive principles for protecting coral reefs in Oceania. Coral Reefs 26:1009-1021.

Aswani, S. and A. Sabetian. 2010. Implications of urbanization for artisanal parrotfish fisheries in the Western Solomon Islands. Conservation biology 24:520-530.

Bartlett, C.Y. 2009. Comparison of outcomes of permanently closed and periodically harvested coral reef reserves. Conservation biology 23:1475.

Bohnsack, J. A. 1981. Effects of piscivorous predator removal on coral reef fish community structure. Gutshop '81: fish food habits studies. G. M. Cailliet and C. 
A. Simenstad, eds. Washington Sea Grant Publication, Seattle, Washington, USA p.258-267.

Brown-Saracino, J. 2007. Spatial variation in sea urchins, fish predators, and bioerosion rates on coral reefs of Belize. Coral reefs 26:71.

Campbell, S.J., M.S. Pratchett, A.W. Anggoro, R.L. Ardiwijaya, N. Fadli, Y. Herdiana, T. Kartawijaya, D. Mahyddin, A. Mukminin, S.T. Pardede, E. Rudi, A.M. Siregar, A.H. Baird. 2007. Disturbance to coral reefs in Aceh, Northern Sumatra: Impacts of the Sumatra-Andaman tsunami and pre-tsunami degradation. Tsunamis and Coral Reefs 544:55-78.

Campbell, S.J., J.E. Cinner, R.L. Ardiwijaya, S.T. Pardede, T. Kartawijaya, A. Mukminin, Y. Herdiana, , A.S. Hoey, M.S. Pratchett, and A.H. Baird. 2012. Avoiding conflicts and protecting coral reefs: Customary management benefits marine habitats and fish biomass. Oryx 46:486-494.

Chapman, M.R. 1999. Gradients in coral reef fish density and size across the Barbados Marine Reserve boundary: effects of reserve protection and habitat characteristics. Marine ecology. Progress series 181: 81.

Chateau, O. and L. Wantiez. 2005. Comparison of coral reef fish communities between two fished and one protected reefs in New Caledonia South Lagoon Marine Park. Cybium 29:159-174

Christie, P., D. Buhat, L.R. Garces, A.T. White. 2003. The challenges and rewards of community-based coastal resources management : San Salvador Island, Philippines. In Contested Nature-Promoting International Biodiversity Conservation with Social Justice in the Twenty-first Century. Brechin, S.R., P.R., 
Wilshusen, C.L. Fortwangler, P.C. West, eds. Albany, NY:SUNY Press pp.231249.

Cinner JE; Marnane MJ; McClanahan TR. 2005. Conservation and community benefits from traditional coral reef management at Ahus Island, Papua New Guinea. Conservation Biology 6:1714-1723.

Cinner, J., M. J. Marnane, T. R. McClanahan, and G. R. Almany 2005. Periodic closures as adaptive coral reef management in the Indo-Pacific. Ecology and Society 11: 31. [online] URL: http://www.ecologyandsociety.org/vol11/iss1/art31/

Coles, S.L. 2008. Assessment of species composition, diversity and biomass in marine habitats and subhabitats around offshore islets in the main Hawaiian Islands. Final report prepared for the Hawai'i coral reef initiative and the National Fish and Wildlife Foundation. Bishop Museum Technical Report.

Cros, A. and T.R. McClanahan. 2003. Coral transplant damage under various management conditions in the Mombasa Marine National Park, Kenya. Western Indian Ocean Journal of Marine Science 2:127-136.

Dumas P.; Jimenez H.; Leopold M. 2010. Effectiveness of village-based marine reserves on reef invertebrates in Emau, Vanuatu Environmental Conservation 37:364-372

Dung, L.D. 2009. Nha Trang Bay marine protected area, Vietnam: Initial trends in coral structure and some preliminary linkages between these trends and human activities (2002-2005). Aquatic ecosystem health \& management 12:249.

Epstein, N. 2005. Alleviating impacts of anthropogenic activities by traditional conservation measures: can a small reef reserve be sustainedly managed? Biological conservation $121: 243$. 
Evans R.D. and G.R. Russ. 2004. Larger biomass of targeted reef fish in no-take marine reserves on the Great Barrier Reef, Australia. Aquatic Conservation 14:505-519.

Fonseca, M.S. 2006. Ongoing monitoring of Tortugas ecological reserve: assessing the consequences of reserve designation. NOAA Technical Memorandum.

Friedlander, A.M., Brown, E., Monaco, M.E., and Clark, A. 2006. Fish Habitat Utilization Patterns and Evaluation of the Efficacy of Marine Protected Areas in Hawaii: Integration of NOAA Digital Benthic Habitats Mapping and Coral Reef Ecological Studies. Silver Spring, MD. NOAA Technical Memorandum NOS NCCOS 23. 213 pp.

Friedlander, A.M., L.M. Wedding, E. Brown, M.E. Monaco. 2010. Monitoring Hawaii's Marine Protected Areas: Examining spatial and temporal trends using a seascape approach. NOAA Technical Memorandum NOS NCCOS 117. Silver Spring, MD:NCCOS center for Coastal Monitoring and Assessment Biogeography 130pp.

Galal N; Ormond RFG; Hassan O. 2002. Effect of a network of no-take reserves in increasing catch per unit effort and stocks of exploited reef fish at Nabq, South Sinai, Egypt. Marine and Freshwater Research 53: 199-205.

Goetze, J. S. 2011. Evidence of artisanal fishing impacts and depth refuge in assemblages of Fijian reef fish. Coral reefs 30:507.

Grigg, R. W. 1994. Effects of sewage discharge, fishing pressure and habitat complexity on coral ecosystems and reef fishes in Hawaii. Marine Ecology-Progress Series $103: 25-34$. 
Hamilton R. J.; Potuku T.; Montambault J. R.2011. Community-based conservation results in the recovery of reef fish spawning aggregations in the Coral Triangle. Biological Conservation 144:1850-1858.

Harborne, A. R. 2009. Reduced density of the herbivorous urchin Diadema antillarum inside a Caribbean marine reserve linked to increased predation pressure by fishes. Coral reefs 28:783.

Hawkins, J.P. 2006. Effects of habitat characteristics and sedimentation on performance of marine reserves in St. Lucia. Biological conservation 127:487.

Hernandez Delgado, E.A., B.J. Rosado, A.M. Sabat. 2006. Management failures and coral decline threatens fish functional groups recovery patterns in the Luis Pena Channel No-take Natural Reserve, Culebra Island, Puerto Rico. Proceedings of the 57th Gulf and Caribbean Fisheries Institute pp577-605.

Hoffman, T.C. 2002. The reimplementation of the Ra'ui: coral reef management in Rarotonga, Cook Islands. Coastal Management 30:401-418.

Jennings, S., E.M. Grandcourt, N.V.C. Polunin. 1995. The effects of fishing on the diversity, biomass, and trophic structure of Seychelles' reef fish communities. Coral Reefs 14:225-235.

Kamukuru, A. 2004. Evaluating a marine protected area in a developing country: Mafia Island Marine Park, Tanzania. Ocean \& coastal management 47:321.

Karnauskas, M. 2011. Pre-existing spatial patterns in fish abundances influence speciesspecific responses in a Caribbean marine reserve. Marine ecology. Progress series $432: 235$. 
Kellner, J.B. 2010. Disentangling trophic interactions inside a Caribbean marine reserve. Ecological Applications $20: 1979$.

Kramer, K.L. 2007. Top-down trophic shifts in Florida Keys patch reef marine protected areas. Marine ecology. Progress series 349:111.

Kuo, C.Y., Y.S. Yuen, P.J. Meng, P.H. Ho, J.T. Wang, P.J. Liu, Y.C. Chang, C.F. Dai, T.Y. Fan, H.J. Lin, A.H. Baird, C.A. Chen. 2012. Recurrent disturbances and the degradation of hard coral communities in Taiwan. PLoS ONE 7(8):e44364. doi:10.1371/journal.pone.0044364.

Letourneur, Y. 1996. Reponses des peuplements et populations de poissons aux reserves marines: le cas de l'ile de Mayotte, Ocean Indien occidental. Ecoscience 3:442450.

Mangi, S. and T.R. McClanahan. 2003. The effect of a marine protected area and the exclusion of beach seines on coral reef fisheries. In Recent advances in coastal ecology. Studies from Kenya. p171.

McClanahan, T.R. 1997. The effects of traditional fisheries management on fisheries yields and the coral-reef ecosystems of southern Kenya. Environmental conservation 24:105-120.

McClanahan, T. R. and S. Mangi. 2000. Spillover of exploitable fishes from a marine park and its effect on the adjacent fishery. Ecological applications 10:1792-1805. McClanahan, T.R. and B. Kaunda-Arara. 1996. Fishery Recovery in a Coral-reef Marine Park and Its Effect on the Adjacent Fishery. Conservation biology 10:1187-1199. 
McClanahan, TR; Verheij, E; Maina, J. 2006. Comparing the management effectiveness of a marine park and a multiple-use collaborative fisheries management area in East Africa. Aquatic Conservation 16:47-165.

McCook, L. J. 2010. Marine Reserves Special Feature: From the Cover: Adaptive management of the Great Barrier Reef: A globally significant demonstration of the benefits of networks of marine reserves. Proceedings of the National Academy of Sciences 107:18278.

Miller, J., E. Muller, C. Rogers, R. Waara, A. Atkinson, K.R.T. Whelan, M. Patterson, B. Witcher. Coral disease following massive bleaching in 2005 causes $60 \%$ decline in coral cover on reefs in the US Virgin Islands. Coral Reefs 28:925-937.

Monaco, M.E. 2009. Long-term monitoring of habitats and reef fish found inside and outside the US Virgin Islands Coral Reef National Monument: A comparative assessment. Caribbean Journal of Science 45:338.

Nardi, K., G.P. Jones, M.J. Moran, Y.W. Cheng. 2004. Contrasting effects of marine protected areas on the abundance of two exploited reef fishes at the sub-tropical Houtman Abrolhos Islands, Western Australia. Environmental conservation 31 : $160-168$.

Newman MJH, Paredes GA, Sala E, Jackson J. 2006. Structure of Caribbean coral reef communities across a large gradient of fish biomass. Ecology Letters 9:12161227

Page, C.A. 2009. Influence of marine reserves on coral disease prevalence. Diseases of Aquatic Organisms 87:135. 
Pittman, S.J. 2008. Fish assemblages and benthic habitats of Buck Island Reef National Monument (St. Croix, U.S. Virgin Islands) and the surrounding seascape: a characterization of spatial and temporal patterns. NOAA Technical Memorandum NOS NCCOS 71.

Poonian, C. N. S. 2008. The influence of protected area management on the status of coral reefs at Misali Island, Tanzania following the 1998 bleaching event in the western Indian Ocean. African journal of ecology 46: 471.

Preuss, B. 2009. Considering multiple-species attributes to understand better the effects of successive changes in protection status on a coral reef fish assemblage. ICES journal of marine science 66: 170.

Raymundo, L.J. 2008. Marine protected area surveys of the central Visayas, Philippines 2007. University of Guam Marine Laboratory Technical Report.

Roberts, C. M., and N. V. C. Polunin. 1993. Marine reserves:simple solutions to managing complex fisheries? Ambio 22:363-368.

Roberts CM, Bohnsack JA, Gell F, Hawkins JP, Goodridge R. 2001. Effects of marine reserves on adjacent fisheries. Science 294:1920-1923

Russ, G.R. 2008. Rapid increase in fish numbers follows creation of world's largest marine reserve network. Current biology 18:R514.

Russ, G.R. and A.C. Alcala. 2003. Marine reserves: rates and patterns of recovery and decline of predatory fish, 1983-2000. Ecological Applications 13:1553-1565.

Russ, G.R. and A.C. Alcala. 1989. Effects of intense fishing pressure on an assemblage of coral reef fishes. Marine Ecology Progress Series 56:13-27. 
Stockwell, B., C.R.L. Jadloc, R.A. Abesamis, A.C. Alcala, G.R. Russ. 2009. Trophic and benthic responses to no-take marine reserve protection in the Philippines. Marine Ecology Progress Series 389:1-15.

Svensson, P. 2009. Privately Managed Marine Reserves as a Mechanism for the Conservation of Coral Reef Ecosystems: A Case Study from Vietnam. Ambio $38: 72$.

Tkachenko, K.S. 2010. Protection of Habitat Types: A Case Study of the Effectiveness of a Small Marine Reserve and Impacts of Different Habitats on the Diversity and Abundance of Coral Reef Fishes. Zoological studies 49:195.

Tyler, E.H.M., M. Andrea, J. Narriman. 2011. A role for partially protected areas on coral reefs: maintaining fish diversity? Aquatic Conservation 21:231-238.

Walmsley SF; White AT. 2003. Influence of social, management and enforcement factors on the long-term ecological effects of marine sanctuaries. Environmental Conservation 30: 388-407

Wantiez, L., P. Thollot, and M. Kulbicki. 1997. Effects of marine reserves on coral reef fish communities from five islands in New Caledonia. Coral Reefs 16:215-224.

Watson, D.L. 2007. Protection from fishing alters the species composition of fish assemblages in a temperate-tropical transition zone. Marine biology 152: 1197.

White, A.T. 1985. Marine parks and reserves: Management for Philippine, Indonesian and Malaysian coastal reef environments. Univesity of Hawaii 298pp.

White, A.T. 1991. Philippine-Tubbataha reef National Marine Park status, management issues, and proposed plan. Environmental conservation $18: 148$. 
White, A.T., D. Apistar, S. Tesch, R. Martinez and E. White. 2010. Summary field report: Coral reef monitoring expedition to Southern Cebu, Philippines March 22-29 2010. Cebu City:The Coastal Conservation and Education Foundation, Inc. $76 \mathrm{pp}$.

Williams, I.D. 2009. Impacts of a Hawaiian marine protected area network on the abundance and fishery sustainability of the yellow tang, Zebrasoma flavescens. Biological conservation $142: 1066$.

Zvuloni, A. 2010. Diversity Partitioning of Stony Corals Across Multiple Spatial Scales Around Zanzibar Island, Tanzania. PloS one 5: e994 
Chapter 3. Impacts of local anthropogenic activities on the world's most vulnerable reefs: A case study of the Comoros

\section{Abstract}

Localized anthropogenic activities can greatly threaten coral reef health, yet activities other than fishing are rarely studied and tend to be studied individually, without consideration of additional impacts thus limiting the potential for effective management. Identification of the suite of activities driving declines on a particular coral reef would allow more targeted and most likely more effective management. The island nation of the Comoros is a model setting to study activity impacts on coral reefs. The islands of the Comoros harbor reefs with abundant and diverse marine life, yet local dependence upon reef resources and a variety of anthropogenic pressures on reefs render the Comoros critically vulnerable to the effects of coral reef degradation. I evaluated the relative influence of natural and anthropogenic variables on benthic cover and fish richness, abundance, and biomass at 21 sites throughout the Comoros with the goal of providing prioritized management targets. Human activities including fishing, sand extraction, and beachfront housing and development had the strongest relationship with reef health but with some seasonal fluctuation, while geographic patterns most consistently predicted reef health. Comparing analyses conducted with and without the suite of activities, the inclusion of activities greatly improved explanatory power. Baseline data on reef health and localized anthropogenic impacts, monitoring over time, and controlled experiments can facilitate an adaptive management approach for protecting fragile reef ecosystems in the Comoros and elsewhere. 


\section{Introduction}

Coral reefs provide valuable ecosystem functions and services that are compromised by increasing anthropogenic pressures (Moberg and Folke 1999). Local pressures currently threaten over $60 \%$ of the world's coral reefs (Burke et al. 2011). A report outlining threats to coral reefs placed over-fishing and destructive fishing practices, various forms of pollution, and coastal development among the 'top ten' threats to coral reefs (Wilkinson 2004). Human disturbances, such as increased sedimentation and nutrients from coastal development, changes in land cover, and resultant terrestrial runoff, reduced fish abundance and/or diversity from overfishing, and chemical and petroleum pollution from boating, often persist over time, unlike natural disturbances that tend to be brief or episodic (Nystrom et al. 2000). The weakening effect of human disturbances on reef resilience makes recovery from natural disturbances more difficult (Nystrom et al. 2000). Regarding climate change impacts, studies suggest that reducing local threats to a coral reef can enhance its resilience and is a strategy for mitigating detrimental effects of climate change while global greenhouse gas emissions remain high (Hoegh-Guldberg et al. 2007; Hughes et al. 2007; but see also Graham et al. 2008; McClanahan 2008). While there is growing awareness of anthropogenic effects on coral reefs and the need to reduce these effects as human populations continue to grow along global coastlines, current knowledge lacks the precision and predictive power necessary to prevent regime shifts and conserve coral reefs in many locales (Bellwood et al. 2004).

Few reef-impacting activities have been studied in depth and detailed information on activities and their effects on reef resilience is not available for the vast majority of 
coral reefs (Bellwood et al. 2004; Burke et al. 2011). Recent studies investigating human impacts on coasts (e.g. Halpern et al. 2008; Halpern et al. 2009; Klein et al. 2010) focus on a large regional scale rather than providing detailed information at the smaller scale at which most management regimes operate. The information provided by these studies is difficult to translate to management action due to scale mismatch and lack of relevance for poorly studied reef areas with the highest diversity and the greatest need for effective management (Burke et al. 2011; Fisher et al. 2011). In addition, drivers of declining reef health are context specific and high local and regional variability exists in key drivers of reef threats, current reef health status, and management efforts (Burke et al. 2011). Despite such variability, research effort has not concentrated on coral reefs under heaviest resource use, greatest anthropogenic impacts, and the most at risk for coral reef degradation (Fisher et al. 2011). Instead, research effort is highly clustered, positively related to per capita Gross Domestic Product (GDP), and actually declines in relation to coral diversity (Fisher et al. 2011; but see Dorenbosch et al. 2005; Cinner et al. 2006; Graham et al. 2008 as examples of research in locales with low GDP and high coral diversity). The poor allocation of research effort means that the impacts of many heavily practiced activities on reefs in resource dependent (and low GDP) locales are poorly understood and unlikely to be effectively managed. Local and sub-regional scale research and management is necessary to address the variability in reef threats and reef health status and to avoid the missteps and challenges of transferring findings across regions (Burke et al. 2011; Fisher et al. 2011).

Studies evaluating human impacts at sub-regional scales tend to investigate individual impacts (most often fishing; e.g. Jennings and Polunin 1996; McClanahan et 
al. 2008) or cumulative impacts in which the effects of particular activities are indiscernible (e.g. Sala et al. 2012). Activities (other than fishing) and their effects on coral reefs have been studied in few locales, including boating (Burgin and Hardiman 2011), sand extraction (Huber and Meganck 1990), coastal development (Wolanski et al. 2009), and agriculture (Fabricius and De'ath 2004). These studies of individual activities or cumulative impacts provide little understanding of the effects reefs face under a variety of human activities that occur on many reefs. In short, we know reefs are threatened by human activity, but we know few specifics about the what and where of human impacts on reefs throughout the world, least of all in the areas in most need of this knowledge to maintain local reef health, global biodiversity, and the well-being and livelihoods of the millions who depend on coral reefs.

This lack of knowledge is a considerable impediment to effective management and maintenance of reef health. Although local managers often recognize the presence of various reef-impacting activities, the activities are rarely studied in a way that informs successful management (e.g. Ohman et al 1994; Ahamada et al. 2002; Munday 2004). Even the zoning plan for the Great Barrier Reef Marine Park in Australia, considered one of the most advanced marine management plans in the world, did not initially consider "external" impacts on the ecosystem such as sedimentation and eutrophication from land use and development (Ruckelshaus et al. 2008). Given the financial, personnel, and time constraints of any management operation, management will most effectively conserve the ecosystem when threats are identified and scientifically studied to inform and prioritize management actions (Klein et al. 2010). 
When investigating human activity and management effects on reef health, it is important to account for a variety of potential sources of degradation and natural patterns in ecosystem health (Garcia Charton et al. 2000). Factors such as wave exposure, sedimentation, and recruitment patterns can greatly influence reef community composition (Done 1982). Anthropogenic variables found to affect reef health include population, distance to markets, and socioeconomic development (Cinner and McClanahan 2006; Cinner et al. 2009). This study simultaneously evaluates the influence of suites of human activities and natural factors on reef health, an approach yet to be utilized, but essential to providing management-relevant information. While many studies have evaluated the effects of either natural factors (e.g. McGehee 1994; Olds et al. 2012) or an activity (most often fishing; e.g. Mumby et al. 2006; McClanahan et al. 2008) on reef health, incorporating suites of natural and human impacts into a single study allows us to identify the respective influence of each on reef health and indicate courses of management action to facilitate maintenance or improvement of reef health.

This study evaluates, at a management-relevant scale, the relationship of human activities with reef health in the Comoros islands with the aim of identifying the activities most detrimental to reef health and in most need of management. The Comoros is listed among nine nations most vulnerable to the effects of coral reef degradation due to high reef dependence, highly threatened reefs, and low adaptive capacity (Burke et al. 2011). Like other understudied reefs, the reefs of the Comoros contain high biodiversity and experience high levels of human impact. The 2002 GCRMN World Status of Coral Reefs report for the Comoros listed several activities that contribute to reef degradation, emphasizing the urgent need for management (Ahamada et al. 2002). These activities 
include: men's and women's fishing; coral and sand extraction; beachfront housing and development; tourism; agriculture; and transport in and around reef areas by motorized fiberglass boat. The influence of each of these activities on reef health has been studied individually or cumulatively on other reefs (Table 3.1). Here, I examine the impacts of the suite of activities on 21 reefs in the Comoros. I developed scales indicating the intensity of activity and management for each of the eight activities and identified which activities best predicted benthic cover and fish populations. I also determined the relative impact of activities on coral reef health in comparison to effects of natural and anthropogenic factors. I expected to find a suite of activities (most likely including fishing and sand extraction) would best explain the variation in reef health among the study sites and would enhance explanatory power of analytical models in comparison with the usual suite of natural and anthropogenic factors. This investigation provided clear directives of activities to target in management efforts at the study sites and revealed the influence of activities that are likely to affect coral reefs under heavy resource use in other locales. The study also provides a method of identifying local threats to coral reefs and recommendations of management actions to reduce these threats that can be applied to coral reef management at reef resource dependent sites throughout the world.

Methods

Study site and design - The islands of the Comoros archipelago that make up the Comoros Union include Grande Comore, Anjouan, and Moheli. These volcanic islands were produced from geologic 'hotspot' processes less than 10 million years ago (Emerick and Duncan 1982). The coral reefs that surround the islands are seldom subject to 
catastrophic storms or crown of thorns outbreaks and have proven to be resilient to major coral bleaching events such as the 1998 event (Ahamada et al. 2002). The reefs studied consist mainly of fringing reefs with high hard coral diversity; I identified 23 scleractinian coral genera during the study, most often observing Acropora, Porites, Favites, Echinopora, and Goniastrea. I conducted interviews and ecological surveys at 21 sites throughout the Comoros. Each site consisted of a local community with a population between approximately 250-13,000 inhabitants (unpublished 2003 census data from Comoran government) and an adjacent area of reef frequented by the community along $250 \mathrm{~m}-1000 \mathrm{~m}$ of coastline. Sites were selected to geographically represent the reefs of each island to the extent possible and based on reef access via snorkel (SCUBA is unavailable for most of the sites).

Before-After-Control-Impact (BACI) study designs incorporating spatial and temporal replication provide the strongest evidence for detecting and evaluating both management and disturbance effects in the field (Underwood 1994). Although resources, capacity, the natural field setting, and the unpredictability of events often preclude the implementation of this study design, several alternative approaches can provide reliable results (Michener 1997). "Before" data prior to introduction of activities and their management and true "control" sites with no human impact were not available for this study and I therefore evaluated reef health impacts at several sites representing a gradient of human activity and management efforts. Accounting for other sources of variation in reef health, I assumed that any discernible relationship between activities and reef health would be a conservative estimate of the true effects of activities that could be more precisely quantified were "before" and "control" data available. 
Reef health - Reef health can be measured in many ways. A recent study found total fish biomass, live coral cover, crustose coralline algal cover, and presence of pathogenic bacteria to be effective reef health indicators (Kaufman et al 2011). In this study I evaluated benthic cover including percent cover of hard coral, turf algae, and fish biomass, abundance, and taxonomic richness (a measure of relative rather than absolute richness, as in Garpe et al. 2006) for 13 indicator species from Conand et al. (1998) and 15 additional species (two of which were not included in pre-rainy season surveys), one additional genus, one additional subfamily, and four additional families of local anthropogenic or ecological importance.

Ecological surveys were designed to closely match protocols utilized by Wildlife Conservation Society in Kenya (McClanahan 2008) while maintaining consistency with methods used in the Comoros for GCRMN reports (e.g., Ahamada et al. 2002). I conducted ecological surveys on fringing reef at $<1-6 \mathrm{~m}$ deep at low tide, using line-pointintercept transects (25m in length, 2-3 per site) for benthic cover, identifying benthic cover at $25 \mathrm{~cm}$ intervals along each transect (100 observations per transect). Each benthic cover observation was reported as one of nine categories: live scleractinian coral cover; non-scleractinian coral cover; turf algal cover; macroalgal cover; coralline algal cover; crustose coralline algal cover; dead coral cover; abiotic cover (sand, silt, bare substrate); and other biotic cover (zoanthids and gorgonians). Mean percent cover of each category was determined for each site using the numbers of observations in each category for each transect. I conducted belt transect surveys ( $25 \mathrm{~m}$ in length and $5 \mathrm{~m}$ width, $2-3$ per site) for fish along the benthic cover transects. I recorded counts of each species (or other taxonomic group) and size of individuals in categories of 3 to $10 \mathrm{~cm},>10$ to $30 \mathrm{~cm}$, and 
$>30 \mathrm{~cm}$ to facilitate biomass estimation. Fish abundance was reported for each site as the mean number of fish per transect (number of individuals $125 \mathrm{~m}^{-2}$ ). Fish biomass was calculated using species Length-Weight tables (Froese and Pauly 2012) to determine the average weight of fish in each species and size class. The average weight was then multiplied by the number of fish observed in that species-size class for each transect to determine mean biomass per transect $\left(\mathrm{kg} 125 \mathrm{~m}^{-2}\right)$ for each site. Fish richness was reported as the total number of species and other taxonomic groupings (of 34 possible) observed at each site. I conducted surveys twice at each site to account for seasonal differences, once during the pre-rainy season from September-December 2010 and once during the rainy season from January-March 2011. I did not conduct surveys from AprilAugust due to high winds and wave action and poor visibility during those months. Activities--Due to sparse existing information and the large number of activities to investigate, I gathered data on each activity through interviews with community members knowledgeable of coastal activities at each site. Although I did not have the time or resources to obtain absolute measures of activity intensity, I used information from the interviews in a scaled comparison of relative intensity of activities and management across sites. Interview questions focused on eight potential reef impacting activities: men's fishing-most often conducted offshore in a dugout canoe or motorized boat; women's fishing-most often conducted on foot from the shore or on shallow reef; sand extraction; coral extraction; agriculture, tourism; coastal housing and construction; transport by motorized boat (Ahamada et al. 2002); and on management of three activities involving use of common-pool resources, men's fishing, women's fishing, and sand extraction. The interviews included open-ended questions that allowed us to gather 
qualitative information and structured questions for which responses were scored. Scored responses were combined into a scaled variable of intensity of activity and management for each activity (Table 3.2). I conducted interviews and observations from May through August 2009 with additional interviews and observations from September 2010 through March 2011 to update our findings to coincide with collection of ecological data and to determine whether any changes had occurred since our last interviews. Interview methods are described in detail in Chapter 4.

Other natural and anthropogenic variables - I collected information on environmental, geographic, and anthropogenic variables including: island, latitude, longitude, coastline orientation, wave exposure, reef depth, rugosity, habitat types adjacent to the reef, distance to seagrass habitat, distance to mangrove habitat, visibility, season, population of adjacent human settlement, and distance to major markets (Table 3.2). To measure visibility on the reef, one researcher would remain stationary at the start of the transect while a second assistant would hold a white board about $1 \mathrm{~m}$ below the water surface perpendicular to the bottom and swim away from the first assistant along the transect. The first researcher would signal when he could no longer see the board and the second would record the distance from the transect start point where visibility ceased. Visibility was not measured at all sites in the pre-rainy season as I developed the methodology while sampling was underway. I also included temporal variables of season (pre-rainy or rainy) and the number of days from the first sampling day that a site was surveyed. The number of transects that were repeated in each season at each site was included as I planned to conduct surveys along permanent transect lines in each season, but some of 
the markers were lost between seasons and required us to conduct surveys along new transect lines.

Data analysis - I used Principal Components Analysis (PCA; MASS package in R) of benthic data from all transects to identify and remove outliers (Jolliffe 1986) and logtransformed fish abundance and biomass to meet assumptions of normality. Fish biomass and abundance were analyzed using the summed values for all taxa as a high proportion of zero-values made values for individual taxa and functional groups unsuitable for analysis (Zuur et al. 2007). Analysis was performed on a total of 18 sites each with two samples, one in the pre-rainy season and one in the rainy season $(n=36$ for analysis of combined seasons).

I selected a subset of predictors to include in the analysis due to small sample size as well as multi-colinearity among predictors. Selected predictors had few zeros, few missing data, and high variance without gaps in levels of treatment. Preference was given to predictors with correlation of 0.50 or greater with multiple other predictors. One to three predictors were retained in each category: geographic (2: island and coastline orientation of each site), environmental (3: depth, rugosity, and number of days since first sampling day), anthropogenic (1: population of the adjacent community from 2003 census, log-transformed), and activities (3: men's fishing, sand extraction, and beachfront development). Where data were missing for depth at one site, I used the mean depth of all other sites as a place-holder to retain the site for analysis.

To assess the relationships between reef health variables and activities, population, and geographic and environmental variables, I performed redundancy analysis (RDA) and a permutation test of significance of the model. In RDA, ordination 
axes are constrained to a linear combination of the explanatory variables (Rao 1964;

Legendre and Legendre 1998; Bouchon-Navarro et al. 2005; Zuur et al. 2007). I plotted the RDA results using a distance triplot as a two-dimensional approximation of the correlation between response and predictor variables (Zuur et al. 2007).

To determine the relative effect of activities and other predictor variables on reef health, I partitioned the variance of reef health variables among activity, environmental, geographic, and anthropogenic categories using partial redundancy analysis (partial RDA; vegan package in R). In partial RDA, a matrix of species or other response variables is related to a matrix of environmental or other explanatory variables while removing the effects of another explanatory matrix (Zuur et al. 2007). I also conducted partial RDA analysis on each seasonal data set separately to identify seasonal discrepancies. To identify seasonal differences in individual reef health indicators and in relationships between reef health indicators and various activities, population, environmental, and geographic variables, I plotted seasonal data in scatter plots or bar plots as appropriate.

Results

Of the natural and anthropogenic variables studied, human activities had the strongest relationship with reef health. Men's fishing, women's fishing, and agriculture were the most commonly practiced activities and were present at all sites. Moderate or better management (in which the community respects management; see Table 3.2) took place at 11 sites for men's fishing and 9 sites for women's fishing. Coastal housing was present at 13 sites with continuing development along the beach taking place at five of those sites. Sand extraction was practiced at 13 sites with moderate or better management 
of the activity at two sites. Tourism and transport by motorized boat each took place at 13 sites. While interviewees at several sites stated that coral extraction was a common practice over twenty years ago, it is currently the least commonly practiced activity, being occasionally practiced at two sites. The practice ceased mainly with the import of cement, which replaced the need for lime produced from harvested coral. Current coral collection is infrequent and in very small quantity for use as a decorative makeup. Most interviewees recognized the detrimental effects of coral removal.

Benthic cover and fish richness, abundance, and biomass varied among sites and seasons. Scleractinian coral cover ranged from $1 \%$ to $35 \%$ across sites. Turf algal cover was between $42 \%$ and $83 \%$ across sites. All other benthic cover types made up less than one third of total benthic cover at each site and were not included in further analysis to meet the requirements of few zero-values in the data for redundancy analysis (Zuur et al. 2007). Dead coral and abiotic cover were in low abundance $(<10 \%$ cover) at most sites. Non-scleractinian coral, macrolgae, coralline algae, and other benthic cover including hydroids and zoanthids were present at few sites and in low abundance. Fish taxonomic richness was between 4 and 14 for each site, average fish abundance was between 24 and 99 individuals $125 \mathrm{~m}^{-2}$ for each site, and average fish biomass was between 1.1 and 100.3 $\mathrm{kg} 125 \mathrm{~m}^{-2}$ for each site. Seasonal differences in reef health were observed, with fish abundance, biomass, and richness increasing at many sites during the rainy season (Fig. 3.1). The increases in biomass were strongest at sites with fewest numbers of fishing boats (as a proxy for fishing pressure; Pinca et al. 2012), but this pattern was not as strongly observed for fish abundance and richness. An inverse logarithmic regression best described the relationship between seasonal change in fish biomass and number of fishing 
boats at each site $\left(r^{2}=0.4356\right.$, Fig. $\left.3.1 b\right)$. However, seasonal changes in fish abundance and richness displayed very weak relationships with number of fishing boats at each site $\left(r^{2}=0.0004\right.$, Fig. 3.1a; $r^{2}=0.0411$, Fig. 3.1c; respectively).

Redundancy analysis (RDA) revealed relatively strong relationships among reef health variables and the selected activity, population, geographic and environmental variables (Fig.3.2). RDA results indicated that fish richness and biomass were negatively related to population, unrestricted men's fishing, island, and depth (Fig. 3.2). Fish richness decreased with depth and fish biomass was highest at mid-depths $(>1-2 \mathrm{~m})$. Turf algal cover was positively related to Eastern site orientation (Fig. 3.2). Live hard coral cover and fish abundance were positively related to Western site orientation (Fig. 3.2). Approximately $51 \%$ of the variation in reef health variables was explained by activity, population, geographic, and environmental variables, with the first two axes explaining $29 \%$ (RDA1) and 13\% (RDA2) of variation ( $\mathrm{p} \leq 0.001$ for both axes). RDA1 may represent a gradient of reef disturbance, from reefs with diverse benthic cover and healthy and diverse fish populations to turf algal dominant reefs with low fish abundance, biomass, and diversity. Turf algal cover increased along RDA1 while live hard coral cover, fish richness, abundance, and biomass decreased. This gradient was associated positively with human population and island and negatively with coastline orientation. RDA2 may represent a gradient of robust to poor fish diversity and size as fish richness and biomass increased along RDA2. Turf algal cover was also positively related to RDA2, while live hard coral cover and fish abundance were negatively related to RDA2. Rugosity and sand extraction were strongly positively correlated with RDA2 while 
human population, men's fishing, depth, and island were negatively correlated with RDA2.

Partial RDA revealed that both natural and anthropogenic variables related to reef health. Of the $51 \%$ of variance explained by the geographic, environmental, anthropogenic, and activity variables and their interactions, the largest proportion of variance was explained by activities $(15 \%)$, followed by geographic variables $(13 \%)$, environmental variables $(11 \%)$, population $(8 \%)$, and interactions among all variables $(5 \%)$ (Fig. 3.3).

Seasonal RDA and partial RDA results indicated that the effects of activities were most strongly apparent in the pre-rainy season and much less apparent in the rainy season. Activities accounted for $24 \%$ of variance in the pre-rainy season (the most of any predictor categories) and for $15 \%$ in the rainy season (Fig. 3.4). The proportion of variance explained by environmental variables and population also decreased in the rainy season (from $16 \%$ to $15 \%$ and from $12 \%$ to $9 \%$, respectively), while the interaction term increased (from $<1 \%$ to $8 \%$; Fig. 3.4). Across both seasons, the amount of variance explained by geographic variables remained the same (18\%; Fig. 3.4).

When comparing RDA results with and without the suite of activities, it is clear that activities greatly enhanced explanatory power, with the full suite of predictors explaining $51 \%$ of variance and the suite of predictors without activities explaining $36 \%$ of variance. Geography and population explained less variance in the absence of activities, most likely due to some co-linearity of these predictors with activity predictors. In partial RDA without activity predictors, geography explained $5 \%$ of variance, 
environment explained $11 \%$, population explained $11 \%$, interaction terms explained $13 \%$, and $64 \%$ of variance remained unexplained (Fig. 3.5).

\section{Discussion}

The aim of this study was to determine the relative effects of natural and anthropogenic variables on reef health and identify the human activities most detrimental to reef health and in most need of management, using the reefs of the Comoros as a case study. Not only did inclusion of activities greatly improve explanatory power of predictors in RDA, activities were identified as the most influential suite of predictors for reef health, including the activities of men's fishing, sand extraction, and beachfront development. Other studies that include a single activity or a cumulative assessment of activities as predictors of fish assemblages or reef health have similar or lower explanatory power (e.g. Pinca et al. 2012; Sala et al. 2012).

Among anthropogenic factors, men's fishing and population most strongly related to poor coral cover and low fish richness, abundance, and biomass. These findings are consistent with other studies (e.g., Russ and Alcala 1989; McClanahan 1994; Williams et al. 2008; Stallings 2009). While some studies have found that market distance or socioeconomic development have strong relationships with fish size, biomass, and trophic level (e.g., Cinner and McClanahan 2006; Cinner et al. 2009), population was a stronger predictor than market distance in our analysis and the level of socioeconomic development across the study sites was too similar to test its influence on reef health. The influence of population in this study is supported by a study of fishery closures in the Western Indian Ocean region that found population (along with level of infringement) as the strongest predictor of change in fish biomass (Daw et al. 2011). 
Partial RDA results indicate that relationships between activities and reef health were partly masked by seasonal and natural variability within and among sites. The primary differences between seasons were in fish richness, abundance, and biomass (Fig. 3.1). Seasonal variability may be overcome with more concerted sampling effort at sites with high spatial heterogeneity in coral and fish variables and with long-term monitoring of temporal patterns. While many causes of temporal variation in fish populations have been identified (see Nguyen 2012 and references therein), the increases observed in this study are most likely due to: 1) decreased fishing effort during the rainy season when heavy rains were more frequent; 2) switching of fishing effort during the rainy season to pelagic and other non-reef associated species (Coordination des Comores 1996; pers. obs.), and/or 3) increases in recruitment during the rainy season corresponding with periods of peak larval fish abundance documented in the region (Kaunda-Arara et al. 2009). Due to these seasonal differences, detection of anthropogenic effects on reef health could be improved with data collection in the same season over multiple years. Island and site orientation along the coast also explained differences in reef health among sites. Sea temperature, currents, and nutrient flows are likely factors contributing to both geographic and temporal patterns of reef health (e.g. Andrews and Gentien 1982; Choat et al. 1988; West and Salm 2003; Sala et al. 2012).

Further evidence and understanding of the direct effects of activities at specific reef sites can be obtained over time and with additional research. There are likely to be differences in drivers of reef health across sites and continued monitoring would facilitate identification of key drivers of reef health at the site level. For example, intensive sand extraction has occurred at a few sites and is likely the key driver of poor reef health at 
those sites, but less influential at sites where extraction has ceased or is less intense (pers. obs.).

Study of sedimentation rates at reef sites with known sand extraction levels could provide further insight on the relative effects of sand extraction on reef health and may provide evidence of a causal relationship. Causal relationships are commonly studied when examining effects of fishing on reef health (e.g. Jennings and Polunin 1996; Mumby et al. 2006) and have been applied to investigations of agriculture and reef health (Fabricius and De'ath 2004). I attempted study of sedimentation rates during our fieldwork and although technical complications prevented reliable data collection, I recommend study of sedimentation rates as further investigation into the effects of activities on reef health. Another unexamined source of variance that may further explain reef health in some locations is freshwater output and terrestrial runoff deposition on reefs. I noted freshwater outlets near some reef study sites but did not include this variable in the analysis due to insufficient information on freshwater output across sites and seasons.

This study identified key human activities most influential on reef health and in most urgent need of management in a nation vulnerable to coral reef degradation. I recommend that the Comoros islands and other nations where reefs face similar anthropogenic pressures implement beach protection from sand extraction and fishery closure areas or regulate beach and marine resource use in an adaptive management approach as an effective way to enhance knowledge of the effects of specific activities on reef health. The adaptive management process allows managers and scientists to observe what management practices can best mitigate negative effects of human activities and 
improve reef health. Recommended management strategies for the Comoros include testing the use of fishery closure areas, beach closures and sanctions for sand extraction, and zoning areas for coastal development.

Studies of effects of human activities on reef health are sparse for the world's most diverse and vulnerable reefs and limit our ability to effectively manage many coral reefs. Furthermore, most studies on factors driving reef health focus on biophysical variables or a single human activity. This study demonstrated an assessment of suites of human impacts and natural factors affecting reef health and an evaluation of the relative influence of these factors on reef health. Further study of mechanistic factors such as loss of predators or sedimentation rate and their effects on several variables indicative of reef health are necessary to improve management. A major research gap is in the study of effects of anthropogenic activities through pre- and post- assessments measuring reef health parameters using multiple measurements before and during/after an activity in the area affected by the activity (an "impact" area) and in a nearby area with similar conditions to the impact area, but free of the impact (a "control" area). While this type of monitoring may not be possible in all cases, where possible, it will greatly enhance our knowledge and understanding of the impacts of activities on reef health. Local coral reef management efforts that apply concerted research effort to understand anthropogenic effects on reef health will have the best chance of addressing the direct drivers of change and thereby maintain reef health over time. 
Table 3.1. Predictor variables studied

\begin{tabular}{|c|c|c|c|c|}
\hline Category & Variable & Method of data collection & $\begin{array}{l}\text { Included } \\
\text { in } \\
\text { analysis? }\end{array}$ & References \\
\hline Activity & $\begin{array}{l}\text { Women's } \\
\text { fishing }\end{array}$ & Interviews \&observations & No & $\begin{array}{l}\text { (fishing regardless of type): Roberts } \\
\text { 1995; Ahamada et al. 2002; Mumby et } \\
\text { al. 2006; McClanahan et al. } 2008\end{array}$ \\
\hline Activity & Men's fishing & Interviews \&observations & Yes & $\begin{array}{l}\text { (fishing regardless of type): Roberts } \\
\text { 1995; Ahamada et al. 2002; Mumby et } \\
\text { al. 2006; McClanahan et al. } 2008\end{array}$ \\
\hline Activity & $\begin{array}{l}\text { Coral } \\
\text { extraction }\end{array}$ & Interviews \&observations & No & $\begin{array}{l}\text { Dulvy et al. 1994; Ahamada et al. 2002; } \\
\text { Guzmán et al. } 2003\end{array}$ \\
\hline Activity & Sand extraction & Interviews \&observations & Yes & $\begin{array}{l}\text { Huber and Meganck 1990; Ahamada et } \\
\text { al. } 2002\end{array}$ \\
\hline Activity & $\begin{array}{l}\text { Beachfront } \\
\text { housing and } \\
\text { development }\end{array}$ & Interviews \&observations & Yes & $\begin{array}{l}\text { Pastorok and Bilyard 1985; Ahamada et } \\
\text { al. 2002; Crabbe and Smith 2005; } \\
\text { Reopanischkul et al. 2009; Wolanski et } \\
\text { al. } 2009\end{array}$ \\
\hline Activity & $\begin{array}{l}\text { Motorized boat } \\
\text { transportation } \\
\text { launching from } \\
\text { reef site }\end{array}$ & Interviews \&observations & No & $\begin{array}{l}\text { Ahamada et al. 2002; Burgin and } \\
\text { Hardiman } 2011\end{array}$ \\
\hline Activity & Tourism & Interviews \&observations & No & $\begin{array}{l}\text { Hawkins and Roberts 1994; Ahamada et } \\
\text { al. } 2002\end{array}$ \\
\hline Activity & Agriculture & Interviews \&observations & No & $\begin{array}{l}\text { Ahamada et al. 2002; Fabricius and } \\
\text { De'ath } 2004\end{array}$ \\
\hline Geographic & Island & Map & Yes & \\
\hline
\end{tabular}


Table 3.1. continued

\begin{tabular}{|c|c|c|c|c|}
\hline Geographic & $\begin{array}{l}\text { Coastline } \\
\text { orientation }\end{array}$ & $\begin{array}{l}\text { Determined from map the cardinal direction } \\
\text { the coastline faced at each site - recorded in } \\
\text { degree equivalents for North }(0) \text {, Northeast } \\
\text { (45), East (90), Southeast (135), South (180), } \\
\text { Southwest (225), West (270), Northwest (315) }\end{array}$ & Yes & \\
\hline Geographic & Latitude & GPS coordinate at each site & No & Sala et al. 2012 \\
\hline Geographic & Longitude & GPS coordinate at each site & No & Sala et al. 2012 \\
\hline Environmental & $\begin{array}{l}\text { Adjacent } \\
\text { habitat }\end{array}$ & $\begin{array}{l}\text { Reef observation - identified habitats } \\
\text { surrounding each reef }\end{array}$ & No & $\begin{array}{l}\text { Nagelkerken et al. 2002; Mumby et al. } \\
\text { 2004; Dorenbosch et al. } 2007\end{array}$ \\
\hline Environmental & Depth & $\begin{array}{l}\text { Reef observation }- \text { estimated depth during } \\
\text { survey as }<1 \mathrm{~m},>1-2 \mathrm{~m},>2-3 \mathrm{~m},>3 \mathrm{~m}\end{array}$ & Yes & McGehee 1994 \\
\hline Environmental & $\begin{array}{l}\text { Distance to } \\
\text { mangroves }\end{array}$ & $\begin{array}{l}\text { Reef observation - estimated distance as } \\
<50 \mathrm{~m}, 50-100 \mathrm{~m},>100-1000 \mathrm{~m},>1000 \mathrm{~m}\end{array}$ & No & $\begin{array}{l}\text { Nagelkerken et al. 2002; } \\
\text { Mumby et al. 2004; Olds et al. } 2012\end{array}$ \\
\hline Environmental & $\begin{array}{l}\text { Distance to } \\
\text { seagrass }\end{array}$ & $\begin{array}{l}\text { Reef observation }- \text { estimated distance as } \\
<50 \mathrm{~m}, 50-100 \mathrm{~m},>100-1000 \mathrm{~m},>1000 \mathrm{~m}\end{array}$ & No & $\begin{array}{l}\text { Nagelkerken et al. 2002; Dorenbosch et } \\
\text { al. 2005; Olds et al. } 2012\end{array}$ \\
\hline Environmental & $\begin{array}{l}\text { Number of } \\
\text { days since first } \\
\text { sampling day }\end{array}$ & $\begin{array}{l}\text { Reef observation - recorded number of days } \\
\text { between first survey at first reef site and the } \\
\text { current survey }\end{array}$ & Yes & Letourneur 1996; Nguyen 2012 \\
\hline Environmental & $\begin{array}{l}\text { Number of } \\
\text { transects } \\
\text { resampled in } \\
\text { rainy season }\end{array}$ & $\begin{array}{l}\text { Reef observation - recorded number of } \\
\text { transects placed during pre-rainy season } \\
\text { surveys that were resampled during rainy } \\
\text { season surveys }\end{array}$ & No & \\
\hline Environmental & Rugosity & $\begin{array}{l}\text { Reef observation - average of three } \\
\text { measurements of } 1 \mathrm{~m} \text { rope length / length } \\
\text { along substrate when rope is fitted to reef } \\
\text { contours }\end{array}$ & Yes & Luckhurst and Luckhurst 1978 \\
\hline
\end{tabular}




\begin{tabular}{|l|l|l|l|l|}
\hline \multicolumn{2}{|l|}{ Table 3.1. continued } & $\begin{array}{l}\text { Reef observation - recorded whether survey } \\
\text { was in pre-rainy season or rainy season }\end{array}$ & $\begin{array}{l}\text { Only } \\
\text { qualitative }\end{array}$ & Letourneur 1996; Nguyen 2012 \\
\hline Environmental & Season & $\begin{array}{l}\text { Reef observation - see description in methods } \\
\text { section }\end{array}$ & No & $\begin{array}{l}\text { (sedimentation and turbidity): Rogers } \\
\text { 1979; Amesbury 1981; Rogers 1990; } \\
\text { Kleypas 1996 }\end{array}$ \\
\hline Environmental & Visibility & $\begin{array}{l}\text { Reef observation - estimated wave action } \\
\text { during survey as none, slight, moderate, or } \\
\text { strong }\end{array}$ & No & McGehee 1994 \\
\hline Environmental & Wave & Map & No & Cinner \& McClanahan 2006 \\
\hline Anthropogenic & $\begin{array}{l}\text { Distance to } \\
\text { major market }\end{array}$ & $\begin{array}{l}2003 \text { census data (Comoros government } \\
\text { unpubl.data) }\end{array}$ & Yes & Williams et al. 2008; Stallings 2009 \\
\hline Anthropogenic & Population
\end{tabular}


Table 3.2. Activity variables and scoring

\begin{tabular}{|c|c|}
\hline Attribute & Score \\
\hline Women's fishing & $\begin{array}{l}0=\text { none } \\
1=\text { yes with strong management (rules respected by all, } \\
\text { community is involved in management) } \\
2=\text { yes with moderate management (rules mostly } \\
\text { respected or not respected only by outsiders, } \\
\text { community may or may not be involved in } \\
\text { management) } \\
3=\text { yes with weak management (rules exist but poorly } \\
\text { enforced, community may or may not be involved in } \\
\text { management) } \\
4=\text { yes with no management }\end{array}$ \\
\hline Men's fishing & see Women's fishing (above) \\
\hline Coral extraction & $\begin{array}{l}0=\text { none } \\
1=\text { some }\end{array}$ \\
\hline Sand extraction & $\begin{array}{l}0=\text { none since } 20 \text { years or more } \\
1=\text { none since } 10-19 \text { years ago } \\
2=\text { none since } 2-9 \text { years ago } \\
3=\text { none since less than } 2 \text { years ago } \\
4=\text { yes with strong management (rules respected by all, } \\
\text { community is involved in management) } \\
5=\text { yes with moderate management (rules mostly } \\
\text { respected or not respected only by outsiders, } \\
\text { community may or may not be involved in } \\
\text { management) } \\
6=\text { yes with weak management (rules exist but poorly } \\
\text { enforced or payment only, community may or may not } \\
\text { be involved in management) } \\
7=\text { yes with no management }\end{array}$ \\
\hline $\begin{array}{l}\text { Beachfront housing and } \\
\text { development }\end{array}$ & $\begin{array}{l}0=\text { no housing } \\
1=\text { little housing } \\
2=\text { decreasing housing } \\
3=\text { housing present with no change } \\
4=\text { increasing; development }\end{array}$ \\
\hline $\begin{array}{l}\text { Transport by motorized boat } \\
\text { from reef site }\end{array}$ & $\begin{array}{l}0=\text { none } \\
1=\text { little } \\
2=\text { decreasing } \\
3=\text { some with no change } \\
4=\text { increasing }\end{array}$ \\
\hline Tourism & See Transport by motorized boat (above) \\
\hline Agriculture & See Transport by motorized boat (above) \\
\hline
\end{tabular}




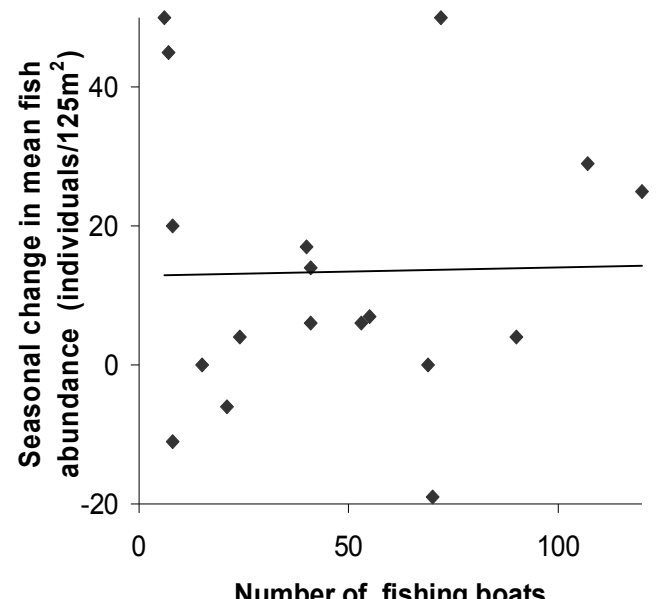

a)

Number of fishing boats

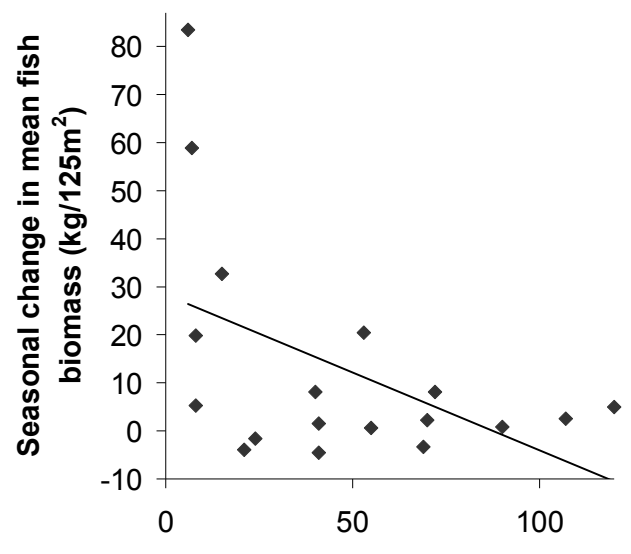

b)

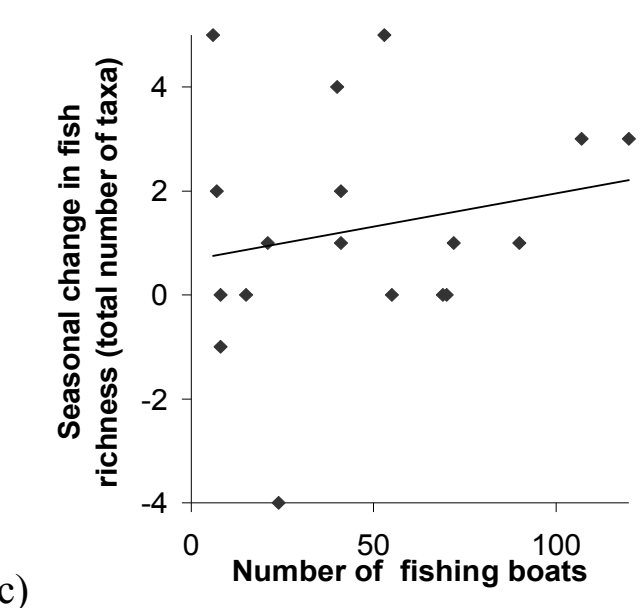

c)

Figure 3.1. Seasonal changes in fish abundance, biomass, and richness. Linear regressions of rainy season to pre-rainy season differences in a) fish abundance $\left(\mathrm{r}^{2}=0.0004, \mathrm{p}=0.93\right)$, b) fish biomass $\left(\mathrm{r}^{2}=0.234, \mathrm{p}=0.04\right)$, and c) fish richness $\left(\mathrm{r}^{2}=0.0411\right.$, $\mathrm{p}=0.42)$. 


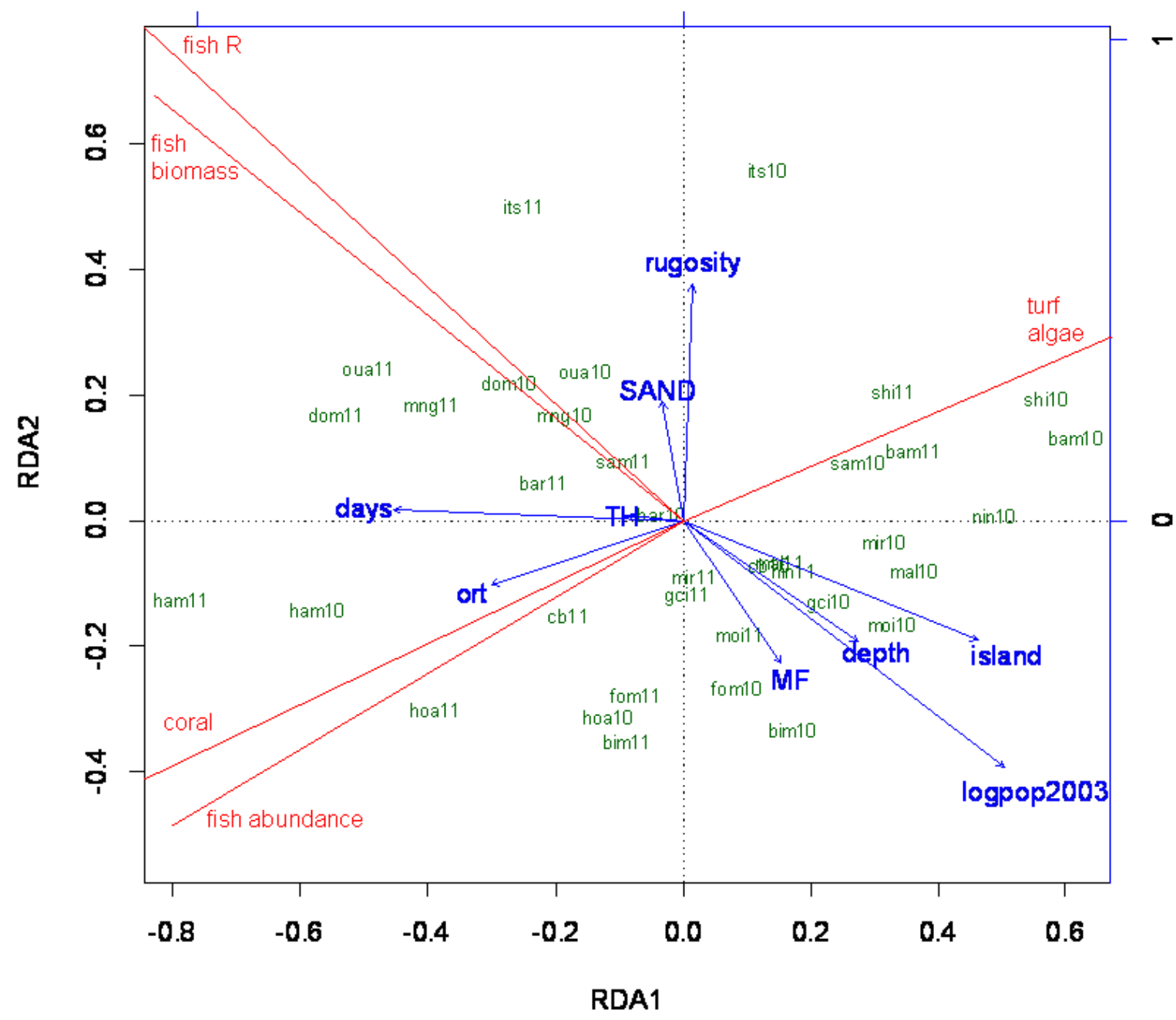

Figure 3.2. RDA plot (distance triplot) of reef health variables with respect to predictor variables. Predictor variables (in blue) include: number of days since first sampling day (days); depth; island; log of population from 2003 census (logpop2003); men's fishing (MF); coastline orientation (ort); rugosity; sand extraction (SAND); beachfront development $(\mathrm{TH})$. 


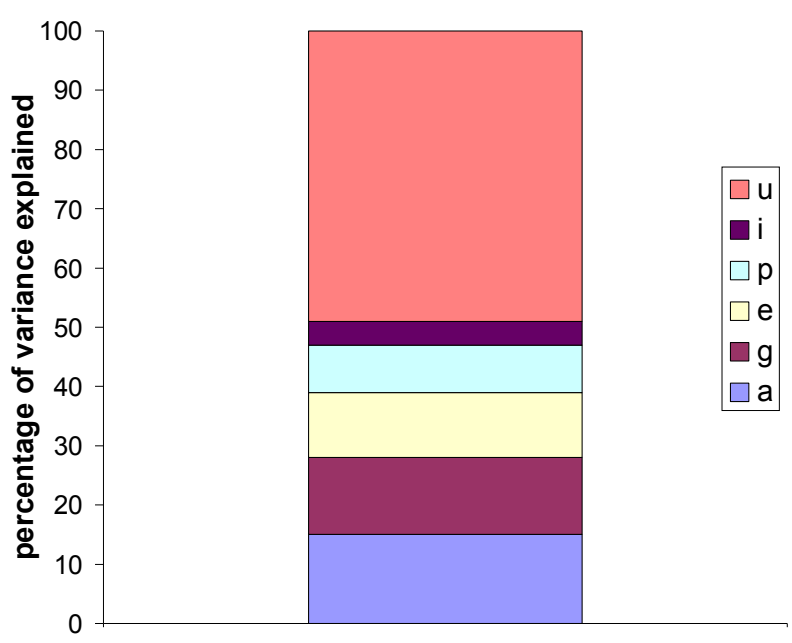

Figure 3.3. Partial RDA results. Variance explained by activity $(\mathrm{a} ; 15 \%)$, geographic (g; 13\%), environmental (e; 11\%), and population ( $\mathrm{p} ; 7 \%$ ) variables and their interactions(i; 5\%), and unexplained variance $(\mathrm{u} ; 49 \%)$.

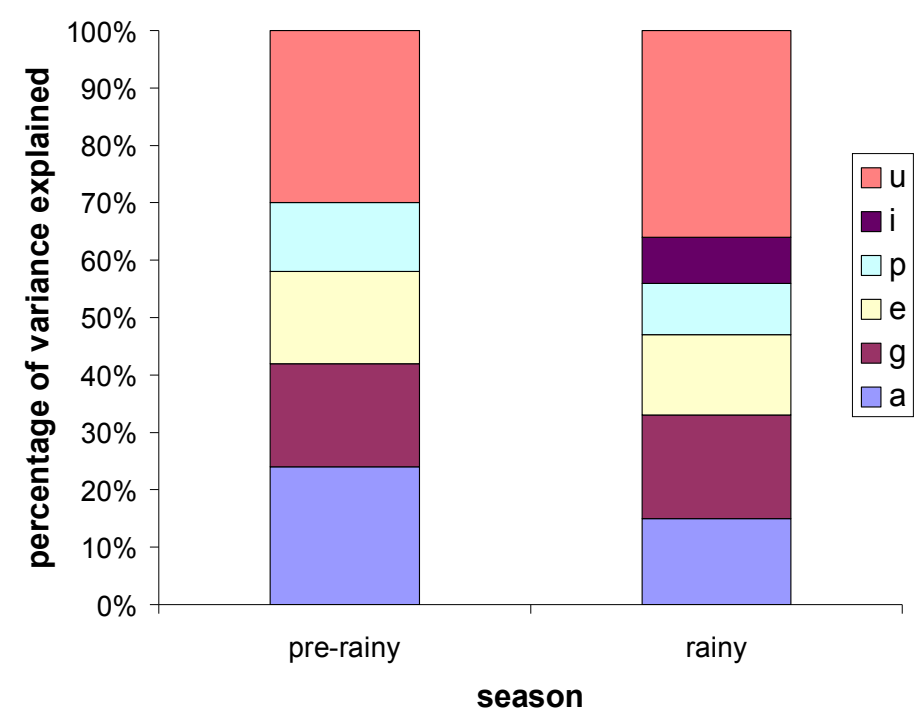

Figure 3.4. Partial RDA results by season. Proportion of variance explained by activity (a; pre-rainy: $24 \%$; rainy: 15\%), geographic (g; pre-rainy: $18 \%$; rainy: $18 \%$ ), environmental (e; pre-rainy: 16\%; rainy: 15\%), and population (p; pre-rainy: $12 \%$; rainy: 9\%) variables and their interactions (i; pre-rainy: $<1 \%$; rainy: $8 \%$ ), and unexplained variance (u; pre-rainy: 30\%; rainy: 35\%). 


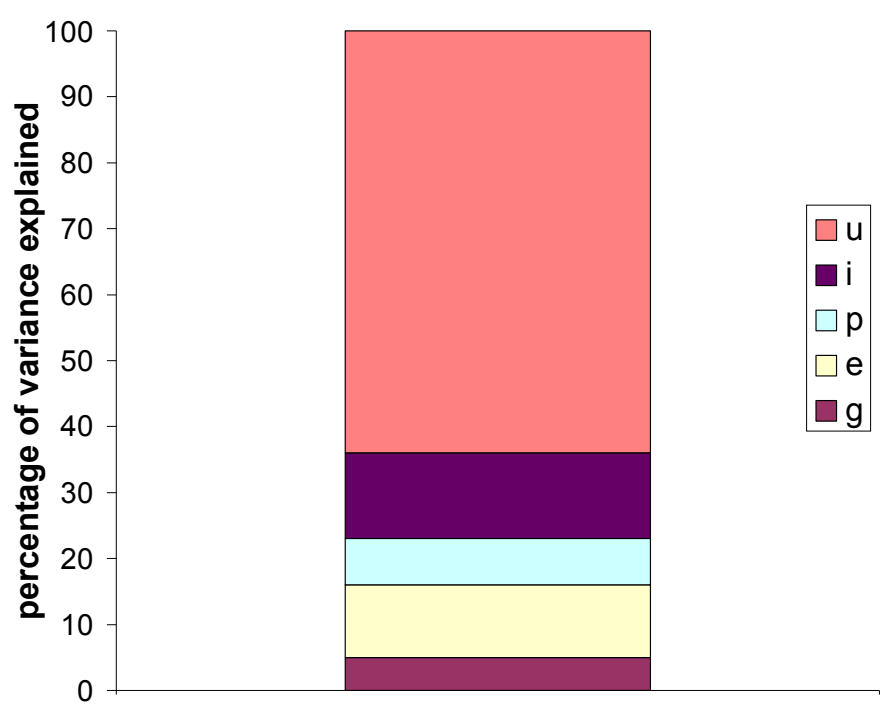

Figure 3.5. Results from partial RDA without activities. Variance explained by geographic $(\mathrm{g} ; 5 \%)$, environmental $(\mathrm{e} ; 11 \%)$, and population $(\mathrm{p} ; 7 \%)$ variables and their interactions $(\mathrm{i} ; 13 \%)$, and unexplained variance $(\mathrm{u} ; 64 \%)$. 


\section{Literature Cited}

Ahamada, S., L. Bigot, J. Bijoux, J. Maharavo, S. Meunier, M. Moyne-Picard, and N. Paupiah. 2002. Status of the coral reefs of the South West Indian Ocean island node: Comoros, Madagascar, Mauritius, Reunion and Seychelles. In Status of coral reefs of the world: 2002, ed. C. Wilkinson, 378pp. Queensland: Australian Institute of Marine Science.

Amesbury, S.S. 1981. Effects of turbidity on shallow-water reef fish assemblages in Truk, Eastern Caroline Islands. Proceedings of the Fourth International Coral Reef Symposium, Manila, 1:155-159.

Andrews, J.C. and P. Gentien. 1982. Upwelling as a source of nutrients for the Great Barrier Reef ecosystems: A solution to Darwin's question? Marine Ecology Progress Series 8: 257-269.

Bellwood, D.R., T.P. Hughes, C. Folke, and M. Nystrom. 2004. Confronting the coral reef crisis. Nature 429: 827-833.

Burgin, S. and N. Hardiman. 2011. The direct physical, chemical and biotic impacts on Australian coastal waters due to recreational boating. Biodiversity Conservation 20:683-701.

Burke, L., K. Reytar, M. Spalding, and A. Perry. 2011. Reefs at Risk Revisited. World Resources Institute, Washington, DC. 111p.

Choat, J.H., A.M. Ayling, and D.R. Schiel. 1988. Temporal and spatial variation in an island fish fauna. Journal of Experimental Marine Biology and Ecology. 121:91111. 
Cinner, J.E. and T.R. McClanahan. 2006. Socioeconomic factors that lead to overfishing in small-scale coral reef fisheries of Papua New Guinea. Environmental Conservation 33:73-80.

Cinner, J.E., T.R. McClanahan, T.M. Daw, N.A.J. Graham, J.Maina, S.K. Wilson, T.P. Hughes. 2009. Linking social and ecological systems to sustain coral reef fisheries. Current Biology 19:206-212.

Conand C., Chabanet P., Quod J.P., Bigot L. 1998. Manuel méthodologique pour le suivi del'état de santé des récifs coralliens du sud-ouest de l'Océan Indien. Mauritius : Commission Océan Indien. (In French).

Coordination des Comores. 1996. Bilan socio-économique et écologique de la zone côtière des Comores Enseignements et orientation pour les étapes suivantes. Mauritius : Commission Océan Indien. (In French).

Crabbe, J.M. and D.J. Smith 2005. Sediment impacts on growth rates of Acropora and Porites corals from fringing reefs of Sulawesi, Indonesia. Coral Reefs 24:437-441.

Daw, T.M., J.E. Cinner, T.R. McClanahan, N.A.J. Graham, S.K. Wilson. 2011. Design factors and socioeconomic variables associated with ecological responses to fishery closures in the Western Indian Ocean. Coastal Management 39:412-424.

Done, T.J. 1982. Patterns in the distribution of coral communities across the central Great Barrier Reef. Coral Reefs 1:95-107.

Dorenbosch, M., M.G.G. Grol, M.J.A. Christianen, I. Nagelkerken, G. van der Velde. 2005. Indo-Pacific seagrass beds and mangroves contribute to fish density and diversity on adjacent coral reefs. Marine Ecology Progress Series 302:63-76. 
Dorenbosch, M., W.C.E.P. Verberk, I. Nagelkerken, G. van der Velde. 2007. Influence of habitat configuration on connectivity between fish assemblages of Caribbean seagrass beds, mangroves and coral reefs. Marine Ecology Progress Series 334:103-116.

Dulvy, N.K., D.S. Stanwell-Smith, W.R.T. Darwall, C.J. Horrill. 1994. Coral mining at Mafia Island, Tanzania: A management dilemma. Ambio 24:358-365.

Emerick, C.M. and R.A. Duncan. 1982. Age progressive volcanism in the Comores Archipelago, western Indian Ocean and implications for Somali plate tectonics. Earth and Planetary Science Letters 60:415-428.

Fabricius, K.E. and G. De'ath. 2004. Identifying ecological change and its causes: a case study on coral reefs. Ecological Applications 14:1448-1465.

Fisher, R., B.T. Radford, N. Knowlton, R.E. Brainard, F.B. Michaelis, M.J. Caley 2011. Global mismatch between research effort and conservation needs of tropical coral reefs. Conservation Letters 4:64-72.

Garcia Charton, J.A., I.D. Williams, A. Perez Ruzafa, M. Milazzo, R. Chemello, C. Marcos, M.-S. Kitsos, A. Koukouras, S. Riggio. Evaluating the ecological effects of Mediterranean marine protected areas: habitat, scale and the natural variability of ecosystems. Environmental Conservation 27:159-178.

Garpe, K.C., S.A.S. Yahya, U. Lindahl, M.C. Ohman. 2006. Long-term effects of the 1998 coral bleaching event on reef fish assemblages. Marine Ecology Progress Series 315:237-247.

Graham N.A.J., T.R. McClanahan, M.A. MacNeil, S.K. Wilson, N.V.C. Polunin, S. Jennings, P. Chabanet, S. Clark, M.D. Spalding, Y. Letourneur, L. Bigot, R. 
Galzin, M.C. Ohman, K.C. Garpe, A.J. Edwards, C.R.C. Sheppard. 2008. Climate warming, Marine Protected Areas and the ocean-scale integrity of coral reef ecosystems. PLoS ONE 3(8): e3039. doi:10.1371/journal.pone.0003039.

Guzman, H.M., C. Guevara, A. Castillo. 2003. Natural disturbances and mining of Panamanian coral reefs by indigenous people. Conservation Biology 17:13961401.

Halpern, B.S., S. Walbridge, K.A. Selkoe, C.V. Kappel, F. Micheli, C. D’Agrosa, J.F. Bruno, K.S. Casey, C. Ebert, H.E. Fox, R. Fujita, D. Heinemann, H.S. Lenihan, E.M.P. Madin, M.T. Perry, E.R. Selig, M. Spalding, R. Steneck, R. Watson 2008. A global map of human impact on marine ecosystems. Science 319:948-952.

Halpern, B.S., C.V. Kappel, K.A. Selkoe, F. Micheli, C.M. Ebert, C. Kontgis, C.M. Krain, R.G. Martone, C. Shearer, S.J. Teck 2009. Mapping cumulative human impacts to California Current marine ecosystems. Conservation Letters 2:138148.

Hawkins, J.P. and C.M. Roberts. 1994. The growth of coastal tourism in the Red Sea: Present and future effects on coral reefs. Ambio 23:503-508.

Hoegh-Guldberg, O., P.J. Mumby, A.J. Hooten, R.S. Steneck, P. Greenfield, E. Gomez, C.D. Harvell, P.F. Sale, A.J. Edwards, K. Caldeira, N. Knowlton, C.M. Eakin, R. Iglesias-Prieto, N. Muthiga, R.H. Bradbury, A. Dubi, M.E. Hatziolos. 2007. Coral reefs under rapid climate change and ocean acidification. Science 318:1737-1742.

Huber, R.M. and R. Meganck 1990. The management challenge of Grand Anse beach erosion, Grenada, West Indies. Ocean \& Shoreline Management 13:99-109. 
Hughes, T. P., M. J. Rodrigues, D. R. Bellwood, D. Ceccarelli, O. Hoegh-Guldberg, L. McCook, N. Moltschaniwskyj, M. S. Pratchett, R. S. Steneck, and B. Willis. 2007. Phase Shifts, Herbivory, and the Resilience of Coral Reefs to Climate Change. Current Biology 17: 360-365.

Jeninngs, S. and N.V.C. Polunin. 1996. Effects of fishing effort and catch rate upon the structure and biomass of Fijian reef fish communities. Journal of Applied Ecology $33: 400-412$.

Jolliffe, I.T. 1986. Principal Component Analysis. New York: Springer-Verlag. 246p.

Kaufman, L., S. Sandin, E. Sala, D. Obura, F. Rohwer, T Tschirky. 2011. Coral Health Index (CHI): measuring coral community health. Science and Knowledge Division, Conservation International, Arlington, VA, USA. 15pp.

Kaunda-Arara, B., J.M. Mwaluma, G.A. Locham, V. Oresland, M.K. Osore. 2009. Temporal variability in fish larval supply to Malindi Marine Park, coastal Kenya. Aquatic Conservation: Marine and Freshwater Ecosystems 19:S10-S18.

Klein C.J., N.C. Ban, B.S. Halpern, M.Beger, E.T. Game, H.S. Grantham, A. Green, T.J. Klein, S. Kininmonth, E. Treml, K. Wilson, H.P. Possingham. 2010. Prioritizing land and sea conservation investments to protect coral reefs. PLoS ONE 5(8): e12431. doi:10.1371/journal.pone.0012431.

Kleypas, J.A. 1996. Coral reef development under naturally turbid conditions: fringing reefs near Broad Sound, Australia. Coral Reefs 15:153-167.

Letourneur, Y. 1996. Dynamics of fish communities on Reunion fringing reefs, Indian Ocean. II Patterns of temporal fluctuations. Journal of Experimental Marine Biology and Ecology 195:31-52. 
Luckhurst, B.E. and K. Luckhurst. 1978. Analysis of the influence of substrate variables on coral reef fish communities. Marine Biology 49:317-323.

McClanahan, T.R. 1994. Kenyan coral reef lagoon fish: Effects of fishing, substrate complexity, and sea urchins. Coral Reefs 13:231-241.

McClanahan, T.R. 2008. Response of the coral reef benthos and herbivory to fishery closure management and the 1998 ENSO disturbance. Oecologia 155:169-177.

McClanahan, T.R. (editor) 2008. Manual and Field Guide for Monitoring Coral Reef Ecosystems, Fisheries, and Stakeholders. Wildlife Conservation Society, New York.

McClanahan, T.R., C.C. Hicks, and E.S. Darling. 2008. Malthusian overfishing and efforts to overcome it on Kenyan coral reefs. Ecological Applications 18:15161529.

McGehee, M.A. 1994. Correspondence between assemblages of coral reef fishes and gradients of water motion, depth, and substrate size off Puerto Rico. Marine Ecology Progress Series 105:243-255.

Michener, W.K. 2008. Quantitatively evaluating restoration experiments: research design, statistical analysis, and data management considerations. Restoration Ecology 5:324-337.

Moberg, F. and C. Folke. 1999. Ecological goods and services of coral reef ecosystems. Ecological Economics 29:215-233.

Mumby, P.J., A.J. Edwards, J.E. Arias-Gonzalez, K.C. Lindeman, P.G. Blackwell, A. Gall, M.I. Gorczynska, A.R. Harborne, C.L. Pescod, H. Renken, C.C.C. Wabnitz, 
G. Llewellyn. 2004. Mangroves enhance the biomass of coral reef fish communities in the Caribbean. Nature 427:533-536.

Mumby, P.J., C.P. Dahlgren, A.R. Harborne, C.V. Kappel, F. Micheli, D.R. Brumbaugh, K.E. Holmes, J.M. Mendes, K. Broad, J.N. Sanchirico, K. Buch, S. Box, R.W. Stoffle, A.B. Gill. 2006. Fishing, trophic cascades, and the process of grazing on coral reefs. Science 311:98-101.

Munday P.L. 2004. Habitat loss, resource specialization, and extinction on coral reefs. Global Change Biology 10:1642-1647.

Nagelkerken, I., C.M. Roberts, G. van der Velde, M. Dorenbosch, M.C. van Riel, E. Cocheret de la Moriniere, P.H. Nienhuis. 2002. How important are mangroves and seagrass beds for coral-reef fish? The nursery hypothesis tested on an island scale. Marine Ecology Progress Series 244:299-305.

Nguyen, L.V. 2012. Temporal dynamics of coral reef fish communities in Nha Trang Bay marine protected area, South-Central Vietnam. Environmental Biology of Fishes 93:277-293.

Nystrom, M., C. Folke, and F. Moberg 2000. Coral reef disturbance and resilience in a human-dominated environment. Trends in Ecology \& Evolution 15:413-417.

Ohman, M.C., A. Rajasurya, O. Linden 1994. Human Disturbances on Coral Reefs in Sri Lanka: A Case Study. Ambio 22:474-480.

Olds, A.D., R.M. Connolly, K.A. Pitt, P.S. Maxwell. 2012. Primacy of seascape connectivity effects in structuring coral reef assemblages. Marine Ecology Progress Series 462:191-203. 
Pastorok, R. A., and G. R. Bilyard. 1985. Effects of Sewage Pollution on Coral Reef Communities. Marine Ecology Progress Series 21: 175-189.

Pinca, S., M. Kronen, F. Magron, B. McArdle, L. Vigliola, M. Kulbicki, S. Andrefouet. 2012. Relative importance of habitat and fishing in influencing reef fish communities across seventeen Pacific Island Countries and Territories. Fish and Fisheries 13:361-379.

Reopanichkul, P., T. A. Schlacher, R. W. Carter, and S. Worachananant. 2009. Sewage Impacts Coral Reefs at Multiple Levels of Ecological Organization. Marine Pollution Bulletin 58: 1356-1362.

Roberts, C.M. 1995. Effects of fishing on the ecosystem structure of coral reefs. Conservation Biology 9:988-995.

Rogers, C.S. The effect of shading on coral reef structure and function. Journal of Experimental Marine Biology and Ecology 41:269-288.

Rogers, C.S. 1990. Responses of coral reefs and reef organisms to sedimentation. Marine Ecology Progress Series 62:185-202.

Ruckleshaus, M., T. Klinger, N. Knowlton, and D.P. DeMaster 2008. Marine ecosystembased management in practice: Scientific and governance challenges. BioScience 58:53-63.

Russ, G.R. and A.C. Alcala. 1989. Effects of intense fishing pressure on an assemblage of coral reef fishes. Marine Ecology Progress Series 56:13-27.

Sala, E., E. Ballesteros, P. Dendrinos, A. Di Franco, F. Ferretti, D. Foley, S. Fraschetti, A. Friedlander, J. Garrabou, H. Guclusoy, P. Guidetti, B.S. Halpern, B. Hereu, A.A. Karamanlidis, Z. Kizilkaya, E. Macpherson, L. Mangialajo, S. Mariani, F. 
Micheli, A. Pais, K. Riser, A.A. Rosenberg, M. Sales, K.A. Selkoe, R. Starr, F. Tomas, M. Zabala. 2012. The structure of Mediterranean rocky reef ecosystems across environmental and human gradients, and conservation implications. PLoS ONE 7(2): e32742. doi:10.1371/journal.pone.0032742

Stallings, C.D. 2009. Fishery-independent data reveal negative effect of human population density on Caribbean predatory fish communities. PLOS ONE 4(5): e5333. doi:10.1371/journal.pone. 0005333 .

Underwood, A.J. 1994. On beyond BACI: sampling designs that might reliably detect environmental disturbances. Ecological Applications 4:3-15.

West, J.M. and R.V. Salm. 2003. Resistance and resilience to coral bleaching: Implications for coral reef conservation and management. Conservation Biology 17:956-967.

Wilkinson, C. Ed. 2004. Status of Coral Reefs of the World. Global Coral Reef Monitoring Network, Townsville, Australia.

Williams, I.D., W.J. Walsh, R.E. Schroeder, A.M. Friedlander, B.L. Richards, K.A. Stamoulis. 2008. Assessing the importance of fishing impacts on Hawaiian coral reef fish assemblages along regional-scale human population gradients. Environmental Conservation 35:261-272.

Wolanski, E., J.A. Martinez, R.H. Richmond 2009. Quantifying the impact of watershed urbanization on a coral reef: Maunalua Bay, Hawaii. Estuarine, Coastal and Shelf Science 84:259-268.

Zuur, A.F., E.N. Ieno, and G.M. Smith 2007. Analysing Ecological Data. Springer, New York: 648pp. 
Chapter 4. Effective co-management through community and meta-community roles in coral reef fishery management in the Comoros

\section{Abstract}

I conducted a qualitative study of co-managed coral reef fisheries in the Comoros to identify the roles of community, government, and external agents in effective comanagement. The study also compared community and government roles in comanagement arrangements inside and outside a Marine Protected Area (MPA). I conducted stakeholder interviews in 21 villages to investigate attributes of fishery comanagement and perceptions of governance and the state of the fishery. Our findings indicate the importance of community and 'meta-community' involvement in governance, initiated through education and capacity building and supported by government and external agents. Although resilient governance was achieved through similar means both inside and outside the MPA, low community participation resulted in ineffective governance only outside the MPA. Social cohesion, learning, and adaptability are three likely factors necessary for communities to develop the strong institutions found at sites with resilient governance and I recommend further investigation into these and other factors to ensure effective and enduring co-management.

\section{Introduction}

Small-scale fisheries in developing countries are a significant and valuable component of world fisheries, yet remain largely undocumented and unrecognized. Recent estimations place 97\% (36 million) of the world's fishers in developing countries and an estimated $88 \%$ (107million) of the world's fishery and fish trade workers employed in the small-scale sector in developing countries (Mills et al. 2011). Small- 
scale fisheries produce $55 \%$ of total fisheries catch in developing countries and $62 \%$ of total developing country fisheries production is used for local consumption (Mills et al. 2011). Experts and managers familiar with fisheries in developing countries have long suspected the importance of small-scale fisheries (e.g. Mahon 1997), yet a lack of data has distorted views of the fisheries sector, undervaluing the economic, food security, and livelihood contribution of small-scale fisheries at national and regional scales (Mills et al. 2011).

Just as gathering data on widespread small-scale fishery practices has proven difficult, finding appropriate methods for managing these fisheries has been equally challenging due to their heterogeneity and the large number and diversity of threats they face. The variety of activities, use patterns, actors, organizational levels, and economic markets encompassed in the classification of small scale-fisheries leaves only the "labour intensive harvesting, processing, and distribution technologies" employed as their unifying feature (FAO 2005). Features of small-scale fisheries that make management difficult include: a diversity of participants, catch methods, and fish species targeted; complexity of social and ecological contexts; and scale (Berkes et al. 2001; Berkes 2003). Threats to small-scale fisheries include: industrialized large-scale fishing and global overfishing (Pauly et al. 2002); localized overfishing from growing population, economic need, and entry into new markets; and pollution and climate change (Sadovy 2005).

Fisheries can be described as a common pool resource: multiple persons can access it; it can be degraded by overuse; one person's use subtracts from resource availability to others; and exclusion or organization to safeguard the resource costs time and/or resources (Dietz et al. 2002). Common Pool Resource (CPR) theory has been 
developed to explain how users of common pool resources might overcome costs to prevent overuse of the resource. The theory identifies attributes of the resource, resource users, and the governance system that facilitates enduring resource management (Schlager 2004). The attributes are considered conditions that increase likelihood of effective CPR governance, recognizing that each real-world CPR management case may rely on some attributes more than others or present additional attributes (Schlager 2004). The key assumption of CPR governance is that resource users are organized in some way to prevent overuse of the resource.

Co-management is a management approach that fits the assumption and attributes outlined in CPR theory and is a commonly recommended approach for managing smallscale fisheries in developing countries. The term 'co-management' describes the sharing of responsibility for management between a government and resource users (and possibly other 'external' actors such as non-governmental organizations) and encompasses a variety of arrangements with differing levels of participation and power-sharing roles for each actor (Sen and Nielsen 1996; Fig.1). Borrini-Feyerabend (2010) defines and differentiates co-management into two processes: co-management and shared governance. Multiple actors, usually a community or stakeholder group and a state government, participate in technical and practical matters of management actions (comanagement) and in decision-making processes and institutions (shared governance; Borrini-Feyerabend 2010). In this paper, I use the term co-management to refer to both the co-management and shared governance functions specified above. Co-management emphasizing community participation is advised for small-scale fisheries in developing countries because of a need for "overall community and economic development and 
social empowerment in addition to resource management" (Pomeroy and Rivera-Guieb 2006). A recent study of several co-managed small-scale fisheries found general improvement over time for income and well-being of resource users as well as fishery yield and resource access, indicating the benefits of co-management and achievement of positive social and ecological outcomes (Evans et al. 2011). While it is appropriate for communities to assume a key role in co-management due to limited government resources, communities must have the power, support, and capacity to fulfill their role (Pomeroy and Rivera-Guieb 2006). As co-management encompasses a broad range of participation and roles for the actors involved, negotiation between actors and mutual understanding of the roles each will play throughout the co-management process is essential (Borrini-Feyerabend 2010). Empirical investigations of the various roles and levels of participation with which a community or government can engage in comanagement are rare, but would greatly contribute to uniting co-management theory with practice. Through study of various permutations of community and government roles in a real-life co-management setting, we may begin to clarify the fundamental and complementary roles each actor must play for effective and enduring co-management. I conducted qualitative case studies of coral reef fishery management in the Comoros to evaluate the various roles of communities and governments in comanagement and identify cases of effective and resilient co-management. Qualitative approaches for data gathering and analysis are best suited in situations where social phenomena are poorly understood and/or when understanding the process and interactions that lead to certain outcomes is critical (Patton 2002). I also evaluated the influence of a Marine Protected Area (MPA) on community and government roles and 
governance effectiveness. I used CPR governance principles defined by Ostrom (1990) as a starting point to discern community and government roles in effective co-management and considered other emergent factors influencing governance effectiveness. I also investigated social perceptions and ecological attributes of the fishery in each case. Our goals were to identify effective combinations of community and government roles in comanagement and to determine whether and how a Marine Protected Area shapes roles of each actor.

Study Area

The reefs of the Comoros, located in the Mozambique Channel (Fig. 4.2a.), are an appropriate model for investigating community-based co-management of small-scale fisheries in developing countries. The country's social and ecological context reflects the situation of small-scale fisheries in many developing countries. Variation in comanagement arrangements among the small-scale fisheries within the Comoros allows an investigation of the roles of government and communities in effective co-management. The reefs of the Comoros are seldom subject to severe storms or crown of thorns outbreaks and have proven to be resilient to major coral bleaching events such as the 1998 event (Ahamada et al. 2002). The reefs studied consist mainly of fringing reefs with high hard coral diversity; I identified 23 scleractinian coral genera during the study, most often observing Acropora, Porites, Favites, Echinopora, and Goniastrea. The political background of the country largely influences environmental policy. The Comoros is a predominantly Sunni Muslim country and a former colony of France, gaining independence in 1975, and currently governed as a republic with a mixed legal system of Islamic religious law, French civil code of 1975, and customary law (CIA factbook 
2013). The country is made up of three islands, Grande Comore, Anjouan, and Moheli, with administrative functions conducted in one major city on each island (2 on Anjouan, the most populous island). While national legislation exists to protect biodiversity, coastal habitats, and key species, such laws receive little attention and enforcement; most environmental action is decentralized and occurs through community groups (Ahamada et al. 2002; Bigot et al. 2002). Support from external agents such as international nongovernmental organizations (NGOs) comes in the form of occasional project grants awarded for specific and short-term (usually 2-5 years) actions for environmental protection. Thus, a neo-traditional form of community-based co-management is practiced in most settlements and is the most consistent institution for environmental protection and resource management within the Comoros. Although local pressure on reefs can be high, most resource use is for subsistence with no major commercialization of reef products and virtually all reef-resource trade occurring solely within the country. The Comoros is highly dependent upon foreign aid and international trade, receiving income mainly through export of vanilla, cloves, and essential oil of ylang-ylang (CIA factbook 2013). The proliferation of community-based management with varying levels of governmental participation allows for investigation of the various roles community and governmental actors can play in co-management.

Since 2000, a co-managed Marine Protected Area (MPA) has governed the coral reefs of the southern half of Mohéli and is the only MPA in the Comoros. The project that undertook the design and creation of the Mohéli Marine Park (Parc Marin de Mohéli; PMM, Fig. 4.2b.) was a joint international-Comoran government effort that was wellfunded, primarily by the World Bank's Global Environment Facility (GEF), and benefited 
from the support and representation of a highly qualified team of experts from the Comoran government, the International Union for the Conservation of Nature (IUCN), and other international organizations, with the explicit and thorough involvement of citizens from local communities (Granek and Brown 2005). While baseline data is very sparse for the park, southern Moheli was selected as the park's location largely due to the high quality of the reef, habitat diversity, low level of coastal development, and community participation in environmental education and monitoring during previous US Peace Corps assignments (Granek and Brown 2005). Initial community involvement in park development included providing input on the location and delineation of 10 no-take areas within PMM, identification of types of fishing permitted within the PMM boundaries, and identifying a representative from each park community to serve as a trained 'ecoguard' and work under supervision of a locally recruited full-time park manager. After GEF support for PMM ended and a lapse in funding and deterioration of the park's formal administration occurred from 2006-2009, local leaders, ecoguards, and communities carried on with management in an adapted form, observing gear restrictions but not enforcing the delineated no-take areas. In 2009, PMM gained a short-term (2 year) source of funding and resumption of official management and search for continuing funding was underway. The sparse allocation of state resources and inconsistent external support available to PMM reflects the reality faced by many MPAs (co-managed or otherwise) in developing nations, which does not always impede achievement of ecological and social outcomes, and provides valuable insight into co-managed MPA effectiveness under typical conditions (see Hargreaves-Allen et al. 2011). 
Methods

Co-management relies upon stakeholder participation, fitting the CPR theory of stakeholder-based management. While principles used in institutional analysis vary from study to study (e.g. Cinner et al. 2009, Cox et al. 2010, Wamukota et al. 2012), the original CPR design principles described by Ostrom (1990) provide a strong starting point for identifying the respective roles of communities, government, and other comanagement actors and can be elaborated upon with further investigation. The design principles outline the attributes of robust governance (including co-management) and include: 1) boundaries and memberships for resource use; 2) resource use rules appropriate for resource and participants; 3) arenas for collective-choice concerning rules and the resource; 4) monitoring of the resource and its users; 5) graduated sanctions for rule infractions; 6) mechanisms for resolution of conflicts among resource users; 7) recognition of the rights of resource users to organize; and 8) nested units of governance. Empirical critiques of CPR theory focus on the limited contexts to which the principles apply and limited scope of factors investigated that are relevant to successful management, while theoretical critiques raise concern that the design principles will lead to a 'blueprint' approach to management that is oversimplified and devoid of context (Cox et al. 2010). Small-scale fisheries in developing countries fit well within the prescribed context of CPR governance. The scope of the principles is well suited to the goal of this study to identify the fundamental and complimentary roles of governance actors. Throughout the course of the study, I also remained open to consideration of emergent factors not included in CPR principles. 
Our unit of analysis for co-management was the village, the smallest social unit with formal governance corresponding to a reef patch or fishing area. I conducted semistructured interviews in 21 villages (referred to below as "sites") throughout the Comoros, six of which were within PMM, the only marine park in the country. Interviews from May to August 2009 focused on attributes of fishing practiced within each community (in addition to investigating other local activities, described in Chapter 3). Interviews from October 2010 through February 2011 focused on fishery management (and management of two additional activities). To gain insight on perceptions of the fishery and its management, interviews included questions on the importance of fishing for livelihood, perceptions of the condition of the fishery, perceptions of the condition and values of the coral reef habitat, and perspectives on management. I used open-ended questions to gather qualitative information, structured questions for information on specific fishery and management features and some quantitative data, and observations to verify interview findings. To gather information and perspectives from individuals most familiar with the topics, I selected interviewees on the basis of knowledge of the community and local fishing practices. I interviewed 4-16 individuals from each site through individual and single-gender group interviews. While sample size was low for the number of stakeholders in each village, I found interviewee agreement in responses to be much greater within than across villages. The low-sample size approach was chosen to: obtain in-depth information; suit cultural norms that require established relationships to obtain personal information and norms that encourage discussion, debate, and lengthy responses rather than short answers; and avoid participant burnout. I interviewed groups of single-gender in accordance with Muslim tradition and to encourage unreserved 
participation of interviewees. I conducted interviews in the local Comoran dialect with translation assistance from local field assistants. I conducted additional interviews in French with village association members and park staff from one village that had exceptional community-wide organization (Itsamia) to discuss their community organization and conservation efforts taking place in the community. To encourage candid participation of the interviewees, I hand-wrote all interview responses on site rather than recording and transcribing. I transcribed interview notes and coded them for attributes pertaining to CPR governance. The codes were used to identify emergent themes of fishery attributes, management practices, and stakeholder perceptions of the resource, habitat, and management. I collected data on ecological attributes using fish and coral surveys at each site in two seasons, the pre-rainy season in September-December 2010 and the rainy season in January-March 2011 to determine benthic cover, fish taxonomic richness, and fished species abundance, biomass, and biomass per fish.

I evaluated whether each CPR governance principle was utilized at each site (with categories of "absent", "weak", "moderately practiced", "fully practiced", or "unclear" if the principle could not be determined from data collected) and the role of community and government actors in carrying out each principle. I compared sites in terms of use of CPR principles, community and government actor roles, influence of PMM structure (where applicable), and overall governance effectiveness. I also identified aspects of management and governance practices that could be strengthened and consulted interviewee comments to make recommendations of how to improve management and governance. 
I highlight a few case studies to illustrate our overall findings, focusing on sites demonstrating the greatest or least effective governance. For each case study I describe CPR institutional performance, fishery and management perceptions, and ecological attributes. I also address whether CPR institutional performance corresponded with perceptions and ecological attributes and what factors might explain the observed patterns.

Results

Two sites were found to have effective and resilient governance, one within PMM and one on Anjouan. Five sites had ineffective governance, none of which were within PMM (Table 4.1). The remaining sites had moderately effective governance but had yet to experience a test of resilience and presented small variations in community and government roles in co-management. The role of government in co-management was largely a supporting one across most sites. Community participation in governance varied across sites and was strongest at sites with effective and resilient governance. PMM provided a meta-community structure and supported effective governance.

Effective governance tended to correspond with strong implementation of CPR principles, with the exception of boundaries and memberships, which were not well defined for any particular site. While lack of boundaries and memberships contributed to the deterioration or absence of other institutions at some sites, other sites maintained other institutions and prevented ineffective governance. The only well defined physical boundary, recognized by government and communities alike, was that of PMM. Some sites, such as Itsamia and Ouani, established de facto fishing territories through monitoring of fishing activities and thereby pressuring compliance of site-level rules, but 
did not claim exclusive fishing rights and did not exclude other fishers based on membership or boundaries. When interviewees were asked to identify the origins of nonlocal fishers who frequent local fishing areas, at least one neighboring village was reported by three sites (Miringoni, Chindini, Male), four or more neighboring and regional villages were reported by seven sites (Ouani, Shiroroni, Bambao, Bimbini, Nindri, Itsandra, Memboi Mboini), and neighboring islands as well as villages were reported by ten sites (Nioumachoi, Ndrondroni, Wanani, Itsamia, Ouallah I, Hamba, Barakani, Domoni, Hoani, Fomboni), indicating weak establishment of memberships and boundaries to resource access. The identification of who fished at local fishing sites was not clear from the interview at Moindzaza.

Among PMM sites, only two (Itsamia and Ndrondroni) had strong community participation in fishery governance. Itsamia had the strongest participation, with rules governing fishing decided upon by the community in addition to the rules established by PMM (see case study below). Both Itsamia and Ndrondroni fishers participated in collective choice arenas, monitoring, and exercising sanctions. The remaining sites (Nioumachoi, Miringoni, Ouallah I, and Wanani) had less community participation governance, relying on PMM for monitoring and sanctions, and not participating in a collective choice arena for decision-making. Despite weaker community participation, effective governance was maintained at all PMM sites as fishers recognized and adhered to the rules established by PMM, including visiting fishers from other regions.

A common feature among the sites with ineffective governance was the inability to convince all resource users to adhere to the rules, due to either poor cohesiveness of the resource users (e.g., Bambao, where some fishers felt disenfranchised by the fishers' 
association, saying there was no association to represent them; and Nindri where the fishers' association was organized at a 'commune' level, shared among six neighboring villages, and for which interviewees could not provide an estimation for the number of fishers involved) or overwhelming resource use by non-residents with little interest in the welfare of local fishers or in sustaining the resource (e.g., Bimbini, where interviewees cited frequent use of local fishing grounds by fishers from a nearby municipality where the number of fishers overwhelmed their own fishing grounds; Table 4.1).

Other factors contributing to ineffective governance varied from site to site. At Nindri, interviewees reported that fishing governance relies upon the municipal government and commune level organizations, that rule infractions were most common by fishers from other villages in the commune, and that net use occurred although it had been forbidden in the past. One interviewee commented that when a fisher used a net, sanctions were "...the responsibility of the city government, but they [the government officials] take the fish and share them with the fisherman" (translated by J. Mouhhidine). These statements indicated that governance institutions wavered with political will and organization and representation of the large community of fishers was inadequate. At Bimbini, interviewees reported that the police and judicial authority seated in a neighboring municipality discriminated against fishers from their village, indicating a lack of representation or advocacy for resource user rights at higher levels of authority. One interviewee stated, "they only catch fishers from our village for breaking the rules while it's them [the fishers from the municipality] that often break the rules" (translated by J. Mouhhidine). At Fomboni, interviewees reported the national syndicate of fishers associations as the governing body of their fishery, but the syndicate lacked resource use 
rules and means to monitor or enforce rules of any kind, indicating a lack of selfgovernance and a reliance on paper regulations and inactive state organization and enforcement. As one interviewee explained, "The syndicate decides the rules and we have difficulties with them" (translated by H. Youssoufi). At Domoni, the reasons for lack of governance institutions were unclear. Although the site had an active association of fishers, there were no rules pertaining to resource use.

Reefs at sites with ineffective governance were generally degraded with the majority of sites with ineffective governance falling below the median for live hard coral cover, fish taxonomic richness, and fished species abundance (rainy season only), biomass, and biomass per fish (Table 4.2). Poor perceptions of management corresponded to the poor performance at sites with ineffective governance (Table 4.3). Interviewees stated needs for awareness-raising, community motivation, respect of management by outsiders, local and national government support, and the need to stop destructive fishing practices and sand extraction as management priorities. Stated reef values were primarily material resources, such as the habitat it provided for fish and the sand it produced, but interviewees at two sites also mentioned non-extractive values of coastline protection and aesthetic value (Table 4.3). Interviewees at the sites with ineffective governance stated reef health as "poor", "degraded" or "improving", indicating awareness that current reef health was unsatisfactory, but with possible recovery at two sites (Table 4.3). Interviewees perceived the fishery as declining at four of the five sites, noting that fish were less abundant, could only be caught at more distant fishing grounds than in the past, and were of progressively smaller size over time (Table 4.3). Interviewees at one site noted periodic changes in fish stocks but no general changes 
over time. Fishing was the most important livelihood for interviewees at two sites, and of mixed importance along with other livelihoods for interviewees at three sites (Table 4.3). Case Study: Bimbini - The case of Bimbini illustrates many features contributing to ineffective governance. Fishers from surrounding villages and more distant municipalities frequent Bimbini waters for fishing. Bimbini fishers had established an agreement to refrain from net fishing, but failed to get compliance from visiting fishers. Net use is now common and no rules have been attempted since the effort to ban nets failed. An arena for collective action exists in which fishers participate in management decisions, but is organized within the village and does not include non-resident fishers that utilize the fishing grounds. While village-level collective action has been successful despite non-resident resource use at villages like Itsamia (case study below), the number of non-local fishers frequenting Bimbini is particularly large. In addition, the fishers' association that serves as the collective action arena for the Bimbini fishery is poorly organized. Interviewees disputed whether the association was in existence due to the fact that few fishers had membership in the association and the large proportion of members that did not contribute the required dues. Interviewee reports also revealed that the Bimbini fishery faces biased conflict resolution institutions and a lack of nested governance support as state power is seated in a neighboring municipality, Sima, and decisions from the courts in Sima tend to favor its own fishers when settling disputes with Bimbini fishers. A higher order collective action arena composed of a committee of fishers with representatives of each community that fished at Bimbini was attempted but unsuccessful. Sanctions were also unsuccessful, due to biased decisions favoring rulebreakers from Sima when they were brought in to the police and the courts, as reported 
by interviewees. In summary, Bimbini fishers are poorly organized and lack authority over their local fishing grounds and the support necessary to achieve this authority.

Interviewees acknowledged the importance of fishery management and the need to stop "destructive" fishing methods. They reported a need for stronger motivation for management within the community in addition to the need for non-residents to recognize local management. Interviewees reported they are aware of the degraded state of the reef, one noting "the state of the reef is very bad" and another saying that it is "no longer beautiful like before, there is sedimentation" (translated by J. Mouhhidine). Interviewees were aware of the value the reef has for coastline protection (Table 4.3). They reported the fishery is in decline due to sedimentation, fishing methods such as poison use, and overexploitation. Fishers participated in many occupations for their livelihoods (based on observation; Table 4.3). Bimbini had average fish richness (tied for $12^{\text {th }}$ out of 21 sites in the pre-rainy season and tied for $10^{\text {th }}$ in the rainy season), was above the median for fished species abundance ( $10^{\text {th }}$ in the pre-rainy season and eighth in the rainy season), and below the median for fished species biomass ( $13^{\text {th }}$ in the pre-rainy season and $12^{\text {th }}$ in the rainy season) and fished species biomass per fish $\left(12^{\text {th }}\right.$ in the pre-rainy season and $17^{\text {th }}$ in the rainy season; Table 4.2).

Case Study: Ouani- Some communities obtain management authority and achieve effective and resilient governance through stakeholder determination and occasional use of aggressive force to maintain authority, despite external pressure to abandon management practices. Although Ouani's fishery has weak boundaries and memberships, there is a clear rule: nets are not allowed in reef areas. Ouani fishers decided this rule together and every fisher, whether a member of the association or not, agrees to it and 
finds it within his own self-interest to respect the rule. Monitoring is carried out by fishers themselves and sanctions are utilized as needed. Conflict resolution is carried out formally through the judicial system when a mutual agreement cannot be reached. While the right to organize is not inhibited, there is no active nested support of fisheries governance for Ouani as the municipal and higher levels of government do not impose regulations, legislation, or otherwise intervene in fishers' affairs. However, the conflict resolution arena of the court system is supportive of fishers' arrangements and supported Ouani fishers' arrangements when fishers from a neighboring village challenged them (J. Mouhhidine pers. obs.). Neighboring fishers had depleted their own fishing grounds through extensive net use and began practicing net fishing in Ouani fishing grounds with increasing frequency. Ouani fishers were aware of the threat net use posed to fish stocks and seeing the depleted state of other communities' reefs, they protested the use of nets. Despite a lack of government support in the form of regulation or policing, fishers remained vigilant and aggressive in keeping nets out of their grounds, confiscating and burning them when found in use at Ouani fishing grounds. The courts helped to settle the conflict between the fishing communities and upheld Ouani fishers' rights to determine rules of use for their fishing grounds. Through extensive vigilance and enforcement of steep sanctions, the fishers have succeeded in protecting their fishing grounds from net use.

Ouani fishers find their management institutions are well respected but would like more support, especially from the municipal government that currently maintains a policy of non-involvement. When asked what could be done to improve management of their coral reef, interviewees acknowledged a problem of household trash and the need for 
waste management and proper disposal and a need to prevent sand extraction along the beach adjacent to the reef. While interviewees reported that former coral extraction had degraded the reef, in more recent interviews respondents noted that the reef was beginning to regenerate, as one interviewee described, "they [the corals] are beginning to grow back, we can see it" (translated by J. Mouhhidine). The fishery was perceived as improved in some areas where nets were forbidden, as another interviewee reported, the fish "increase since nets were forbidden. Many fish come at night, even sharks" (translated by J. Mouhhidine). However, some fishers stated they had to go farther out from shore than in the past to find good fishing grounds, because "motorized boats are increasing, lots of fishers and the fuel chases them [the fish] away" (translated by J. Mouhhidine). Interviewees cited only fish habitat as the value of the reef (Table 4.3). When asked about the importance of fishing for livelihood, interviewees were clear that it was "the most important work" (translated by J. Mouhhidine), the occupation that brought home the most income for them.

Even with large seasonal variation in ecological survey results, Ouani's live hard coral cover was highest of all sites studied on Anjouan and among the top 50\% of all sites throughout the Comoros (Table 4.2). Ouani's reef is jeopardized by boat pollution and heavy terrestrial runoff and garbage that discharge from a river mouth onto the reef (personal observations). Ouani has by far the largest number of fishers and boats of all sites. While reef fish species are reported among the top species caught, much effort is also focused on pelagic species. Fish status is mixed, with Ouani above the median for fish richness (second in the pre-rainy season and tied for $10^{\text {th }}$ in the rainy season), below the median for fished species abundance $\left(16^{\text {th }}\right.$ in the pre-rainy season and $14^{\text {th }}$ in the rainy 
season), and below and above the median in different seasons for fished species biomass ( $19^{\text {th }}$ in the pre-rainy season and fourth in the rainy season) and fished species biomass per fish $\left(21^{\text {st }}\right.$ in the pre-rainy season and second in the rainy season; Table 4.2). More thorough benthic and fish transects will be needed to more precisely assess the status of fish and determine whether Ouani's fishery governance is conserving fish.

Case Study: Itsamia- The most effective governance within PMM was at Itsamia, where there was strong participation from the community and high fish richness and fished species abundance, biomass, and biomass per fish, despite poor benthic quality largely due to sedimentation from land-based erosion. Although Itsamia's fishery has weak boundaries and memberships as anyone can come to fish, visitation by outsiders is carefully monitored. The fishery has congruent rules and in addition to the rules established by PMM, requires fishers to adhere to additional gear restrictions. The creation and enduring enforcement of these rules, which are observed only at Itsamia, including by fishers from other communities, makes Itsamia a site with effective and resilient governance. The collective choice arena is a fishers' association with support of the Itsamia village association. Offshore monitoring is carried out by fishers, while the entire community monitors nearshore activities. Sanctions are exercised as seen necessary, either in the village or through the police seated in a nearby village. The support of PMM provides a nested structure to governance. While the park provides support, Itsamia is largely self-reliant in governance, partly due to some past conflicts with park officials and some wavering of park activities and staff presence during the funding lapse. The community of Itsamia has a strong conservation ethic, a strong collective choice arena, and strong governance in many domains, for example, in 
protection of sea turtles that nest on Itsamia's beaches. The community began this conservation effort when concern arose over sea turtle poaching on their beaches and conflicts intensified between poachers and the community. Beginning with education and awareness-raising for the entire community, community members came together to stop poaching and participated in monitoring and sanctions, maintaining their efforts over several years, and successfully ending poaching. They have since worked with foreign scientists on sea turtle conservation. The collective choice arena that guides most community decision-making and governance is a village association with representatives from all other associations in the village (music, sports, etc.). While not everyone in the community directly participates in the association, the variety of members involved in the association and their engagement in discussion of concerns and ideas with non-members in the community ensures that community members are involved in the decision-making process. One association member explained that support of the village association is strong because it "gives so much to others [community members] ... he [a community member] wins because the village is small. If someone gives to the association, everyone will receive" (translated by S. Freed). One of the most recent developments in Itsamia's efforts to protect the turtles is an initiative to clean the beaches and collect trash to prevent household waste from being thrown on the beach, a standard practice in many coastal communities.

Itsamians found that management was well respected and were considering additional management techniques to implement such as no-take reserves. They were aware of material and non-material benefits the reef provides, citing reef values of coastline protection, reef resources, and sea turtle habitat, which is integral to the tourism 
that flourishes in Itsamia. Interviewees reported mixed perceptions of the state of the fishery, some noting an increase in fish stocks and others noting decline (Table 4.3). They perceived reef health as improving, with reports of "good corals near the beach" (translated by H. Youssoufi), although some were aware of the erosion that threatens reef health. Interviewees reported that fishing brought home only enough income for daily household needs such as food and reported agriculture and livestock as additional livelihood activities.

Itsamia's ecological survey results revealed poor benthic status but strong fish status. Itsamia is among the sites lowest in live hard coral cover at $7 \%\left(17^{\text {th }}\right.$ in the prerainy season and $19^{\text {th }}$ in the rainy season). While abundance of fished species was low ( $18^{\text {th }}$ in the pre-rainy season and $19^{\text {th }}$ in the rainy season), fished species biomass, fish taxonomic richness, and biomass per fish for fished species were high (first in the prerainy season and fifth in the rainy season for biomass and first in both seasons for richness and biomass per fish, Table 4.2).

\section{Discussion}

I observed a variety of government and community roles in co-management as well as a meta-community role of Moheli Marine Park. Among the cases observed, effective and resilient governance was achieved only through strong efforts of the community with support of the government. Co-management in both Itsamia and Bimibini could be classified as 'supporting' (Fig.1), as the communities were the strongest actors in co-management, yet received support from other actors. Comanagement at Bimbini experienced antagonistic relations among supposed comanagement actors and therefore is not represented in Figure 1. The meta-community 
role of PMM provided support to communities with strong participation in comanagement and served as a surrogate for community effort at sites with weak community participation. Based on these observations, our recommendations for effective co-management of small scale fisheries in developing countries are to: encourage strong community roles in co-management; develop a meta-community structure to support communities, especially during times and in places of weak participation; and for government to, at the very least, uphold community-based organizations and governance efforts rather than reject them.

The absence of boundaries and memberships was the only feature shared by all of our cases in this study. While boundaries and memberships have often been assumed to be the defining factor of "common property" institutions in contrast to "open access" institutions (Ostrom 1990 citing Ciriacy-Wantrup and Bishop 1975), our study reveals that it is not requisite for CPR governance in all cases. Studies of pastoral systems have also found support for fluid boundaries (Niamir-Fuller 1998; Turner 1999). Even one of the governance systems described in Ostrom's 1990 study, a fishery in Alanya, Turkey, had fluid membership as newcomers were not excluded, and while Ostrom determined this to be a "fragile" governance system, Singleton and Taylor (1992) argued that it was, in fact, a stable system that did not exclude newcomers due to low pressure (no overcrowding) and that such an exclusion could be made as pressure rose. Although our cases lack strict boundaries and memberships, strength of other principles, primarily congruent rules and collective choice arenas differed between sites with effective governance and ineffective governance. Sites with ineffective governance had weak or no rules nor collective choice arenas, sites with effective governance had at least established 
congruent rules, and sites with most effective governance were strong in both congruent rules and collective choice arenas. Monitoring and sanctions are governance principles that follow closely behind rules and collective choice arenas in importance. It became clear from our interviews that strong rules were coupled with monitoring and sanctions, as in the example of Itsamia, and the strength of these latter two principles was greatest when collective choice arenas were also a strong presence.

While inclusion in an MPA did not guarantee community involvement, PMM sites had an advantage of cross-site uniformity in congruent rules, monitoring, and sanctions (at the meta-community level although some communities added their own institutions in addition to those provided by PMM) and I suspect the shared peer pressure and social norms across PMM sites helped to ensure compliance by both local and nonresident resource users. PMM sites also had the advantage of nested governance, although it allowed some sites to rely solely on the park and not participate in governance through community organization. PMM also helped to level the playing field: while rivalries exist among some PMM communities and a hierarchy of community status is present, the meta-community structure ensures all communities play by the same rules. This benefit is described by Singleton and Taylor (1992) who argue that successful CPR governance relies on a "community of mutually vulnerable actors". A cohesive and "mutually vulnerable" community would most likely prevent governance crisis at sites outside PMM, where the greatest barriers to governance success were the lack of adherence to rules and the lack of support from higher authority (Bambao, Bimbini, Fomboni, Nindri). Under governance similar to PMM's, with established rules 
recognized by a larger community of actors and with nested support, governance at these sites would be much more likely to succeed.

External agents such as NGOs, although notably absent from co-management at most sites, must be recognized as key actors in the creation of meta-community structure for PMM communities. The initial role played by the IUCN and other external agents in educating communities and facilitating dialogue allowed the communities to come to a consensus on the need for management and appropriate actions and to continue management at a meta-community level that would not likely have occurred on its own. Other sites that attempted meta-community structures through community and government efforts alone, as in the case of Bimbini, experienced ineffective governance and ultimate failure of the meta-community due to unequal sharing of power and no mutual agreement on governance and management actions. Recognition of each actor's legitimacy, exercise of trust, and negotiation in good faith enable power sharing necessary for co-management to take place (Borrini Feyerabend 2010). The reliance of effective co-management on power sharing amongst stakeholders and between governments and communities has been found in many other cases (Pomeroy et al. 2001; Borrini-Feyerabend 2010), and in the cases of the Comoros can be extended to the role of communities in meta-community structure.

Although a MPA or other meta-community structure may facilitate effective governance, the resilience of CPR governance when faced with challenges appears to be similarly achieved inside and outside of PMM and requires community-level organization and participation. Studies have found, as in the case of Itsamia, that communities successful in CPR governance had evidence of community cohesion in other events and 
practices (Alcorn and Toledo 1998; Cleaver 2000; Zanetell and Knuth 2004). Itsamia was the only PMM community in this study to overcome challenges and develop effective and resilient governance. The community's successful organization to halt turtle poaching, a problem that is an ongoing struggle throughout the rest of PMM, further demonstrates its ability to carry out resilient governance. Apart from Itsamia, the rest of PMM also experiences occasional net use by non-resident fishers. PMM continues to fight poaching and net use and the communities with the lowest incidences of infractions are those with active participation in governance. At the time of this study, the majority of monitoring and sanctions against infractions were carried out by PMM. Unless more sites become actively involved in inhibiting infractions, effective governance within PMM may not continue. Thus, both PMM and non-PMM sites have similar opportunity for resilient governance as community effort is the primary driver.

While I found examples of weak community organization and weak institutions at both PMM and non-PMM sites, among the sites with weak community level institutions, rules remain upheld only at PMM sites. Effective co-management was possible at these PMM sites because the rules were initially agreed upon by the community, enforcement is carried out through nested governance, and the community continues to perceive and obtain the benefit of the rules even with compliance as the only continuing communitylevel engagement in governance. In contrast, each non-PMM case with minimal community-level efforts (i.e., without community level monitoring or sanctions and weak or absent collective choice arenas) experienced ineffective governance.

Governance most strongly correlated with fish richness and biomass per fish. The relationship between governance and other ecological variables was unclear. For 
example, Itsamia, with effective governance, had more fish species than a site with ineffectively governed Domoni (2 times more in the pre-rainy season and 1.1 times more in the rainy season), over 1.5 times (1.6 in the pre-rainy season and 1.7 in the rainy season) the biomass per fish for fished species, but mixed results for the total biomass for fished species, and lower total abundance for fished species (Table 4.2). It is important to note that Domoni has greater live hard coral cover than Itsamia, which could influence the fish variables. Compared to ineffectively governed Nindri, Itsamia had 1.75 times more species, over 3 times ( 3.4 in the pre-rainy season and 15 in the rainy season) biomass per fish for fished species, and over 3 times (3.1 in the pre-rainy season and 11.4 in the rainy season) the total biomass for fished species, but similar total abundance for fished species (Table 4.2). It is important to note that Nindri is likely to experience greater fishing pressure than Itsamia as larger numbers of fishers and fishing boats are present in the community. The consistent results for fish richness and biomass per fish across comparisons indicate that the governance and gear restrictions in place at Itsamia have likely contributed to these results. The relatively low total fished species abundance and biomass at Itsamia, is most likely due to poor habitat conditions that must be considered an influential factor on fish stocks in addition to fishery governance.

Perceptions of management were usually well correlated with governance performance, but perceptions of reef value, reef health, and fishery status were mixed (Table 4.3). Fishing was sufficient as a primary livelihood at three sites but was not sufficient alone at most sites for all levels of governance performance (Table 4.3). The diversity of livelihoods and part-time activity in the fishery reported by fishers is common for many small-scale fisheries in developing countries (Mills et al. 2011). 
Possible reasons for these patterns of fishery participation could be due to many factors. Insufficient income due to small catch is one reason a fisher might engage in other livelihoods and could occur at a site with effective governance, where catch efficiency is limited, or at a site with ineffective governance where overfishing has reduced the stock available for catch. External factors affecting use of the fishery as a livelihood include the market prices for fish and general economy in the country, if catches bring a low market value or if fishing is a generally undervalued livelihood. Many people of the Comoros, fishers and otherwise, take on multiple occupations for income and also rely on subsistence fishing and agriculture, especially in rural communities. Even among nonfishers, fishing is highly regarded as a source of "easy income" due to high demand of the product (pers. obs.).

This study identifies the essential and complementary roles of community and government actors in co-management of small-scale fisheries. Further investigation is necessary to discover how to facilitate the actor roles and relationships that result in effective governance. It would be especially informative to study cases of resilient governance, where a community has strengthened governance institutions and overcome challenges. Findings from further study of resilient governance could provide insight and recommendations for strengthening institutions at sites where effective governance may be vulnerable to changes in leadership, organization, or external pressures. Considering our findings on the importance of fisher organization and nested support as well as social norms, peer pressure, social cohesion, and mutual vulnerability among PMM sites that contributed to effective governance, I recommend focusing further investigations on the relationship of these factors with strength of community roles in co-management. I 
hypothesize several additional factors contribute to strong community and government performance in governance, including: ecological and social understanding of the system, capacities for learning, adaptation, and innovation within the system, and positive external influences on the system.

It is important to remember that the fitness of institutions changes over time, due to changes in social/ecological context and/or the institutions themselves. Our findings support the notions that social-ecological systems undergo frequent, sometimes dramatic, change, and that the best management for these systems builds resilience through flexibility, memory, diversity, and capacity for learning and innovation (Folke et al. 2002). When examining social-ecological systems and their governance, it is important to recognize that "societies are rarely, if ever, in balance with their resources, and commons institutions are rarely stable for long" (Berkes 2006), but with resilient management we have the opportunity to renew institutions and maintain a resilient social-ecological system that will persist through change (e.g. Seixas and Berkes 2003). Further investigations of the development and maintenance of robust governance institutions will elucidate a clear picture of how to achieve resilient governance and a resilient socialecological system. 


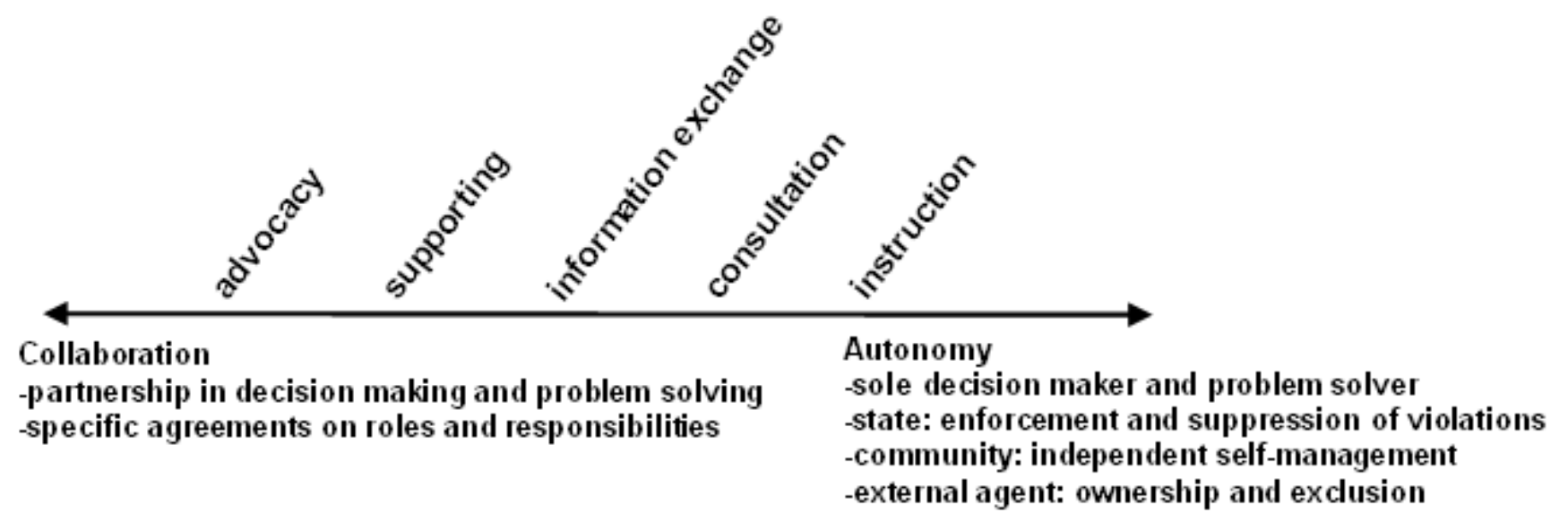

Figure 4.1. Illustration of a spectrum of co-management arrangements. At one end, collaboration occurs in which all actors participate in decision-making and problem solving related to management. Roles and responsibilities of each actor are well defined and agreed upon. At the opposite end, autonomous management occurs (not co-management) in which a single actor controls decision-making and problem solving and assumes all management roles and responsibilities. Each actor may take a different approach to autonomous management, described briefly in the figure. Key words describing other co-management arrangements are placed along the spectrum according to the degree of collaboration and autonomy displayed in each. Adapted from Pomeroy (1995) and Borrini-Feyerabend (2010). 


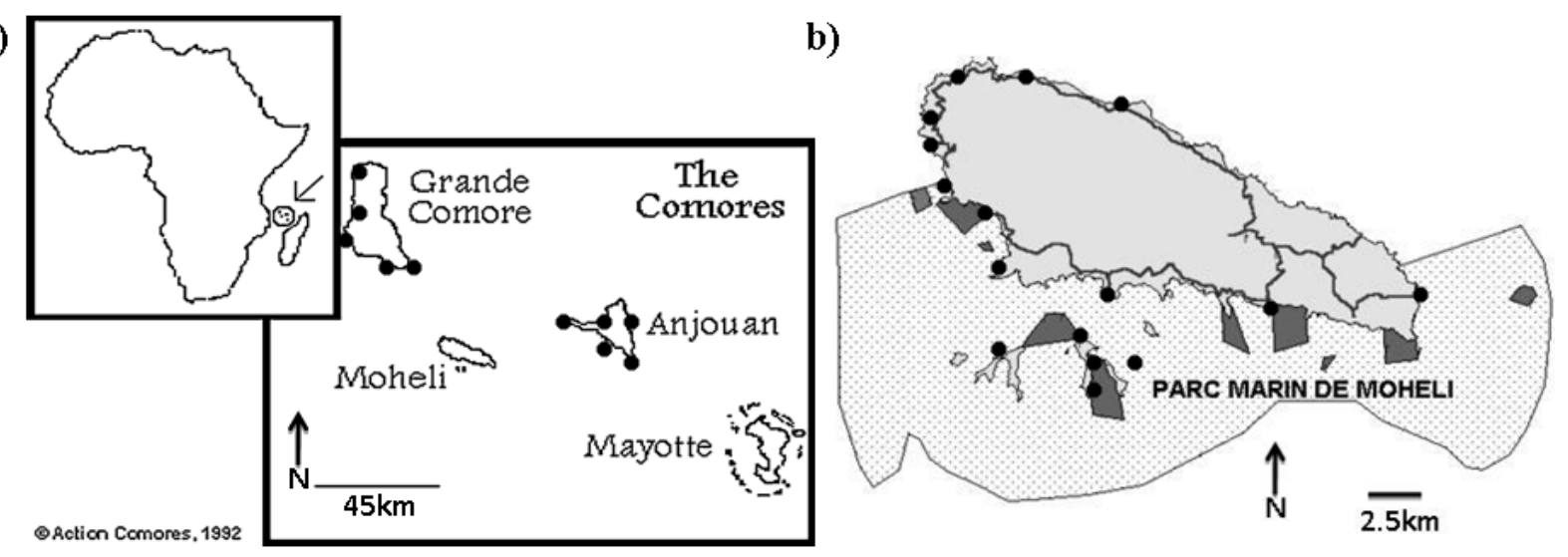

Figure. 4.2. The Comoros. Maps of a) Comoros archipelago (Comoros Union includes Grande Comore, Anjouan, and Mohéli) and b) Mohéli island with Mohéli Marine Park delineated. 
Table 4.1. Governance attributes and institutional performance by site.

\begin{tabular}{|c|c|c|c|c|c|c|c|c|c|c|}
\hline \multirow[b]{2}{*}{ Community } & \multirow{2}{*}{$\begin{array}{l}\text { Within } \\
\text { PMM? }\end{array}$} & \multirow{2}{*}{$\begin{array}{l}\text { Co-management } \\
\text { effectiveness }\end{array}$} & \multicolumn{8}{|c|}{$\begin{array}{l}\text { Ostrom's } 8 \text { Common Pool Resource Governance } \\
\text { Principles }\end{array}$} \\
\hline & & & 1 & 2 & 3 & 4 & 5 & 6 & 7 & 8 \\
\hline Nioumachoi & yes & effective & $\mathrm{W}$ & + & $\mathrm{N}$ & $\bar{M}$ & + & + & + & + \\
\hline Itsamia & Yes & effective\&resilient & $\mathrm{W}$ & + & $\mathrm{RB}$ & + & + & + & + & + \\
\hline Ndrondroni & Yes & effective & $\mathrm{W}$ & + & + & + & + & + & + & + \\
\hline Miringoni & Yes & effective & $\mathrm{W}$ & + & $\mathrm{U}$ & M & + & + & + & + \\
\hline Ouallah1 & Yes & effective & $\mathrm{W}$ & + & $\mathrm{N}$ & M & + & + & + & + \\
\hline Wanani & Yes & effective & $\mathrm{W}$ & + & $\mathrm{N}$ & + & + & + & + & $\mathrm{U}$ \\
\hline Barakani & No & effective & $\mathrm{W}$ & + & W & + & + & + & + & $\mathrm{M}$ \\
\hline Domoni & No & ineffective & $\mathrm{W}$ & $\mathrm{o}$ & o & o & o & $\mathrm{N}$ & + & $\mathrm{o}$ \\
\hline Fomboni & No & ineffective & $\mathrm{W}$ & o & o & o & o & $\mathrm{N}$ & $\mathrm{N}$ & o \\
\hline Hamba & No & effective & W & + & $\mathrm{U}$ & M & + & + & + & $\mathrm{M}$ \\
\hline Hoani & No & effective & $\mathrm{W}$ & + & $\mathrm{W}$ & $\mathrm{U}$ & + & + & + & $\mathrm{M}$ \\
\hline Ouani & No & effective\&resilient & $\mathrm{W}$ & + & + & + & + & + & + & $\mathrm{o}$ \\
\hline Bambao & No & ineffective & W & $\mathrm{o}$ & $\mathrm{O}$ & 0 & $\mathrm{O}$ & $\mathrm{o}$ & + & $\mathrm{o}$ \\
\hline Bimbini & No & ineffective & $\mathrm{W}$ & o & W & + & $\mathrm{I}$ & I & $\mathrm{O}$ & I \\
\hline Nindri & No & ineffective & $\mathrm{W}$ & $\mathrm{U}$ & W & $\mathrm{U}$ & $\mathrm{U}$ & $\mathrm{U}$ & $\mathrm{O}$ & $\mathrm{U}$ \\
\hline Shiroroni & No & effective & $\mathrm{W}$ & + & + & + & $\mathrm{U}$ & + & + & o \\
\hline Chindini & No & effective & $\mathrm{W}$ & + & $\mathrm{U}$ & + & + & + & + & $\mathrm{o}$ \\
\hline Memboi Mboini & No & effective & $\mathrm{W}$ & + & $\mathrm{U}$ & + & + & + & + & $\mathrm{o}$ \\
\hline Itsandra & No & effective & $\mathrm{W}$ & + & + & + & + & + & + & $\mathrm{U}$ \\
\hline Male & No & effective & W & + & o & + & + & + & + & W \\
\hline Moindzaza & No & effective & $\mathrm{U}$ & + & $\mathrm{U}$ & $\mathrm{U}$ & + & + & + & o \\
\hline
\end{tabular}

Note. W: weak; U: unclear; +: fully practiced; o: absent; N: present but not practiced; RB: representative based; M: moderately practiced; I: present but ineffective; Principle 1: boundaries \& memberships; Principle 2: congruent rules; Principle 3: collective choice arenas; Principle 4: monitoring; Principle 5: sanctions; Principle 6: conflict resolution mechanisms; Principle 7: recognized rights to organize; Principle 8: nested units of governance. 
Table 4.2. Coral cover and fish assemblage variables by site.

\begin{tabular}{lllllllll}
\hline & & & & & & & & \\
& & & & & & & & \\
& LHC & LHC & FA & FA & FB & FB & IFB & IFB \\
Community & 2010 & 2011 & 2010 & 2011 & 2010 & 2011 & 2010 & 2011 \\
\hline Nioumachoi & 35 & 26 & 17 & 26 & 9.56 & 4.70 & 0.56 & 0.18 \\
Itsamia & 7 & 7 & 26 & 19 & 18.89 & 39.43 & 0.74 & 2.08 \\
Ndrondroni & 17 & 21 & 51 & 66 & 9.62 & 29.99 & 0.19 & 0.46 \\
Miringoni & 28 & 33 & 30 & 47 & 6.41 & 12.30 & 0.21 & 0.26 \\
Ouallah1 & 28 & 30 & 39 & 80 & 12.25 & 70.90 & 0.32 & 0.89 \\
Wanani & 12 & 18 & 33 & 21 & 7.54 & 6.05 & 0.23 & 0.28 \\
Barakani & 25 & 29 & 47 & 45 & 9.14 & 7.61 & 0.19 & 0.17 \\
Domoni & 24 & 13 & 34 & 83 & 15.85 & 99.78 & 0.47 & 1.20 \\
Fomboni & 14 & 26 & 62 & 22 & 10.38 & 4.12 & 0.17 & 0.19 \\
Hamba & 24 & 29 & 56 & 73 & 17.33 & 51.29 & 0.31 & 0.70 \\
Hoani & 26 & 24 & 5 & 43 & 0.76 & 8.84 & 0.15 & 0.21 \\
Ouani & 21 & 48 & 28 & 34 & 2.79 & 44.98 & 0.10 & 1.31 \\
Bambao & 14 & 27 & 39 & 42 & 5.92 & 7.49 & 0.15 & 0.18 \\
Bimbini & 16 & 24 & 36 & 52 & 6.82 & 8.73 & 0.19 & 0.17 \\
Nindri & 4 & 11 & 27 & 25 & 6.08 & 3.45 & 0.22 & 0.14 \\
Shiroroni & 1 & 1 & 31 & 17 & 11.34 & 2.60 & 0.37 & 0.16 \\
Chindini & 3 & 3 & 4 & 58 & 1.17 & 10.88 & 0.33 & 0.19 \\
Memboi Mboini & 19 & 25 & 43 & 14 & 6.76 & 2.16 & 0.16 & 0.16 \\
Itsandra & 28 & 19 & 40 & 62 & 6.95 & 11.19 & 0.18 & 0.18 \\
Male & 3 & 10 & 34 & 85 & 5.54 & 14.52 & 0.17 & 0.17 \\
Moindzaza & 13 & 31 & 44 & 50 & 7.37 & 8.30 & 0.17 & 0.17 \\
\hline
\end{tabular}

Note. LHC: live hard coral cover (\%); FA: foodfish abundance (number of fish/125m2); FB: foodfish biomass $(\mathrm{kg} / 125 \mathrm{~m} 2)$; IFB: foodfish biomass per individual fish (kg/individual fish) 
Table 4.3. Perceptions by site.

\begin{tabular}{|c|c|c|c|c|c|}
\hline Community & MP & RVP & RHP & FL & FP \\
\hline Nioumachoi & + & $\begin{array}{l}\text { fish habitat } \\
\text { coast protection, fish and turtle }\end{array}$ & + & $\mathrm{M}$ & - \\
\hline Itsamia & + & habitat, sand production & + & M & - \\
\hline Ndrondroni & + & coast protection & $+/-^{b}$ & M & $\mathrm{F}$ \\
\hline Miringoni & + & fish habitat & + & $\mathrm{N}$ & - \\
\hline Ouallah1 & + & $\begin{array}{l}\text { diminishes waves, fish habitat } \\
\text { coast protection, fish habitat, }\end{array}$ & + & M & - \\
\hline Wanani & + & sand production & + & M & - \\
\hline Barakani & $\begin{array}{l}+ \\
\mathrm{o}(2010)^{a}\end{array}$ & fish habitat & + & $\mathrm{P}$ & - \\
\hline Domoni & $+(2009)$ & fish habitat, sand production & + & $\mathrm{P}$ & $\mathrm{F}$ \\
\hline Fomboni & - & fish habitat & - & M & - \\
\hline Hamba & + & makeup & + & $\mathrm{P}$ & $\mathrm{NC}$ \\
\hline Hoani & + & fish habitat & + & M & $\mathrm{NC}$ \\
\hline Ouani & + & fish habitat & - & $\mathrm{P}$ & + \\
\hline Bambao & o & sand production & + & $\mathrm{P}$ & - \\
\hline Bimbini & o & coast protection & - & M & - \\
\hline Nindri & - & aesthetic & - & M & - \\
\hline Shiroroni & + & $\begin{array}{l}\text { none } \\
\text { coast protection, before to }\end{array}$ & $\mathrm{NC}$ & M & + \\
\hline Chindini & + & make lime & + & $\mathrm{P}$ & + \\
\hline Memboi Mboini & - & none & + & M & - \\
\hline Itsandra & + & for divers & - & $\mathrm{P}$ & - \\
\hline Male & $\begin{array}{l}+ \\
\mathrm{NR}\end{array}(2010)^{a}$ & for makeup & + & $\mathrm{P}$ & + \\
\hline Moindzaza & $+(2009)$ & aesthetic & + & $\mathrm{P}$ & - \\
\hline
\end{tabular}

Note. MP: management perception; RVP: reef value perception; RHP: reef health perception; FL: fishing as livelihood; FP: fishery perception; +: positive perception; -: negative perception; o: absence of management; NR: not reported; NC: no change; P: primary livelihood; M: one of many livelihoods; N: not important for livelihood; F: fluctuating change, no clear improvement or decline.

${ }^{a}$ Where differing reports were given in 2009 and 2010 interviews, results from both interviews are reported separately.

${ }^{b}$ Where differing reports were given among interviewees in the same season, both perspectives are reported. 


\section{Literature Cited}

Ahamada, S., L. Bigot, J. Bijoux, J. Maharavo, S. Meunier, M. Moyne-Picard, and N. Paupiah. 2002. Status of the coral reefs of the South West Indian Ocean island node: Comoros, Madagascar, Mauritius, Reunion and Seychelles. In Status of coral reefs of the world: 2002, ed. C. Wilkinson, 378pp. Queensland: Australian Institute of Marine Science.

Alcorn, J.B. and V.M. Toledo. 1998. Resilient resource management in Mexico's forest ecosystems: The contribution of property rights. In Linking Social and Ecological Systems: Management Practices and Social Mechanisms for Building Resilience, eds. Berkes, F. and C. Folke, pp.216-249. New York, NY: Cambridge.

Berkes, F., 2003. Alternatives to conventional management: lessons from small-scale fisheries. Environments 31, 5-19.

Berkes, F. 2006. From community-based resource management to complex systems: The scale issue and marine commons. Ecol. Society 11(1): 45. http://www.ecologyandsociety.org/vol11/iss1/art45/ (accessed 19 December 2012).

Berkes, F., Mahon, R., McConney, P., Pollnac, R.C., Pomeroy, R.S., 2001. Managing Small- Scale Fisheries: Alternative Directions and Methods. International Development Research Centre, Ottawa.

Bigot, L., Maharavo, J., Bijoux, J., Ahamada, S., Meunier, S., Paupiah, N., MoynePicard, M., 2002. Regional report “coral reef monitoring 2002” - South West 
Indian Ocean Region - Present situation and 2000-2002 evolution. Indian Ocean Comission, Quatre Bornes, Mauritius.

Borrini-Feyerabend, G. 2010. Co-management and shared governance - the "effective and equitable" option for natural resources and protected areas? Paper presented at the National Workshop on Co-management Concept and Practice in VietNam, 17-19 March 2010, Soc Trang city, Viet Nam.

CIA World Factbook. 2013 https://www.cia.gov/libarary/publications/the-worldfactbook/geos/cn.html (accessed 14 April 2013).

Cinner, J.E., A. Wamukota, H. Randriamahazo, and A. Rabearisoa. 2009. Toward institutions for community-based management of inshore marine resources in the Western Indian Ocean. Marine Policy 33(3):489-496.

Cleaver, F. 2000. Moral ecological rationality, institutions and the management of common property resources. Development and Change 31: 361-383.

Cox, M., G. Arnold, and S. Villamayor Tomás. 2010. A review of design principles for community-based natural resource management. Ecol. Society 15(4): 38. http://www.ecologyandsociety.org/vol15/iss4/art38/ (accessed 19 December 2012).

Dietz, T., N. Dolsak, E. Ostrom, P.C. Stern. 2002. The drama of the commons. In The Drama of the Commons, eds. E. Ostrom, T. Dietz, N. Dolsak, P.C. Stern, S. Stonich, and E.U. Weber, 3-35. Committee on the Human Dimensions of Global Change. Division of Behavioral and Social Sciences and Education. Washington, DC: National Academy Press. 
Evans, L., N. Cherrett, D. Pemsl. 2011. Assessing the impact of fisheries co-management interventions in developing countries: A meta-analysis. Journal of Environmental Management 92:1938-1949.

FAO 2005. Increasing the contribution of small-scale fisheries to poverty alleviation and food security. FAO Technical Guidelines for Responsible Fisheries 10. Rome: FAO.

Folke, C., S. Carpenter, T. Elmqvist, L. Gunderson, C.S. Holling, and B. Walker. 2002. Resilience and sustainable development: Building adaptive capacity in a world of transformations. Ambio 31(5): 437-440.

Granek, E.F., Brown, M.A., 2005. Co-management approach to marine conservation in Mohéli, Comoros Islands. Conservation Biology 19, 1724-1732.

Hargreaves-Allen, V., Mourato, S., Milner-Gulland, E.J., 2011. A global evaluation of coral reef management performance: are MPAs producing conservation and socio-economic impovements? Environmental Management 47, 684-700.

Mahon, R., 1997. Does fisheries science serve the needs of managers of small stocks in developing countries? Canadian Journal of Fisheries and Aquatic Sciences. 54, 2207- 2213.

Mills, D.J., L. Westlund, G. de Graaf, Y. Kura, R. Willman, K. Kelleher. 2011. Under -reported and undervalued: Small-scale fisheries in the developing world. In Small-scale fisheries management: Frameworks and approaches for the developing world. Eds. Pomeroy, R.S. and N.L. Andrew.CABI Cambridge, MA. $1-15$. 
Niamir-Fuller, M. 1998. The resilience of pastoral herding in Sahelian Africa. In Linking social and ecological systems: management practices and social mechanisms for building resilience, eds. F. Berkes and C. Folke, 250-284. Cambridge, UK: Cambridge University Press.

Ostrom, E. 1990. Governing the Commons. Cambridge, UK: Cambridge University Press.

Patton, M.Q. 2002. Qualitative Research and Evaluation Methods. Thousand Oaks, CA: Sage.

Pauly, D., V. Christensen, S. Guenette, T.J. Pitcher, U. Rashid Sumaila, C.J. Walters, R. Watson, D. Zeller. 2002. Towards sustainability in world fisheries. Nature 418:689-695.

Pomeroy, R.S. 1995. Community-based and co-management institutions for sustainable coastal fisheries management in Southeast Asia. Ocean \& Coastal Management $27: 143-162$.

Pomeroy, R.S., B.M. Katon, I. Harkes. 2001. Conditions affecting the success of fisheries co-management: lessons from Asia. Marine Policy 25:197-208.

Pomeroy, R.S., R. Rivera-Guieb. 2006. Fishery Co- management: A Practical Handbook. CABI Cambridge, MA. 251pp.

Russell, A.J.M. and T. Dobson. 2011. Chiefs as critical partners for decentralized governance of fisheries: An analysis of co-management case studies in Malawi. Society Nat. Resources 24(7): 734-750

Sadovy, Y. 2005. Trouble on the reef: The imperative for managing vulnerable and 
valuable fisheries. Fish and Fisheries 6:167-185.

Schlager, E. 2004. Common-Pool Resource theory. In Environmental Governance Reconsidered: Challenges, Choices, and Opportunities, eds. R.F. Durant, D.J. Fiorino, and R. O'Leary, 145-176. Cambridge, MA: MIT Press.

Seixas, C. S., and F. Berkes. 2003. Dynamics of social-ecological changes in a lagoon fishery in southern Brazil. In Navigating social-ecological systems, eds. F. Berkes, J. Colding, and C. Folke, 271-298. Cambridge, UK: Cambridge University Press.

Sen, S., and J.R. Nielsen. 1996. Fisheries co-management: a comparative analysis. Marine Policy 20:405-418.

Singleton, S. and M.J. Taylor. 1992. Common property, collective action and community. Journal of Theoretical Politics 4(3): 309-324.

Turner, M.D., 1999. Conflict, environmental change, and social institutions in dryland Africa: limitations of the community resource management approach. Society \& Natural Resources 12, 643-657.

Wamukota, A.W., J.E. Cinner, and T.R. McClanahan. 2012. Co-management of coral reef fisheries: A critical evaluation of the literature. Marine Policy 36: 481-488.

Zanetell, B.A. and B.A. Knuth. 2004. Participation rhetoric or community-based management reality? Influences on willingness to participate in a Venezuelan freshwater fishery. World Dev. 32(5):793-807. 
Chapter 5. Conclusion

Although coral reefs are threatened across the globe, management efforts can contribute to maintaining or improving reef health. Most types of management regulations and actor groups involved in management are found to improve reef health. With currently available data, only gear restriction areas and no-take areas are found to be significantly effective in improving a majority of reef health indicators around the world. Management must properly address human impacts in order to be effective. Impacts are locally specific and variable and for our field setting, fishing and land-based impacts were found to predict reef health. Management must function on an appropriate human scale in order to have positive effects on an ecological scale. Co-management can operate through a variety of arrangements and is most effective with community and/or meta-community participation.

From the global meta-analysis I found positive effects across regulation regimes and actors, with enhancement of fish biomass within no-take areas greater than in gear restriction areas. No-take and gear restriction areas performed similarly in improving coral cover and richness and fish abundance and richness. Regional differences in biological outcomes indicated that improvement of highly degraded coral reefs may be negligible regardless of management approach, and that prioritizing minimally degraded reefs for management should be the focus of global conservation efforts. Best practices for management, however, can only be determined with further documentation of partial protection management strategies and research on social outcomes of management across all approaches. 
In the field setting of the Comoros, human impacts were found to relate to reef health, particularly population and fishing predicted fish richness, abundance, and biomass with seasonal variation in the effects. Site orientation strongly predicted benthic cover. Recommended management approaches to address these impacts include an adaptive management approach to examine the effectiveness of implementing fishery closure areas, beach protection from sand extraction, and zoning for coastal development. For coral reefs of the Comoros and other nations, baseline data on reef health and localized anthropogenic impacts, monitoring over time, and controlled experiments can provide evidence of human impacts on reefs and facilitate an adaptive management approach for protecting fragile reef ecosystems. As an original study design incorporating suites of natural and anthropogenic factors, the study revealed the importance of considering the relationship between local human activities and reef health.

Across several field cases of co-management in the Comoros, we found that management can be effective and can prevail over socioeconomic challenges, especially with strong community leadership, cohesion, and lateral and nested support. Community and meta-community participation and support of these actors by state actors and external agents were found to be essential for effective governance. Community participation can be initiated through education and capacity building and presence of a meta-community structure, as observed with Mohéli Marine Park, can prevent ineffective governance when community participation is low. Further investigation is necessary to identify processes and conditions that contribute to the development of strong governance institutions, with social capital and adaptability of particular interest. 
I sought to expand the narrow focus of human impacts and solutions, mainly fisheries and no-take areas, to encompass more thorough investigation of impacts, including land based impacts of coastal development and sand extraction, and of possible solutions, including gear restrictions and co-management. I believe this research succeeded in these goals and makes a substantial contribution to the knowledge and practice of coral reef management. The unified study of social and natural factors influencing reef health carried out in this dissertation is essential to improving management. The synthesis of management cases from around the world and comparison of management performance in biological and available social outcomes conducted in the Comoros also greatly furthers the conversation on best management practices. The identification of effective roles in co-management provides insight into practices that practitioners can adopt to improve management.

It is my hope that future studies will continue to explore broader sources of impacts and additional management approaches in order to address context and localized management efforts as key factors in management effectiveness and outcomes. As key areas upon which to focus research, I recommend that future studies investigate management areas that utilize gear restrictions and other partial protection measures for fishing or address land-based impacts on coral reefs, especially erosion and sedimentation. I also recommend implementing long-term monitoring as the most compelling means to assess management effects on coral reef health. Finally, I recommend further investigation into social outcomes of various management strategies and in-depth study of factors contributing to resilient co-management efforts. 
Areas only briefly touched upon in this dissertation that require further investigation include: equity among resource users; the values and decision-making processes that guide management; and incorporating resilience into management processes and structures. This dissertation is one step along the way to developing coral reef management plans and actions that build capacity for social-ecological resilience, transformation, and adaptation at a local and regional scale, for application globally. 


\section{References}

Ahamada, S., L. Bigot, J. Bijoux, J. Maharavo, S. Meunier, M. Moyne-Picard, and N. Paupiah. 2002. Status of the coral reefs of the South West Indian Ocean island node: Comoros, Madagascar, Mauritius, Reunion and Seychelles. In Status of coral reefs of the world: 2002, ed. C. Wilkinson, 378pp. Queensland: Australian Institute of Marine Science.

Alcorn, J.B. and V.M. Toledo. 1998. Resilient resource management in Mexico's forest ecosystems: The contribution of property rights. In Linking Social and Ecological Systems: Management Practices and Social Mechanisms for Building Resilience, eds. Berkes, F. and C. Folke, pp.216-249. New York, NY: Cambridge.

Alder, J. 1996. Have tropical marine protected areas worked? An initial analysis of their success. Coastal Management 24: 97-114.

Amesbury, S.S. 1981. Effects of turbidity on shallow-water reef fish assemblages in Truk, Eastern Caroline Islands. Proceedings of the Fourth International Coral Reef Symposium, Manila, 1:155-159.

Andrews, J.C. and P. Gentien. 1982. Upwelling as a source of nutrients for the Great Barrier Reef ecosystems: A solution to Darwin's question? Marine Ecology Progress Series 8: 257-269.

Bellwood, D.R., T.P. Hughes, C. Folke, and M. Nystrom. 2004. Confronting the coral reef crisis. Nature 429: 827-833. 
Berkes, F., 2003. Alternatives to conventional management: lessons from small-scale fisheries. Environments 31, 5-19.

Berkes, F. 2006. From community-based resource management to complex systems: The scale issue and marine commons. Ecol. Society 11(1): 45. http://www.ecologyandsociety.org/vol11/iss1/art45/ (accessed 19 December 2012).

Berkes, F. and C. Folke. 1998. Linking social and ecological systems for resilience and sustainability. In Linking Social and Ecological Systems: Management Practices andSocial Mechanisms for Building Resilience, eds. Berkes, F. and C. Folke, 125. Cambridge, New York.

Berkes, F., R. Mahon, P. McConney, R. Pollnac, R. Pomeroy. 2001. Managing SmallScale Fisheries Alternative Directions and Methods. Ottawa: International Development Research Centre, 309pp.

Bigot, L., Maharavo, J., Bijoux, J., Ahamada, S., Meunier, S., Paupiah, N., MoynePicard, M., 2002. Regional report “coral reef monitoring 2002" - South West Indian Ocean Region - Present situation and 2000-2002 evolution. Indian Ocean Comission, Quatre Bornes, Mauritius.

Borenstein, M., L.V. Hedges, J.P.T. Higgins, H.R. Rothstein. 2009. Introduction to MetaAnalysis. West Sussex, UK: Wiley.

Borrini-Feyerabend, G. 2010. Co-management and shared governance - the "effective and equitable" option for natural resources and protected areas? Paper presented 
at the National Workshop on Co-management Concept and Practice in VietNam, 17-19 March 2010, Soc Trang city, Viet Nam.

Burgin, S. and N. Hardiman. 2011. The direct physical, chemical and biotic impacts on Australian coastal waters due to recreational boating. Biodiversity Conservation 20:683-701.

Burke, L., K. Reytar, M. Spalding, and A. Perry. 2011. Reefs at Risk Revisited. World Resources Institute, Washington, DC. 111p.

Choat, J.H., A.M. Ayling, and D.R. Schiel. 1988. Temporal and spatial variation in an island fish fauna. Journal of Experimental Marine Biology and Ecology. 121:91111.

Christie, P. 2004. Marine Protected Areas as biological successes and social failures in Southeast Asia. American Fisheries Society Symposium 42: 155-164.

CIA World Factbook. 2013 https://www.cia.gov/libarary/publications/the-worldfactbook/geos/cn.html (accessed 14 April 2013).

Cinner, J. E. and S. Aswani 2007. Integrating customary management into marine conservation. Biological Conservation 140: 201-216.

Cinner, J.E. and T.R. McClanahan. 2006. Socioeconomic factors that lead to overfishing in small-scale coral reef fisheries of Papua New Guinea. Environmental Conservation 33:73-80.

Cinner, J.E., T.R. McClanahan, T.M. Daw, N.A.J. Graham, J. Maina, S.K. Wilson, and T.P. Hughes. 2009. Linking Social and Ecological Systems to Sustain Coral Reef 
Fisheries. Current Biology 19:206-212.

Cinner, J.E., T.R. McClanahan, M.A. MacNeil, N.A.J. Graham, T.M. Daw, A. Mukminin, D.A. Feary, A.L. Rabearisoa, A. Wamukota, N. Jiddawi, S.J. Campbell, A.H. Baird, F.A. Januchowski-Hartley, S. Hamed, R. Lahari, T. Morove, J. Kuange. 2012. Comanagement of coral reef social-ecological systems. Proceedings of the National Academy of Sciences 109:5219-5222.

Cinner, J.E., Sutton, S.G., Bond, T.G. 2007. Socioeconomic thresholds that affect use of customary fisheries management tools. Conservation Biology 21: 1603-1611.

Cinner, J.E., A. Wamukota, H. Randriamahazo, and A. Rabearisoa. 2009. Toward institutions for community-based management of inshore marine resources in the Western Indian Ocean. Marine Policy 33(3):489-496.

Cleaver, F. 2000. Moral ecological rationality, institutions and the management of common property resources. Development and Change 31: 361-383.

Conand C., Chabanet P., Quod J.P., Bigot L. 1998. Manuel méthodologique pour le suivi del'état de santé des récifs coralliens du sud-ouest de l'Océan Indien. Mauritius : Commission Océan Indien. (In French).

Connell, J. H., T. P. Hughes, and C.C. Wallace. 1997. A 30-years study of coral abundance, recruitment, and disturbance at several scales in space and time. Ecological Monographs 67:461-488.

Cote, I.M., I. Mosquiera, J.D. Reynolds. 2001. Effects of marine reserve characteristics on the protection of fish populations: a meta-analysis. Journal of Fish Biology 
59:178-189.

Cote, I.M., J.A. Gill, T.A. Gardner, A.R. Watkinson. 2005. Measuring coral reef decline through meta-analyses. Philosophical Transactions of the Royal Society B 360:385-305.

Coordination des Comores. 1996. Bilan socio-économique et écologique de la zone côtière des Comores Enseignements et orientation pour les étapes suivantes. Mauritius : Commission Océan Indien. (In French).

Cox, M., G. Arnold, and S. Villamayor Tomás. 2010. A review of design principles for community-based natural resource management. Ecol. Society 15(4): 38. http://www.ecologyandsociety.org/vol15/iss4/art38/ (accessed 19 December 2012).

Crabbe, J.M. and D.J. Smith 2005. Sediment impacts on growth rates of Acropora and Porites corals from fringing reefs of Sulawesi, Indonesia. Coral Reefs 24:437-441.

Daw, T.M., J.E. Cinner, T.R. McClanahan, N.A.J. Graham, S.K. Wilson. 2011. Design factors and socioeconomic variables associated with ecological responses to fishery closures in the Western Indian Ocean. Coastal Management 39:412-424.

Dietz, T., N. Dolsak, E. Ostrom, P.C. Stern. 2002. The drama of the commons. In The Drama of the Commons, eds. E. Ostrom, T. Dietz, N. Dolsak, P.C. Stern, S. Stonich, and E.U. Weber, 3-35. Committee on the Human Dimensions of Global Change. Division of Behavioral and Social Sciences and Education. Washington, DC: National Academy Press.

Done, T.J. 1982. Patterns in the distribution of coral communities across the central Great 
Barrier Reef. Coral Reefs 1:95-107.

Dorenbosch, M., M.G.G. Grol, M.J.A. Christianen, I. Nagelkerken, G. van der Velde. 2005. Indo-Pacific seagrass beds and mangroves contribute to fish density and diversity on adjacent coral reefs. Marine Ecology Progress Series 302:63-76.

Dorenbosch, M., W.C.E.P. Verberk, I. Nagelkerken, G. van der Velde. 2007. Influence of habitat configuration on connectivity between fish assemblages of Caribbean seagrass beds, mangroves and coral reefs. Marine Ecology Progress Series 334:103-116.

Dulvy, N.K., D.S. Stanwell-Smith, W.R.T. Darwall, C.J. Horrill. 1994. Coral mining at Mafia Island, Tanzania: A management dilemma. Ambio 24:358-365.

Emerick, C.M. and R.A. Duncan. 1982. Age progressive volcanism in the Comores Archipelago, western Indian Ocean and implications for Somali plate tectonics. Earth and Planetary Science Letters 60:415-428.

Evans, L., N. Cherrett, D. Pemsl. 2011. Assessing the impact of fisheries co-management interventions in developing countries: A meta-analysis. Journal of Environmental Management 92:1938-1949.

Fabricius, K.E. and G. De'ath. 2004. Identifying ecological change and its causes: a case study on coral reefs. Ecological Applications 14:1448-1465.

FAO 2005. Increasing the contribution of small-scale fisheries to poverty alleviation and food security. FAO Technical Guidelines for Responsible Fisheries 10. Rome: FAO.

Fisher, R., B.T. Radford, N. Knowlton, R.E. Brainard, F.B. Michaelis, M.J. Caley 2011. 
Global mismatch between research effort and conservation needs of tropical coral reefs. Conservation Letters 4:64-72.

Folke, C., S. Carpenter, T. Elmqvist, L. Gunderson, C.S. Holling, and B. Walker. 2002. Resilience and sustainable development: Building adaptive capacity in a world of transformations. Ambio 31(5): 437-440.

Fox, H.E. and R.L. Caldwell. 2006. Recovery from blast fishing on coral reefs: a tale of two scales. Ecological Applications 16:1631-1635.

Garcia Charton, J.A., I.D. Williams, A. Perez Ruzafa, M. Milazzo, R. Chemello, C. Marcos, M.-S. Kitsos, A. Koukouras, S. Riggio. Evaluating the ecological effects of Mediterranean marine protected areas: habitat, scale and the natural variability of ecosystems. Environmental Conservation 27:159-178.

Gardner, T.A., I.M. Cote, J.A. Gill, A. Grant, and A.R. Watkinson. 2003.Long-term region-wide declines in Caribbean corals. Science, 301:958-960.

Garpe, K.C., S.A.S. Yahya, U. Lindahl, M.C. Ohman. 2006. Long-term effects of the 1998 coral bleaching event on reef fish assemblages. Marine Ecology Progress Series 315:237-247.

Graham N.A.J., T.R. McClanahan, M.A. MacNeil, S.K. Wilson, N.V.C. Polunin, S. Jennings, P. Chabanet, S. Clark, M.D. Spalding, Y. Letourneur, L. Bigot, R. Galzin, M.C. Ohman, K.C. Garpe, A.J. Edwards, C.R.C. Sheppard. 2008. Climate warming, Marine Protected Areas and the ocean-scale integrity of coral reef ecosystems. PLoS ONE 3(8): e3039. doi:10.1371/journal.pone.0003039.

Granek, E.F., Brown, M.A., 2005. Co-management approach to marine conservation in 
Mohéli, Comoros Islands. Conservation Biology 19, 1724-1732.

Gutierrez, N.L., R. Hilborn, O. Defeo. 2011. Leadership, social capital and incentives promote successful fisheries. Nature 470:386-389.

Guzman, H.M., C. Guevara, A. Castillo. 2003. Natural disturbances and mining of Panamanian coral reefs by indigenous people. Conservation Biology 17:13961401.

Halpern, B.S. 2003. The Impact of Marine Reserves: Do Reserves Work and Does Reserve Size Matter? Ecological Applications 13:S117-S137.

Halpern, B.S., S.E. Lester, J.B. Kellner. 2010. Spillover from marine reserves and the replenishment of fished stocks. Environmental Conservation 36: 268-276.

Halpern, B.S., S. Walbridge, K.A. Selkoe, C.V. Kappel, F. Micheli, C. D’Agrosa, J.F. Bruno, K.S. Casey, C. Ebert, H.E. Fox, R. Fujita, D. Heinemann, H.S. Lenihan, E.M.P. Madin, M.T. Perry, E.R. Selig, M. Spalding, R. Steneck, R. Watson 2008. A global map of human impact on marine ecosystems. Science 319:948-952.

Halpern, B.S., C.V. Kappel, K.A. Selkoe, F. Micheli, C.M. Ebert, C. Kontgis, C.M. Krain, R.G. Martone, C. Shearer, S.J. Teck 2009. Mapping cumulative human impacts to California Current marine ecosystems. Conservation Letters 2:138148.

Hargreaves-Allen, V., Mourato, S., Milner-Gulland, E.J., 2011. A global evaluation of coral reef management performance: are MPAs producing conservation and socio-economic impovements? Environmental Management 47, 684-700.

Hawkins, J.P. and C.M. Roberts. 1994. The growth of coastal tourism in the Red Sea: 
Present and future effects on coral reefs. Ambio 23:503-508.

Hedges, L.V., J. Gurevitch, P.S. Curtis. 1999. The meta-analysis of response ratios in experimental ecology. Ecology 80:1150-1156.

Hoegh-Guldberg, O., P.J. Mumby, A.J. Hooten, R.S. Steneck, P. Greenfield, E. Gomez, C.D. Harvell, P.F. Sale, A.J. Edwards, K. Caldeira, N. Knowlton, C.M. Eakin, R. Iglesias-Prieto, N. Muthiga, R.H. Bradbury, A. Dubi, M.E. Hatziolos. 2007. Coral reefs under rapid climate change and ocean acidification. Science 318:1737-1742.

Holling, C.S., and G.K. Meffe. 1996. Command and control and the pathology of natural resource management. Conservation Biology 10:328-337.

Huber, R.M. and R. Meganck 1990. The management challenge of Grand Anse beach erosion, Grenada, West Indies. Ocean \& Shoreline Management 13:99-109.

Hughes, T. P. 1994. Catastrophes, phase-shifts, and large-scale degradation of a Caribbean coral reef. Science 265:1547-1551.

Hughes, T.P., A.H. Baird, D.R. Bellwood, M. Card, S.R. Connolly, C. Folke, R. Grosberg, O. Hoegh-Guldberg, J.B.C. Jackson, J. Kleypas, J.M. Lough, P. Marshall, M. Nystrom, S.R. Palumbi, J.M. Pandolfi, B. Rosen, and J. Roughgarden. 2003. Climate change, human impacts, and the resilience of coral reefs. Science 301:929-933.

Hughes, T. P., M. J. Rodrigues, D. R. Bellwood, D. Ceccarelli, O. Hoegh-Guldberg, L. McCook, N. Moltschaniwskyj, M. S. Pratchett, R. S. Steneck, and B. Willis. 2007. Phase Shifts, Herbivory, and the Resilience of Coral Reefs to Climate Change. Current Biology 17: 360-365. 
Hughes, T.P. and Tanner, J.E. 2000. Recruitment failure, life histories, and long-term decline of Caribbean corals. Ecology 81: 2250-2263.

Hughes, T.P., N.A.J. Graham, J.B.C. Jackson, P.J. Mumby, R.S. Steneck. 2010. Rising to the challenge of sustaining coral reef resilience. Trends in Ecology and Evolution $25: 633-642$.

Jeninngs, S. and N.V.C. Polunin. 1996. Effects of fishing effort and catch rate upon the structure and biomass of Fijian reef fish communities. Journal of Applied Ecology $33: 400-412$.

Jolliffe, I.T. 1986. Principal Component Analysis. New York: Springer-Verlag. 246p.

Kaufman, L., S. Sandin, E. Sala, D. Obura, F. Rohwer, T Tschirky. 2011. Coral Health Index (CHI): measuring coral community health. Science and Knowledge Division, Conservation International, Arlington, VA, USA. 15pp.

Kaunda-Arara, B., J.M. Mwaluma, G.A. Locham, V. Oresland, M.K. Osore. 2009. Temporal variability in fish larval supply to Malindi Marine Park, coastal Kenya. Aquatic Conservation: Marine and Freshwater Ecosystems 19:S10-S18.

Klein C.J., N.C. Ban, B.S. Halpern, M.Beger, E.T. Game, H.S. Grantham, A. Green, T.J. Klein, S. Kininmonth, E. Treml, K. Wilson, H.P. Possingham. 2010. Prioritizing land and sea conservation investments to protect coral reefs. PLoS ONE 5(8): e12431. doi:10.1371/journal.pone.0012431.

Kleypas, J.A. 1996. Coral reef development under naturally turbid conditions: fringing reefs near Broad Sound, Australia. Coral Reefs 15:153-167.

Lester, S.E., and B.S. Halpern. 2008. Biological responses in marine no-take reserves 
versus partially protected areas. Marine Ecology Progress Series 367:49-56.

Lester, S.E., B.S. Halpern, K. Grorud-Colvert, J. Lubchenco, B.I. Ruttenberg, S.D. Gaines, S.Airame, and R.R. Warner. 2009. Biological effects within no-take marine reserves: a global synthesis. Marine Ecology Progress Series 384:33-46.

Letourneur, Y. 1996. Dynamics of fish communities on Reunion fringing reefs, Indian Ocean. II Patterns of temporal fluctuations. Journal of Experimental Marine Biology and Ecology 195:31-52.

Liu, J., T. Dietz, S.R. Carpenter, C. Folke, M. Alberti, C.L. Redman, S.H. Schneider, E. Ostrom, A.N. Pell, J. Lubchenco, W.W. Taylor, Z. Ouyang, P. Deadman, T. Kratz, and W. Provencher. 2007. Coupled human and natural systems. Ambio 36: 639-649.

Luckhurst, B.E. and K. Luckhurst. 1978. Analysis of the influence of substrate variables on coral reef fish communities. Marine Biology 49:317-323.

Mahon, R., 1997. Does fisheries science serve the needs of managers of small stocks in developing countries? Canadian Journal of Fisheries and Aquatic Sciences. 54, 2207- 2213.

Mascia, M. B. 2003. The human dimension of coral reef marine protected areas: recent social science research and its policy implications. Conservation Biology 17: 630632.

Mascia, M.B., C.A. Claus, R. Naidoo. 2010. Impacts of Marine Protected Areas on fishing communities. Conservation Biology 24:1424-1429. 
Mascia, M.B. and S. Pailler. 2011. Protected area downgrading, downsizing, and degazettement (PADDD) and its conservation implications. Conservation Letters $4: 9-20$.

McClanahan, T.R. 1994. Kenyan coral reef lagoon fish: Effects of fishing, substrate complexity, and sea urchins. Coral Reefs 13:231-241.

McClanahan, T. R. 1999. Is there a future for coral reef parks in poor tropical countries? Coral Reefs 18: 321-325.

McClanahan, T.R. 2011. Human and coral reef use interactions: from impacts to solutions? Journal of Experimental Marine Biology and Ecology 408:3-10.

McClanahan, T.R. 2008. Response of the coral reef benthos and herbivory to fishery closure management and the 1998 ENSO disturbance. Oecologia 155:169-177.

McClanahan, T.R. (editor) 2008. Manual and Field Guide for Monitoring Coral Reef Ecosystems, Fisheries, and Stakeholders. Wildlife Conservation Society, New York.

McClanahan, T.R., C.C. Hicks, and E.S. Darling. 2008. Malthusian overfishing and efforts to overcome it on Kenyan coral reefs. Ecological Applications 18:15161529.

McClanahan, T.R., M. Nugues, and S. Mwachireya. 1994. Fish and sea urchin herbivory and competition in Kenyan coral reef lagoons: the role of reef management. Journal of Experimental Marine Biology and Ecology 184:237-254.

McClanahan, T.R., Mwaguni, S. and N.A. Muthiga. 2005. Management of the Kenyan coast. Ocean \& Coastal Management 48:901-931. 
McClanahan, T.R., J. Maina, J. Davies. 2005. Perceptions of resource users and managers towards fisheries management options in Kenyan coral reefs. Fisheries Management and Ecology 12:105-112.

McClanahan, T.R., C.A. Abunge, J.E. Cinner. 2012. Heterogeneity in fishers' and managers' preferences towards management restrictions and benefits in Kenya. Environmental Conservation 39:357-369.

McGehee, M.A. 1994. Correspondence between assemblages of coral reef fishes and gradients of water motion, depth, and substrate size off Puerto Rico. Marine Ecology Progress Series 105:243-255.

Mengersen, K., C.H. Schmid, M.D. Jennions, J. Gurevitch. 2013. Statistical models and approaches to inference. In Handbook of Meta-analysis in Ecology and Evolution, J. Koricheva, J. Gurevitch, and K. Mengersen, eds. Princeton, NJ: Princeton University Press; pp 89-107.

Michener, W.K. 2008. Quantitatively evaluating restoration experiments: research design, statistical analysis, and data management considerations. Restoration Ecology 5:324-337.

Millenium Ecosystem Assessment. Hassan R., Scholes, R. and Ash, N. (eds.). Island Press, Washington, D.C.

Miller, M.W. and M.E. Hay. 1996. Coral-seaweed-grazer-nutrient interactions on temperate reefs. Ecological Monographs 66:323-344.

Mills, D.J., L. Westlund, G. de Graaf, Y. Kura, R. Willman, K. Kelleher. 2011. Under -reported and undervalued: Small-scale fisheries in the developing world. In 
Small-scale fisheries management: Frameworks and approaches for the developing world. Eds. Pomeroy, R.S. and N.L. Andrew.CABI Cambridge, MA. $1-15$.

Moberg, F. and C. Folke. 1999. Ecological goods and services of coral reef ecosystems. Ecological Economics 29:215-233.

Mumby, P.J., A.J. Edwards, J.E. Arias-Gonzalez, K.C. Lindeman, P.G. Blackwell, A. Gall, M.I. Gorczynska, A.R. Harborne, C.L. Pescod, H. Renken, C.C.C. Wabnitz, G. Llewellyn. 2004. Mangroves enhance the biomass of coral reef fish communities in the Caribbean. Nature 427:533-536.

Mumby, P.J., C.P. Dahlgren, A.R. Harborne, C.V. Kappel, F. Micheli, D.R. Brumbaugh, K.E. Holmes, J.M. Mendes, K. Broad, J.N. Sanchirico, K. Buch, S. Box, R.W. Stoffle, A.B. Gill. 2006. Fishing, trophic cascades, and the process of grazing on coral reefs. Science 311:98-101.

Mumby, P.J., A.R. Harborne, J. Williams, C.V. Kappel, D.R. Brumbaugh, F. Micheli, K.E. Holmes, C.P. Dahlgren, C.B. Paris, and P.G. Blackwell. 2007. Trophic cascade facilitates coral recruitment in a marine reserve. Proceedings of the National Academy of sciences of the United States of America 104:8362-8367.

Mumby P.J. and A.R. Harborne 2010. Marine Reserves Enhance the Recovery of Corals on Caribbean Reefs. PLoS ONE 5(1): e8657. doi:10.1371/journal.pone.0008657

Mumby, P.J., A. Hastings, H.J. Edwards. 2007. Thresholds and the resilience of Caribbean coral reefs. Nature 450:98-101.

Munday P.L. 2004. Habitat loss, resource specialization, and extinction on coral reefs. 
Global Change Biology 10:1642-1647.

Nagelkerken, I., C.M. Roberts, G. van der Velde, M. Dorenbosch, M.C. van Riel, E. Cocheret de la Moriniere, P.H. Nienhuis. 2002. How important are mangroves and seagrass beds for coral-reef fish? The nursery hypothesis tested on an island scale. Marine Ecology Progress Series 244:299-305.

Newton, K., I.M. Cote, G.M. Pilling, S. Jennings, N.K. Dulvy. 2007. Current and future sustainability of island coral reef fisheries. Current Biology 17:655-658.

Nguyen, L.V. 2012. Temporal dynamics of coral reef fish communities in Nha Trang Bay marine protected area, South-Central Vietnam. Environmental Biology of Fishes 93:277-293.

Niamir-Fuller, M. 1998. The resilience of pastoral herding in Sahelian Africa. In Linking social and ecological systems: management practices and social mechanisms for building resilience, eds. F. Berkes and C. Folke, 250-284. Cambridge, UK: Cambridge University Press.

Nystrom, M., C. Folke, and F. Moberg 2000. Coral reef disturbance and resilience in a human-dominated environment. Trends in Ecology \& Evolution 15:413-417.

Ohman, M.C., A. Rajasurya, O. Linden 1994. Human Disturbances on Coral Reefs in Sri Lanka: A Case Study. Ambio 22:474-480.

Olds, A.D., R.M. Connolly, K.A. Pitt, P.S. Maxwell. 2012. Primacy of seascape connectivity effects in structuring coral reef assemblages. Marine Ecology Progress Series 462:191-203. 
Ostrom, E. 1990. Governing the Commons. Cambridge, UK: Cambridge University Press.

Pandolfi, J.M., R.H. Bradbury, E. Sala, T.P. Hughes, K.A. Bjorndal, R.G. Cooke, D. McArdle, L. McClenachan, M.J.H. Newman, G. Paredes, R.R. Warner, and J.B.C. Jackson. 2003. Global trajectories of the long-term decline of coral reef ecosystems. Science 301:955 -958.

Pastorok, R. A., and G. R. Bilyard. 1985. Effects of Sewage Pollution on Coral Reef Communities. Marine Ecology Progress Series 21: 175-189.

Patton, M.Q. 2002. Qualitative Research and Evaluation Methods. Thousand Oaks, CA: Sage.

Pauly, D., V. Christensen, S. Guenette, T.J. Pitcher, U. Rashid Sumaila, C.J. Walters, R. Watson, D. Zeller. 2002. Towards sustainability in world fisheries. Nature 418:689-695.

Pinca, S., M. Kronen, F. Magron, B. McArdle, L. Vigliola, M. Kulbicki, S. Andrefouet. 2012. Relative importance of habitat and fishing in influencing reef fish communities across seventeen Pacific Island Countries and Territories. Fish and Fisheries 13:361-379.

Pomeroy, R.S. 1995. Community-based and co-management institutions for sustainable coastal fisheries management in Southeast Asia. Ocean \& Coastal Management $27: 143-162$.

Pomeroy, R.S., B.M. Katon, I. Harkes. 2001. Conditions affecting the success of fisheries co-management: lessons from Asia. Marine Policy 25:197-208. 
Pomeroy, R.S., R. Rivera-Guieb. 2006. Fishery Co- management: A Practical Handbook. CABI Cambridge, MA. 251pp.

Reopanichkul, P., T. A. Schlacher, R. W. Carter, and S. Worachananant. 2009. Sewage Impacts Coral Reefs at Multiple Levels of Ecological Organization. Marine Pollution Bulletin 58: 1356-1362.

Roberts, C.M. 1995. Effects of fishing on the ecosystem structure of coral reefs. Conservation Biology 9:988-995.

Rogers, C.S. The effect of shading on coral reef structure and function. Journal of Experimental Marine Biology and Ecology 41:269-288.

Rogers, C.S. 1990. Responses of coral reefs and reef organisms to sedimentation. Marine Ecology Progress Series 62:185-202.

Rosenberg, M.S., D.C. Adams, J. Gurevitch. 2000. METAWIN Version 2: Statistical Software for Meta-Analysis. Boston, MA: Sinauer Associates.

Ruckleshaus, M., T. Klinger, N. Knowlton, and D.P. DeMaster 2008. Marine ecosystembased management in practice: Scientific and governance challenges. BioScience $58: 53-63$

Russ, G.R. 2002. Yet another reiew of marine reserves as reef fisheries management tools. In Coral Reef Fishes Dynamics and Diversity in a Complex Ecosystem, P.F. Sale, ed. Academic Press pp. 421-443.

Russ, G.R. and A.C. Alcala. 1989. Effects of intense fishing pressure on an assemblage of coral reef fishes. Marine Ecology Progress Series 56:13-27.

Russ,G.R. and A.C. Alcala. 2011. Enhanced biodiversity beyond marine reserve 
boundaries: The cup spillith over. Ecological Applications 21:241-250.

Russell, A.J.M. and T. Dobson. 2011. Chiefs as critical partners for decentralized governance of fisheries: An analysis of co-management case studies in Malawi. Society Nat. Resources 24(7): 734-750

Sadovy, Y. 2005. Trouble on the reef: The imperative for managing vulnerable and valuable fisheries. Fish and Fisheries 6:167-185.

Sala, E., E. Ballesteros, P. Dendrinos, A. Di Franco, F. Ferretti, D. Foley, S. Fraschetti, A. Friedlander, J. Garrabou, H. Guclusoy, P. Guidetti, B.S. Halpern, B. Hereu, A.A. Karamanlidis, Z. Kizilkaya, E. Macpherson, L. Mangialajo, S. Mariani, F. Micheli, A. Pais, K. Riser, A.A. Rosenberg, M. Sales, K.A. Selkoe, R. Starr, F. Tomas, M. Zabala. 2012. The structure of Mediterranean rocky reef ecosystems across environmental and human gradients, and conservation implications. PLoS ONE 7(2): e32742. doi:10.1371/journal.pone.0032742

Sale, P. 1977. Maintenance of high diversity in coral-reef fish communities. The American Naturalist 111:337-359.

Sale, P.F., R.K. Cowen, B.S. Danilowicz, G.P. Jones, J.P. Kritzer, K.C. Lindeman, S. Planes, N.V.C. Polunin, G.R. Russ, Y.J. Sadovy, R.S. Steneck. 2005. Critical science gaps impede use of no-take fishery reserves. Trends in Ecology \& Evolution 20:74-80.

Schlager, E. 2004. Common-Pool Resource theory. In Environmental Governance Reconsidered: Challenges, Choices, and Opportunities, eds. R.F. Durant, D.J. Fiorino, and R. O'Leary, 145-176. Cambridge, MA: MIT Press. 
Seixas, C. S., and F. Berkes. 2003. Dynamics of social-ecological changes in a lagoon fishery in southern Brazil. In Navigating social-ecological systems, eds. F. Berkes, J. Colding, and C. Folke, 271-298. Cambridge, UK: Cambridge University Press.

Selig, E.R. and J.F. Bruno. 2010. A global analysis of the effectiveness of marine protected areas in preventing coral loss. PLoS ONE 5:e9278.

Sen, S., and J.R. Nielsen. 1996. Fisheries co-management: a comparative analysis. Marine Policy 20:405-418.

Singleton, S. and M.J. Taylor. 1992. Common property, collective action and community. Journal of Theoretical Politics 4(3): 309-324.

Stallings, C.D. 2009. Fishery-independent data reveal negative effect of human population density on Caribbean predatory fish communities. PLOS ONE 4(5): e5333. doi:10.1371/journal.pone.0005333.

Steneck, R.S. 1988. Herbivore on coral reefs: a synthesis. Proceedings of the $6^{\text {th }}$ International Coral Reef Symposium. Australia pp.37-49.

Stockwell, B., C.R.L. Jadloc, R.A. Abesamis, A.C. Alcala, G.R. Russ. 2009. Trophic and benthic responses to no-take marine reserve protection in the Philippines. Marine Ecology Progress Series 389:1-15.

Turner, M.D., 1999. Conflict, environmental change, and social institutions in dryland Africa: limitations of the community resource management approach. Society \& Natural Resources 12, 643-657. 
Underwood, A.J. 1994. On beyond BACI: sampling designs that might reliably detect environmental disturbances. Ecological Applications 4:3-15.

Wamukota, A.W., J.E. Cinner, and T.R. McClanahan. 2012. Co-management of coral reef fisheries: A critical evaluation of the literature. Marine Policy 36: 481-488.

West, J.M. and R.V. Salm. 2003. Resistance and resilience to coral bleaching: Implications for coral reef conservation and management. Conservation Biology 17:956-967.

Wilkinson, C. Status of coral reefs of the world: 2004. Townsville: Australian Instistue of Marine Science 301p.

Williams, I.D. and Polunin, N.V.C. 2001. Large-scale associations between macroalgal cover and grazer biomass on mid-depth reefs in the Caribbean. Coral Reefs 19: $358-366$.

Williams, I.D., W.J. Walsh, R.E. Schroeder, A.M. Friedlander, B.L. Richards, K.A. Stamoulis. 2008. Assessing the importance of fishing impacts on Hawaiian coral reef fish assemblages along regional-scale human population gradients. Environmental Conservation 35:261-272.

Wolanski, E., J.A. Martinez, R.H. Richmond 2009. Quantifying the impact of watershed urbanization on a coral reef: Maunalua Bay, Hawaii. Estuarine, Coastal and Shelf Science 84:259-268.

Zanetell, B.A. and B.A. Knuth. 2004. Participation rhetoric or community-based management reality? Influences on willingness to participate in a Venezuelan freshwater fishery. World Dev. 32(5):793-807. 
Zuur, A.F., E.N. Ieno, and G.M. Smith 2007. Analysing Ecological Data. Springer, New York: 648pp. 
Appendix A. Meta-analysis data \& forest plots

Table A.1. Natural log of response ratio by case for coral cover.

\begin{tabular}{|c|c|c|c|c|c|c|c|c|c|c|}
\hline 1st author/year & Case & Technique & $\begin{array}{l}\text { Actor } \\
\text { group }\end{array}$ & Region & $\begin{array}{l}\text { Study } \\
\text { type }\end{array}$ & $\begin{array}{l}\text { Number } \\
\text { of spp. }\end{array}$ & $\begin{array}{l}\text { Mgmt } \\
\text { area } \\
\left(\mathrm{km}^{\wedge} 2\right)\end{array}$ & $\begin{array}{l}\text { Years } \\
\text { mana } \\
\text { ged }\end{array}$ & $\ln R$ & $\mathrm{v}(\ln R)$ \\
\hline campbell12 & Anoi Itam & $G$ & C & IP & $\mathrm{S}$ & 45 & 1.21 & & 1.03 & 0.12 \\
\hline wam01 & Apo & $G$ & $\mathrm{CO}$ & IP & $\mathrm{T}$ & & & 7 & -0.02 & 0.24 \\
\hline campbell12 & le Meulee & $G$ & $\mathrm{C}$ & IP & $\mathrm{S}$ & 45 & 1.78 & & 1.12 & 0.12 \\
\hline campbell12 & Kawasan Wisata & $\mathrm{G}$ & $\mathrm{CO}$ & IP & $\mathrm{S}$ & 45 & 2.07 & 8 & 0.83 & 0.24 \\
\hline kamukuru04 & mafia & $\mathrm{G}$ & S & WIO & $\mathrm{S}$ & & 822.00 & 5 & 0.54 & 0.03 \\
\hline Coles & Manele-Hulopoe & G & $\mathrm{S}$ & IP & $\mathrm{S}$ & & 1.12 & 31 & 2.23 & 0.17 \\
\hline Tyler11 & Menai & $G$ & $\mathrm{CO}$ & WIO & $\mathrm{S}$ & & 470.00 & 5 & -0.32 & 0.09 \\
\hline Coles & Molokini & $\mathrm{G}$ & $\mathrm{S}$ & IP & $\mathrm{S}$ & & 0.36 & 30 & 2.26 & 0.12 \\
\hline McCetal97 & Mvuleni Galu & G & C & WIO & $\mathrm{S}$ & & & 20 & 0.03 & 0.41 \\
\hline campbell12 & Panglima Laut & $\mathrm{G}$ & $\mathrm{C}$ & IP & $\mathrm{S}$ & 45 & 2.06 & 8 & 0.29 & 0.14 \\
\hline friedlander10 & Pupukea & G & $S$ & IP & $S$ & 5 & 0.71 & 4 & 0.28 & 0.10 \\
\hline Cros\&McC03 & Ras Iwatine & G & $\mathrm{S}$ & WIO & & & & 2 & -0.93 & 0.05 \\
\hline Mcc06 & Tanga & $G$ & C & WIO & $\mathrm{S}$ & 27 & 5.75 & 9 & 0.34 & 0.04 \\
\hline monaco09 & VICR & $\mathrm{G}$ & $\mathrm{S}$ & $\mathrm{CA}$ & $\mathrm{S}$ & & & 7 & -0.89 & 0.02 \\
\hline stockwell09 & andulay & NTA & C & IP & $S$ & & 0.06 & 4 & 0.38 & 0.01 \\
\hline wam01 & Apo & NTA & $\mathrm{CO}$ & IP & $\mathrm{T}$ & & 0.76 & 15 & 0.01 & 0.06 \\
\hline stockwell09 & ave maria & NTA & C & IP & $\mathrm{S}$ & & 0.10 & 9 & -0.07 & 0.01 \\
\hline wam01 & Balicasag & NTA & $\mathrm{CO}$ & IP & $\mathrm{BACl}$ & & 0.22 & 13 & -0.19 & 0.03 \\
\hline stockwell09 & baobaon & NTA & C & IP & $S$ & & 0.30 & 3 & 0.03 & 0.01 \\
\hline
\end{tabular}




\begin{tabular}{|c|c|c|c|c|c|c|c|c|c|c|}
\hline raymundo08 & Basdiot & NTA & & IP & $S$ & & & 5 & -0.02 & 0.01 \\
\hline stockwell09 & baylimango & NTA & $\mathrm{C}$ & IP & $\mathrm{S}$ & & 0.10 & 3 & 1.80 & 0.07 \\
\hline raymundo08 & Bil-isan & NTA & & IP & $S$ & & & 5 & -0.09 & 0.00 \\
\hline stockwell09 & bio-os & NTA & $\mathrm{C}$ & IP & $S$ & & 0.09 & 3 & 0.20 & 0.03 \\
\hline miller09 & BIRNM & NTA & $S$ & $\mathrm{CA}$ & $S$ & & 77.00 & 6 & 0.75 & 0.04 \\
\hline stockwell09 & bongalonan & NTA & $\mathrm{C}$ & IP & $\mathrm{S}$ & & 0.20 & 11 & 0.10 & 0.01 \\
\hline stockwell09 & canlucani & NTA & $\mathrm{C}$ & IP & $\mathrm{S}$ & & 0.09 & 6 & -0.33 & 0.02 \\
\hline stockwell09 & carang & NTA & $\mathrm{C}$ & IP & $S$ & & 0.12 & 5 & -0.54 & 0.02 \\
\hline White10 & Colase & NTA & $\mathrm{CO}$ & IP & $S$ & & 0.16 & 6 & 0.36 & 0.06 \\
\hline White10 & $\begin{array}{l}\text { Daanlungsod- } \\
\text { Guiwang }\end{array}$ & NTA & $\mathrm{CO}$ & IP & S & & 0.23 & 8 & 1.79 & 0.23 \\
\hline epstein & Eilat & NTA & $S$ & WIO & $S$ & 1 & & 8 & 1.14 & 0.01 \\
\hline kramer07 & floridakeys & NTA & $\mathrm{S}$ & $\mathrm{CA}$ & S & & 1.16 & 7 & -0.83 & 0.03 \\
\hline White10 & Gawi & NTA & $\mathrm{CO}$ & IP & $S$ & & 0.13 & 7 & 0.18 & 0.06 \\
\hline evans04 & GBR & NTA & $S$ & IP & $S$ & & 16008.00 & 14 & 0.09 & 0.01 \\
\hline raymundo08 & Gilutungan & NTA & & IP & $\mathrm{S}$ & & & 5 & 0.11 & 0.04 \\
\hline White10 & Granada(Boljoon) & NTA & $\mathrm{CO}$ & IP & S & & 0.09 & 9 & -0.02 & 0.03 \\
\hline stockwell09 & guimputlan & NTA & C & IP & S & & 0.13 & 7 & -0.07 & 0.01 \\
\hline friedlander10 & Hanauma & NTA & $\mathrm{S}$ & IP & $\mathrm{S}$ & 5 & 0.41 & 40 & 1.34 & 1.05 \\
\hline tkachenko10 & hobihu(nanwan) & NTA & $\mathrm{CO}$ & IP & $\mathrm{S}$ & 8 & 1.50 & 2 & -0.08 & 0.02 \\
\hline brownsaracino07 & hol chan & NTA & $S$ & IP & $S$ & & 4.01 & 16 & 0.16 & 0.01 \\
\hline friedlander10 & Honolua & NTA & $\mathrm{S}$ & IP & $\mathrm{S}$ & 5 & 0.19 & 29 & 0.44 & 0.59 \\
\hline Mcc06 & Kisite & NTA & $\mathrm{S}$ & WIO & $\mathrm{S}$ & 32 & 10.00 & 31 & 0.51 & 0.05 \\
\hline
\end{tabular}




\begin{tabular}{|c|c|c|c|c|c|c|c|c|c|c|}
\hline stockwell09 & lutoban & NTA & C & IP & $S$ & & 0.12 & 1 & 1.04 & 0.09 \\
\hline raymundo08 & Maayong & NTA & & IP & $\mathrm{S}$ & & & 5 & 0.07 & 0.15 \\
\hline Dumas10 & Mangorongo & NTA & $\mathrm{CO}$ & IP & S & & 0.01 & 3 & -0.14 & 0.02 \\
\hline Dumas10 & Marow & NTA & $\mathrm{CO}$ & IP & $\mathrm{S}$ & & 0.02 & 4 & -0.28 & 0.03 \\
\hline stockwell09 & masaplod norte & NTA & C & IP & $\mathrm{S}$ & & 0.06 & 10 & 0.16 & 0.05 \\
\hline stockwell09 & masaplod sur & NTA & C & IP & $\mathrm{S}$ & & 0.06 & 8 & 0.37 & 0.04 \\
\hline poonian08 & misali (pemba) & NTA & $\mathrm{CO}$ & WIO & $\mathrm{S}$ & & 1.40 & 4 & 0.19 & 0.01 \\
\hline Cros\&McC03 & MombasaMNP & NTA & $\mathrm{S}$ & WIO & $\mathrm{S}$ & & & 12 & 0.53 & 0.03 \\
\hline aswani07 & Nusa Hope & NTA & C & IP & S & & 0.83 & 4 & 0.08 & 0.07 \\
\hline wam01 & Pamilican & NTA & $\mathrm{C}$ & IP & & & 1.35 & 14 & -0.11 & 1.24 \\
\hline stockwell09 & poblacion I & NTA & C & IP & $\mathrm{S}$ & & 0.09 & 6 & 1.08 & 0.03 \\
\hline raymundo08 & Saavedra & NTA & & IP & $\mathrm{S}$ & & & 5 & 0.05 & 0.01 \\
\hline wam01 & Sumilon & NTA & $\mathrm{CO}$ & IP & & & 0.23 & 4 & -0.09 & 0.62 \\
\hline white84 & Sumilon & NTA & $\mathrm{CO}$ & IP & RT & 32 & & 8 & 0.40 & 0.22 \\
\hline raymundo08 & Talima & NTA & & IP & $S$ & & & 5 & 0.00 & 0.11 \\
\hline stockwell09 & tandayag & NTA & C & IP & $\mathrm{S}$ & & 0.06 & 5 & 0.24 & 0.03 \\
\hline raymundo08 & Tawala & NTA & & IP & $S$ & & & 5 & 0.12 & 0.02 \\
\hline white91 & Tubbataha & NTA & $\mathrm{CO}$ & IP & $\mathrm{T}$ & & & 11 & 0.08 & 0.02 \\
\hline miller09 & VINP & NTA & $S$ & $\mathrm{CA}$ & $S$ & & 22.86 & 45 & 0.55 & 0.02 \\
\hline Kuo12 & Wanlitung & NTA & $S$ & IP & $\mathrm{T}$ & & 237.70 & 20 & -0.99 & 0.03 \\
\hline raymundo08 & Zaragosa & NTA & & IP & $S$ & & & 5 & -0.03 & 0.00 \\
\hline cinner06 & Kakarotan & $\mathrm{P}$ & $\mathrm{C}$ & IP & $\mathrm{S}$ & 51 & 0.50 & 0 & 0.26 & 0.28 \\
\hline
\end{tabular}




IP

\begin{tabular}{|l|l|}
\hline S & 51 \\
\hline &
\end{tabular}

0.58 0.10 
Table A.2. Natural log of response ratio by case for fish abundance.

\begin{tabular}{|c|c|c|c|c|c|c|c|c|c|c|}
\hline 1st author/year & Case & Technique & $\begin{array}{l}\text { Actor } \\
\text { group }\end{array}$ & Region & $\begin{array}{l}\text { Study } \\
\text { type }\end{array}$ & $\begin{array}{l}\text { Number } \\
\text { of } \\
\text { species }\end{array}$ & $\begin{array}{l}\text { Mgmt } \\
\text { area } \\
\left(\mathrm{km}^{\wedge} 2\right)\end{array}$ & $\begin{array}{l}\text { Years } \\
\text { managed }\end{array}$ & $\ln R$ & $\mathrm{v}(\ln R)$ \\
\hline williams09 & West hawaii & & $\mathrm{S}$ & IP & $\mathrm{BACl}$ & 1 & & 8 & 0.24 & 0.00 \\
\hline russ89 & Sumilon & NTA & $\mathrm{CO}$ & IP & $\mathrm{BACl}$ & 102 & & 9 & 0.48 & 0.06 \\
\hline Ardiwijaya06 & Anoi Itam & GR & C & IP & $S$ & 333 & 1.21 & & -1.16 & 42.22 \\
\hline abesamis05 & Apo & GR & $\mathrm{CO}$ & IP & $\mathrm{T}$ & 1 & & 18 & 1.33 & 0.04 \\
\hline amargos 10 & Cuba & GR & $S$ & $\mathrm{CA}$ & $S$ & 7 & 950.00 & 9 & -0.03 & 0.00 \\
\hline karnauskas & Glovers & GR & $S$ & $\mathrm{CA}$ & $\mathrm{T}$ & 40 & 277.20 & 10 & -0.15 & 0.01 \\
\hline Ardiwijaya06 & le Meulee & GR & C & IP & $\mathrm{S}$ & 333 & 1.78 & & 2.05 & 0.46 \\
\hline Campbell07 & $\begin{array}{l}\text { Kawasan } \\
\text { Wisata }\end{array}$ & GR & $\mathrm{S}$ & IP & $\mathrm{S}$ & & 2.07 & 9 & 1.37 & 0.15 \\
\hline friedlander10 & Kealakekua & GR & $\mathrm{S}$ & IP & $\mathrm{S}$ & 5 & 1.24 & 39 & 0.45 & 0.08 \\
\hline Ardiwijaya06 & Panglima Laut & GR & $\mathrm{C}$ & IP & S & 333 & 2.06 & 8 & 0.21 & 0.27 \\
\hline friedlander10 & Pupukea & GR & $\mathrm{S}$ & IP & $S$ & 5 & 0.71 & 5 & 0.55 & 0.01 \\
\hline monaco09 & VICR & GR & $S$ & $\mathrm{CA}$ & $S$ & 25 & & 7 & -0.01 & 0.00 \\
\hline Coles & $\begin{array}{l}\text { Manele- } \\
\text { Hulopoe }\end{array}$ & GR & $S$ & IP & $\mathrm{S}$ & 14 & 1.12 & 31 & 0.05 & 0.03 \\
\hline Coles & Molokini & GR & $\mathrm{S}$ & IP & $\mathrm{S}$ & 10 & 0.36 & 30 & -0.01 & 0.04 \\
\hline Tyler11 & Menai & GR & $\mathrm{CO}$ & WIO & $S$ & 92 & 470.00 & 5 & 0.17 & 0.03 \\
\hline nardi04 & Abrolhos & NTA & $\mathrm{S}$ & IP & $\mathrm{BACl}$ & 1 & & 8 & 0.51 & 0.16 \\
\hline preuss09 & Abore & NTA & $\mathrm{S}$ & IP & $\mathrm{T}$ & 213 & 100.00 & 6 & -0.18 & 0.01 \\
\hline White10 & Arbor(Boljoon) & NTA & $\mathrm{CO}$ & IP & $\mathrm{S}$ & 45 & 0.09 & 9 & 0.58 & 0.14 \\
\hline wam01 & Balicasag & NTA & $\mathrm{CO}$ & IP & $\mathrm{BACl}$ & 126 & 0.22 & 13 & 0.41 & 0.02 \\
\hline chapman99 & Barbados & NTA & $\mathrm{S}$ & $\mathrm{CA}$ & $\mathrm{S}$ & 38 & 1.38 & 25 & -0.62 & 0.00 \\
\hline pittman08 & BIRNM & NTA & $\mathrm{S}$ & CA & $S$ & & 77.00 & 5 & 0.03 & 0.01 \\
\hline
\end{tabular}

茯 


\begin{tabular}{|c|c|c|c|c|c|c|c|c|c|c|}
\hline White10 & Colase & NTA & $\mathrm{CO}$ & IP & $S$ & & & 6 & 1.63 & 0.36 \\
\hline White10 & $\begin{array}{l}\text { Daanlungsod- } \\
\text { Guiwang } \\
\end{array}$ & NTA & $\mathrm{CO}$ & IP & $S$ & 45 & 0.23 & 8 & 1.86 & 5.05 \\
\hline Hamilton 11 & Dyual (site1) & NTA & $\mathrm{CO}$ & IP & S & 1 & 0.01 & 5 & 1.02 & 0.29 \\
\hline kellner & exuma & NTA & $S$ & $\mathrm{CA}$ & $S$ & 3 & 442.00 & 21 & 0.52 & 0.07 \\
\hline kramer07 & floridakeys & NTA & S & $\mathrm{CA}$ & S & 1 & 1.16 & 7 & 0.13 & 0.04 \\
\hline White10 & Gawi & NTA & $\mathrm{CO}$ & $\mathrm{IP}$ & $S$ & & 0.13 & 7 & 0.68 & 0.20 \\
\hline russ08 & GBR & NTA & $S$ & $\mathrm{IP}$ & $\mathrm{BACl}$ & 2 & & 2 & -0.61 & 0.03 \\
\hline karnauskas & Glovers & NTA & $\mathrm{S}$ & $\mathrm{CA}$ & $\mathrm{T}$ & 40 & 72.80 & 10 & -0.40 & 0.02 \\
\hline friedlander10 & Hanauma & NTA & $S$ & IP & $S$ & & 0.41 & 41 & 0.33 & 0.06 \\
\hline tkachenko10 & hobihu(nanwan) & NTA & $\mathrm{CO}$ & IP & S & 68 & 1.50 & 2 & 0.61 & 0.02 \\
\hline brownsaracino07 & hol chan & NTA & $S$ & CA & $S$ & 9 & 4.01 & 16 & 0.89 & 0.02 \\
\hline svensson09 & hon ong WIB & NTA & $\mathrm{P}$ & IP & S & 242 & 0.11 & 6 & 1.29 & 0.03 \\
\hline svensson09 & hon ong WIBP & NTA & $\mathrm{P}$ & IP & $S$ & 242 & 0.05 & 1.5 & 0.94 & 0.06 \\
\hline friedlander10 & Honolua & NTA & $\mathrm{S}$ & $\mathrm{IP}$ & $S$ & & 0.19 & 29 & 1.09 & 0.01 \\
\hline aswani10 & Kida & NTA & $\mathrm{C}$ & $\mathrm{IP}$ & $S$ & 6 & 0.05 & & 0.71 & 0.01 \\
\hline chateau05 & laregnere & NTA & $\mathrm{S}$ & IP & $S$ & 110 & 6.49 & 14 & 0.01 & 0.02 \\
\hline letourneur96 & longogori & NTA & $S$ & $\mathrm{WIO}$ & $S$ & 239 & 4.50 & 3 & -0.19 & 0.05 \\
\hline hernandezdelgado07 & $\begin{array}{l}\text { Luis Pena } \\
\text { Channel }\end{array}$ & NTA & $\mathrm{S}$ & CA & $\mathrm{BACl}$ & 30 & 4.80 & 5 & 1.35 & 0.07 \\
\hline goetze11 & namena & NTA & $\mathrm{C}$ & IP & $S$ & 341 & 60.60 & 12 & 0.14 & 0.08 \\
\hline goetze11 & namuri & NTA & $\mathrm{C}$ & IP & $S$ & 341 & 4.25 & 4 & -0.01 & 0.05 \\
\hline aswani 10 & Nusa Hope & NTA & $\mathrm{C}$ & IP & S & 6 & 0.83 & 3 & 0.68 & 0.05 \\
\hline
\end{tabular}




\begin{tabular}{|c|c|c|c|c|c|c|c|c|c|c|}
\hline christie03 & San Salvador & NTA & $\mathrm{CO}$ & IP & $\mathrm{T}$ & & 1.25 & 9 & 0.88 & 0.00 \\
\hline wantiez96 & $\begin{array}{l}\text { SW New } \\
\text { Caledonia } \\
\text { (Noumea) }\end{array}$ & NTA & $\mathrm{S}$ & IP & $\mathrm{BACl}$ & 205 & 27.00 & 4 & 0.94 & 0.08 \\
\hline Hamilton 11 & Tigak (site 10) & NTA & $\mathrm{CO}$ & IP & S & 1 & 0.01 & 5 & 0.62 & 0.56 \\
\hline wam01 & Apo & NTA & $\mathrm{CO}$ & IP & $T$ & 126 & 0.76 & 7 & 1.02 & 0.04 \\
\hline Galal02 & Nabq & NTA & $\mathrm{CO}$ & WIO & $\mathrm{T}$ & 14 & & 5 & 0.24 & 0.01 \\
\hline wam01 & Pamilican & NTA & C & IP & $\mathrm{BACl}$ & 126 & 1.35 & 14 & 0.02 & 0.05 \\
\hline wam01 & Sumilon & NTA & $\mathrm{CO}$ & IP & RT & 126 & 0.23 & 4 & -0.55 & 0.00 \\
\hline cinner06 & Kakarotan & $\mathrm{P}$ & C & IP & S & 87 & 0.50 & & -0.03 & 0.03 \\
\hline cinner06 & Muluk & $\mathrm{P}$ & $\mathrm{C}$ & IP & $S$ & 87 & 0.58 & 60 & 0.02 & 0.04 \\
\hline Bartlett09 & $\begin{array}{l}\text { harvested North } \\
\text { Efate }\end{array}$ & $\mathrm{P}$ & $\mathrm{CO}$ & IP & $S$ & 6 & 0.42 & 4 & 0.25 & 0.01 \\
\hline Bartlett09 & $\begin{array}{l}\text { permanent } \\
\text { North Efate }\end{array}$ & NTA & $\mathrm{CO}$ & IP & $S$ & 6 & 0.38 & 4 & 0.11 & 0.01 \\
\hline White10 & Pasil & NTA & & $\mathrm{IP}$ & $S$ & & & & 1.15 & 0.23 \\
\hline
\end{tabular}


Table A.3. Natural log of response ratio by case for fish biomass.

\begin{tabular}{|c|c|c|c|c|c|c|c|c|c|c|}
\hline $\begin{array}{l}\text { 1st } \\
\text { author/year }\end{array}$ & Case & $\begin{array}{l}\text { Techni } \\
\text { que }\end{array}$ & $\begin{array}{l}\text { Actor } \\
\text { group }\end{array}$ & $\begin{array}{l}\text { Regi } \\
\text { on }\end{array}$ & $\begin{array}{l}\text { Study } \\
\text { type }\end{array}$ & $\begin{array}{l}\text { Numbe } \\
\text { r of } \\
\text { species }\end{array}$ & $\begin{array}{l}\text { Mgmt } \\
\text { area } \\
\left(\mathrm{km}^{\wedge} 2\right)\end{array}$ & $\begin{array}{l}\text { Years } \\
\text { manag } \\
\text { ed }\end{array}$ & $\ln R$ & $\mathrm{v}(\ln R)$ \\
\hline cinner05 & Ahus & $G$ & $\mathrm{C}$ & $\mathrm{IP}$ & $\mathrm{S}$ & & & 60 & 0.48 & 0.02 \\
\hline campbell12 & Anoiltam & $G$ & C & $\mathrm{IP}$ & $\mathrm{S}$ & 333 & 1.21 & & 0.16 & 0.00 \\
\hline alcala05 & Apo & $G$ & $\mathrm{CO}$ & $\mathrm{IP}$ & $\mathrm{T}$ & 47 & & 16 & 0.30 & 0.22 \\
\hline newman06 & Glovers & $G$ & $S$ & $\mathrm{CA}$ & $\mathrm{T}$ & & 277.20 & 6 & -0.65 & 0.07 \\
\hline campbell12 & leMeulee & $G$ & $\mathrm{C}$ & IP & $S$ & 333 & 1.78 & & 0.17 & 0.01 \\
\hline campbell12 & $\begin{array}{l}\text { Kawasan } \\
\text { Wisata }\end{array}$ & $\mathrm{G}$ & $\mathrm{CO}$ & IP & $S$ & 333 & 2.07 & 8 & 0.14 & 0.00 \\
\hline friedlander06 & $\begin{array}{l}\text { Kealakek } \\
\text { ua }\end{array}$ & G & S & IP & $\mathrm{s}$ & 10 & 1.23 & 35 & 2.05 & 0.02 \\
\hline friedlander06 & Lapakahi & $G$ & $S$ & $\mathrm{IP}$ & $S$ & 10 & 0.54 & 25 & 0.45 & 0.03 \\
\hline friedlander06 & $\begin{array}{l}\text { Manele- } \\
\text { Hulopoe }\end{array}$ & $\mathrm{G}$ & $S$ & IP & $S$ & 10 & 1.12 & 27 & 0.22 & 0.03 \\
\hline Tyler11 & Menai & $G$ & $\mathrm{CO}$ & WIO & $S$ & 92 & 470.00 & 5 & 0.33 & 0.05 \\
\hline friedlander06 & Molokini & $G$ & $S$ & $\mathrm{IP}$ & $S$ & 10 & 0.36 & 27 & 0.14 & 0.03 \\
\hline McCetal97 & $\begin{array}{l}\text { MvuleniG } \\
\text { alu }\end{array}$ & G & C & WIO & $\mathrm{s}$ & 28 & & 20 & 0.11 & 0.12 \\
\hline friedlander06 & OldKona & G & $S$ & IP & $S$ & 10 & 1.06 & 11 & 0.47 & 0.03 \\
\hline campbell12 & $\begin{array}{l}\text { Panglima } \\
\text { Laut }\end{array}$ & G & C & IP & $\mathrm{S}$ & 333 & 2.06 & 8 & -0.08 & 0.00 \\
\hline friedlander06 & Pupukea & $G$ & $S$ & $\mathrm{IP}$ & $\mathrm{S}$ & 10 & 0.72 & 20 & 1.43 & 0.06 \\
\hline jennings95 & SteAnne & $G$ & $S$ & $\mathrm{WIO}$ & $S$ & 134 & 2.10 & 21 & 0.81 & 0.12 \\
\hline Mcc06 & Tanga & $G$ & C & $\mathrm{WIO}$ & $S$ & 41 & 5.75 & 9 & 1.72 & 0.01 \\
\hline monaco09 & VICR & $G$ & $S$ & $\mathrm{CA}$ & $\mathrm{S}$ & 25 & 50.00 & 7 & 0.03 & 0.00 \\
\hline friedlander06 & Waialea & $G$ & $S$ & $\mathrm{IP}$ & $S$ & 10 & 0.14 & 19 & 0.45 & 0.06 \\
\hline preuss09 & Abore & NTA & $S$ & $\mathrm{IP}$ & $\mathrm{T}$ & 213 & 100.00 & 6 & -0.36 & 0.04 \\
\hline stockwell09 & andulay & NTA & C & $\mathrm{IP}$ & $S$ & & 0.06 & 4 & 0.96 & 0.15 \\
\hline
\end{tabular}




\begin{tabular}{|c|c|c|c|c|c|c|c|c|c|c|}
\hline alcala05 & Apo & NTA & $\mathrm{CO}$ & IP & $\mathrm{T}$ & 47 & & 16 & 0.56 & 0.05 \\
\hline stockwell09 & avemaria & NTA & $\mathrm{C}$ & IP & $\mathrm{S}$ & & 0.10 & 9 & 3.07 & 0.22 \\
\hline stockwell09 & baobaon & NTA & $\mathrm{C}$ & IP & $S$ & & 0.30 & 3 & 0.47 & 0.18 \\
\hline stockwell09 & $\begin{array}{l}\text { bayliman } \\
\text { go }\end{array}$ & NTA & $\mathrm{C}$ & IP & $\mathrm{S}$ & & 0.10 & 3 & 0.63 & 0.07 \\
\hline stockwell09 & bio-os & NTA & $\mathrm{C}$ & IP & $S$ & & 0.09 & 3 & -0.38 & 0.06 \\
\hline pittman08 & BIRNM & NTA & $S$ & CA & $S$ & & 77.00 & 5 & 0.33 & 0.03 \\
\hline stockwell09 & $\begin{array}{l}\text { bongalon } \\
\text { an }\end{array}$ & NTA & C & IP & $\mathrm{S}$ & & 0.20 & 11 & 2.28 & 0.35 \\
\hline stockwell09 & canlucani & NTA & $\mathrm{C}$ & IP & $S$ & & 0.09 & 6 & 2.50 & 0.36 \\
\hline stockwell09 & carang & NTA & $\mathrm{C}$ & IP & $S$ & & 0.12 & 5 & 1.42 & 0.23 \\
\hline jennings95 & Cousin & NTA & $P$ & WIO & $S$ & 134 & 0.40 & 26 & 0.90 & 0.11 \\
\hline harborne09 & exuma & NTA & $S$ & $\mathrm{CA}$ & $S$ & 15 & 442.00 & 21 & 1.41 & 0.47 \\
\hline kramer07 & $\begin{array}{l}\text { floridakey } \\
\text { s }\end{array}$ & NTA & $\mathrm{S}$ & $\mathrm{CA}$ & $\mathrm{S}$ & 1 & 1.16 & 7 & 0.47 & 0.04 \\
\hline mccook10 & GBR & NTA & $S$ & IP & $\mathrm{BACl}$ & 2 & & 2 & 1.05 & 0.12 \\
\hline newman06 & Glovers & NTA & $S$ & $\mathrm{CA}$ & $\mathrm{T}$ & & 72.80 & 6 & -0.23 & 0.13 \\
\hline stockwell09 & $\begin{array}{l}\text { guimputl } \\
\text { an }\end{array}$ & NTA & $\mathrm{C}$ & IP & $\mathrm{S}$ & & 0.13 & 7 & 3.39 & 0.12 \\
\hline friedlander06 & $\begin{array}{l}\text { Hanaum } \\
\text { a }\end{array}$ & NTA & $\mathrm{S}$ & IP & $\mathrm{S}$ & 10 & 0.41 & 37 & -0.18 & 0.02 \\
\hline roberts93 & HolChan & NTA & $S$ & $\mathrm{CA}$ & $S$ & 5 & & 4 & 0.26 & 0.03 \\
\hline friedlander06 & Honolua & NTA & $S$ & IP & $S$ & 10 & 0.18 & 24 & 1.42 & 0.03 \\
\hline friedlander06 & $\begin{array}{l}\text { Kaneohe } \\
\text { Bay }\end{array}$ & NTA & $S$ & IP & $S$ & 10 & 0.30 & 35 & 0.55 & 0.02 \\
\hline Mcc06 & Kisite & NTA & $S$ & WIO & $\mathrm{S}$ & 47 & 10.00 & 31 & 2.81 & 0.02 \\
\hline chateau05 & laregnere & NTA & $S$ & IP & $S$ & 110 & 6.49 & 14 & 0.37 & 0.03 \\
\hline $\begin{array}{l}\text { hernandezdel } \\
\text { gado07 }\end{array}$ & $\begin{array}{l}\text { LuisPena } \\
\text { Channel }\end{array}$ & NTA & $\mathrm{S}$ & $\mathrm{CA}$ & $\mathrm{BACl}$ & 30 & 4.80 & 5 & 1.09 & 0.01 \\
\hline stockwell09 & lutoban & NTA & $\mathrm{C}$ & IP & $S$ & & 0.12 & 1 & 2.25 & 0.35 \\
\hline stockwell09 & $\begin{array}{l}\text { masaplo } \\
\text { dnorte }\end{array}$ & NTA & C & IP & $\mathrm{S}$ & & 0.06 & 10 & 3.87 & 0.49 \\
\hline
\end{tabular}

ปั 


\begin{tabular}{|c|c|c|c|c|c|c|c|c|c|c|}
\hline stockwell09 & $\begin{array}{l}\text { masaplo } \\
\text { dsur }\end{array}$ & NTA & C & IP & $S$ & & 0.06 & 8 & 4.00 & 0.46 \\
\hline Bartlett09 & $\begin{array}{l}\text { permane } \\
\text { ntNorthEf } \\
\text { ate }\end{array}$ & NTA & $\mathrm{CO}$ & IP & $\mathrm{S}$ & 6 & 0.38 & 4 & 0.38 & 0.03 \\
\hline stockwell09 & $\begin{array}{l}\text { poblacion } \\
\text { l }\end{array}$ & NTA & $\mathrm{C}$ & IP & $\mathrm{S}$ & & 0.09 & 6 & 3.61 & 0.46 \\
\hline roberts93 & Saba & NTA & $S$ & $\mathrm{CA}$ & $S$ & 32 & & 4 & 0.41 & 0.09 \\
\hline hawkins06 & soufriere & NTA & $S$ & $\mathrm{CA}$ & $\mathrm{BACl}$ & 30 & & 7 & 1.49 & 0.01 \\
\hline wantiez96 & $\begin{array}{l}\text { SWNew } \\
\text { Caledoni } \\
\text { a(Noume } \\
\text { a) }\end{array}$ & NTA & $S$ & IP & $\mathrm{BACl}$ & 205 & 27.00 & 4 & 1.36 & 0.09 \\
\hline stockwell09 & tandayag & NTA & $\mathrm{C}$ & $\mathrm{IP}$ & $S$ & & 0.06 & 5 & 0.85 & 0.31 \\
\hline friedlander06 & Waikiki & NTA & $S$ & IP & $S$ & 10 & 0.32 & 14 & 1.12 & 0.10 \\
\hline friedlander06 & WaiOpae & NTA & $S$ & IP & $S$ & 10 & 0.26 & 28 & 0.63 & 0.07 \\
\hline Bartlett09 & $\begin{array}{l}\text { harveste } \\
\text { dNorthEf } \\
\text { ate }\end{array}$ & $P$ & $\mathrm{CO}$ & IP & $S$ & 6 & 0.42 & 4 & 0.56 & 0.03 \\
\hline cinner06 & $\begin{array}{l}\text { Kakarota } \\
\mathrm{n}\end{array}$ & $\mathrm{P}$ & C & IP & $\mathrm{S}$ & 87 & 0.50 & 0 & 0.32 & 0.01 \\
\hline cinner06 & Muluk & $\mathrm{P}$ & $\mathrm{C}$ & IP & $S$ & 87 & 0.58 & 60 & 0.23 & 0.01 \\
\hline friedlander06 & Waikiki & $P$ & $S$ & IP & $S$ & 10 & & & 0.42 & 0.10 \\
\hline russ96EA & Sumilon & NTA & & IP & $\mathrm{BACl}$ & 36 & & 9 & 1.89 & 0.11 \\
\hline white10 & $\begin{array}{l}\text { Daanlung } \\
\text { sod- } \\
\text { Guiwag }\end{array}$ & NTA & $\mathrm{CO}$ & IP & $S$ & 45 & 0.23 & 8 & 0.57 & 0.26 \\
\hline white10 & $\begin{array}{l}\text { Arbor(Bol } \\
\text { joon) }\end{array}$ & NTA & $\mathrm{CO}$ & IP & $S$ & 45 & 0.09 & 9 & -0.30 & 0.77 \\
\hline white10 & $\begin{array}{l}\text { Granada( } \\
\text { Boljoon) }\end{array}$ & NTA & $\mathrm{CO}$ & IP & $S$ & 45 & 0.09 & 9 & 1.90 & 0.30 \\
\hline White10 & Gawi & NTA & $\mathrm{CO}$ & IP & $S$ & & 0.13 & 7 & 2.53 & 0.65 \\
\hline White10 & Pasil & NTA & & IP & & & & 8 & 2.59 & 0.47 \\
\hline
\end{tabular}


Table A.4. Natural log of response ratio by case for fish richness.

\begin{tabular}{|c|c|c|c|c|c|c|c|c|c|c|}
\hline 1st author/year & Case & Technique & $\begin{array}{l}\text { Actor } \\
\text { group }\end{array}$ & Region & $\begin{array}{l}\text { Study } \\
\text { type }\end{array}$ & $\begin{array}{l}\text { Number } \\
\text { of } \\
\text { species }\end{array}$ & $\begin{array}{l}\text { Mgmt } \\
\text { area } \\
\left(\mathrm{km}^{\wedge} 2\right)\end{array}$ & $\begin{array}{l}\text { Years } \\
\text { managed }\end{array}$ & $\ln R$ & $\mathrm{v}(\operatorname{lnR})$ \\
\hline Ardiwijaya06 & Anoi Itam & $G$ & $\mathrm{C}$ & IP & $\mathrm{S}$ & 333 & 1.21 & & 0.24 & 0.04 \\
\hline Ardiwijaya06 & le Meulee & $G$ & $\mathrm{C}$ & IP & $S$ & 333 & 1.78 & & 0.18 & 0.04 \\
\hline Campbell07 & Kawasan Wisata & $\mathrm{G}$ & $\mathrm{S}$ & IP & $\mathrm{S}$ & & 2.07 & 9 & 0.91 & 0.03 \\
\hline friedlander06 & Kealakekua & G & $\mathrm{S}$ & IP & $\mathrm{S}$ & 10 & 1.23 & 35 & 0.21 & 0.00 \\
\hline friedlander06 & Lapakahi & $G$ & $\mathrm{~S}$ & IP & $S$ & 10 & 0.54 & 25 & 0.17 & 0.01 \\
\hline friedlander06 & Manele-Hulopoe & G & $S$ & IP & S & 10 & 1.12 & 27 & -0.05 & 0.00 \\
\hline Tyler11 & Menai & G & $\mathrm{CO}$ & WIO & $\mathrm{S}$ & 92 & 470.00 & 5 & 0.50 & 0.02 \\
\hline Bohnsack81 & $\begin{array}{l}\text { Molasses\&French } \\
\text { reefs }\end{array}$ & G & S & CA & S & 105 & & 21 & 0.07 & 0.02 \\
\hline friedlander06 & Molokini & G & $S$ & IP & $\mathrm{S}$ & 10 & 0.36 & 27 & 0.17 & 0.00 \\
\hline McCetal97 & Mvuleni Galu & G & $\mathrm{C}$ & WIO & $\mathrm{S}$ & 28 & & 20 & -0.16 & 0.02 \\
\hline friedlander06 & Old Kona & $G$ & $S$ & IP & $S$ & 10 & 1.06 & 11 & 0.17 & 0.00 \\
\hline Ardiwijaya06 & Panglima Laut & G & $\mathrm{C}$ & IP & $S$ & 333 & 2.06 & 8 & 0.12 & 0.06 \\
\hline friedlander06 & Pupukea & $G$ & $\mathrm{~S}$ & IP & $S$ & 10 & 0.72 & 20 & 0.39 & 0.01 \\
\hline jennings95 & Ste Anne & $G$ & $S$ & WIO & $S$ & 134 & 2.10 & 21 & 0.60 & 0.10 \\
\hline monaco09 & VICR & $G$ & $\mathrm{~S}$ & $\mathrm{CA}$ & $S$ & 25 & & 7 & -0.07 & 0.00 \\
\hline friedlander06 & Waialea & $\mathrm{G}$ & & IP & $S$ & 10 & 0.14 & 19 & 0.15 & 0.01 \\
\hline preuss09 & Abore & NTA & $\mathrm{S}$ & IP & $\mathrm{T}$ & 213 & 100.00 & 6 & 0.03 & 0.00 \\
\hline
\end{tabular}




\begin{tabular}{|c|c|c|c|c|c|c|c|c|c|c|}
\hline watson07 & Abrolhos & NTA & $\mathrm{S}$ & IP & $\mathrm{S}$ & 137 & & 11 & 0.19 & 0.01 \\
\hline wam01 & Apo & NTA & $\mathrm{CO}$ & IP & $\mathrm{T}$ & 126 & 0.76 & 7 & 0.08 & 0.00 \\
\hline white10 & Arbor(Boljoon) & NTA & $\mathrm{CO}$ & IP & $\mathrm{S}$ & 45 & 0.09 & 9 & 0.22 & 0.11 \\
\hline wam01 & Balicasag & NTA & $\mathrm{CO}$ & IP & $\mathrm{BACl}$ & 126 & 0.22 & 13 & 0.00 & 0.01 \\
\hline raymundo08 & Basdiot & NTA & $\mathrm{CO}$ & IP & $\mathrm{S}$ & & & 5 & 0.14 & 0.00 \\
\hline raymundo08 & Bil-isan & NTA & $\mathrm{CO}$ & IP & $S$ & & & 5 & 0.26 & 0.02 \\
\hline pittman08 & BIRNM & NTA & $\mathrm{S}$ & $\mathrm{CA}$ & $\mathrm{S}$ & & 77.00 & 5 & 0.08 & 0.00 \\
\hline jennings95 & Cousin & NTA & $\mathrm{P}$ & WIO & $\mathrm{S}$ & 134 & 0.40 & 26 & 1.32 & 0.08 \\
\hline white10 & $\begin{array}{l}\text { Daanlungsod- } \\
\text { Guiwang }\end{array}$ & NTA & $\mathrm{CO}$ & IP & $\mathrm{S}$ & 45 & 0.23 & 8 & 0.41 & 0.04 \\
\hline White10 & Gawi & NTA & $\mathrm{CO}$ & IP & $S$ & & 0.13 & 7 & 0.03 & 0.07 \\
\hline raymundo08 & Gilutungan & NTA & & IP & $\mathrm{S}$ & & & 5 & -0.01 & 0.02 \\
\hline white10 & Granada(Boljoon) & NTA & $\mathrm{CO}$ & IP & S & 45 & 0.09 & 9 & -0.32 & 0.04 \\
\hline friedlander06 & Hanauma & NTA & $\mathrm{S}$ & IP & $\mathrm{S}$ & 10 & 0.41 & 37 & 0.21 & 0.00 \\
\hline tkachenko10 & hobihu(nanwan) & NTA & $\mathrm{CO}$ & IP & $\mathrm{S}$ & 68 & 1.50 & 2 & -0.79 & 0.03 \\
\hline svensson09 & hon ong WIB & NTA & $\mathrm{P}$ & IP & S & 242 & 0.11 & 6 & 0.85 & 0.01 \\
\hline svensson09 & hon ong WIBP & NTA & $\mathrm{P}$ & IP & $\mathrm{BACl}$ & 242 & 0.05 & 1.5 & 0.12 & 0.03 \\
\hline friedlander06 & Honolua & NTA & $S$ & IP & $S$ & 10 & 0.18 & 24 & 0.32 & 0.00 \\
\hline friedlander06 & Kaneohe Bay & NTA & $\mathrm{S}$ & IP & $\mathrm{S}$ & 10 & 0.30 & 35 & 0.45 & 0.01 \\
\hline chateau05 & laregnere & NTA & $\mathrm{S}$ & IP & $\mathrm{S}$ & 110 & 6.49 & 14 & 0.20 & 0.00 \\
\hline hernandezdelgado07 & $\begin{array}{l}\text { Luis Pena } \\
\text { Channel }\end{array}$ & NTA & $S$ & $\mathrm{CA}$ & $\mathrm{BACl}$ & 30 & 4.80 & 5 & -0.11 & 0.01 \\
\hline raymundo08 & Maayong & NTA & & IP & $\mathrm{S}$ & & & 5 & 0.85 & 0.27 \\
\hline
\end{tabular}




\begin{tabular}{|c|c|c|c|c|c|c|c|c|c|c|}
\hline goetze11 & namena & NTA & $\mathrm{C}$ & IP & $S$ & 341 & 60.60 & 12 & 0.09 & 0.00 \\
\hline goetze11 & namuri & NTA & $\mathrm{C}$ & IP & $\mathrm{S}$ & 341 & 4.25 & 4 & -0.02 & 0.00 \\
\hline wam01 & Pamilican & NTA & C & IP & $\mathrm{BACl}$ & 126 & 1.35 & 14 & -0.05 & 0.01 \\
\hline raymundo08 & Saavedra & NTA & & IP & $S$ & & & 5 & 0.06 & 0.01 \\
\hline hawkins06 & soufriere & NTA & $\mathrm{S}$ & $\mathrm{CA}$ & $\mathrm{BACl}$ & 30 & & 7 & 0.17 & 0.00 \\
\hline wam01 & Sumilon & NTA & $\mathrm{CO}$ & IP & RT & 126 & 0.23 & 4 & 0.16 & 0.00 \\
\hline wantiez96 & $\begin{array}{l}\text { SW New } \\
\text { Caledonia } \\
\text { (Noumea) }\end{array}$ & NTA & $\mathrm{S}$ & IP & $\mathrm{BACl}$ & 205 & 27.00 & 4 & 0.45 & 0.01 \\
\hline raymundo08 & Talima & NTA & & IP & $S$ & & & 5 & 0.41 & 0.01 \\
\hline raymundo08 & Tawala & NTA & & IP & $\mathrm{S}$ & & & 5 & -0.03 & 0.01 \\
\hline friedlander06 & Waikiki & NTA & & IP & $S$ & 10 & 0.32 & 14 & 0.27 & 0.02 \\
\hline friedlander06 & WaiOpae & NTA & & IP & $S$ & 10 & 0.26 & 28 & 0.03 & 0.00 \\
\hline raymundo08 & Zaragosa & NTA & & IP & $\mathrm{S}$ & & & 5 & 0.61 & 0.22 \\
\hline cinner06 & Kakarotan & $\mathrm{P}$ & C & IP & $\mathrm{S}$ & 87 & 0.50 & 0 & -0.06 & 0.01 \\
\hline cinner06 & Muluk & $\mathrm{P}$ & $\mathrm{C}$ & IP & $S$ & 87 & 0.58 & 60 & -0.03 & 0.02 \\
\hline friedlander06 & Waikiki & $\mathrm{P}$ & & IP & $S$ & 10 & & 14 & 0.20 & 0.02 \\
\hline friedlander06 & Kealakekua & & $\mathrm{S}$ & IP & & 10 & & 35 & -0.04 & 0.00 \\
\hline friedlander06 & Old Kona & & & IP & & 10 & & 11 & -0.46 & 0.00 \\
\hline White10 & Pasil & NTA & & IP & & & & & 0.76 & 0.14 \\
\hline
\end{tabular}


Table A.5. Raw data for coral cover.

\begin{tabular}{|c|c|c|c|c|c|c|c|c|c|c|}
\hline 1st author/year & Case & Technique & $\begin{array}{l}\text { Actor } \\
\text { group }\end{array}$ & $\begin{array}{l}\text { control } \\
\mathrm{n}\end{array}$ & $\begin{array}{l}\text { control } \\
\text { mean }\end{array}$ & $\begin{array}{l}\text { control } \\
\text { SD }\end{array}$ & $\begin{array}{l}\text { treatment } \\
\mathrm{n}\end{array}$ & $\begin{array}{l}\text { treatment } \\
\text { mean }\end{array}$ & $\begin{array}{l}\text { treatment } \\
\text { SD }\end{array}$ & $\begin{array}{l}\text { BACl: } \\
\text { B/A }\end{array}$ \\
\hline campbell12 & Anoi Itam & $G$ & $\mathrm{C}$ & 3 & 19.56 & 11.16 & 3 & 54.67 & 9.24 & \\
\hline wam01 & Apo & $G$ & $\mathrm{CO}$ & 2 & 36.18 & 16.96 & 2 & 35.36 & 18.18 & \\
\hline campbell12 & le Meulee & $\mathrm{G}$ & $\mathrm{C}$ & 3 & 19.56 & 11.16 & 2 & 60.00 & 8.80 & \\
\hline campbell12 & Kawasan Wisata & G & $\mathrm{CO}$ & 3 & 19.56 & 11.16 & 4 & 41.78 & 8.89 & \\
\hline Campbell07 & Kawasan Wisata & G & s & 2 & 11.60 & 15.56 & 2 & 28.80 & 5.94 & \\
\hline friedlander06 & Kealakekua & G & S & 13 & 30.30 & & 34 & 29.00 & & \\
\hline friedlander10 & Kealakekua & G & S & 13 & 33.52 & & 22 & 45.32 & & \\
\hline friedlander06 & Lapakahi & $G$ & $S$ & 26 & 21.30 & & 28 & 17.10 & & \\
\hline kamukuru04 & mafia & $\mathrm{G}$ & $\mathrm{S}$ & 2 & 15.61 & 2.75 & 2 & 26.78 & 3.93 & \\
\hline friedlander06 & Manele-Hulopoe & G & s & 40 & 12.90 & & 33 & 20.00 & & \\
\hline Coles & Manele-Hulopoe & $G$ & S & 2 & 2.60 & 1.35 & 2 & 24.20 & 6.93 & \\
\hline Tyler11 & Menai & $G$ & $\mathrm{CO}$ & 5 & 41.45 & 23.32 & 5 & 29.97 & 11.87 & \\
\hline friedlander06 & Molokini & $G$ & $S$ & 32 & 21.80 & & 38 & 28.50 & & \\
\hline Coles & Molokini & $G$ & $S$ & 4 & 3.38 & 2.29 & 2 & 32.40 & 2.26 & \\
\hline McCetal97 & Mvuleni Galu & $G$ & $\mathrm{C}$ & 3 & 9.60 & 8.90 & 2 & 9.90 & 5.00 & \\
\hline friedlander06 & Old Kona & $\mathrm{G}$ & $S$ & 20 & 21.50 & & 21 & 24.30 & & \\
\hline campbell12 & Panglima Laut & G & C & 3 & 19.56 & 11.16 & 3 & 26.22 & 7.70 & \\
\hline friedlander06 & Pupukea & $G$ & $S$ & 38 & 3.70 & & 35 & 10.30 & & \\
\hline friedlander10 & Pupukea & $\mathrm{G}$ & $S$ & 2 & 10.94 & 0.65 & 2 & 14.41 & 6.43 & \\
\hline
\end{tabular}




\begin{tabular}{|c|c|c|c|c|c|c|c|c|c|c|}
\hline Cros\&McC03 & Ras Iwatine & $\mathrm{G}$ & $S$ & 9 & 13.90 & 5.40 & 12 & 5.50 & 3.60 & \\
\hline Mcc06 & Tanga & $\mathrm{G}$ & $\mathrm{C}$ & 7 & 19.70 & 6.61 & 4 & 27.80 & 8.60 & \\
\hline monaco09 & VICR & G & $S$ & 2 & 6.24 & 1.17 & 2 & 2.55 & & \\
\hline friedlander06 & Waialea & $\mathrm{G}$ & $S$ & 46 & 18.60 & & 34 & 13.80 & & \\
\hline stockwell09 & andulay & NTA & $\mathrm{C}$ & 4 & 25.50 & 2.80 & 6 & 37.30 & 9.55 & \\
\hline wam01 & Apo & NTA & $\mathrm{CO}$ & 2 & 35.52 & 2.94 & 2 & 35.06 & 12.09 & \\
\hline raymundo08 & Apo & NTA & $\mathrm{CO}$ & 4.5 & 65.26 & 35.66 & 4.5 & 66.64 & 15.00 & \\
\hline White10 & Arbor(Boljoon) & NTA & $\mathrm{CO}$ & & 22.00 & & & 34.80 & & \\
\hline stockwell09 & ave maria & NTA & $\mathrm{C}$ & 6 & 43.00 & 6.12 & 6 & 40.20 & 6.61 & \\
\hline wam01 & Balicasag & NTA & $\mathrm{CO}$ & 2 & 30.96 & 4.40 & 2 & 31.67 & 1.24 & $B$ \\
\hline wam01 & Balicasag & NTA & $\mathrm{CO}$ & 2 & 27.64 & 13.37 & 2 & 32.14 & 8.25 & A \\
\hline raymundo08 & Balicasag & NTA & $\mathrm{CO}$ & 4.5 & 29.57 & 7.53 & 4.5 & 21.68 & 7.51 & \\
\hline stockwell09 & baobaon & NTA & $\mathrm{C}$ & 2 & 46.25 & 3.45 & 6 & 47.80 & 9.80 & \\
\hline raymundo08 & Basdiot & NTA & & 4.5 & 78.11 & 8.44 & 4.5 & 76.84 & 17.84 & \\
\hline stockwell09 & baylimango & NTA & $\mathrm{C}$ & 6 & 8.70 & 5.39 & 6 & 52.80 & 11.02 & \\
\hline raymundo08 & Bil-isan & NTA & & 4.5 & 75.80 & 5.64 & 4.5 & 69.22 & 7.50 & \\
\hline stockwell09 & bio-os & NTA & $\mathrm{C}$ & 6 & 32.70 & 9.55 & 6 & 39.80 & 10.53 & \\
\hline miller09 & BIRNM & NTA & $S$ & 20 & 6.00 & 3.58 & 20 & 4.10 & 1.79 & \\
\hline pittman08 & BIRNM & NTA & $\mathrm{S}$ & 80 & 0.80 & 0.94 & 95 & 3.87 & 7.88 & \\
\hline stockwell09 & bongalonan & NTA & C & 6 & 30.00 & 6.12 & 6 & 33.30 & 6.12 & \\
\hline nanola04 & Cabacongan & NTA & $\mathrm{CO}$ & 6 & 38.00 & & 4 & 72.60 & & \\
\hline stockwell09 & canlucani & NTA & C & 6 & 26.00 & 5.63 & 6 & 18.70 & 5.39 & \\
\hline stockwell09 & carang & NTA & $\mathrm{C}$ & 6 & 52.50 & 8.33 & 6 & 30.70 & 10.53 & \\
\hline White10 & Colase & NTA & $\mathrm{CO}$ & 3 & 31.39 & 13.11 & 3 & 45.17 & 4.40 & \\
\hline
\end{tabular}




\begin{tabular}{|c|c|c|c|c|c|c|c|c|c|c|}
\hline White10 & $\begin{array}{l}\text { Daanlungsod- } \\
\text { Guiwang }\end{array}$ & NTA & $\mathrm{CO}$ & 10 & 5.52 & 7.91 & 10 & 33.00 & 15.18 & \\
\hline epstein & Eilat & NTA & $\mathrm{S}$ & 2 & 0.77 & 0.08 & 1 & 2.40 & & \\
\hline kramer07 & floridakeys & NTA & $S$ & 2 & 47.13 & 5.92 & 3 & 20.50 & 5.77 & \\
\hline White10 & Gawi & NTA & $\mathrm{CO}$ & & 58.30 & & & 51.00 & & $B$ \\
\hline White10 & Gawi & NTA & $\mathrm{CO}$ & 4 & 40.60 & 13.00 & 6 & 48.80 & 21.07 & $A$ \\
\hline evans04 & GBR & NTA & $S$ & 3 & 37.48 & 4.28 & 3 & 41.19 & 4.06 & \\
\hline nanola04 & Gilutungan & NTA & $\mathrm{CO}$ & 4 & 34.40 & & 6 & 48.40 & & \\
\hline raymundo08 & Gilutungan & NTA & & 4.5 & 50.47 & 15.94 & 4.5 & 56.27 & 15.01 & \\
\hline White10 & Granada(Boljoon) & NTA & $\mathrm{CO}$ & 2 & 34.50 & 6.36 & 8 & 33.75 & 11.88 & \\
\hline Kopp10 & Guadelupe & NTA & S & & 18.10 & & & 25.60 & & \\
\hline stockwell09 & guimputlan & NTA & C & 6 & 54.30 & 10.04 & 6 & 50.50 & 10.29 & \\
\hline friedlander06 & Hanauma & NTA & $\mathrm{S}$ & 47 & 4.70 & & 33 & 14.50 & & \\
\hline friedlander10 & Hanauma & NTA & $\mathrm{S}$ & 3 & 5.95 & 7.91 & 2 & 22.72 & 21.77 & \\
\hline tkachenko10 & hobihu(nanwan) & NTA & $\mathrm{CO}$ & 6 & 38.28 & 9.06 & 2 & 35.50 & 5.17 & \\
\hline brownsaracino07 & hol chan & NTA & $S$ & 7 & 37.04 & 5.58 & 15 & 43.60 & 13.56 & \\
\hline friedlander06 & Honolua & NTA & $S$ & 63 & 1.80 & & 37 & 3.50 & & \\
\hline friedlander10 & Honolua & NTA & $S$ & 3 & 14.45 & 15.12 & 2 & 22.42 & 15.11 & \\
\hline friedlander06 & Kaneohe Bay & NTA & S & 74 & 17.50 & & 30 & 32.20 & & \\
\hline Mcc06 & Kisite & NTA & $\mathrm{S}$ & 7 & 19.70 & 6.61 & 3 & 32.70 & 10.05 & \\
\hline nanola04 & Lomboy-Kahayag & NTA & $\mathrm{CO}$ & 5 & 15.90 & & 4 & 15.60 & & \\
\hline
\end{tabular}

ธิ 


\begin{tabular}{|c|c|c|c|c|c|c|c|c|c|c|}
\hline stockwell09 & lutoban & NTA & $\mathrm{C}$ & 6 & 10.80 & 7.84 & 6 & 30.70 & 6.37 & \\
\hline raymundo08 & Maayong & NTA & & 4.5 & 35.28 & 17.83 & 4.5 & 38.00 & 24.41 & \\
\hline Muthiga09 & Malindi\&Watamu & NTA & $\mathrm{S}$ & 2 & 24.46 & & 2 & 13.25 & & \\
\hline Dumas10 & Mangorongo & NTA & $\mathrm{CO}$ & 13 & 32.70 & 9.11 & 7 & 28.40 & 9.30 & \\
\hline Dumas10 & Marow & NTA & $\mathrm{CO}$ & 18 & 25.10 & 12.82 & 22 & 18.90 & 9.94 & \\
\hline stockwell09 & masaplod norte & NTA & $\mathrm{C}$ & 6 & 22.80 & 9.31 & 6 & 26.70 & 10.78 & \\
\hline stockwell09 & masaplod sur & NTA & C & 6 & 22.80 & 9.31 & 6 & 33.00 & 10.29 & \\
\hline poonian08 & misali (pemba) & NTA & $\mathrm{CO}$ & 2 & 18.87 & 1.67 & 3 & 22.79 & 1.62 & \\
\hline Cros\&McC03 & MombasaMNP & NTA & $\mathrm{S}$ & 9 & 13.90 & 5.40 & 18 & 23.60 & 9.70 & \\
\hline aswani07 & Nusa Hope & NTA & $\mathrm{C}$ & 3 & 4.69 & 0.50 & 3 & 5.07 & 2.18 & \\
\hline page09 & Palau & NTA & & & 48.30 & & & 46.40 & & \\
\hline wam01 & Pamilican & NTA & $\mathrm{C}$ & 2 & 7.43 & 3.85 & 2 & 6.63 & 9.87 & \\
\hline stockwell09 & poblacion I & NTA & C & 6 & 22.80 & 9.31 & 6 & 67.30 & 8.82 & \\
\hline nanola04 & Port Barton & NTA & $\mathrm{CO}$ & 3 & 33.20 & & 3 & 32.20 & & \\
\hline raymundo08 & Saavedra & NTA & & 4.5 & 62.06 & 9.39 & 4.5 & 65.23 & 4.66 & \\
\hline nanola04 & Sibulan & NTA & $\mathrm{CO}$ & 4 & 9.40 & & 4 & 19.10 & & \\
\hline hawkins06 & soufriere & NTA & $S$ & & 20.63 & & & 35.92 & & $B$ \\
\hline hawkins06 & soufriere & NTA & $S$ & & 13.35 & & & 19.42 & & $A$ \\
\hline wam01 & Sumilon & NTA & $\mathrm{CO}$ & 2 & 24.08 & 19.18 & 2 & 22.07 & 17.17 & \\
\hline white84 & Sumilon & NTA & $\mathrm{CO}$ & 2 & 22.20 & 8.91 & 2 & 33.25 & 17.47 & \\
\hline White10 & Sumilon & NTA & $\mathrm{CO}$ & & 31.35 & & & 44.60 & & \\
\hline raymundo08 & Talima & NTA & & 4.5 & 14.07 & 9.37 & 4.5 & 14.13 & 2.79 & \\
\hline
\end{tabular}




\begin{tabular}{|c|c|c|c|c|c|c|c|c|c|}
\hline stockwell09 & tandayag & NTA & $\mathrm{C}$ & 6 & 32.70 & 9.55 & 6 & 41.70 & 12.25 \\
\hline raymundo08 & Tawala & NTA & & 4.5 & 71.93 & 20.65 & 4.5 & 80.84 & 6.58 \\
\hline white91 & Tubbataha & NTA & $\mathrm{CO}$ & 5 & 23.80 & 6.54 & 2 & 25.90 & 1.77 \\
\hline nanola04 & Tuka & NTA & $\mathrm{CO}$ & 5 & 46.70 & & 5 & 60.70 & \\
\hline miller09 & VINP & NTA & $\mathrm{S}$ & 20 & 6.00 & 3.58 & 3 & 10.40 & 1.51 \\
\hline friedlander06 & Waikiki & NTA & $S$ & 58 & 2.00 & & 21 & 1.00 & \\
\hline friedlander06 & WaiOpae & NTA & $S$ & 28 & 14.50 & & 29 & 16.70 & \\
\hline Kuo12 & Wanlitung & NTA & $S$ & 1 & 47.50 & & 3 & 17.69 & 5.09 \\
\hline raymundo08 & Zaragosa & NTA & & 4.5 & 84.96 & 4.69 & 4.5 & 82.80 & 6.57 \\
\hline cinner06 & Kakarotan & $\mathrm{P}$ & C & 3 & 4.00 & 3.64 & 3 & 5.20 & 0.52 \\
\hline cinner06 & Muluk & $\mathrm{P}$ & C & 5 & 40.80 & 10.06 & 5 & 35.30 & 9.39 \\
\hline friedlander06 & Waikiki & $\mathrm{P}$ & $S$ & 58 & 2.00 & & 20 & 1.00 & \\
\hline grigg94 & Hanauma & & & & & & & & \\
\hline friedlander06 & Kealakekua & & $\mathrm{S}$ & 13 & 30.30 & & 29 & 37.50 & \\
\hline friedlander10 & Kealakekua & & $\mathrm{S}$ & 13 & 33.52 & & 29 & 37.33 & \\
\hline friedlander06 & Old Kona & & $S$ & 20 & 21.50 & & 32 & 13.80 & \\
\hline White10 & Pasil & NTA & & 5 & 10.90 & 11.40 & 10 & 29.40 & 22.77 \\
\hline roberts92 & Sinai & $\mathrm{P}$ & $S$ & & 28.80 & & & 14.70 & \\
\hline
\end{tabular}


Table A.6. Raw data for fish abundance.

\begin{tabular}{|c|c|c|c|c|c|c|c|c|c|c|}
\hline 1st author/year & Case & $\begin{array}{l}\text { Techniqu } \\
\mathrm{e}\end{array}$ & $\begin{array}{l}\text { Actor } \\
\text { grou } \\
\mathrm{p}\end{array}$ & $\begin{array}{l}\text { contro } \\
\text { In }\end{array}$ & $\begin{array}{l}\text { control } \\
\text { mean }\end{array}$ & $\begin{array}{l}\text { control } \\
\text { SD }\end{array}$ & $\begin{array}{l}\text { treatmen } \\
\mathrm{t} n\end{array}$ & $\begin{array}{l}\text { treatment } \\
\text { mean }\end{array}$ & $\begin{array}{l}\text { treatment } \\
\text { SD }\end{array}$ & $\begin{array}{l}\mathrm{BACl} \\
: \mathrm{B} / \mathrm{A}\end{array}$ \\
\hline williams09 & West hawaii & & S & 9 & 11.90 & 5.70 & 9 & 13.40 & 3.60 & B \\
\hline williams09 & West hawaii & & S & 9 & 6.30 & 3.90 & 9 & 23.00 & 9.90 & A \\
\hline tissot04 & West hawaii & & S & 6 & 45.29 & 3.52 & 6 & 54.76 & 2.73 & B \\
\hline tissot04 & West hawaii & & $S$ & 6 & 52.65 & 5.86 & 6 & 65.96 & 3.71 & $A$ \\
\hline tissot04 & West hawaii & & $S$ & 6 & 74.73 & 8.05 & 6 & 43.73 & 5.07 & $\mathrm{~B}$ \\
\hline tissot04 & West hawaii & & S & 6 & 80.29 & 8.16 & 6 & 50.00 & 7.38 & $\mathrm{~A}$ \\
\hline russ89 & Sumilon & NTA & $\mathrm{CO}$ & 6 & 8720.47 & 3068.20 & 6 & 9105.02 & 5271.05 & A \\
\hline russ89 & Sumilon & NTA & $\mathrm{CO}$ & 6 & 8443.89 & 3832.08 & 6 & 14709.12 & 2188.76 & $\mathrm{~B}$ \\
\hline friedlander10 & Kealakekua & & $S$ & 13 & 1.26 & & 29 & 0.94 & & \\
\hline Ardiwijaya06 & Anoi Itam & GR & C & 6 & $\begin{array}{r}13393.0 \\
5\end{array}$ & $\begin{array}{r}12323.3 \\
6 \\
\end{array}$ & 6 & 4214.48 & 66964.24 & \\
\hline abesamis 05 & Apo & GR & $\mathrm{CO}$ & 6 & 1.80 & 0.90 & 6 & 6.80 & & \\
\hline floeter06 & $\begin{array}{l}\text { Arraial de Cabo } \\
\text { Pedra Vermelha }\end{array}$ & GR & S & & 18.68 & & & 30.18 & & \\
\hline amargos 10 & Cuba & GR & $S$ & 6 & 108.03 & 7.57 & 6 & 105.03 & 7.57 & \\
\hline fonesca06 & DTNP & GR & $S$ & 20 & 2862.00 & & 20 & 3342.00 & & \\
\hline karnauskas & Glovers & GR & $S$ & 39 & 32.17 & 16.54 & 39 & 27.61 & 13.62 & \\
\hline Ardiwijaya06 & le Meulee & GR & $C$ & 6 & 13393.0 & 12323.3 & 4 & 104129.6 & 117284.9 & \\
\hline
\end{tabular}




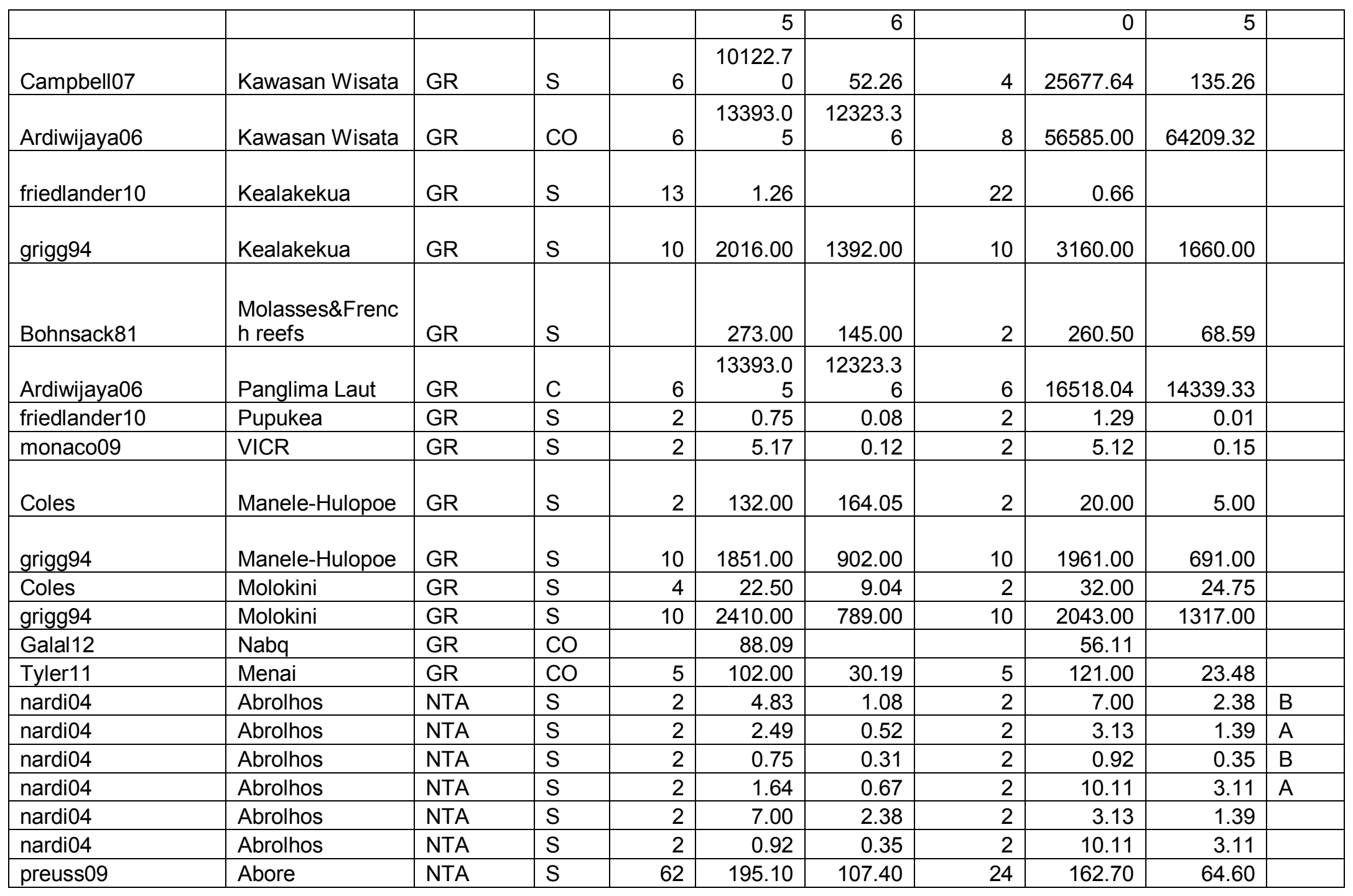




\begin{tabular}{|c|c|c|c|c|c|c|c|c|c|c|}
\hline floeter06 & $\begin{array}{l}\text { Abrolhos } \\
\text { Arquipelago }\end{array}$ & NTA & $\mathrm{S}$ & & 32.11 & & & 24.81 & & \\
\hline abesamis06 & Apo & NTA & & 6 & 26.90 & 4.65 & 6 & 67.90 & 21.56 & \\
\hline abesamis06 & Apo & NTA & & 6 & 97.06 & 41.61 & 6 & 136.69 & 43.48 & \\
\hline White10 & Arbor(Boljoon) & NTA & $\mathrm{CO}$ & 6 & 1017.42 & 240.48 & 6 & 1825.45 & 1616.33 & \\
\hline floeter06 & Arvoredo & NTA & $\mathrm{S}$ & & 18.68 & & & 9.45 & & \\
\hline wam01 & Balicasag & NTA & $\mathrm{CO}$ & 7 & 4785.00 & 727.69 & 3 & 4296.00 & 89.37 & $B$ \\
\hline wam01 & Balicasag & NTA & $\mathrm{CO}$ & 5 & 3290.00 & 602.42 & 5 & 4370.00 & 954.36 & A \\
\hline abesamis06 & Balicasag & NTA & $\mathrm{CO}$ & 8 & 44.36 & 18.53 & 8 & 34.99 & 23.85 & \\
\hline abesamis06 & Balicasag & NTA & $\mathrm{CO}$ & 8 & 36.59 & 22.99 & 8 & 53.96 & 40.08 & \\
\hline chapman99 & Barbados & NTA & $S$ & 10 & 95.19 & 12.50 & 10 & 51.10 & 7.84 & \\
\hline pittman08 & BIRNM & NTA & $S$ & 80 & 146.80 & 100.27 & 95 & 150.64 & 99.81 & \\
\hline nanola04 & Cabacongan & NTA & $\mathrm{CO}$ & 7 & 1566.00 & & 1 & 3557.00 & & B \\
\hline nanola04 & Cabacongan & NTA & $\mathrm{CO}$ & 6 & 2087.00 & & 4 & 2515.00 & & A \\
\hline White10 & Colase & NTA & $\mathrm{CO}$ & 6 & 742.27 & 568.18 & 6 & 3804.13 & 4772.71 & \\
\hline White10 & $\begin{array}{l}\text { Daanlungsod- } \\
\text { Guiwang }\end{array}$ & NTA & $\mathrm{CO}$ & 6 & 303.70 & 1651.94 & 6 & 1947.30 & 1651.94 & \\
\hline Hamilton 11 & Dyual (site1) & NTA & $\mathrm{CO}$ & 2 & 0.28 & 0.21 & 3 & 7.29 & 9.85 & \\
\hline Hamilton 11 & Dyual (site1) & NTA & $\mathrm{CO}$ & 2 & 0.51 & 0.39 & 3 & 10.50 & 11.61 & \\
\hline Hamilton 11 & Dyual (site1) & NTA & $\mathrm{CO}$ & 2 & 8.10 & 1.57 & 3 & 6.81 & 8.78 & \\
\hline kellner & exuma & NTA & $\mathrm{S}$ & 3 & 1.67 & 0.45 & 3 & 2.81 & 0.99 & \\
\hline kramer07 & floridakeys & NTA & $\mathrm{S}$ & 2 & 0.48 & 0.06 & 2 & 0.82 & 0.24 & \\
\hline
\end{tabular}




\begin{tabular}{|c|c|c|c|c|c|c|c|c|c|c|}
\hline kramer07 & floridakeys & NTA & $\mathrm{S}$ & 2 & 0.19 & 0.05 & 2 & 0.09 & 0.01 & \\
\hline kramer07 & floridakeys & NTA & $S$ & 2 & 0.50 & 0.06 & 2 & 0.42 & 0.03 & \\
\hline smith11 & floridakeys & NTA & $S$ & & 0.00 & & & 0.00 & & $\mathrm{~B}$ \\
\hline smith11 & floridakeys & NTA & $\mathrm{S}$ & & 0.00 & & & 0.04 & & A \\
\hline White10 & Gawi & NTA & $\mathrm{CO}$ & 6 & 663.80 & 739.07 & 6 & 804.60 & 739.07 & B \\
\hline White10 & Gawi & NTA & $\mathrm{CO}$ & 6 & 1850.58 & 788.34 & 6 & 1589.08 & 936.15 & $A$ \\
\hline russ08 & GBR & NTA & $\mathrm{S}$ & 3 & 7.28 & 2.66 & 3 & 8.61 & 3.83 & $B$ \\
\hline russ08 & GBR & NTA & $\mathrm{S}$ & 3 & 6.30 & 2.56 & 3 & 9.87 & 3.79 & $A$ \\
\hline mccook10 & GBR & NTA & $\mathrm{S}$ & 5 & 12.32 & 4.08 & 5 & 19.77 & 8.04 & \\
\hline graham03 & GBR & NTA & $S$ & 2 & 1119.13 & 129.67 & 2 & 528.58 & 75.28 & \\
\hline evans04 & GBR & NTA & $S$ & 3 & 5.33 & 1.36 & 3 & 8.32 & 1.71 & \\
\hline evans04 & GBR & NTA & $\mathrm{S}$ & 3 & 10.28 & 2.65 & 3 & 14.44 & 3.49 & \\
\hline evans04 & GBR & NTA & $\mathrm{S}$ & 3 & 19.29 & 3.31 & 3 & 19.33 & 3.19 & \\
\hline nanola04 & Gilutungan & NTA & $\mathrm{CO}$ & 4 & 70.00 & & 6 & 2121.00 & & \\
\hline karnauskas & Glovers & NTA & $S$ & 17 & 33.07 & 13.24 & 17 & 22.11 & 8.40 & \\
\hline White10 & $\begin{array}{l}\text { Granada(Boljoon } \\
\text { ) }\end{array}$ & NTA & $\mathrm{CO}$ & & 1688.24 & & & 2264.71 & & \\
\hline Kopp10 & Guadelupe & NTA & $\mathrm{S}$ & & 86.30 & & & 87.40 & & \\
\hline friedlander10 & Hanauma & NTA & $\mathrm{S}$ & 3 & 0.21 & 0.18 & 2 & 0.53 & 0.19 & \\
\hline grigg94 & Hanauma & NTA & $S$ & 10 & 1403.00 & 1193.00 & 10 & 1793.00 & 446.00 & \\
\hline craik82 & Heron(GBR) & NTA & $\mathrm{S}$ & 4 & 23.25 & 19.45 & & 98.00 & & \\
\hline tkachenko10 & hobihu(nanwan) & NTA & $\mathrm{CO}$ & 51 & 6.05 & 3.29 & 19 & 11.12 & 5.60 & \\
\hline
\end{tabular}




\begin{tabular}{|c|c|c|c|c|c|c|c|c|c|c|}
\hline brownsaracino07 & hol chan & NTA & $\mathrm{S}$ & 9 & 59.53 & 17.68 & 9 & 144.80 & 38.40 & \\
\hline polunin93 & hol chan & NTA & $\mathrm{S}$ & 3 & 2.50 & 0.55 & & 4.40 & & \\
\hline polunin93 & hol chan & NTA & $S$ & 3 & 0.63 & 0.32 & & 1.20 & & \\
\hline polunin93 & hol chan & NTA & $\mathrm{S}$ & 3 & 14.00 & 4.48 & & 6.80 & & \\
\hline svensson09 & hon ong WIB & NTA & $\mathrm{P}$ & 2 & 0.67 & 0.12 & 8 & 2.44 & 0.68 & \\
\hline svensson09 & hon ong WIBP & NTA & $\mathrm{P}$ & 2 & 0.42 & 0.09 & 8 & 0.68 & 0.15 & $B$ \\
\hline svensson09 & hon ong WIBP & NTA & $\mathrm{P}$ & 2 & 0.67 & 0.12 & 8 & 1.75 & 1.14 & A \\
\hline friedlander10 & Honolua & NTA & $\mathrm{S}$ & 3 & 0.49 & 0.36 & 2 & 1.15 & 0.06 & \\
\hline grigg94 & Honolua & NTA & $\mathrm{S}$ & 10 & 1019.00 & 311.00 & 10 & 2795.00 & 772.00 & \\
\hline aswani10 & Kida & NTA & $\mathrm{C}$ & 26 & 17.14 & 5.53 & 26 & 34.93 & 14.76 & \\
\hline floeter06 & Laje de Santos & NTA & S & & 18.68 & & & 8.19 & & \\
\hline chateau05 & laregnere & NTA & $\mathrm{S}$ & 2 & 74.38 & 11.17 & 12 & 75.32 & 27.07 & \\
\hline letourneur96 & longogori & NTA & $\mathrm{S}$ & 3 & 905.10 & 191.80 & 3 & 751.40 & 259.10 & \\
\hline $\begin{array}{l}\text { hernandezdelgado0 } \\
7\end{array}$ & $\begin{array}{l}\text { Luis Pena } \\
\text { Channel }\end{array}$ & NTA & $\mathrm{S}$ & 2 & 93.00 & 33.94 & 2 & 130.00 & 46.67 & $\mathrm{~B}$ \\
\hline $\begin{array}{l}\text { hernandezdelgado0 } \\
7\end{array}$ & $\begin{array}{l}\text { Luis Pena } \\
\text { Channel }\end{array}$ & NTA & $\mathrm{S}$ & 2 & 408.50 & 4.95 & 2 & 503.00 & 53.74 & A \\
\hline Muthiga09 & Malindi\&Watamu & NTA & $\mathrm{S}$ & 2 & 285.92 & & 2 & 412.63 & & \\
\hline goetze11 & namena & NTA & C & 2 & 4.37 & 1.75 & 2 & 7.91 & 3.11 & \\
\hline goetze11 & namena & NTA & C & 2 & 2.33 & 0.00 & 2 & 6.17 & 2.17 & \\
\hline goetze11 & namena & NTA & C & 2 & 9.52 & 1.37 & 2 & 15.74 & 6.00 & \\
\hline goetze11 & namena & NTA & C & 2 & 52.12 & 18.30 & 2 & 48.81 & 4.47 & \\
\hline
\end{tabular}




\begin{tabular}{|c|c|c|c|c|c|c|c|c|c|c|}
\hline goetze11 & namuri & NTA & $\mathrm{C}$ & 2 & 3.64 & 0.33 & 2 & 4.30 & 2.16 & \\
\hline goetze11 & namuri & NTA & $\mathrm{C}$ & 2 & 2.97 & 1.42 & 2 & 2.38 & 0.76 & \\
\hline goetze11 & namuri & NTA & C & 2 & 9.23 & 1.25 & 2 & 10.74 & 3.38 & \\
\hline goetze11 & namuri & NTA & C & 2 & 44.2074 & $\begin{array}{r}8.16126 \\
2 \\
\end{array}$ & 2 & $\begin{array}{r}41.93100 \\
2 \\
\end{array}$ & 8.720526 & \\
\hline aswani10 & Nusa Hope & NTA & C & 18 & 17.7814 & $\begin{array}{r}9.23601 \\
7 \\
\end{array}$ & 18 & $\begin{array}{r}48.74499 \\
1 \\
\end{array}$ & $\begin{array}{r}16.93900 \\
5 \\
\end{array}$ & \\
\hline aswani07 & Nusa Hope & NTA & C & 3 & 61 & $\begin{array}{r}31.1769 \\
1 \\
\end{array}$ & 3 & 134 & 43.30127 & \\
\hline aswani07 & Nusa Hope & NTA & & 3 & 175 & $\begin{array}{r}53.6935 \\
8 \\
\end{array}$ & 3 & 247 & $\begin{array}{r}53.69357 \\
5 \\
\end{array}$ & \\
\hline nanola04 & Port Barton & NTA & $\mathrm{CO}$ & 3 & 996 & & 3 & 675 & & \\
\hline nemeth05 & red hind bank & NTA & $\mathrm{S}$ & 48 & 184 & & 49 & 253 & & \\
\hline polunin93 & saba & NTA & $\mathrm{S}$ & & 13.6 & & & 18.6 & & \\
\hline nanola04 & Sibulan & NTA & $\mathrm{CO}$ & 4 & 685 & & 4 & 725 & & \\
\hline wantiez96 & $\begin{array}{l}\text { SW New } \\
\text { Caledonia } \\
\text { (Noumea) }\end{array}$ & NTA & $S$ & 6 & 0.322 & $\begin{array}{r}0.34782 \\
8 \\
\end{array}$ & 5 & $\begin{array}{r}0.384130 \\
2 \\
\end{array}$ & $\begin{array}{r}0.175960 \\
9 \\
\end{array}$ & B \\
\hline wantiez96 & $\begin{array}{l}\text { SW New } \\
\text { Caledonia } \\
\text { (Noumea) }\end{array}$ & NTA & $\mathrm{S}$ & 6 & 0.608 & $\begin{array}{r}0.38946 \\
9 \\
\end{array}$ & 5 & $\begin{array}{r}0.984918 \\
7 \\
\end{array}$ & $\begin{array}{r}0.439792 \\
2 \\
\end{array}$ & A \\
\hline fonesca06 & TER & NTA & $\mathrm{S}$ & 20 & 15763 & & 20 & 10882 & & B \\
\hline fonesca06 & TER & NTA & $\mathrm{S}$ & 20 & 2862 & & 20 & 5577 & & A \\
\hline Hamilton 11 & Tigak (site 10) & NTA & $\mathrm{CO}$ & 2 & 0.27556 & $\begin{array}{r}0.20541 \\
2 \\
\end{array}$ & 2 & $\begin{array}{r}5.523950 \\
6 \\
\end{array}$ & $\begin{array}{r}6.540067 \\
4 \\
\end{array}$ & \\
\hline Hamilton 11 & Tigak (site 10) & NTA & $\mathrm{CO}$ & 2 & 0.51361 & $\begin{array}{r}0.38783 \\
4 \\
\end{array}$ & 2 & $\begin{array}{r}1.126394 \\
3 \\
\end{array}$ & 1.742752 & \\
\hline
\end{tabular}




\begin{tabular}{|c|c|c|c|c|c|c|c|c|c|c|}
\hline Hamilton 11 & Tigak (site 10) & NTA & $\mathrm{CO}$ & 2 & 8.10468 & $\begin{array}{r}1.57361 \\
8 \\
\end{array}$ & 2 & $\begin{array}{r}9.900122 \\
9 \\
\end{array}$ & $\begin{array}{r}9.927815 \\
5 \\
\end{array}$ & \\
\hline white91 & Tubbataha & NTA & $\mathrm{CO}$ & 5 & 18.4 & 5.55 & 36 & 43.93 & & \\
\hline nanola04 & Tuka & NTA & $\mathrm{CO}$ & 5 & 1167 & & 5 & 2698 & & \\
\hline wam01 & Apo & NTA & $\mathrm{CO}$ & 4 & 2142 & $\begin{array}{r}564.345 \\
7 \\
\end{array}$ & 5 & 5214 & 1272.486 & \\
\hline abesamis05 & Apo & NTA & $\mathrm{CO}$ & 6 & 6.2 & $\begin{array}{r}2.13105 \\
6 \\
\end{array}$ & 6 & 18.2 & $\begin{array}{r}4.800999 \\
9\end{array}$ & \\
\hline Galal02 & Nabq & NTA & $\mathrm{CO}$ & 10 & 30.9 & 10.2 & 10 & 42 & 25.8 & \\
\hline Galal12 & Nabq & NTA & $\mathrm{CO}$ & & 90.3483 & & & $\begin{array}{r}108.7279 \\
5 \\
\end{array}$ & & \\
\hline Galal02 & Nabq & NTA & $\mathrm{CO}$ & 10 & 9.6 & 3.3 & 10 & 14.1 & 5.2 & \\
\hline Galal02 & Nabq & NTA & $\mathrm{CO}$ & 10 & 50 & 14.8 & 10 & 58.6 & 21.7 & \\
\hline wam01 & Pamilican & NTA & C & 11 & 2593 & $\begin{array}{r}1309.89 \\
6\end{array}$ & 3 & 2477 & $\begin{array}{r}827.6513 \\
8\end{array}$ & B \\
\hline wam01 & Pamilican & NTA & C & 1 & 833 & & 3 & 2523 & $\begin{array}{r}526.5408 \\
6 \\
\end{array}$ & A \\
\hline wam01 & Sumilon & NTA & $\mathrm{CO}$ & 2 & 4491 & $\begin{array}{r}61.8833 \\
7 \\
\end{array}$ & 2 & 2580 & $\begin{array}{r}19.81158 \\
2 \\
\end{array}$ & \\
\hline cinner06 & Kakarotan & $\mathrm{P}$ & C & 3 & 2026.7 & $\begin{array}{r}620.420 \\
6 \\
\end{array}$ & 3 & 1971.1 & $\begin{array}{r}195.3753 \\
3\end{array}$ & \\
\hline feary11 & Muluk & $\mathrm{P}$ & C & 4 & 2.80135 & $\begin{array}{r}2.42411 \\
5\end{array}$ & 4 & 1.847467 & $\begin{array}{r}1.842827 \\
6\end{array}$ & \\
\hline feary 11 & Muluk & $\mathrm{P}$ & C & 4 & 25.73 & $\begin{array}{r}5.47281 \\
4\end{array}$ & 4 & $\begin{array}{r}47.02139 \\
6\end{array}$ & $\begin{array}{r}15.83405 \\
2\end{array}$ & \\
\hline feary11 & Muluk & $\mathrm{P}$ & C & 4 & 3.88975 & 3.64545 & 4 & $\begin{array}{r}0.817863 \\
9 \\
\end{array}$ & $\begin{array}{r}1.212057 \\
9 \\
\end{array}$ & \\
\hline feary 11 & Muluk & $\mathrm{P}$ & C & 4 & 5.81143 & $\begin{array}{r}3.63617 \\
4\end{array}$ & 4 & $\begin{array}{r}5.777413 \\
9 \\
\end{array}$ & $\begin{array}{r}4.257663 \\
3\end{array}$ & \\
\hline feary11 & Muluk & $P$ & C & 4 & 14.7241 & $\begin{array}{r}7.30945 \\
2\end{array}$ & 4 & $\begin{array}{r}8.909597 \\
4\end{array}$ & $\begin{array}{r}6.103578 \\
2\end{array}$ & \\
\hline feary11 & Muluk & $\mathrm{P}$ & C & 4 & 7.19819 & $\begin{array}{r}3.04869 \\
7 \\
\end{array}$ & 4 & $\begin{array}{r}4.126298 \\
7 \\
\end{array}$ & 2.442668 & \\
\hline
\end{tabular}




\begin{tabular}{|c|c|c|c|c|c|c|c|c|c|}
\hline feary11 & Muluk & $\mathrm{P}$ & C & 4 & 1.1951 & $\begin{array}{r}2.44266 \\
8\end{array}$ & 4 & $\begin{array}{r}32.24016 \\
7\end{array}$ & $\begin{array}{r}38.98682 \\
7\end{array}$ \\
\hline cinner06 & Muluk & $\mathrm{P}$ & C & 5 & 3004 & $\begin{array}{r}884.141 \\
3 \\
\end{array}$ & 5 & 3065.3 & $\begin{array}{r}1134.580 \\
9 \\
\end{array}$ \\
\hline Bartlett09 & $\begin{array}{l}\text { harvested North } \\
\text { Efate }\end{array}$ & $\mathrm{P}$ & $\mathrm{CO}$ & 36 & 2253 & 1074 & 36 & 3448 & 2250 \\
\hline Bartlett09 & $\begin{array}{l}\text { harvested North } \\
\text { Efate }\end{array}$ & $\mathrm{P}$ & $\mathrm{CO}$ & 36 & 2110 & 1068 & 36 & 2153 & 858 \\
\hline Bartlett09 & $\begin{array}{l}\text { permanent North } \\
\text { Efate }\end{array}$ & NTA & $\mathrm{CO}$ & 36 & 2609 & 1260 & 36 & 3381 & 1764 \\
\hline Bartlett09 & $\begin{array}{l}\text { permanent North } \\
\text { Efate }\end{array}$ & NTA & $\mathrm{CO}$ & 36 & 2468 & 960 & 36 & 2281 & 918 \\
\hline page09 & Palau & NTA & & & 38.1 & & & 36.85 & \\
\hline White10 & Pasil & NTA & & 6 & 715.239 & $\begin{array}{r}583.983 \\
8\end{array}$ & 6 & $\begin{array}{r}2264.906 \\
1\end{array}$ & $\begin{array}{r}1897.947 \\
6\end{array}$ \\
\hline roberts92 & Sinai & $P$ & $S$ & & 27.3 & & & 23.2 & \\
\hline White10 & Sumilon & & & & 3566.1 & & & 2074.1 & \\
\hline
\end{tabular}


Table A.7. Raw data for fish biomass.

\begin{tabular}{|c|c|c|c|c|c|c|c|c|c|c|}
\hline $\begin{array}{l}\text { 1st } \\
\text { author/year }\end{array}$ & Case & $\begin{array}{l}\text { Tech } \\
\text { niqu } \\
\text { e }\end{array}$ & $\begin{array}{l}\text { Actor } \\
\text { group }\end{array}$ & $\begin{array}{l}\text { contr } \\
\text { ol n }\end{array}$ & $\begin{array}{l}\text { control } \\
\text { mean }\end{array}$ & control SD & $\begin{array}{l}\text { treat } \\
\text { ment } \\
\mathrm{n}\end{array}$ & $\begin{array}{l}\text { treatment } \\
\text { mean }\end{array}$ & treatment SD & $\begin{array}{l}\mathrm{BACl} \\
: \mathrm{B} / \mathrm{A}\end{array}$ \\
\hline cinner05 & Ahus & $G$ & C & 3 & 127.00 & 22.52 & 3 & 205.00 & 34.64 & \\
\hline campbell12 & Anoi Itam & G & C & 3 & 2.55 & 0.17 & 3 & 2.99 & 0.11 & \\
\hline russ03 & Apo & $G$ & $\mathrm{CO}$ & 6 & 1.24 & & 6 & 1.86 & & \\
\hline alcala05 & Apo & $G$ & $\mathrm{CO}$ & 6 & 33.70 & 34.05 & 6 & 45.50 & 24.25 & \\
\hline newman06 & DTNP & G & $\mathrm{S}$ & & 112.57 & & 8 & 87.28 & 43.89 & \\
\hline newman06 & Glovers & $G$ & $S$ & 3 & 109.08 & 47.56 & 6 & 57.19 & 12.53 & \\
\hline campbell12 & le Meulee & G & C & 3 & 2.55 & 0.17 & 2 & 3.01 & 0.28 & \\
\hline campbell12 & $\begin{array}{l}\text { Kawasan } \\
\text { Wisata }\end{array}$ & G & $\mathrm{CO}$ & 3 & 2.55 & 0.17 & 4 & 2.93 & 0.14 & \\
\hline $\begin{array}{l}\text { friedlander0 } \\
6\end{array}$ & $\begin{array}{l}\text { Kealakek } \\
\text { ua }\end{array}$ & $\mathrm{G}$ & $S$ & 13 & 0.57 & 0.22 & 2 & 0.76 & 0.30 & \\
\hline $\begin{array}{l}\text { friedlander1 } \\
0\end{array}$ & $\begin{array}{l}\text { Kealakek } \\
\text { ua }\end{array}$ & $\mathrm{G}$ & $S$ & 13 & 0.61 & & 22 & 0.82 & & \\
\hline grigg94 & $\begin{array}{l}\text { Kealakek } \\
\text { ua }\end{array}$ & G & S & 10 & 47.00 & 4.20 & 10 & 194.00 & 86.10 & \\
\hline $\begin{array}{l}\text { friedlander0 } \\
6\end{array}$ & Lapakahi & G & $\mathrm{s}$ & 2 & 0.48 & 0.09 & 2 & 0.75 & 0.09 & \\
\hline $\begin{array}{l}\text { kamukuru0 } \\
4\end{array}$ & mafia & G & $S$ & & & & & & & \\
\hline $\begin{array}{l}\text { friedlander0 } \\
6\end{array}$ & $\begin{array}{l}\text { Manele- } \\
\text { Hulopoe }\end{array}$ & G & $S$ & 3 & 0.45 & 0.13 & 3 & 0.63 & 0.17 & \\
\hline Coles & $\begin{array}{l}\text { Manele- } \\
\text { Hulopoe }\end{array}$ & G & $S$ & & 8.50 & & & 17.40 & & \\
\hline grigg94 & $\begin{array}{l}\text { Manele- } \\
\text { Hulopoe }\end{array}$ & G & S & 10 & 64.00 & 31.70 & 10 & 79.50 & 30.20 & \\
\hline
\end{tabular}




\begin{tabular}{|c|c|c|c|c|c|c|c|c|c|}
\hline Tyler11 & Menai & $G$ & $\mathrm{CO}$ & 5 & 21.20 & 3.13 & 5 & 29.60 & 13.42 \\
\hline $\begin{array}{l}\text { friedlander0 } \\
6\end{array}$ & Molokini & G & $\mathrm{S}$ & 3 & 0.15 & 0.05 & 2 & 1.23 & 0.35 \\
\hline Coles & Molokini & $G$ & $\mathrm{~S}$ & 2 & 32.30 & 26.30 & & 43.20 & \\
\hline grigg94 & Molokini & $G$ & $S$ & 10 & 101.00 & 29.80 & 10 & 107.00 & 54.30 \\
\hline McCetal97 & $\begin{array}{l}\text { Mvuleni } \\
\text { Galu }\end{array}$ & G & C & 3 & 65.20 & 34.60 & 2 & 72.90 & 15.70 \\
\hline $\begin{array}{l}\text { friedlander0 } \\
6\end{array}$ & Old Kona & G & $S$ & 2 & 0.95 & 0.15 & 2 & 1.52 & 0.25 \\
\hline campbell12 & $\begin{array}{l}\text { Panglima } \\
\text { Laut }\end{array}$ & G & C & 3 & 2.55 & 0.17 & 3 & 2.36 & 0.15 \\
\hline $\begin{array}{l}\text { friedlander0 } \\
6\end{array}$ & Pupukea & G & $\mathrm{S}$ & 3 & 0.17 & 0.08 & 3 & 0.63 & 0.24 \\
\hline $\begin{array}{l}\text { friedlander1 } \\
0\end{array}$ & Pupukea & G & $\mathrm{S}$ & 2 & 0.18 & 0.01 & 2 & 0.86 & 0.02 \\
\hline jennings95 & Ste Anne & G & $\mathrm{S}$ & 15 & 23.81 & 17.77 & 3 & 53.31 & 27.02 \\
\hline Mcc06 & Tanga & G & C & 14 & 81.90 & 33.67 & 8 & 457.40 & 22.34 \\
\hline monaco09 & VICR & G & $\mathrm{S}$ & 2 & 7.97 & 0.16 & 2 & 8.19 & 0.19 \\
\hline $\begin{array}{l}\text { friedlander0 } \\
6 \\
\end{array}$ & Waialea & G & $S$ & 3 & 0.29 & 0.07 & 3 & 0.45 & 0.16 \\
\hline preuss09 & Abore & NTA & $S$ & 62 & 21.80 & 17.00 & 24 & 15.20 & 11.90 \\
\hline stockwell09 & andulay & NTA & C & 4 & 5.50 & 2.53 & 6 & 14.30 & 11.02 \\
\hline roberts 97 & $\begin{array}{l}\text { Anse } \\
\text { Chastane } \\
\mathrm{t}\end{array}$ & NTA & $\mathrm{P}$ & & 1.85 & & & 4.15 & \\
\hline russ03 & Apo & NTA & $\mathrm{CO}$ & 6 & 8.68 & & 6 & 37.83 & \\
\hline alcala05 & Apo & NTA & $\mathrm{CO}$ & 6 & 94.10 & 33.56 & 6 & 164.70 & 67.36 \\
\hline stockwell09 & ave maria & NTA & C & 6 & 1.50 & 1.71 & 6 & 32.40 & 3.92 \\
\hline stockwell09 & baobaon & NTA & $\mathrm{C}$ & 2 & 3.95 & 1.01 & 6 & 6.30 & 5.88 \\
\hline stockwell09 & $\begin{array}{l}\text { bayliman } \\
\text { go }\end{array}$ & NTA & C & 6 & 4.00 & 2.20 & 6 & 7.50 & 2.20 \\
\hline stockwell09 & bio-os & NTA & $\mathrm{C}$ & 6 & 8.60 & 4.16 & 6 & 5.90 & 2.20 \\
\hline
\end{tabular}




\begin{tabular}{|c|c|c|c|c|c|c|c|c|c|c|}
\hline pittman08 & BIRNM & NTA & $S$ & 80 & 4284.39 & 5021.67 & 95 & 5985.86 & 7536.51 & \\
\hline stockwell09 & $\begin{array}{l}\text { bongalon } \\
\text { an }\end{array}$ & NTA & C & 6 & 3.30 & 3.92 & 6 & 32.40 & 26.45 & \\
\hline stockwell09 & canlucani & NTA & C & 6 & 0.70 & 0.98 & 6 & 8.50 & 3.92 & \\
\hline stockwell09 & carang & NTA & $\mathrm{C}$ & 6 & 3.10 & 3.18 & 6 & 12.80 & 7.10 & \\
\hline jennings95 & Cousin & NTA & $\mathrm{P}$ & 15 & 23.81 & 17.77 & 3 & 58.69 & 26.73 & \\
\hline harborne09 & exuma & NTA & $\mathrm{S}$ & 6 & 2588.96 & 1627.59 & 3 & 10554.31 & 11672.00 & \\
\hline lamb10 & exuma & NTA & $\mathrm{S}$ & & 70.60 & & & 487.50 & & \\
\hline mumby06 & Exuma & NTA & $\mathrm{S}$ & 2 & 2102.56 & 1598.09 & & 4075.18 & & \\
\hline mumby06 & Exuma & NTA & $\mathrm{S}$ & 2 & 703.18 & 142.08 & & 1215.36 & & \\
\hline kramer07 & $\begin{array}{l}\text { floridakey } \\
\text { s }\end{array}$ & NTA & $\mathrm{S}$ & 30 & 127.58 & 494.95 & 48 & 1185.38 & 2688.42 & \\
\hline kramer07 & $\begin{array}{l}\text { floridakey } \\
\text { s }\end{array}$ & NTA & $\mathrm{S}$ & 30 & 106.31 & 320.26 & 48 & 584.72 & 1436.28 & \\
\hline kramer07 & $\begin{array}{l}\text { floridakey } \\
\text { s }\end{array}$ & NTA & $\mathrm{S}$ & 30 & 2511.63 & 2165.41 & 48 & 2418.61 & 3061.30 & \\
\hline kramer07 & $\begin{array}{l}\text { floridakey } \\
\text { s }\end{array}$ & NTA & $\mathrm{S}$ & 30 & 23.26 & & 48 & 906.98 & 2739.06 & \\
\hline kramer07 & $\begin{array}{l}\text { floridakey } \\
\text { s }\end{array}$ & NTA & $\mathrm{S}$ & 30 & 302.33 & 636.89 & 48 & 674.42 & 1288.97 & \\
\hline mccook10 & GBR & NTA & $S$ & 3 & 7.18 & 1.17 & 3 & 7.52 & 2.13 & $B$ \\
\hline mccook10 & GBR & NTA & $S$ & 3 & 4.58 & 1.33 & 3 & 11.20 & 2.23 & $A$ \\
\hline mccook10 & GBR & NTA & $\mathrm{S}$ & 5 & 3.58 & 1.31 & 5 & 7.97 & 3.00 & \\
\hline graham03 & GBR & NTA & $\mathrm{S}$ & 2 & 3420.00 & 892.37 & 2 & 9790.00 & 1971.41 & \\
\hline evans04 & GBR & NTA & $\mathrm{S}$ & 3 & 1.96 & 0.80 & 3 & 8.12 & 2.49 & \\
\hline evans04 & GBR & NTA & $\mathrm{S}$ & 3 & 2.03 & 0.49 & 3 & 5.34 & 1.47 & \\
\hline newman06 & Glovers & NTA & $\mathrm{S}$ & 3 & 109.08 & 47.56 & 2 & 86.80 & 32.59 & \\
\hline Kopp10 & $\begin{array}{l}\text { Guadelup } \\
\mathrm{e}\end{array}$ & NTA & $S$ & & 3283.00 & & & 5645.00 & & \\
\hline stockwell09 & $\begin{array}{l}\text { guimputla } \\
\text { n }\end{array}$ & NTA & C & 6 & 1.00 & 0.73 & 6 & 29.70 & 12.00 & \\
\hline
\end{tabular}




\begin{tabular}{|c|c|c|c|c|c|c|c|c|c|c|}
\hline $\begin{array}{l}\text { friedlander0 } \\
6\end{array}$ & Hanauma & NTA & S & 4 & 0.11 & 0.04 & 3 & 0.65 & 0.21 & \\
\hline $\begin{array}{l}\text { friedlander1 } \\
0\end{array}$ & Hanauma & NTA & S & 3 & 0.17 & 0.20 & 2 & 0.89 & 0.07 & \\
\hline grigg94 & Hanauma & NTA & $\mathrm{S}$ & 10 & 106.00 & 40.00 & 10 & 77.60 & 23.10 & \\
\hline polunin93 & hol chan & NTA & $S$ & 3 & 3155.00 & 498.00 & & 5993.00 & & \\
\hline newman06 & hol chan & NTA & $S$ & 3 & 109.08 & 47.56 & & 108.61 & & \\
\hline roberts93 & Hol Chan & NTA & $S$ & 6 & 2.26 & 0.95 & 2 & 2.93 & 0.04 & \\
\hline $\begin{array}{l}\text { friedlander0 } \\
6\end{array}$ & Honolua & NTA & S & 3 & 0.20 & 0.05 & 3 & 0.67 & 0.19 & \\
\hline $\begin{array}{l}\text { friedlander1 } \\
0\end{array}$ & Honolua & NTA & S & 3 & 0.26 & 0.09 & 2 & 1.09 & 0.15 & \\
\hline grigg94 & Honolua & NTA & $S$ & 10 & 24.00 & 13.20 & 10 & 93.00 & 29.80 & \\
\hline $\begin{array}{l}\text { friedlander0 } \\
6\end{array}$ & $\begin{array}{l}\text { Kaneohe } \\
\text { Bay }\end{array}$ & NTA & $\mathrm{S}$ & 3 & 0.38 & 0.07 & 2 & 0.66 & 0.11 & \\
\hline Mcc06 & Kisite & NTA & $\mathrm{S}$ & 14 & 81.90 & 33.67 & 6 & 1354.20 & 218.25 & \\
\hline chateau05 & laregnere & NTA & $S$ & 2 & 59.42 & 10.50 & 12 & 86.21 & 40.36 & \\
\hline $\begin{array}{l}\text { letourneur9 } \\
6\end{array}$ & longogori & NTA & $S$ & 3 & 15912.00 & & 3 & 40438.00 & & \\
\hline newman06 & Looe key & NTA & $S$ & & 112.57 & & & 190.97 & & \\
\hline $\begin{array}{l}\text { hernandezd } \\
\text { elgado07 }\end{array}$ & $\begin{array}{l}\text { Luis Pena } \\
\text { Channel }\end{array}$ & NTA & $\mathrm{S}$ & 2 & 3.88 & 1.49 & 2 & 2.70 & 0.12 & $\mathrm{~B}$ \\
\hline $\begin{array}{l}\text { hernandezd } \\
\text { elgado07 }\end{array}$ & $\begin{array}{l}\text { Luis Pena } \\
\text { Channel }\end{array}$ & NTA & $S$ & 2 & 5.98 & 0.24 & 2 & 8.03 & 0.73 & A \\
\hline stockwell09 & lutoban & NTA & $\mathrm{C}$ & 6 & 0.40 & 0.49 & 6 & 3.80 & 2.94 & \\
\hline Muthiga09 & $\begin{array}{l}\text { Malindi\& } \\
\text { Watamu }\end{array}$ & NTA & $\mathrm{S}$ & 2 & 152.40 & & 2 & 1421.05 & & \\
\hline stockwell09 & $\begin{array}{l}\text { masaplod } \\
\text { norte }\end{array}$ & NTA & $\mathrm{C}$ & 6 & 0.60 & 0.98 & 6 & 28.80 & 15.19 & \\
\hline
\end{tabular}




\begin{tabular}{|c|c|c|c|c|c|c|c|c|c|c|}
\hline stockwell09 & $\begin{array}{l}\text { masaplod } \\
\text { sur }\end{array}$ & NTA & C & 6 & 0.60 & 0.98 & 6 & 32.70 & 11.02 & \\
\hline page09 & Palau & NTA & & & 9537.31 & & & 16291.13 & & \\
\hline Bartlett09 & $\begin{array}{l}\text { permanen } \\
\text { t North } \\
\text { Efate }\end{array}$ & NTA & $\mathrm{CO}$ & 36 & 296.00 & 378.00 & 36 & 508.00 & 558.00 & \\
\hline Bartlett09 & $\begin{array}{l}\text { permanen } \\
\text { t North } \\
\text { Efate }\end{array}$ & NTA & $\mathrm{CO}$ & 36 & 261.00 & 144.00 & 36 & 307.00 & 186.00 & \\
\hline stockwell09 & poblacion & NTA & C & 6 & 0.60 & 0.98 & 6 & 22.10 & 7.35 & \\
\hline polunin93 & saba & NTA & $\mathrm{S}$ & & 1843.00 & & & 3525.00 & & \\
\hline roberts93 & Saba & NTA & $S$ & 10 & 0.41 & 0.31 & 10 & 0.61 & 0.35 & \\
\hline hawkins06 & soufriere & NTA & $\mathrm{S}$ & 83 & 2.51 & 3.41 & 114 & 2.14 & 1.71 & $B$ \\
\hline hawkins06 & soufriere & NTA & $S$ & 83 & 5.35 & 4.87 & 114 & 9.52 & 6.85 & A \\
\hline roberts 01 & Soufriere & NTA & $\mathrm{CO}$ & & 2.28 & & & 1.97 & & $\mathrm{~B}$ \\
\hline roberts 01 & Soufriere & NTA & $\mathrm{CO}$ & & 3.68 & & & 5.02 & & A \\
\hline wantiez96 & $\begin{array}{l}\text { SW New } \\
\text { Caledonia } \\
\text { (Noumea) }\end{array}$ & NTA & $S$ & 6 & 42.98 & 63.64 & 5 & 40.91 & 14.73 & B \\
\hline wantiez96 & $\begin{array}{l}\text { SW New } \\
\text { Caledonia } \\
\text { (Noumea) }\end{array}$ & NTA & $\mathrm{S}$ & 6 & 42.78 & 36.94 & 5 & 160.01 & 89.73 & A \\
\hline stockwell09 & tandayag & NTA & $\mathrm{C}$ & 6 & 8.60 & 4.16 & 6 & 20.10 & 25.72 & \\
\hline $\begin{array}{l}\text { friedlander0 } \\
6\end{array}$ & Waikiki & NTA & $\mathrm{S}$ & 4 & 0.13 & 0.03 & 2 & 0.41 & 0.17 & \\
\hline $\begin{array}{l}\text { friedlander0 } \\
6\end{array}$ & WaiOpae & NTA & $\mathrm{S}$ & 2 & 0.24 & 0.07 & 2 & 0.45 & 0.12 & \\
\hline
\end{tabular}




\begin{tabular}{|c|c|c|c|c|c|c|c|c|c|c|}
\hline newman06 & $\begin{array}{l}\text { western } \\
\text { sambo } \\
\text { (FKNMS) }\end{array}$ & NTA & $S$ & & 112.57 & & & 98.60 & & \\
\hline Bartlett09 & $\begin{array}{l}\text { harvested } \\
\text { North } \\
\text { Efate }\end{array}$ & $\mathrm{P}$ & $\mathrm{CO}$ & 36 & 175.00 & 180.00 & 36 & 669.00 & 750.00 & \\
\hline Bartlett09 & $\begin{array}{l}\text { harvested } \\
\text { North } \\
\text { Efate }\end{array}$ & $\mathrm{P}$ & $\mathrm{CO}$ & 36 & 381.00 & 234.00 & 36 & 307.00 & 186.00 & \\
\hline cinner06 & $\begin{array}{l}\text { Kakarota } \\
\mathrm{n}\end{array}$ & $\mathrm{P}$ & C & 3 & 101.30 & 18.01 & 3 & 139.10 & 7.97 & \\
\hline cinner06 & Muluk & $\mathrm{P}$ & $\mathrm{C}$ & 5 & 301.10 & 63.50 & 5 & 377.60 & 27.28 & \\
\hline $\begin{array}{l}\text { friedlander0 } \\
6\end{array}$ & Waikiki & $\mathrm{P}$ & $S$ & 4 & 0.13 & 0.03 & 2 & 0.20 & 0.08 & \\
\hline $\begin{array}{l}\text { friedlander0 } \\
6\end{array}$ & $\begin{array}{l}\text { Kealakek } \\
\text { ua }\end{array}$ & & $S$ & 13 & 0.572774 & 0.217 & 29 & 0.571593 & 0.35094 & \\
\hline $\begin{array}{l}\text { friedlander1 } \\
0\end{array}$ & $\begin{array}{l}\text { Kealakek } \\
\text { ua }\end{array}$ & & $S$ & 13 & 0.609612 & & 29 & 0.641052 & & \\
\hline $\begin{array}{l}\text { friedlander0 } \\
6\end{array}$ & Old Kona & & & 2 & 0.950928 & 0.151 & 3 & 0.46773 & 0.122111 & \\
\hline russ96EA & Sumilon & NTA & & 6 & 0.991194 & 1.133 & 6 & 2.669344 & 1.937971 & $A$ \\
\hline russ96EA & Sumilon & & & 6 & 1.718064 & 0.486 & 6 & 17.70076 & 6.624421 & $B$ \\
\hline roberts 92 & Sinai & $\mathrm{P}$ & $S$ & & 9651.1 & & & 6404 & & \\
\hline white10 & $\begin{array}{l}\text { Daanlung } \\
\text { sod- } \\
\text { Guiwag }\end{array}$ & NTA & $\mathrm{CO}$ & 6 & 5.344415 & 4.397 & 6 & 9.458035 & 8.850376 & \\
\hline white10 & $\begin{array}{l}\text { Arbor(Bolj } \\
\text { oon) }\end{array}$ & NTA & $\mathrm{CO}$ & 6 & 17.41976 & 28.77 & 6 & 12.93587 & 17.73827 & \\
\hline white10 & $\begin{array}{l}\text { Granada( } \\
\text { Boljoon) }\end{array}$ & NTA & $\mathrm{CO}$ & 6 & 2.81141 & 3.302 & 6 & 18.70671 & 12.14034 & \\
\hline White10 & Gawi & NTA & $\mathrm{CO}$ & 6 & 1.774711 & 3.327 & 6 & 22.17942 & 13.25992 & \\
\hline White10 & Sumilon & & & 6 & 30.12069 & 49.82 & 6 & 35.16888 & 44.25184 & \\
\hline
\end{tabular}


Table A.8. Raw data for fish richness.

\begin{tabular}{|c|c|c|c|c|c|c|c|c|c|c|}
\hline $\begin{array}{l}\text { 1st } \\
\text { author/year }\end{array}$ & Case & $\begin{array}{l}\text { Tech } \\
\text { niqu } \\
\text { e }\end{array}$ & $\begin{array}{l}\text { Actor } \\
\text { group }\end{array}$ & $\begin{array}{l}\text { contr } \\
\text { ol n }\end{array}$ & $\begin{array}{l}\text { control } \\
\text { mean }\end{array}$ & control SD & $\begin{array}{l}\text { treatme } \\
\text { nt } n\end{array}$ & $\begin{array}{l}\text { treatme } \\
\text { nt } \\
\text { mean }\end{array}$ & $\begin{array}{l}\text { treatment } \\
\text { SD }\end{array}$ & $\begin{array}{l}\text { BAC } \\
\text { I: } \\
\text { B/A }\end{array}$ \\
\hline $\begin{array}{l}\text { Ardiwijaya0 } \\
6\end{array}$ & Anoi Itam & G & C & 3 & 203.35 & 71.66 & 3 & 259.52 & 25.12 & \\
\hline russ11 & Apo & $G$ & $\mathrm{CO}$ & 6 & 0.14 & & 6 & 4.32 & & \\
\hline $\begin{array}{l}\text { Ardiwijaya0 } \\
6\end{array}$ & le Meulee & G & C & 3 & 203.35 & 71.66 & 2 & 243.62 & 4.56 & \\
\hline $\begin{array}{l}\text { Campbell0 } \\
7\end{array}$ & $\begin{array}{l}\text { Kawasan } \\
\text { Wisata }\end{array}$ & G & $S$ & 24 & 48.70 & 25.20 & 4 & 44.30 & 5.82 & \\
\hline $\begin{array}{l}\text { Ardiwijaya0 } \\
6\end{array}$ & $\begin{array}{l}\text { Kawasan } \\
\text { Wisata }\end{array}$ & $G$ & $\mathrm{CO}$ & 3 & 203.35 & 71.66 & 4 & 283.74 & 41.21 & \\
\hline $\begin{array}{l}\text { friedlander0 } \\
6 \\
\end{array}$ & $\begin{array}{l}\text { Kealakek } \\
\text { ua }\end{array}$ & G & $S$ & 13 & 20.47 & 3.15 & 2 & 10.39 & 0.89 & \\
\hline $\begin{array}{l}\text { friedlander1 } \\
0\end{array}$ & $\begin{array}{l}\text { Kealakek } \\
\text { ua }\end{array}$ & G & $S$ & 13 & 21.58 & & 22 & 18.35 & & \\
\hline grigg94 & $\begin{array}{l}\text { Kealakek } \\
\text { ua }\end{array}$ & G & $S$ & 10 & 40.50 & 2.10 & 10 & 41.30 & 1.20 & \\
\hline $\begin{array}{l}\text { friedlander0 } \\
6\end{array}$ & Lapakahi & G & $S$ & 2 & 19.33 & 1.56 & 2 & 22.95 & 1.66 & \\
\hline $\begin{array}{l}\text { friedlander0 } \\
6\end{array}$ & $\begin{array}{l}\text { Manele- } \\
\text { Hulopoe }\end{array}$ & G & $S$ & 3 & 14.69 & 1.50 & 3 & 13.74 & 1.58 & \\
\hline Coles & $\begin{array}{l}\text { Manele- } \\
\text { Hulopoe }\end{array}$ & G & $S$ & 2 & 9.50 & 4.95 & 2 & 6.50 & 0.71 & \\
\hline grigg94 & $\begin{array}{l}\text { Manele- } \\
\text { Hulopoe }\end{array}$ & $\mathrm{G}$ & $S$ & 10 & 45.60 & 5.90 & 10 & 44.00 & 4.80 & \\
\hline Tyler11 & Menai & $G$ & $\mathrm{CO}$ & 5 & 14.00 & 3.80 & 5 & 23.00 & 4.92 & \\
\hline $\begin{array}{l}\text { Bohnsack8 } \\
1\end{array}$ & $\begin{array}{l}\text { Molasses } \\
\text { \&French } \\
\text { reefs }\end{array}$ & G & $\mathrm{S}$ & 2 & 21.00 & 4.00 & 2 & 22.50 & 2.12 & \\
\hline
\end{tabular}




\begin{tabular}{|c|c|c|c|c|c|c|c|c|c|c|}
\hline $\begin{array}{l}\text { friedlander0 } \\
6\end{array}$ & Molokini & $\mathrm{G}$ & $\mathrm{S}$ & 3 & 10.63 & 2.84 & 2 & 16.45 & 1.19 & \\
\hline Coles & Molokini & $G$ & $S$ & 4 & 11.00 & 4.69 & 4 & 10.50 & 3.54 & \\
\hline grigg94 & Molokini & $G$ & $S$ & 10 & 37.30 & 1.50 & 10 & 42.60 & 3.20 & \\
\hline McCetal97 & $\begin{array}{l}\text { Mvuleni } \\
\text { Galu }\end{array}$ & $\mathrm{G}$ & C & 3 & 23.20 & 5.60 & 2 & 19.80 & 1.80 & \\
\hline $\begin{array}{l}\text { friedlander0 } \\
6\end{array}$ & Old Kona & G & $\mathrm{S}$ & 2 & 23.47 & 1.16 & 2 & 27.79 & 1.60 & \\
\hline $\begin{array}{l}\text { Campbell0 } \\
7\end{array}$ & $\begin{array}{l}\text { Panglima } \\
\text { Laut }\end{array}$ & $\mathrm{G}$ & C & 24 & 48.70 & 26.80 & 3 & 36.00 & 5.99 & \\
\hline $\begin{array}{l}\text { Ardiwijaya0 } \\
6\end{array}$ & $\begin{array}{l}\text { Panglima } \\
\text { Laut }\end{array}$ & $\mathrm{G}$ & C & 3 & 203.35 & 71.66 & 3 & 228.33 & 47.76 & \\
\hline $\begin{array}{l}\text { friedlander0 } \\
6\end{array}$ & Pupukea & G & $S$ & 3 & 11.27 & 1.65 & 3 & 17.11 & 1.40 & \\
\hline $\begin{array}{l}\text { friedlander1 } \\
0\end{array}$ & Pupukea & $\mathrm{G}$ & $\mathrm{S}$ & 2 & 15.50 & 2.09 & 2 & 22.25 & & \\
\hline jennings95 & Ste Anne & $G$ & $S$ & 15 & 0.55 & 0.33 & 3 & 1.00 & 0.47 & \\
\hline Mcc06 & Tanga & $G$ & C & & & & & 41.10 & & \\
\hline monaco09 & VICR & $G$ & $S$ & 2 & 24.90 & 1.07 & 2 & 23.30 & 0.92 & \\
\hline $\begin{array}{l}\text { friedlander0 } \\
6\end{array}$ & Waialea & G & & 3 & 9.20 & 1.14 & 3 & 10.67 & 1.36 & \\
\hline preuss09 & Abore & NTA & $S$ & 62 & 20.60 & 6.55 & 24 & 21.20 & 5.60 & \\
\hline watson07 & Abrolhos & NTA & $S$ & 2 & 6.90 & 0.44 & 2 & 8.37 & 0.71 & \\
\hline wam01 & Apo & NTA & $\mathrm{CO}$ & 4 & 44.00 & 3.64 & 5 & 56.00 & 4.67 & \\
\hline $\begin{array}{l}\text { raymundo0 } \\
8\end{array}$ & Apo & NTA & $\mathrm{CO}$ & 3 & 72.14 & 7.76 & 3 & 68.16 & 3.45 & \\
\hline russ11 & Apo & NTA & $\mathrm{CO}$ & 6 & 0.64 & & 6 & 7.45 & & \\
\hline white10 & $\begin{array}{l}\text { Arbor(Bolj } \\
\text { oon) }\end{array}$ & NTA & $\mathrm{CO}$ & 6 & 27.30 & 21.80 & 6 & 34.00 & 5.09 & \\
\hline wam01 & Balicasag & NTA & $\mathrm{CO}$ & 7 & 54.79 & 4.18 & 3 & 56.70 & 2.12 & $\mathrm{~B}$ \\
\hline wam01 & Balicasag & NTA & $\mathrm{CO}$ & 5 & 44.84 & 3.67 & 5 & 54.07 & 3.19 & A \\
\hline $\begin{array}{l}\text { raymundo0 } \\
8 \\
\end{array}$ & Balicasag & NTA & $\mathrm{CO}$ & 3 & 66.17 & 12.93 & 3 & 73.13 & 13.79 & \\
\hline
\end{tabular}

品 


\begin{tabular}{|c|c|c|c|c|c|c|c|c|c|c|}
\hline $\begin{array}{l}\text { raymundo0 } \\
8\end{array}$ & Basdiot & NTA & $\mathrm{CO}$ & 3 & 65.17 & 2.59 & 3 & 75.12 & 8.62 & \\
\hline $\begin{array}{l}\text { raymundo0 } \\
8\end{array}$ & Bil-isan & NTA & $\mathrm{CO}$ & 3 & 52.74 & 10.34 & 3 & 68.16 & 8.62 & \\
\hline pittman08 & BIRNM & NTA & $\mathrm{S}$ & 80 & 13.78 & 5.90 & 95 & 14.91 & 5.75 & \\
\hline jennings95 & Cousin & NTA & $\mathrm{P}$ & 15 & 0.55 & 0.33 & 3 & 2.04 & 0.87 & \\
\hline white10 & $\begin{array}{l}\text { Daanlung } \\
\text { sod- } \\
\text { Guiwang }\end{array}$ & NTA & $\mathrm{CO}$ & 6 & 30.20 & 15.19 & 6 & 45.30 & 5.71 & \\
\hline White10 & Gawi & NTA & $\mathrm{CO}$ & 6 & & & 6 & & & $B$ \\
\hline White10 & Gawi & NTA & $\mathrm{CO}$ & 6 & 31.80 & 12.00 & 6 & 32.80 & 16.41 & $A$ \\
\hline $\begin{array}{l}\text { raymundo0 } \\
8\end{array}$ & $\begin{array}{l}\text { Gilutunga } \\
\mathrm{n}\end{array}$ & NTA & & 3 & 71.14 & 12.06 & 3 & 70.65 & 12.06 & \\
\hline white10 & $\begin{array}{l}\text { Granada( } \\
\text { Boljoon) }\end{array}$ & NTA & $\mathrm{CO}$ & 6 & 43.50 & 6.12 & 6 & 31.60 & 14.08 & \\
\hline $\begin{array}{l}\text { friedlander0 } \\
6\end{array}$ & Hanauma & NTA & $\mathrm{S}$ & 4 & 6.60 & 1.03 & 3 & 13.68 & 1.25 & \\
\hline $\begin{array}{l}\text { friedlander1 } \\
0\end{array}$ & Hanauma & NTA & $\mathrm{S}$ & 3 & 7.26 & 5.28 & 2 & 16.95 & 2.30 & \\
\hline grigg94 & Hanauma & NTA & $\mathrm{S}$ & 10 & 46.30 & 2.10 & 10 & 48.30 & 2.51 & \\
\hline $\begin{array}{l}\text { tkachenko1 } \\
0\end{array}$ & $\begin{array}{l}\text { hobihu(na } \\
\text { nwan) }\end{array}$ & NTA & $\mathrm{CO}$ & 1 & 60.00 & & 3 & 27.33 & 7.63 & \\
\hline $\begin{array}{l}\text { svensson0 } \\
9\end{array}$ & $\begin{array}{l}\text { hon ong } \\
\text { WIB }\end{array}$ & NTA & $\mathrm{P}$ & 2 & 23.47 & 2.54 & 8 & 54.89 & & \\
\hline $\begin{array}{l}\text { svensson0 } \\
9\end{array}$ & $\begin{array}{l}\text { hon ong } \\
\text { WIBP }\end{array}$ & NTA & $\mathrm{P}$ & 2 & 16.36 & 2.41 & 8 & 18.36 & 7.05 & $B$ \\
\hline $\begin{array}{l}\text { svensson0 } \\
9\end{array}$ & $\begin{array}{l}\text { hon ong } \\
\text { WIBP }\end{array}$ & NTA & $\mathrm{P}$ & 2 & 23.47 & 2.54 & 8 & 24.53 & & A \\
\hline $\begin{array}{l}\text { friedlander0 } \\
6\end{array}$ & Honolua & NTA & $\mathrm{S}$ & 4 & 11.36 & 1.42 & 3 & 17.49 & 1.45 & \\
\hline $\begin{array}{l}\text { friedlander1 } \\
0\end{array}$ & Honolua & NTA & $\mathrm{S}$ & 3 & 10.18 & 4.71 & 2 & 17.30 & 0.44 & \\
\hline grigg94 & Honolua & NTA & $\mathrm{S}$ & 10 & 40.70 & 5.80 & 10 & 49.70 & 5.50 & \\
\hline
\end{tabular}

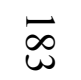




\begin{tabular}{|c|c|c|c|c|c|c|c|c|c|c|}
\hline $\begin{array}{l}\text { friedlander0 } \\
6\end{array}$ & $\begin{array}{l}\text { Kaneohe } \\
\text { Bay }\end{array}$ & NTA & $S$ & 4 & 7.87 & 0.95 & 2 & 12.40 & 0.94 & \\
\hline Mcc06 & Kisite & NTA & $\mathrm{S}$ & & & & & 47.40 & & \\
\hline chateau05 & laregnere & NTA & $S$ & 2 & 23.85 & 1.13 & 12 & 29.01 & 4.64 & \\
\hline $\begin{array}{l}\text { letourneur9 } \\
6 \\
\end{array}$ & longogori & NTA & $\mathrm{S}$ & 3 & 65.80 & & 3 & 66.20 & & \\
\hline $\begin{array}{l}\text { hernandezd } \\
\text { elgado07 }\end{array}$ & $\begin{array}{l}\text { Luis Pena } \\
\text { Channel }\end{array}$ & NTA & $S$ & 2 & 19.00 & 2.83 & 2 & 17.00 & 1.41 & $\mathrm{~B}$ \\
\hline $\begin{array}{l}\text { hernandezd } \\
\text { elgado07 }\end{array}$ & $\begin{array}{l}\text { Luis Pena } \\
\text { Channel }\end{array}$ & NTA & $S$ & 2 & 30.50 & 0.71 & 2 & 24.00 & & A \\
\hline $\begin{array}{l}\text { raymundo0 } \\
8\end{array}$ & Maayong & NTA & & 3 & 32.84 & 28.44 & 3 & 77.11 & 17.23 & \\
\hline goetze11 & namena & NTA & $\mathrm{C}$ & 2 & 37.87 & 1.39 & 2 & 41.48 & 1.65 & \\
\hline goetze11 & namuri & NTA & $\mathrm{C}$ & 2 & 37.67 & 1.07 & 2 & 37.09 & 1.41 & \\
\hline page09 & Palau & NTA & & & 3.45 & & & 4.10 & & \\
\hline wam01 & Pamilican & NTA & $\mathrm{C}$ & 11 & 40.43 & 6.80 & 3 & 47.99 & 4.83 & $B$ \\
\hline wam01 & Pamilican & NTA & $\mathrm{C}$ & 1 & 33.91 & & 3 & 45.75 & 3.22 & $\mathrm{~A}$ \\
\hline nemeth05 & $\begin{array}{l}\text { red hind } \\
\text { bank }\end{array}$ & NTA & $S$ & 48 & 29.90 & & 49 & 31.10 & & \\
\hline $\begin{array}{l}\text { raymundo0 } \\
8\end{array}$ & Saavedra & NTA & & 3 & 69.65 & 4.31 & 3 & 73.63 & 11.20 & \\
\hline christie03 & $\begin{array}{l}\text { San } \\
\text { Salvador }\end{array}$ & NTA & $\mathrm{CO}$ & & 126.00 & & & 138.00 & & \\
\hline hawkins06 & soufriere & NTA & $S$ & 83 & 25.56 & 3.15 & 114 & 26.59 & 3.69 & $B$ \\
\hline hawkins06 & soufriere & NTA & $S$ & 83 & 30.36 & 3.94 & 114 & 31.61 & 4.62 & $A$ \\
\hline wam01 & Sumilon & NTA & $\mathrm{CO}$ & 2 & 54.84 & 0.65 & 2 & 47.10 & 0.72 & \\
\hline russ89 & Sumilon & NTA & $\mathrm{CO}$ & 6 & 36.31 & 4.08 & 6 & 48.30 & 4.78 & \\
\hline russ89 & Sumilon & NTA & $\mathrm{CO}$ & 6 & 35.07 & 2.18 & 6 & 36.31 & 4.08 & A \\
\hline russ89 & Sumilon & NTA & $\mathrm{CO}$ & 6 & 40.15 & 7.33 & 6 & 48.30 & 4.78 & $B$ \\
\hline
\end{tabular}




\begin{tabular}{|c|c|c|c|c|c|c|c|c|c|c|}
\hline wantiez96 & $\begin{array}{l}\text { SW New } \\
\text { Caledoni } \\
\text { a } \\
\text { (Noumea) }\end{array}$ & NTA & $\mathrm{S}$ & 6 & 29.83 & 19.79 & 5 & 32.87 & 5.38 & $\mathrm{~B}$ \\
\hline wantiez96 & $\begin{array}{l}\text { SW New } \\
\text { Caledoni } \\
\text { a } \\
\text { (Noumea) }\end{array}$ & NTA & $S$ & 6 & 31.67 & 15.14 & 5 & 51.40 & 6.37 & A \\
\hline $\begin{array}{l}\text { raymundo0 } \\
8\end{array}$ & Talima & NTA & & 3 & 48.76 & 2.59 & 3 & 73.13 & 13.79 & \\
\hline $\begin{array}{l}\text { raymundo0 } \\
8\end{array}$ & Tawala & NTA & & 3 & 62.19 & 10.34 & 3 & 60.20 & 6.89 & \\
\hline $\begin{array}{l}\text { friedlander0 } \\
6\end{array}$ & Waikiki & NTA & & 4 & 8.41 & 1.07 & 2 & 10.97 & 2.00 & \\
\hline $\begin{array}{l}\text { friedlander0 } \\
6\end{array}$ & WaiOpae & NTA & & 2 & 13.82 & 0.96 & 2 & 14.29 & 0.87 & \\
\hline $\begin{array}{l}\text { raymundo0 } \\
8\end{array}$ & Zaragosa & NTA & & 3 & 41.29 & 32.75 & 3 & 76.12 & 11.20 & \\
\hline cinner06 & $\begin{array}{l}\text { Kakarota } \\
\mathrm{n}\end{array}$ & $P$ & C & 3 & 87.30 & 9.01 & 3 & 82.30 & 6.55 & \\
\hline cinner06 & Muluk & $P$ & C & 5 & 82.20 & 14.53 & 5 & 79.40 & 17.89 & \\
\hline $\begin{array}{l}\text { friedlander0 } \\
6\end{array}$ & Waikiki & $\mathrm{P}$ & & 4 & 8.41 & 1.07 & 2 & 10.23 & 1.84 & \\
\hline $\begin{array}{l}\text { friedlander0 } \\
6\end{array}$ & $\begin{array}{l}\text { Kealakek } \\
\text { ua }\end{array}$ & & $\mathrm{S}$ & 13 & 20.47 & 3.15 & 29 & 19.68 & 5.23 & \\
\hline $\begin{array}{l}\text { friedlander1 } \\
0\end{array}$ & $\begin{array}{l}\text { Kealakek } \\
\text { ua }\end{array}$ & & $\mathrm{S}$ & 13 & 21.58 & & 29 & 18.97 & & \\
\hline $\begin{array}{l}\text { friedlander0 } \\
6\end{array}$ & Old Kona & & & 2 & 23.47 & 1.16 & 3 & 14.77 & 1.46 & \\
\hline White10 & Pasil & NTA & & 6 & 21.70 & 18.13 & 6 & 46.20 & 17.64 & \\
\hline russ11 & Sumilon & & & 6 & & & 6 & & & \\
\hline russ11 & Sumilon & & & 6 & & & 6 & & & \\
\hline White10 & Sumilon & & & & & & & & & \\
\hline roberts92 & Sinai & $P$ & $\mathrm{~S}$ & & 47.80 & & & 44.20 & & \\
\hline
\end{tabular}

\section{$\underset{\infty}{\infty}$}


Table A.9. Raw data and natural log of response ratios by case for coral richness.

\begin{tabular}{|c|c|c|c|c|c|c|c|c|c|c|c|c|c|c|c|c|}
\hline $\begin{array}{l}\text { 1st } \\
\text { author } \\
\text { /year }\end{array}$ & Case & $\begin{array}{l}\text { Te } \\
\text { chn } \\
\text { iqu } \\
\mathrm{e} \\
\end{array}$ & $\begin{array}{l}\text { Act } \\
\text { or } \\
\text { gro } \\
\text { up }\end{array}$ & $\begin{array}{l}\mathrm{Re} \\
\text { gio } \\
\mathrm{n}\end{array}$ & $\begin{array}{l}\text { Stu } \\
\text { dy } \\
\text { typ } \\
\text { e } \\
\end{array}$ & $\begin{array}{l}\text { Num } \\
\text { ber } \\
\text { of } \\
\text { speci } \\
\text { es }\end{array}$ & $\begin{array}{l}\text { Mgmt } \\
\text { area } \\
\left(\mathrm{km}^{\wedge} 2\right)\end{array}$ & $\begin{array}{l}\text { Year } \\
\mathrm{s} \\
\text { mana } \\
\text { ged }\end{array}$ & $\begin{array}{l}\text { con } \\
\text { trol } \\
\mathrm{n}\end{array}$ & $\begin{array}{l}\text { contr } \\
\text { ol } \\
\text { mean }\end{array}$ & $\begin{array}{l}\text { con } \\
\text { trol } \\
\text { SD } \\
\end{array}$ & $\begin{array}{l}\text { treat } \\
\text { ment } \\
\mathrm{n}\end{array}$ & $\begin{array}{l}\text { treat } \\
\text { ment } \\
\text { mean }\end{array}$ & $\begin{array}{l}\text { treat } \\
\text { ment } \\
\text { SD }\end{array}$ & InR & $\begin{array}{l}\mathrm{BACl} \\
: \mathrm{B} / \mathrm{A}\end{array}$ \\
\hline $\begin{array}{l}\text { Ardiwijay } \\
\text { a06 }\end{array}$ & $\begin{array}{l}\text { Anoi } \\
\text { Itam }\end{array}$ & G & C & IP & $S$ & 45 & 1.2055 & & 6 & $\begin{array}{r}4.428 \\
9 \\
\end{array}$ & $\begin{array}{r}2.0 \\
7 \\
\end{array}$ & 6 & 4.58 & 1.68 & & \\
\hline $\begin{array}{l}\text { Ardiwijay } \\
\text { a06 }\end{array}$ & $\begin{array}{l}\text { Anoi } \\
\text { Itam }\end{array}$ & $G$ & C & IP & $S$ & 45 & 1.2055 & & 6 & $\begin{array}{r}10.86 \\
7\end{array}$ & $\begin{array}{r}5.2 \\
63\end{array}$ & 6 & 11.99 & 2.79 & 0.10 & \\
\hline $\begin{array}{l}\text { fonesca0 } \\
6\end{array}$ & $\begin{array}{l}\text { DTN } \\
\mathrm{P}\end{array}$ & $\mathrm{G}$ & $S$ & $\mathrm{CA}$ & $S$ & 6 & & 10 & & $\begin{array}{r}4.347 \\
9 \\
\end{array}$ & & & 4.49 & & 0.03 & \\
\hline $\begin{array}{l}\text { Ardiwijay } \\
\text { a06 }\end{array}$ & $\begin{array}{l}\text { le } \\
\text { Meul } \\
\text { ee }\end{array}$ & G & C & IP & $S$ & 45 & 1.779 & & 6 & $\begin{array}{r}4.428 \\
9\end{array}$ & $\begin{array}{r}2.0 \\
7\end{array}$ & 4 & 5.01 & 1.67 & & \\
\hline $\begin{array}{l}\text { Ardiwijay } \\
\text { a06 }\end{array}$ & $\begin{array}{l}\text { le } \\
\text { Meul } \\
\text { ee }\end{array}$ & G & C & IP & $S$ & 45 & 1.779 & & 6 & $\begin{array}{r}10.86 \\
7 \\
\end{array}$ & $\begin{array}{r}5.2 \\
63 \\
\end{array}$ & 4 & 12.68 & 3.39 & 0.15 & \\
\hline $\begin{array}{l}\text { Ardiwijay } \\
\text { a06 }\end{array}$ & $\begin{array}{l}\text { Kawa } \\
\text { san } \\
\text { Wisat } \\
\text { a }\end{array}$ & G & $\mathrm{CO}$ & IP & $S$ & 45 & 2.07 & 8 & 6 & $\begin{array}{r}4.428 \\
9 \\
\end{array}$ & $\begin{array}{r}2.0 \\
7 \\
\end{array}$ & 8 & 5.02 & 1.76 & & \\
\hline $\begin{array}{l}\text { Ardiwijay } \\
\text { a06 }\end{array}$ & $\begin{array}{l}\text { Kawa } \\
\text { san } \\
\text { Wisat } \\
\text { a }\end{array}$ & G & $\mathrm{CO}$ & IP & $S$ & 45 & 2.07 & 8 & 6 & $\begin{array}{r}10.86 \\
7 \\
\end{array}$ & $\begin{array}{r}5.2 \\
63\end{array}$ & 8 & 14.56 & 6.17 & 0.29 & \\
\hline grigg94 & $\begin{array}{l}\text { Keal } \\
\text { akak } \\
\text { uaML } \\
\text { CD }\end{array}$ & G & $S$ & IP & $S$ & 5 & 1.24 & 23 & 10 & 4 & 1.4 & 10 & 6.66 & 1.15 & 0.21 & \\
\hline $\begin{array}{l}\text { friedlande } \\
\text { r10 }\end{array}$ & $\begin{array}{l}\text { Keal } \\
\text { akek }\end{array}$ & G & $S$ & IP & $S$ & 5 & 1.24 & 38 & 13 & 6.15 & $\begin{array}{l}1.9 \\
83\end{array}$ & 22 & 4.95 & 1.13 & & \\
\hline
\end{tabular}




\begin{tabular}{|c|c|c|c|c|c|c|c|c|c|c|c|c|c|c|c|c|}
\hline & ua & & & & & & & & & & & & & & & \\
\hline grigg94 & $\begin{array}{l}\text { Mane } \\
\text { le }\end{array}$ & G & S & IP & S & & 1.1169 & 16 & 10 & 5 & $\begin{array}{r}1.1 \\
4\end{array}$ & 10 & 5.66 & 0.58 & 0.12 & \\
\hline grigg94 & $\begin{array}{l}\text { Molo } \\
\text { kini }\end{array}$ & G & $S$ & IP & $S$ & & 0.3561 & 15 & 10 & 5.33 & $\begin{array}{r}1.1 \\
5\end{array}$ & 10 & 6.00 & 0.00 & 0.12 & \\
\hline dung09 & $\begin{array}{l}\text { NhaT } \\
\text { rang }\end{array}$ & $G$ & $S$ & IP & $\mathrm{T}$ & 312 & & 3 & 3 & 145 & $\begin{array}{r}36 . \\
43 \\
\end{array}$ & 3 & $\begin{array}{r}138.3 \\
3 \\
\end{array}$ & 43.02 & -0.05 & \\
\hline $\begin{array}{l}\text { Ardiwijay } \\
\text { a06 }\end{array}$ & $\begin{array}{l}\text { Pang } \\
\text { lima } \\
\text { Laut }\end{array}$ & $\mathrm{G}$ & C & IP & $S$ & 45 & 2.06 & 8 & 6 & $\begin{array}{r}4.428 \\
9 \\
\end{array}$ & $\begin{array}{r}2.0 \\
7 \\
\end{array}$ & 6 & 4.21 & 2.11 & & \\
\hline $\begin{array}{l}\text { Ardiwijay } \\
\text { a06 }\end{array}$ & $\begin{array}{l}\text { Pang } \\
\text { lima } \\
\text { Laut }\end{array}$ & $G$ & C & IP & $S$ & 45 & 2.06 & 8 & 6 & $\begin{array}{r}10.86 \\
7\end{array}$ & $\begin{array}{r}5.2 \\
63\end{array}$ & 6 & 9.57 & 5.74 & -0.13 & \\
\hline $\begin{array}{l}\text { friedlande } \\
\text { r10 }\end{array}$ & $\begin{array}{l}\text { Pupu } \\
\text { kea }\end{array}$ & G & $S$ & IP & $S$ & 5 & 0.71 & 4 & 2 & $\begin{array}{r}3.036 \\
7\end{array}$ & $\begin{array}{r}0.5 \\
8\end{array}$ & 2 & 4.00 & 0.50 & 0.28 & \\
\hline $\begin{array}{l}\text { Cros\&Mc } \\
\text { C03 }\end{array}$ & $\begin{array}{l}\text { Ras } \\
\text { Iwati } \\
\text { ne }\end{array}$ & G & $\mathrm{S}$ & $\begin{array}{l}\text { WI } \\
O\end{array}$ & & & & 2 & 9 & 0.81 & & 12 & 0.80 & & -0.01 & \\
\hline Mcc06 & $\begin{array}{l}\text { Tang } \\
\text { a }\end{array}$ & G & C & $\begin{array}{l}\text { WI } \\
O\end{array}$ & $S$ & 27 & 5.75 & 9 & 7 & 11.3 & $\begin{array}{r}3.1 \\
75\end{array}$ & 4 & 13.30 & 5.20 & 0.16 & \\
\hline zvuloni10 & $\begin{array}{l}\text { chum } \\
\text { be }\end{array}$ & $\begin{array}{l}\text { NT } \\
\text { A }\end{array}$ & $P$ & $\begin{array}{l}\text { WI } \\
\mathrm{O}\end{array}$ & $S$ & 30 & & 14 & 2 & $\begin{array}{r}13.20 \\
7\end{array}$ & $\begin{array}{r}3.8 \\
92\end{array}$ & 2 & 30.19 & 1.34 & 0.83 & \\
\hline $\begin{array}{l}\text { friedlande } \\
\text { r10 }\end{array}$ & $\begin{array}{l}\text { Hana } \\
\text { uma }\end{array}$ & $\begin{array}{l}\text { NT } \\
\text { A }\end{array}$ & $S$ & IP & $S$ & 5 & 0.41 & 40 & 3 & $\begin{array}{r}2.375 \\
4\end{array}$ & $\begin{array}{r}0.5 \\
21\end{array}$ & 2 & 4.37 & 0.38 & 0.24 & \\
\hline grigg94 & $\begin{array}{l}\text { Hana } \\
\text { uma }\end{array}$ & $\begin{array}{l}\text { NT } \\
\text { A }\end{array}$ & $S$ & IP & $S$ & 5 & 0.41 & 25 & 10 & 4.66 & $\begin{array}{r}1.1 \\
5\end{array}$ & 10 & 3.33 & 0.58 & & \\
\hline $\begin{array}{l}\text { friedlande } \\
\text { r10 }\end{array}$ & $\begin{array}{l}\text { Hono } \\
\text { lua }\end{array}$ & $\begin{array}{l}\text { NT } \\
\text { A }\end{array}$ & $S$ & IP & $\mathrm{s}$ & 5 & 0.19 & 29 & 3 & $\begin{array}{r}2.792 \\
3\end{array}$ & $\begin{array}{r}0.3 \\
94\end{array}$ & 2 & 5.00 & 0.55 & 0.39 & \\
\hline grigg94 & $\begin{array}{l}\text { Hono } \\
\text { lua }\end{array}$ & $\begin{array}{l}\text { NT } \\
\text { A }\end{array}$ & $\mathrm{S}$ & IP & $\mathrm{s}$ & 5 & 0.19 & 14 & 10 & 5 & $\begin{array}{r}1.4 \\
1\end{array}$ & 10 & 5.87 & 1.13 & & \\
\hline Mcc06 & Kisite & NT & $\mathrm{S}$ & WI & $\mathrm{S}$ & 32 & 10 & 31 & 7 & 11.3 & 3.1 & 3 & 12.70 & 1.21 & 0.12 & \\
\hline
\end{tabular}




\begin{tabular}{|c|c|c|c|c|c|c|c|c|c|c|c|c|c|c|c|c|}
\hline & & A & & $\mathrm{O}$ & & & & & & & 75 & & & & & \\
\hline zvuloni10 & $\begin{array}{l}\text { mne } \\
\text { mba } \\
\text { (zanz } \\
\text { ibar) }\end{array}$ & $\begin{array}{l}\text { NT } \\
\text { A }\end{array}$ & & $\begin{array}{l}\text { WI } \\
\text { O }\end{array}$ & S & 30 & & 17 & 2 & $\begin{array}{r}13.20 \\
7 \\
\end{array}$ & $\begin{array}{r}3.8 \\
92\end{array}$ & 2 & 23.72 & 1.54 & 0.59 & \\
\hline $\begin{array}{l}\text { Cros\&Mc } \\
\text { C03 }\end{array}$ & $\begin{array}{l}\text { Mom } \\
\text { basa } \\
\text { MNP }\end{array}$ & $\begin{array}{l}\text { NT } \\
\mathrm{A}\end{array}$ & $\mathrm{S}$ & $\begin{array}{l}\text { WI } \\
\mathrm{O}\end{array}$ & $\mathrm{S}$ & & & 12 & 9 & 0.81 & & 18 & 0.70 & & -0.15 & \\
\hline dung09 & $\begin{array}{l}\text { NhaT } \\
\text { rang }\end{array}$ & $\begin{array}{l}\text { NT } \\
\text { A }\end{array}$ & $S$ & IP & $\mathrm{T}$ & 312 & & 3 & & 155 & & & $\begin{array}{r}156.0 \\
0 \\
\end{array}$ & & 0.01 & \\
\hline white84 & $\begin{array}{l}\text { Sumil } \\
\text { on }\end{array}$ & $\begin{array}{l}\text { NT } \\
\mathrm{A}\end{array}$ & $\mathrm{CO}$ & IP & RT & 32 & & 8 & & 27.7 & & & 32.00 & & 0.14 & \\
\hline $\begin{array}{l}\text { fonesca0 } \\
6\end{array}$ & TER & $\begin{array}{l}\text { NT } \\
\mathrm{A}\end{array}$ & S & CA & S & 6 & & 1 & & $\begin{array}{r}1.987 \\
2 \\
\end{array}$ & & & 3.89 & & -0.28 & B \\
\hline $\begin{array}{l}\text { fonesca0 } \\
6\end{array}$ & TER & $\begin{array}{l}\text { NT } \\
\mathrm{A}\end{array}$ & $S$ & $\mathrm{CA}$ & S & 6 & & 1 & & $\begin{array}{r}4.347 \\
9 \\
\end{array}$ & & & 6.41 & & & A \\
\hline cinner06 & $\begin{array}{l}\text { Kaka } \\
\text { rotan }\end{array}$ & $\mathrm{P}$ & C & IP & $\mathrm{S}$ & 51 & 0.5 & 0 & 3 & 35 & & 3 & 37.00 & & 0.06 & \\
\hline cinner06 & $\begin{array}{l}\text { Mulu } \\
\mathrm{k}\end{array}$ & $\mathrm{P}$ & C & IP & $\mathrm{s}$ & 51 & 0.58 & 60 & 5 & 47 & & 5 & 51.00 & & 0.08 & \\
\hline $\begin{array}{l}\text { friedlande } \\
\text { r10 }\end{array}$ & $\begin{array}{l}\text { Keal } \\
\text { akek } \\
\text { ua }\end{array}$ & & $S$ & IP & $S$ & & & & 13 & 6.15 & $\begin{array}{r}1.9 \\
83\end{array}$ & 29 & 5.00 & 1.51 & -0.21 & \\
\hline page 09 & $\begin{array}{l}\text { Pala } \\
\text { u }\end{array}$ & $\begin{array}{l}\text { NT } \\
\mathrm{A}\end{array}$ & & IP & $S$ & & & & & 9.33 & & & 8.25 & & -0.12 & \\
\hline
\end{tabular}


Table A.10. Raw data and natural log of response ratios by case for Catch Per Unit Effort.

\begin{tabular}{|c|c|c|c|c|c|c|c|c|c|c|c|c|c|}
\hline $\begin{array}{l}1 \text { st } \\
\text { author/year }\end{array}$ & Case & $\begin{array}{l}\text { Techni } \\
\text { que }\end{array}$ & Region & $\begin{array}{l}\text { Stud } \\
\mathrm{y} \\
\text { type }\end{array}$ & $\begin{array}{l}\text { Mgmt } \\
\text { area } \\
\left(\mathrm{km}^{\wedge}\right. \\
2)\end{array}$ & $\begin{array}{l}\text { Year } \\
\mathrm{s} \\
\text { mana } \\
\text { ged }\end{array}$ & $\begin{array}{l}\text { contr } \\
\text { ol } n\end{array}$ & $\begin{array}{l}\text { control } \\
\text { mean }\end{array}$ & $\begin{array}{l}\text { control } \\
\text { SD }\end{array}$ & $\begin{array}{l}\text { treat } \\
\text { ment } \\
n\end{array}$ & $\begin{array}{l}\text { treatment } \\
\text { mean }\end{array}$ & $\begin{array}{l}\text { treatment } \\
\text { SD }\end{array}$ & $\ln R$ \\
\hline $\begin{array}{l}\text { mangi\&mc } \\
\mathrm{C} 03\end{array}$ & Galu & G & WIO & $\mathrm{S}$ & & 20 & 12 & 2.69 & 1.005 & 12 & 2.83 & 0.52 & \\
\hline $\begin{array}{l}\text { mangi\&mc } \\
\mathrm{C} 03\end{array}$ & $\begin{array}{l}\text { Kino } \\
\text { ndo }\end{array}$ & G & WIO & $\mathrm{S}$ & & 1 & 12 & 2.69 & 1.005 & 12 & 2.70 & 0.66 & 0.00 \\
\hline $\begin{array}{l}\text { mangi\&mc } \\
\mathrm{C} 03\end{array}$ & $\begin{array}{l}\text { Mwa } \\
\text { epe }\end{array}$ & G & WIO & $\mathrm{S}$ & & 3 & 12 & 2.69 & 1.005 & 12 & 2.76 & 0.69 & 0.03 \\
\hline russ04 & Apo & G+NTA & IP & $\mathrm{T}$ & & 6 & & 0.81 & 0 & & 1.14 & 0.00 & \\
\hline $\begin{array}{l}\text { mangi\&mc } \\
\mathrm{C} 03\end{array}$ & $\begin{array}{l}\text { Keny } \\
\text { atta }\end{array}$ & $\mathrm{G}+\mathrm{NTA}$ & WIO & $\mathrm{S}$ & & 4 & 12 & 2.69 & 1.005 & 12 & 3.15 & 0.35 & \\
\hline McCetal08 & $\begin{array}{l}\text { Keny } \\
\text { atta }\end{array}$ & $\mathrm{G}+\mathrm{NTA}$ & WIO & $\mathrm{S}$ & & 3 & & 2.5148 & 0 & & 4.10 & 0.00 & \\
\hline $\begin{array}{l}\text { McC\&Mang } \\
\text { i00 }\end{array}$ & $\begin{array}{l}\text { Keny } \\
\text { atta }\end{array}$ & G+NTA & WIO & $\mathrm{S}$ & 3.75 & 3.5 & 173 & 3.5 & 4.6 & 295 & 5.60 & 5.60 & \\
\hline $\begin{array}{l}\text { McC\&Mang } \\
\text { i00 }\end{array}$ & $\begin{array}{l}\text { Keny } \\
\text { atta }\end{array}$ & G+NTA & WIO & $\mathrm{S}$ & 3.75 & 3.5 & 173 & 2.2 & 2.2 & 295 & 3.00 & 1.80 & \\
\hline galal99 & Nabq & G+NTA & WIO & $\mathrm{T}$ & & 2 & 31 & 0.84 & 1.058 & 47 & 1.01 & 1.65 & 0.18 \\
\hline Galal12 & Nabq & $\mathrm{G}+\mathrm{NTA}$ & WIO & $\mathrm{T}$ & & 15 & 7 & 0.44 & 0.23 & 7 & 1.02 & 0.20 & 0.84 \\
\hline $\begin{array}{l}\text { McC\&Kaun } \\
\text { daArara }\end{array}$ & $\begin{array}{l}\text { Keny } \\
\text { attaA }\end{array}$ & NTA & WIO & $\mathrm{T}$ & & 2 & 8 & 367.4 & 346 & 24 & 674.50 & 2493.00 & \\
\hline $\begin{array}{l}\text { McC\&Kaun } \\
\text { daArara }\end{array}$ & $\begin{array}{l}\text { Keny } \\
\text { attaA }\end{array}$ & NTA & WIO & $\mathrm{T}$ & & 2 & 8 & 20.3 & 6.7 & 24 & 67.10 & 69.70 & 1.20 \\
\hline roberts 01 & $\begin{array}{l}\text { Soufr } \\
\text { iere }\end{array}$ & NTA & $\mathrm{CA}$ & $\mathrm{T}$ & & 5 & 2 & 4.1335 & 1.173 & 2 & 6.53 & 0.82 & 0.46 \\
\hline alcala90 & $\begin{array}{l}\text { Sumil } \\
\text { on }\end{array}$ & NTA & IP & $\mathrm{T}$ & & 9 & 13 & 0.99 & 0.773 & 12 & 1.98 & 0.55 & 0.69 \\
\hline
\end{tabular}


Notes: $\ln R$ : natural $\log$ of response ratio for case; $v(\operatorname{lnR})$ : variance for case response ratio; $\mathrm{BACI} B / \mathrm{A}$ : indicates if before $(\mathrm{B})$ or after (A) data from a BACI study. 


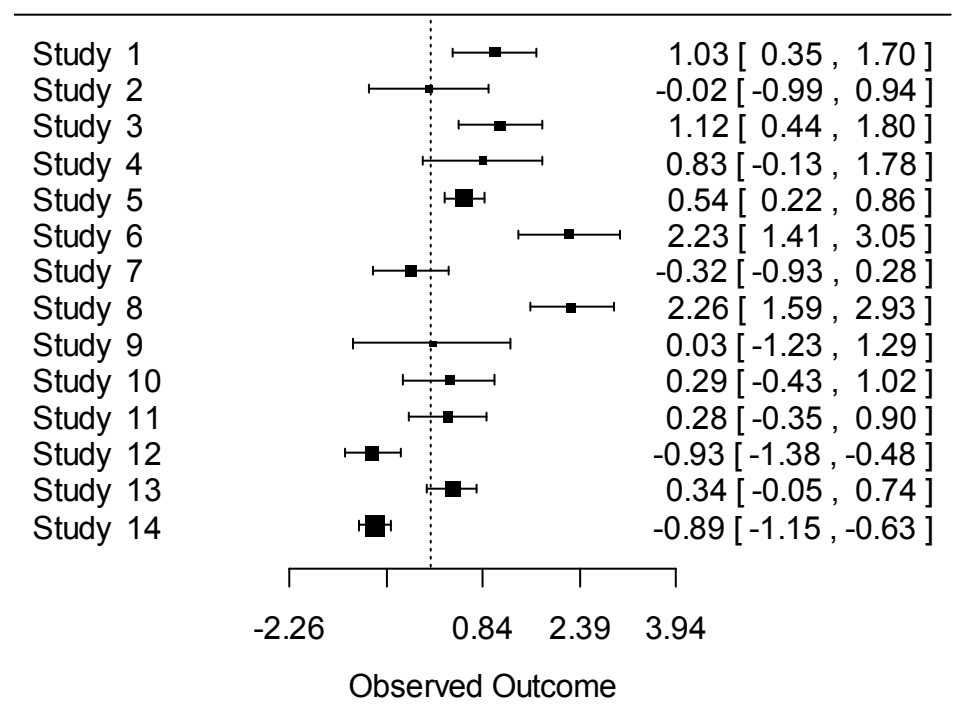

a) 


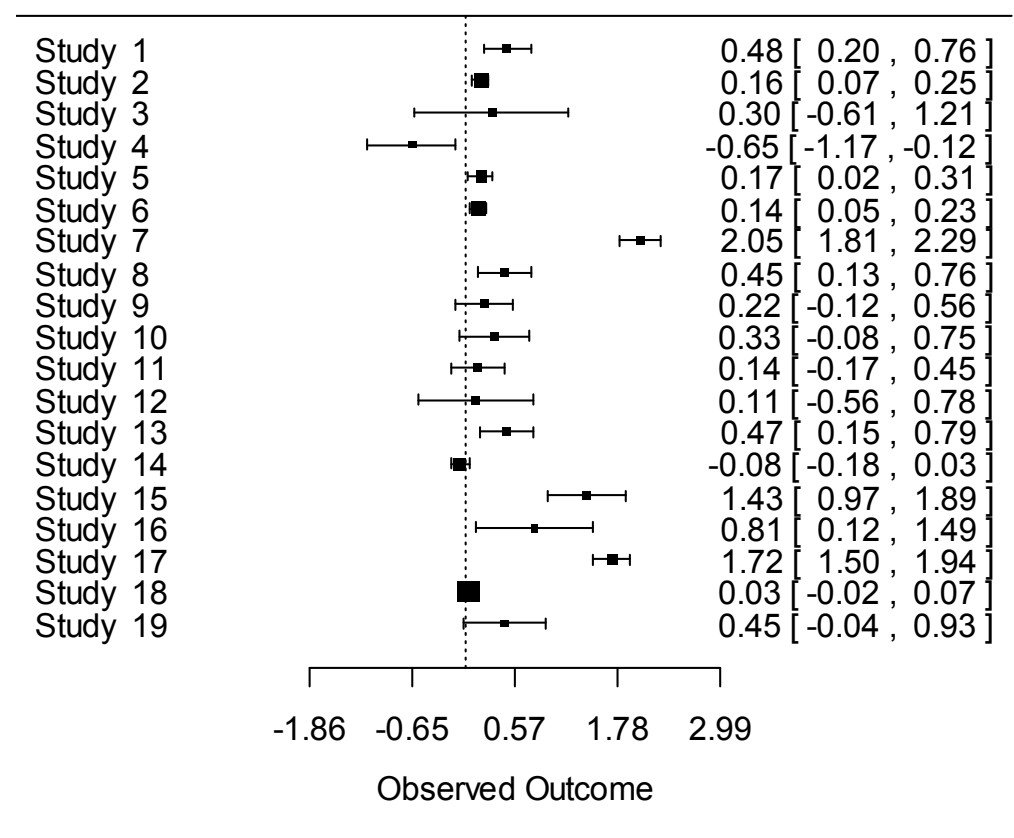




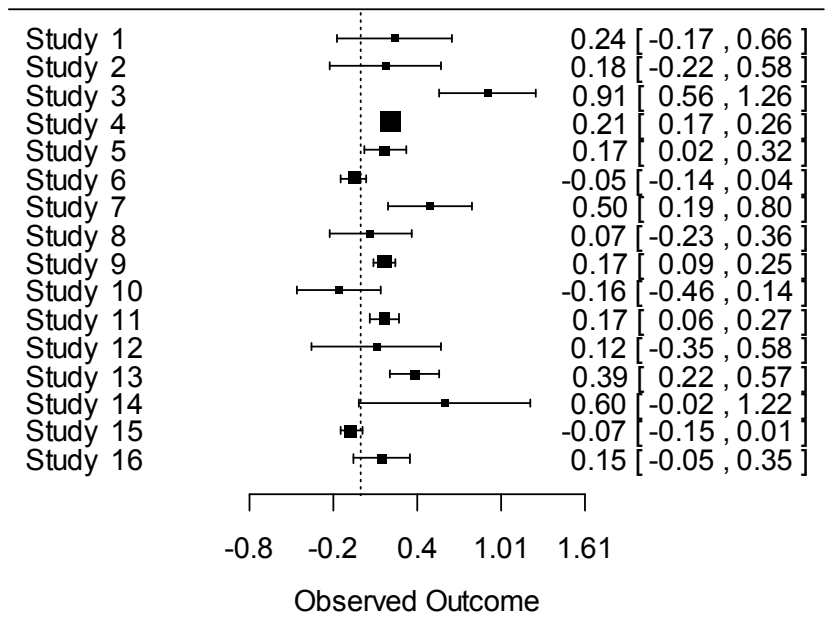

c) 


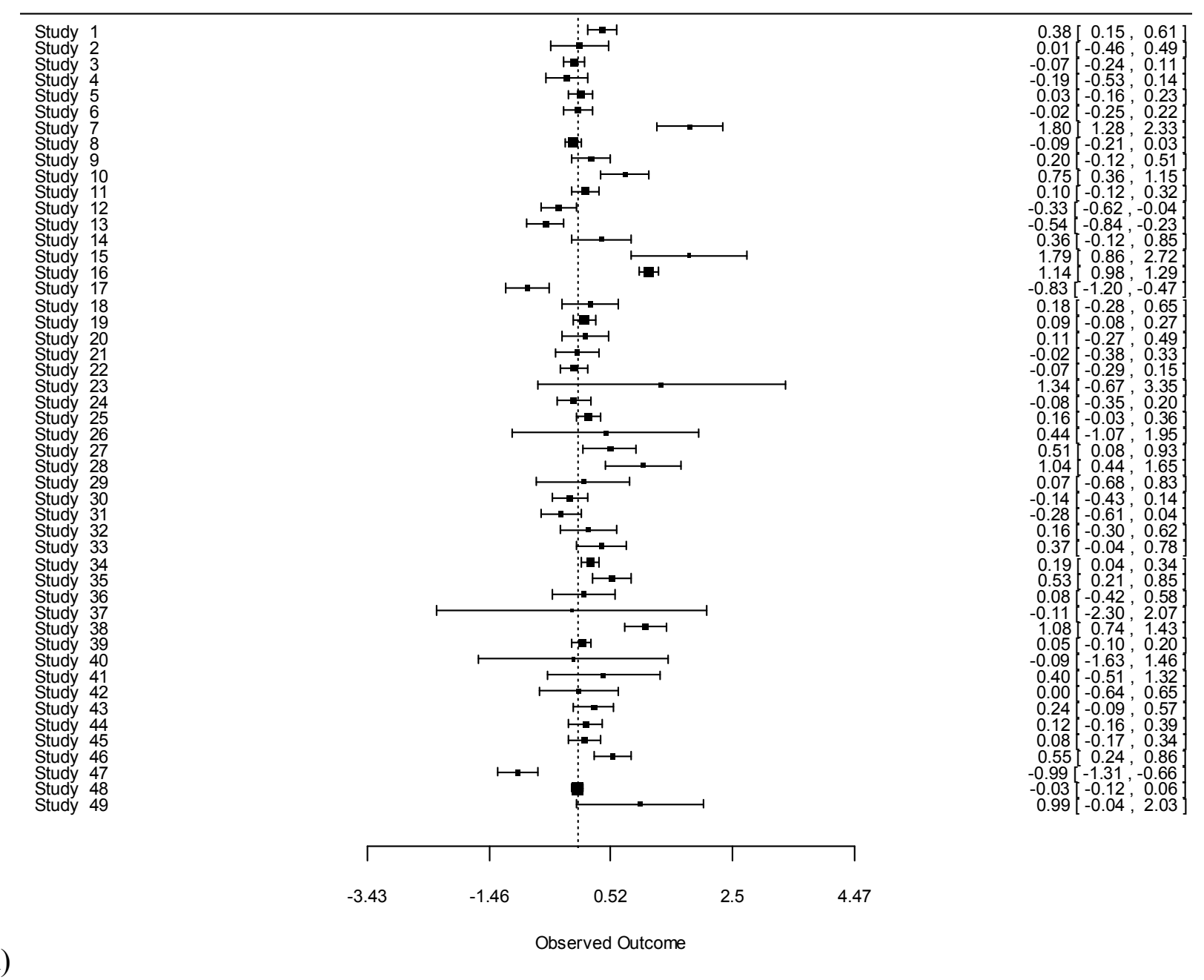

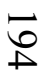




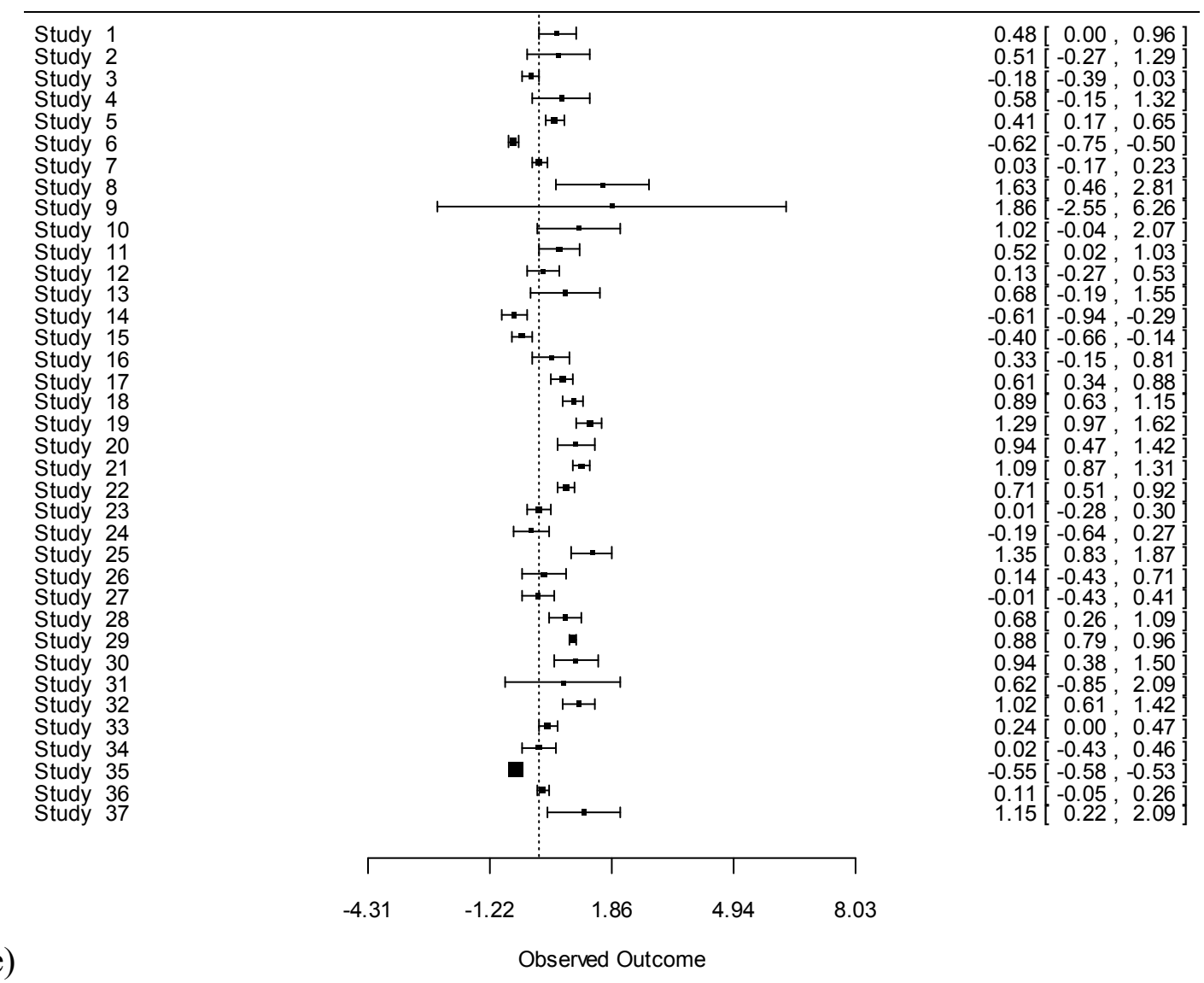




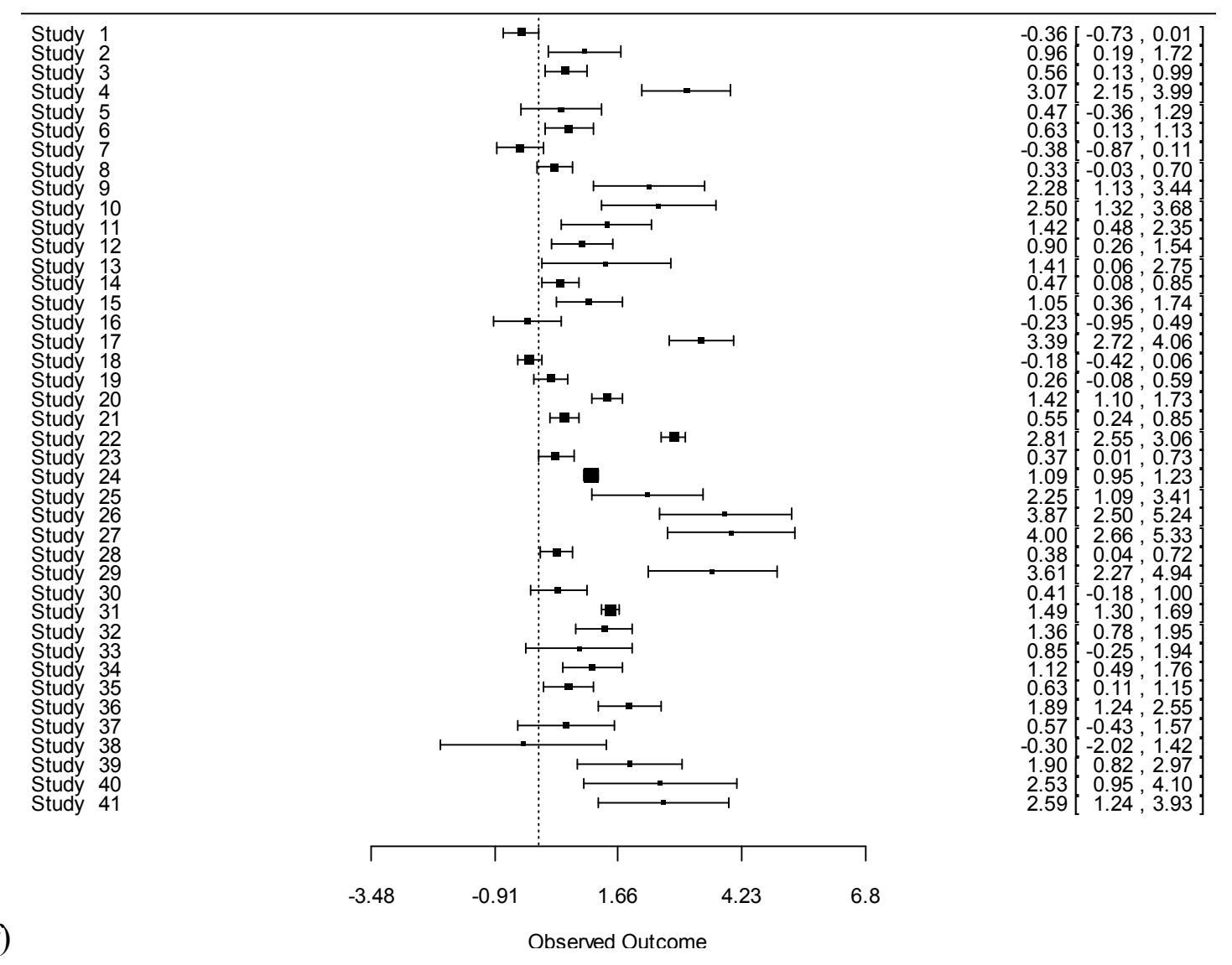

웅 


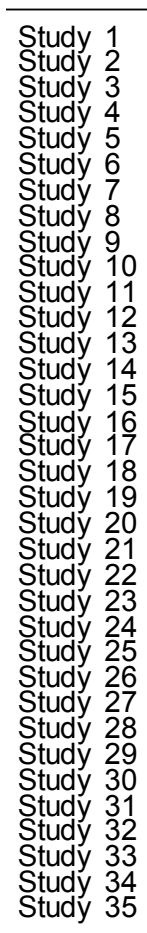

g)

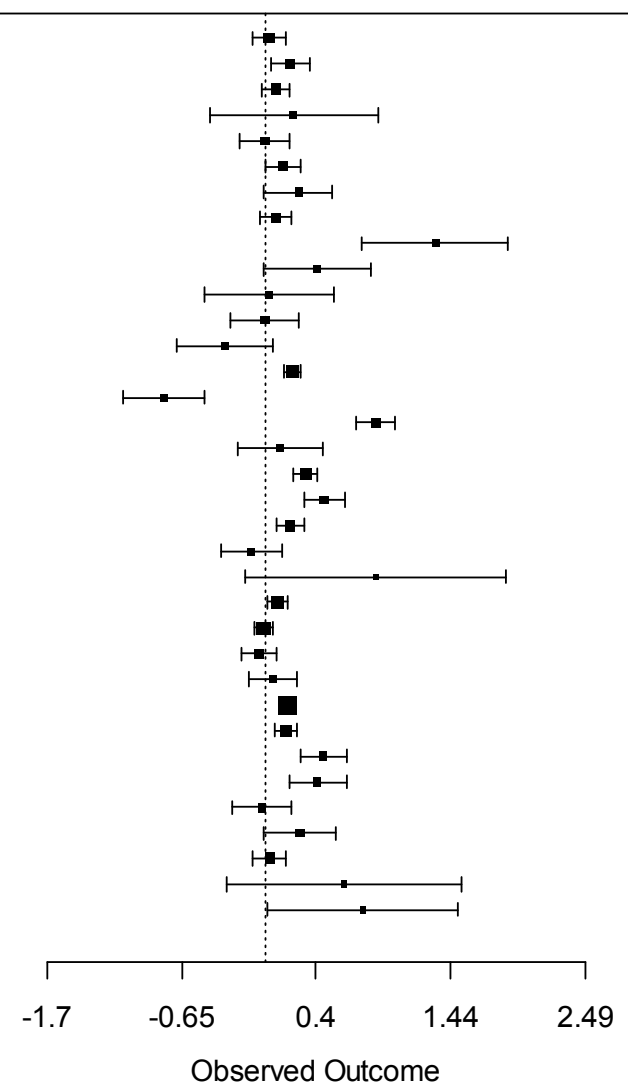

$0.03[-0.10,0.16$ :

$0.08-0.03,0.19$.

$0.00-0.20,0.19$

$0.14[0.00,0.28$.

$0.26-0.01,0.52$.

$0.08-0.04,0.20$.

$0.41-0.01,0.82$

$-0.01-0.28,0.27$.

$-0.32-0.69,0.05$.

$0.21[0.15,0.28$.

$0.85[0.70,1.00$.

$0.12-0.22,0.45$.

$0.32[0.22,0.41$.

\begin{tabular}{l|ll}
0.45 & 0.30, & 0.61 \\
0.20 & 0.08, & 0.31
\end{tabular} .

$-0.11-0.35,0.13$

$0.09-0.02,0.17$.

$-0.02-0.08,0.05$

$0.06-0.13,0.24$.

$0.170 .14,0.21$.

$0.160 .08,0.24$

$0.45-0.27,0.63$.

$.03-0.26,0.20$

$0.03-0.10,0.16$.

$0.61-0.30,1.52$.

$0.76[0.02,1.49$ 


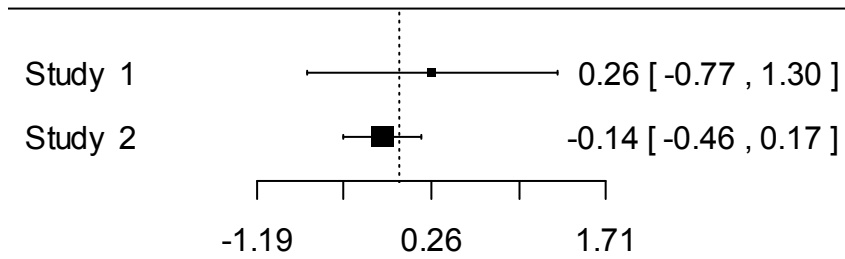

h)

Observed Outcome

\begin{tabular}{|c|c|c|c|}
\hline \multirow{5}{*}{$\begin{array}{l}\text { Study } 1 \\
\text { Study } 2 \\
\text { Study } 3\end{array}$} & & — & $-0.03[-0.39,0.34]$ \\
\hline & & & $0.02[-0.39,0.43]$ \\
\hline & & $\longrightarrow$ & $0.25[0.07,0.43]$ \\
\hline & $\Gamma$ & T & 7 \\
\hline & -0.56 & $0.02 \quad 0.31$ & 0.6 \\
\hline
\end{tabular}

\begin{tabular}{|c|c|c|c|}
\hline \multirow[t]{3}{*}{$\begin{array}{l}\text { Study } 1 \\
\text { Study } 2 \\
\text { Study } 3 \\
\text { Study } 4\end{array}$} & & $\underset{\square}{\square}$ & $\begin{array}{l}0.56[0.25,0.88] \\
0.32[0.11,0.53] \\
0.23[0.03,0.42] \\
0.42[-0.19,1.02]\end{array}$ \\
\hline & $\Gamma$ & 1 & $\square$ \\
\hline & -0.43 & $0.42 \quad 0.84$ & 1.26 \\
\hline
\end{tabular}

j)

$\varpi$ 


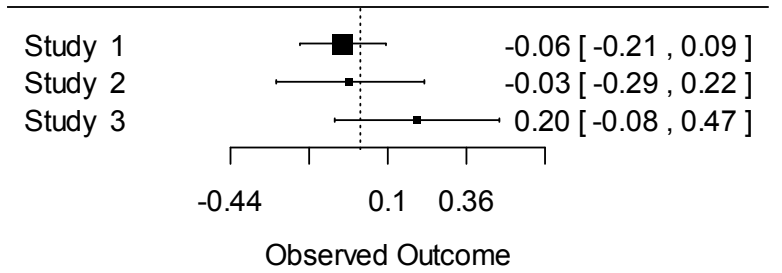

k)

Figure A. Forest plot of effect sizes from each case for a) gear restriction area coral cover, b) gear restriction area fish biomass, c) gear restriction area fish richness, d) no-take area coral cover, e) no-take area fish abundance, f) no-take area fish biomass, g) no-take area fish richness, h) periodic harvest area coral cover, i) periodic harvest area fish abundance, j) periodic harvest area fish biomass, k) periodic harvest area fish richness. 
Appendix B. Interview Questions

Activity Interviews:

\section{Fishing}

1. What methods do you use to fish?

2. Do you fish on the reef or on open water? If both, where do you fish most often?

3. Do you fish in a dugout canoe, fiberglass boat with outboard motor, or on foot?

4. Why do you fish?

5. Is your catch for personal use, for sale, or both?

6. Number of fishers: increasing decreasing no change

7. Is there anyone who is not from your community that participates in fishing in your community? Describe their role.

8. How many kilograms (maximum, minimum, an average) do you catch in a day for the five species caught? What is the price per kilogram for each species caught?

9. Are reef fish and invertebrates more important than similar resources (such as pelagic fish, cattle and goat, or chicken) for meeting your household needs?

10. Are reef fish and invertebrates more important than other income sources (for example, agriculture, livestock, transport, teaching, health, etc.) for meeting your household needs?

11. How much income does one earn in a month through fishing on the reef?

12. Changes in fish stock (numbers, sizes, species composition) and fishery practices, when changes occurred, and why:

13. If one does not fish, does one still consume reef fish or reef invertebrates? 


\section{Coral extraction}

1. Does this activity take place in your community?

2. Why ?

3. How?

4. Is it generally for personal use, for sale, or both ?

5. No. of participants: increase decrease stay the same

6. Is there anyone else from outside your community that participates in this activity in your community? Describe their role in the activity.

7. How much can one person take in a day (maximum, minimum, average amount)? How much does it cost $/ \mathrm{kg}$ ?

8. Is coral more important than other resources (for example for construction, dirt, cement, crushed rock, etc.) to satisfy the needs of your household?

9. Changes in coral extraction :

10. When :

11. Why :

\section{Sand extraction}

1. Does this activity take place in your community?

2. Why ?

3. How?

4. Is it generally for personal use, for sale, or both ?

5. No. of participants : increase decrease stay the same

6. Is there anyone else from outside your community that participates in this activity in 
your community? Describe their role in the activity.

7. How much can one person take in a day (maximum, minimum, average amount)? How much does it cost $/ \mathrm{kg}$ ?

8. Is sand more important than other resources (for example for construction, dirt, cement, crushed rock, etc.) to satisfy the needs of your household?

9. Are any other materials for construction taken from your community? Which and where (rocks, earth, etc.)?

10. Changes in construction and/or sand extraction :

11. When :

12. Why :

Coastal property

1. No. of houses: increase decrease stay the same

2. Changes :

3. When :

4. Why :

5. How much does coastal property cost today?

Transport by speedboat

1. Who participates, what they transport, and where to:

2. Why :

3. No. Of participants: increase decrease stay the same

4. Is there anyone else from outside your community that participates in this activity in your community? Describe their role in the activity. 
5. How much do you earn in one month for transport by speedboat?

\section{Tourism}

1. What jobs related to tourism take place in your community? How are tourists accommodated?

2. What tourist activities take place in your community? :

3. No. of tourists in one week : increase decrease stay the same

4. No. People employed in the tourist industry: increase decrease stay the same

5. Is there anyone else from outside your community that participates in this activity in your community? Describe their role in the activity.

6. How much do you earn each month from tourism?

Agriculture and livestock

1. How :

2. Is irrigation used?

3. Does deforestation take place?

4. Does burning take place?

5. Are chemicals used?

6. Why :

7. No. of participants : increase decrease stay the same

8. Is there anyone else from outside your community that participates in this activity in your community? Describe their role in the activity.

Reef value

1. We have already discussed fishing, coral, and sand extraction. Is there anything else 
the reef provides for your community?

2. What is the current condition of the reef used by your community?

3. If you had the power to change the situation, what would you change? Why?

4. Is there a need to maintain the reef and its resources?

5. What is the most effective way to maintain the reef/manage reef resources?

6. What methods are in use for maintaining the reef/managing the resources?

7. What is the community's role for maintaining the reef/managing reef resources?

8. What do you see as your personal role in maintaining the reef/managing reef resources?

Perceived non-market values

Please indicate your degree of agreement with the following statements using the scale 5 (agree strongly) to 1 (disagree strongly):

1. The reefs are important for protecting land from storm waves.

2. In the long run, fishing would be better if we cleared the coral.

3. Coral reefs are important only if you fish or dive.

4. I want future generations to enjoy coral reefs.

5. Fishing should be restricted in certain areas even in if no one ever fishes in those areas just to allow the fish and coral to grow.

6. We should restrict development in some coastal areas so that future generations will be able to have natural environments.

Management Interviews:

Fishing 
1. Number of dugout canoes utilized by fishers in this community:

2. Number of fibreglass boats with outboard motors utilized by fishers in this community:

3. What fishing methods are used by fishers here? Line Net Tephrosia Dynamite Lamp Diving equipment(including snorkel mask) Trap Basket Sheet Shawl Harpoon gun Insecticide or other chemical poison Other:

4. What regions do fishers in this community most often frequent while fishing?

5. If fishers from outside this community come to this area to fish, where do they come from? Name the villages.

6. What is the name of the organization that manages the fishery? How many fishers in your community belong to this organization?

7. Name the two species most often fished, the number of kilograms fished in an average week, and the maximum number of kilograms fished in a week.

8. Tell us about the rules of fishing. Who decides the rules? Why are rules implemented? How long have the rules been in place? Does everyone agree to the rules? What happens if someone does not agree to the rules (give an example if possible)? Are rules enforced, and if so, how? Is someone watching to be sure fishers follow the rules? What happens if a rule is broken?

9. If you needed help (for example, to send someone to the hospital), who would you ask?

10. Does anything or anyone else influence the fishery or fish stock? What or who 
and how?

11. What did your grandfather fish - which species and how many kilograms? Have the fish stock or fishing practices changed and if so, how? How have you adapted to these changes? Are there any changes (in fish stock or fishing practices) that you wish to see and if so, describe them.

\section{Sand extraction}

1. From where does this community take sand (name the location)?

2. How many truckloads of sand are taken in an average week? How many truckloads are taken during a week with maximum extraction effort?

3. During what season is sand extraction greatest?

4. Is there a season when sand is not extracted (name the season)?

5. Name the organization that manages sand extraction:

6. Is the amount of sand on the beach increasing, decreasing, or no change?

7. Are changes in sand level on the beach seasonal? If so, what season has the greatest sand levels? What season has the lowest sand levels?

8. Why did your community cease sand extraction practices?

9. Tell us all about about the rules of sand extraction. Who decides the rules? Why are rules implemented? How long have the rules been in place? Does everyone agree to the rules? What happens if someone does not agree to the rules (give an example if possible)? Are rules enforced, and if so, how? Is someone watching to be sure everyone follows the rules? What happens if a rule is broken?

10. Tell us the current state of sand levels at the extraction site and how you know 
(amount of sand, periods or areas of high or low sand, and movement and change of sand levels).

11. If you needed help (for example, to send someone to the hospital), who would you ask?

12. Does anything or anyone else influence the state of beach sand or sand extraction practices? What or who and how?

13. Has the state of beach sand or sand extraction changed and if so, how? How have you adapted to these changes?

\section{Coral reef system}

1. Tell us all about the local reef. Who uses it and who manages it?

2. What is the current state of the reef and how do you know?

3. How does your community protect the reef? What do you do, personally, to protect the reef? Does everyone agree to the rules? What happens if someone does not agree to the rules (give an example if possible)? Are rules enforced, and if so, how? Is someone watching to be sure community members follow the rules? What happens if a rule is broken? What is the ideal way to protect the reef? What challenges does your community encounter in protecting the reef? What are the reasons to not protect the reef?

\section{Itsamia}

How does your community conserve the sea turtles?

How long did it take for poaching to diminish?

Does everyone in the community have knowledge of the life history of sea turtles? 
Benefits of sea turtle protection are evident today and therefore one would be motivated to protect turtles, but how did the community become motivated before the benefits of protection became evident?

Do you think other villages could one day be able to protect sea turtles as effectively as your community?

What is Itsamia's history with Moheli Marine Park and did the community ever have disagreements with park staff or officials? 
Appendix C. Human Subjects Approval and

Renewals 


\section{龟 Portland State}

Human Subjects Research Review Committee

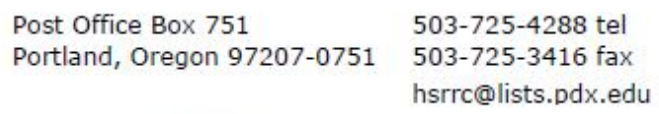

September 29, 2008

To: $\quad$ Sarah Freed

From: Sherril Gelmon, HSRRC Chair

Re: Approval of your application titled, "Coral Reef Health and Resource use in the Comoros Islands" (HSRRC Proposal \# 08568).

Dear Sarah,

In accordance with your request, the Human Subjects Research Review Committee has reviewed your proposal referenced above for compliance with DHHS policies and regulations covering the protection of human subjects. The committee is satisfied that your provisions for protecting the rights and welfare of all subjects participating in the research are adequate, and your project is approved.

Please note the following requirements:

Changes to Protocol: Any changes in the proposed study, whether to procedures, survey instruments, consent forms or cover letters, must be outlined and submitted to the Chair of the HSRRC immediately. The proposed changes cannot be implemented before they have been reviewed and approved by the Committee.

Continuing Review: This approval will expire on 9/29/2009. It is the investigator's responsibility to ensure that a Continuing Review Report (available in ORSP) of the status of the project is submitted to the HSRRC two months before the expiration date, and that approval of the study is kept current.

Adverse Reactions: If any adverse reactions occur as a result of this study, you are required to notify the Chair of the HSRRC immediately. If the problem is serious, approval may be withdrawn pending an investigation by the Committee.

Completion of Study: Please notify the Chair of the Human Subjects Research Review Committee (campus mail code ORSP) as soon as your research has been completed. Study records, including protocols and signed consent forms for each participant, must be kept by the investigator in a secure location for three years following completion of the study.

If you have questions or concerns, please contact the HSRRC in the Office of Research and Sponsored Projects (ORSP), (503) 725-4288, 6th Floor, Unitus Building, 4th \& Lincoln.

\section{Cc: Elise Granek}


Human Subjects Research Review Committee

$\begin{array}{ll}\text { Post Office Box } 751 & 503-725-4288 \text { tel } \\ \text { Portland, Oregon 97207-0751 } & 503-725-3416 \text { fax } \\ & \text { hsrrc@lists.pdx.edu }\end{array}$

September 16, 2009

To: $\quad$ Sarah Freed

From: Nancy Koroloff, HSRRC Chair

Re: $\quad H S R R C$ renewal of approval for your project titled, "Coral Reef Health and Resource use in the Comoros Islands" (HSRRC Proposal \# 08568).

Dear Sarah,

As part of the Committee's continuing review, the Human Subjects Research Review Committee has reviewed your above referenced project for compliance with PSU policy (revised March 2009) and with Department of Health and Human Services policies and regulations on the protection of human subjects.

The Committee is satisfied that your provisions for protecting the rights and welfare of all subjects participating in the research are adequate. Your project is renewed and this approval will expire on September 29, 2010. Please note the following policies:

1. If the project continues beyond the expiration date, the investigator needs to submit a Continuing Review Report form (available in the Office of Research \& Sponsored Projects) two months before the expiration date.

2. If the project is federally funded or initially received a full committee review, the Continuing Review Report form must be reviewed in full committee. The HSRRC no longer performs continuing reviews "in house" for this type of project. To add this project's continuing review to the committee's meeting agenda, please refer to the HSRRC meeting schedule. Submit the report, and the required number of copies, by the submission deadline that is approximately two months before the project's expiration date. The HSRRC needs two months to do a continuing review of the project, so it is extremely important that you meet the committee's submission deadline.

3. If this project finishes before the expiration date, please contact the HSRRC administrator so that the file can be closed and records updated. It is the investigator's responsibility to keep the approval status current. If the project's approval expires while the project is active, the investigator must complete new application and submit it for a new HSRRC review. If federally funded, it must be reviewed in full committee. In addition, any data collected after the expiration date cannot be used in the research. Please don't let this happen!

If you have questions or concerns, please contact the HSRRC in the Office of Research and Sponsored Projects (ORSP), (503) 725-4288, 6th Floor, Unitus Building, 4th \& Lincoln.

Cc: Elise Granek 


\section{蛋 Portland $\underset{U N \text { StVRSITY }}{\text { State }}$}

Post Office Box 751

Portland, Oregon 97207-0751
$503-725-4288$ tel 503-725-3416 fax

hsrrc@lists.pdx.edu

July 2,2010

To: $\quad$ Sarah Freed

From: Nancy Koroloff, HSRRC Chair

Re: $\quad$ HSRRC renewal of approval for your project titled, "Coral Reef Health and Resource use in the Comoros Islands" (HSRRC Proposal \# 08568)

As part of the Committee's continuing review, the Human Subjects Research Review Committee has reviewed your above referenced project for compliance with Department of Health and Human Services policies and regulations on the protection of human subjects.

The Committee is satisfied that your provisions for protecting the rights and welfare of all subjects participating in the research are adequate. Your project is renewed and this approval will expire on 9/29/2011. Please note the following policies:

1. If the project continues beyond the expiration date, the investigator needs to submit a Continuing Review Report form two months before the expiration date. The form is available at www.rsp.pdx.edu/compliance human.php and in the Office of Research \& Sponsored Projects.

2. To add this project's continuing review to the HSRRC/IRB meeting agenda, please refer to the HSRRC/IRB meeting schedule. Submit the report, and the required number of copies, by the submission deadline that is approximately two months before the project's expiration date. The HSRRC/IRB needs two months to do a continuing review of the project, so it is extremely important that you meet the committee's submission deadline.

3. If this project finishes before the expiration date, please contact the HSRRC administrator so that the file can be closed and records updated. It is the investigator's responsibility to keep the approval status current. If the project's approval expires while the project is active, the investigator must complete a new application and submit it for a new HSRRC review. In addition, any data collected after the expiration date cannot be used in the research. Please don't let this happen! 
If you have questions or concerns, please contact the HSRRC in the Office of Research and Sponsored Projects (ORSP), 503-725-4288, Unitus Building, 6th Floor, 4th and Lincoln Streets.

cc: Mark Sytsma 
Human Subjects Research Review Committee

Post Office Box $751 \quad 503-725-4288$ tel

Portland, Oregon 97207-0751 503-725-8170 fax

hsrrc@lists.pdx.edu

October 6, 2011

To:

Sarah Freed

From:

Mary Oschwald, HSRRC Chair

Re: HSRRC renewal of approval for your project titled, "Coral Reef Health and Resource use in the Comoros Islands" (HSRRC Proposal \# 08568).

As part of the Committee's continuing review, the Human Subjects Research Review Committee has reviewed your above referenced project for compliance with PSU and DHHS policies and regulations on the protection of human subjects.

The Committee is satisfied that your provisions for protecting the rights and welfare of all subjects participating in the research are adequate Your project is renewed and this approval will expire on September 29,2012. Please note the following policies:

1. If the project continues beyond the expiration date, the investigator must again submit a Continuing Review Report form two months before the expiration date. The form is available at www.rsp.pdx.edu/compliance_human.php and in the Office of Research \& Strategic Partnerships (RSP).

2. To add this project's continuing review to the HSRRC/IRB meeting agenda, please refer to the HSRRC/IRB meeting schedule. Submit the report, and 8 copies, by the submission deadline that is approximately two months before the project's e expiration date. The HSRRC/IRB needs two months to do a continuing review of the project, so it is extremely important that you meet the committee's submission deadline.

3. If this project finishes before the expiration date, please contact the HSRRC so that the file can be closed and records updated. It is the investigator's responsibility to keep the approval status current. If the project's approval expires while the project is active, the investigator must complete a new application and submit it for a new HSRRC review. In addition, any data collected after the expiration date cannot be used in the research. Please don't let this happen!

If you have questions or concerns, please contact the HSRRC in the Office of Research and Strategic Partnerships (RSP), 503-725-4288, Market Center Building, Room 620.

Cc: Elise Granek 


\section{Portland State University HSRRC Memorandum}

Date: October 4, 2012

To: $\quad$ Sarah Freed

From: Todd Bodner, Chair, HSRRC 2012

Re: HSRRC renewal of approval for your project entitled, "Coral Reef Health and

Resource use in the Comoros Islands" (HSRRC Proposal \#08568)

As part of the Committee's continuing review, the Human Subjects Research Review Committee has reviewed your above referenced project for compliance with Department of Health and Human Services policies and regulations on the protection of human subjects.

The Committee is satisfied that your provisions for protecting the rights and welfare of all subjects participating in the research are adequate. Your project is renewed and this approval will expire on $9 / 29 / 2013$. Please note the following policies:

4. If the project continues beyond the expiration date, the investigator needs to submit a Continuing Review Report form (available in the Office of Research \& Strategic Partnerships) two months before the expiration date.

5. To add this project's continuing review to the HSRRC/IRB meeting agenda, please refer to the HSRRC/IRB meeting schedule. Submit the report, and the required number of copies, by the submission deadline that is approximately two months before the project's expiration date. The HSRRC/IRB needs two months to do a continuing review of the project, so it is extremely important that you meet the committee's submission deadline.

6. If this project finishes before the expiration date, please contact the HSRRC administrator so that the file can be closed and records updated. It is the investigator's responsibility to keep the approval status current. If the project's approval expires while the project is active, the investigator must complete new application and submit it for a new HSRRC review. In addition, any data collected after the expiration date cannot be used in the research. Please don't let this happen!

If you have questions or concerns, please contact the HSRRC in Research and Strategic 
Partnerships (RSP), (503) 725-2243. 